TATIANA LOPES OMETTO

MONITORAMENTO DO VÍRUS DO OESTE DO NILO NO BRASIL

Tese apresentada ao Programa de PósGraduação Interunidades em Biotecnologia USP/Instituto Butantan/IPT, para a obtenção do Título de Doutor em Ciências. 
TATIANA LOPES OMETTO

\section{MONITORAMENTO DO VÍRUS DO OESTE DO NILO NO BRASIL}

Tese apresentada ao Programa de PósGraduação Interunidades em Biotecnologia USP/Instituto Butantan/IPT, para a obtenção do Título de Doutor em Ciências.

Área de concentração: Biotecnologia

Orientador: Prof. Dr. Edison Luiz Durigon

Versão corrigida. A versão original eletrônica encontra-se disponível tanto na Biblioteca do ICB quanto na Biblioteca Digital de Teses e Dissertações da USP (BDTD). 
DADOS DE CATALOGAÇÃO NA PUBLICAÇÃO (CIP)

Serviço de Biblioteca e Informação Biomédica do

Instituto de Ciências Biomédicas da Universidade de São Paulo

(c) reprodução total

Ometto, Tatiana Lopes.

Monitoramento do Vírus do Oeste do Nilo no Brasil / Tatiana Lopes Ometto. -- São Paulo, 2013.

Orientador: Prof. Dr. Edison Luiz Durigon.

Tese (Doutorado) - Universidade de São Paulo. Instituto de Ciências Biomédicas. Programa de Pós-Graduação Interunidades em Biotecnologia USP/IPT/Instituto Butantan. Área de concentração: Biotecnologia. Linha de pesquisa: Vírus emergentes em animais silvestres.

Versão do título para o inglês: Surveillance of West Nile virus in Brazil.

$\begin{array}{lll}\text { 1. Vírus do Nilo Ocidental 2. Sorologia 3. Biologia molecular } & \end{array}$

4. Brasil 5. Equídeos 6. Aves migratórias I. Durigon, Prof. Dr. Edison Luiz II. Universidade de São Paulo. Instituto de Ciências Biomédicas. Programa de Pós-Graduação Interunidades em Biotecnologia USP/IPT/Instituto Butantan III. Título. 
Candidato(a): $\quad$ Tatiana Lopes Ometto.

Título da Tese: $\quad$ Monitoramento do Vírus do Oeste do Nilo no Brasil.

Orientador(a): $\quad$ Prof. Dr. Edison Luiz Durigon.

A Comissão Julgadora dos trabalhos de Defesa da Tese de Doutorado, em sessão pública realizada a considerou
( ) Aprovado(a)
( ) Reprovado(a)

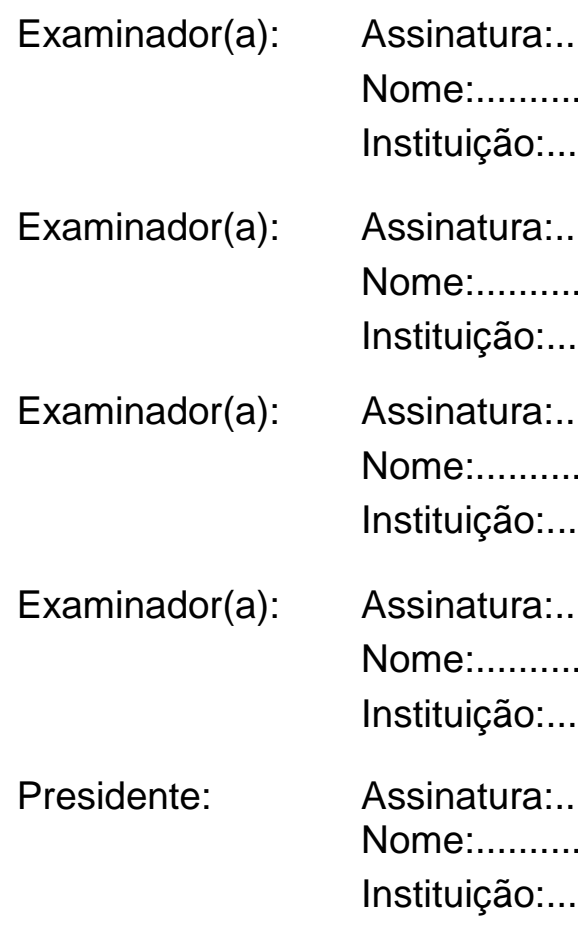


Cidade Universitária "Armando de Salles Oliveira"

\section{Certificado}

Certificamos que o protocolo registrado sob $\mathrm{n}^{\circ} \mathbf{1 0 5}$ nas fls. 74 do livro 02 para uso de animais em experimentação, sob a responsabilidade do $\operatorname{Prof}(a) \operatorname{Dr}(\mathrm{a})$ Edison Luiz Durigon, Coordenador(a) da Linha de pesquisa Monitoramento de aves silvestres e eqüinos do virus da febre do oeste no Nilo no Brasil pela técnica de real-time PCR do qual participou(aram) o(s) alunos Tatiana Lopes Ometto, Jansen de Araújo, Renata Ferreira Hurtado e os pesquisadores Severino Mendes de Azevedo Junior, Joaquim Lointo Brando e Maria Virginia Petry, está de acordo com os Principios Éticos de Experimentação Animal adotado pela Sociedade Brasileira de Ciência de Animais de Laboratório (SBCAL) e foi aprovado pela COMISSÃO DE ÉTICA EM EXPERIMENTAÇÃO ANIMAL (CEEA) em 13.08.09, com validade de 3 anos.

São Paulo, 13 de agosto de 2009.

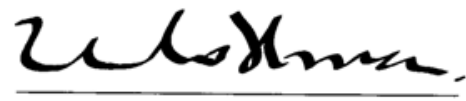

Prof.Dr.WOTHAN TAVARES DE LIMA Coordenador CEEA - ICB/USP

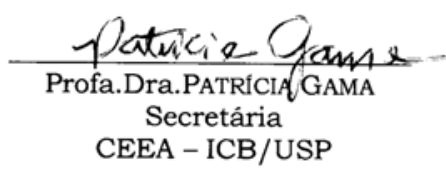


À minha mãe, que onde quer que esteja, sei que observa de longe os passos que dou, independente do caminho que eles me levarão.

Ao meu pai, que me apoiou, me confortou e me impulsionou em todos os momentos de fraqueza, de exaustão, de indecisão, não deixando faltar inspiração para terminar este trabalho e querer continuar seguindo sempre em frente. 


\section{AGRADECIMENTOS}

Como não poderia deixar de ser, gostaria primeiramente de agradecer enormemente ao meu pai, por ter acreditado em mim e dado todo o suporte físico e emocional para que eu conseguisse chegar até este momento. Obrigada por tudo pai, você foi fundamental! Amo você!

Obrigada mãe, por ter feito com que me tornasse quem sou, pois sei que sou seu reflexo! Fico extremamente feliz em ouvir das pessoas, que cada vez me pareço mais com você... pois mesmo não tendo sua presença há muitos anos, essa comparação só me dá mais certeza de que você está sempre comigo, a cada dia, a cada hora, a cada minuto, a cada segundo dos meus dias, fazendo com que eu me torne uma mulher da qual você pudesse se orgulhar. Te amo mãe! Muitas saudades....sempre!!!!

Agradeço muito à minha família, pois cada um ao seu modo, me auxiliou para que eu chegasse onde estou. Meu irmão e minha cunhada que estão sempre ao meu lado, inclusive na correção e discussão deste trabalho e me deram a maior felicidade que é minha afilhada Sara, que está para nascer a qualquer momento enquanto escrevo essas palavras; à Tia Lucia, que mesmo com seus 95 anos, ainda me ensina muito sobre a vida e sobre ter coragem e força de vontade. É a prova de que independente da idade, devemos manter nossa garra. Grande exemplo de pessoa e mulher, que sigo à risca como inspiração, para um dia tentar ser ao menos parte do que ela é para todos da família. À Tia Dalgisa e Paulo, que realizaram o árduo trabalho de verificar esta escrita junto ao meu pai, por dias a fio e muitas horas de telefone e Skype, mas principalmente por que sempre me apoiaram e incentivaram a seguir em novos desafios e nos momentos de cansaço, estavam sempre prontos, com um sorriso enorme, uma mesa farta de distrações deliciosas e as cabeças repletas de discussões que certamente solidificaram meu raciocínio científico. À Tia Vera e à Mariangela, pelo alívio e tranquilidade passados em todas as vezes que busquei conforto nas palavras sempre carinhosas, as quais me impulsionavam a seguir em frente. À Sandra, Allan, Thales, Cris, Ademar, Gui e Joana, por todos os momentos de alegria dadas as conquistas de cada um de nós e pelos momentos de simples lazer, pois cada momento desses só me deu mais certeza do quanto amo esta família. Ao Tio Darlan, Tia Vanda, Ana, Carlos, Bárbara, Thaís e Darlanzinho, que apesar do pouco contato pela distância ou pela correria do dia-a-dia, sempre que nos encontramos são momentos deliciosos e de grande aprendizado!

À minha nova família Araujo, que desde sempre me receberam de braços abertos e cheios de amor, alegria e carinho. Me aceitaram como sou e sempre, me agradam, mesmo ficando tentada com tantos doces maravilhosos, está lá, sempre em algum lugar um mimo sem açúcar guardado especialmente para mim, obrigada pela sempre gentileza! Compartilham cada novo passo juntos e estão sempre prontos para apoiar e comemorar as conquistas de cada um. Obrigada Shijiro, Roseli, Janiele e especialmente à Janine e ao João que também estão na expectativa do nascimento do meu sobrinho, João Guilherme, que logo logo estará aqui conosco, nos trazendo ainda mais alegria. Obrigada por tudo, amo vocês!

Ao meu orientador Prof. Dr. Edison Luiz Durigon, que desde Rondônia, em 2002, me cativou com suas palavras entusiásticas e me envolveu na carreira acadêmica, provando que vale a pena fazer pesquisa no Brasil, apesar de todas as dificuldades. Me mostrou muitos caminhos a seguir, confiou em meus passos e minhas decisões, sempre abrindo portas para meu crescimento profissional. Sei que sempre repito isto em todas as oportunidades que posso, 
então, que fique aqui registrado, obrigada por todas as oportunidades e obrigada pela confiança, sempre! Tudo isso fez com que me tornasse uma profissional melhor!

Às minhas grandes amigas Juliana e Karina, que estiveram sempre comigo em todos os momentos de aflições e comemorações, e que com amizade, carinho e amor, me mostravam que valia a pena continuar sempre em frente! Obrigada por escutarem meus desabafos e minhas alegrias, mas obrigada principalmente por essa amizade incomparável. Amo vocês duas!

À minha comadre Silvana, que surpreendentemente me presenteou confiando seu bem mais precioso à mim, meu afilhado Renato. Que muitas vezes me distraiu nos momentos de descanso na elaboração deste estudo, com muita alegria a cada nova palavra, a cada novo passo. Obrigada pela confiança, e pode ter certeza que farei tudo que estiver ao meu alcance para cuidar do nosso filhote! Amo vocês dois!

A todos os amigos do Externato, do Objetivo, da UMC, da rua, da PG, do ABC, dos peixes palhaços, do SAE e de muitos outros locais que provavelmente devo estar me esquecendo, obrigada pela compressão por tantas ausências em casamentos, festas e encontros, decorrentes das viagens realizadas para que este estudo fosse possível. Obrigada pela compressão e amizade!

À todos os colegas do laboratório Jansen, Luciano, Marina, Renata, Carla, Danielle, Angélica, Gustavo, Zé, Thaís, Joana, Raquel, Érika, por todo o suporte tanto na realização dos testes laboratoriais, na preparação das viagens, nas escritas dos trabalhos e pelos momentos de alegria, distração e discussão. Se não fosse pela colaboração de vocês, com certeza este trabalho não teria conseguido ser realizado da forma que foi! Obrigada!

A todos da USP que indiretamente auxiliaram no desenvolvimento deste estudo, Luis, Carol, Dyana, Cláudia, Felipe, Danila, Fábio, Lilia, Camila e Priscila; Pessoal da secretaria da Biotec, Fábia, Marcos e Eliane, pessoal de apoio do ICB, Zezinho e equipe da lavagem e esterilização. Obrigada por todo o suporte!

Ao Prof. Dr. Levi (Dudi), por mil motivos! Nem tenho como pontuar quão fundamental foi todo o seu auxílio durante o desenvolvimento deste trabalho. Desde os controles, a colaboração no CII, as muitas discussões, até a escrita do nosso artigo... nem tenho como agradecer tantos ensinamentos. Muitíssimo obrigada por tudo!!!!! E muito obrigada ainda por proporcionar à toda minha família a alegria de descobrirmos que teríamos um casal de sobrinhos, desde o início da gravidez das minhas cunhadas. Em nome de todos, obrigada mais uma vez!

Ao Prof. Dr. Jerez, que no início do projeto me aceitou alegremente como aluna e auxiliou em todo o desenrolar inicial deste trabalho, além de se disponibilizar prontamente para discutir e reformular as idéias que surgiam para que este estudo fosse possível. Fica aqui meu muito obrigado por toda compressão e ensinamentos.

Às amigas Ana Paula e Andréia, pelas discussões mercadológicas que não me deixaram esquecer o quanto aprendi e me diverti enquanto trabalhávamos juntas com marketing e imensamente obrigada pelo auxílio na revisão desta escrita. 
Aos colegas do grupo do CRA-SP, que compreenderam minhas ausências para o desenvolvimento deste projeto, por me receberem de braços abertos e possibilitarem que eu entrasse no mundo da administração hospitalar para aprender com a expertise de vocês!

À todos do CIRAD em Guadeloupe, Thierry, Rosalie, Jennifer, Valerie, Ludovic, Nathalie, Damien, Cathy, Laure, Amal, Willy, Izabel e Marion, tanto pelos ensinamentos laboratoriais e epidemiológicos, quanto pela hospitalidade em Guadeloupe. Aqui fica um agradecimento especial ao Nicolas Gaidet do CIRAD - Montpellier pelo contato, pois proporcionou minha ida a Guadeloupe. Obrigada!

Ao Prof. Robert Lanciotti pela confirmação das amostras suspeitas.

Ao pessoal do CEMAVE, Isaac e Patrícia, pelos convites para as expedições em parceria. Ao Elivan, Ari, Eduardo, Raquel e aos outros profissionais que também fizeram parte das expedições como Márcio Effe, Alexandre, Leandro Bugoni, Flávia, Guilherme e Janete, obrigada pelo coleguismo e pelo excelente trabalho de campo que pudemos realizar juntos inúmeras vezes.

Ao Prof. Dr. Severino e sua equipe, por toda a sua disposição e força para que as expedições acontecessem e por todo os ensinamentos em manejo e migração das aves.

Ao Prof. Dr. Daniel, pelo interesse e confiança na parceria com nosso laboratório, por ter prontamente disponibilizado um grande banco amostral de soros, além de arquitetar toda a nossa ida para o Pantanal e principalmente pela amizade e apoio!! Muito Obrigada!

Ao Prof. Dr. João Batista de Pinho, por passar muito do seu conhecimento ornitológico para esta biomédica que mal sabia diferenciar uma ave e hoje já identifica algumas. A todos da sua equipe Liandre, Ursula, Dirceu e Letícia, que prontamente nos auxiliaram no campo e na identificação das aves pantaneiras.

À Prof. Virgínia, Angelo e Elisa, pelo empenho na coleta das amostras que fazem parte deste estudo.

A toda a equipe do Laboratório CII que prontamente me auxiliou na realização dos testes moleculares automatizados e principalmente ao Me. Marcelo Plaisant, por toda a ajuda, discussões e tentativas que fizemos durante esses anos para procurar o WNV no Brasil.

À Dra. Helenice, Dra. Maria do Carmo e Dra. Eliana do Instituto Biológico, que disponibilizaram as amostras de SNC de equídeos para acrescentarmos ao desenho amostral deste estudo, bem como à equipe da Virologia Vegetal que muito me ensinou sobre diagnósticos virais e principalmente biologia molecular.

À equipe do Laboratório da Prof. Dra. Dolares do ICB, principalmente à Dra. Telma, que realizou toda a cultura celular e sempre foi extremamente solícita e engajada para que conseguíssemos o isolamento viral.

À Guacyara que disponibilizou as amostras de equídeos provenientes de sua dissertação de mestrado. 
Ao Marcelo Nardi e Alessandra Nava pela disponibilização das amostras de equídeos do Pontal do Paranapanema coletadas com apoio do Instituto de Pesquisas Ecológicas -IPÊ.

À FAPESP pelo apoio financeiro fundamental para a realização deste estudo.

E por fim, aqui em lugar de destaque, agradeço enormemente ao meu marido, Dr. Jansen de Araujo, que desde a escrita do projeto para a realização deste estudo, já se dispôs a ajudar pronta e efetivamente, tanto na padronização da técnica quanto nas discussões. Não mediu esforços para que conseguíssemos realizar todos os testes propostos deste trabalho, mesmo quando eu insistia em voltar ao laboratório em uma sexta feira à 1:00 da manhã para ver um resultado ou até quando ficava nas madrugadas e nos finais de semana escrevendo esta tese. Obrigada, obrigada, obrigada! Seu apoio profissional foi essencial para que eu conseguisse dar até mesmo meu primeiro passo para a realização deste estudo, mas, nem se compara com o apoio pessoal que me deu ao longo dos nossos 8 anos e meio que estamos juntos. Obrigada pelo seu amor, seu companheirismo, sua compreensão, seu carinho, suas risadas, sua opinião, sua fé e sua crença em mim! Eu te amo meu amor, meu marido! E que possamos continuar a viver e pesquisar juntos por muitos anos ainda! Obrigada por fazer a diferença! 
"Cantar e cantar e cantar, a beleza de ser um eterno aprendiz!"

Gonzaguinha 


\section{RESUMO}

OMETTO, T. Monitoramento do vírus do Oeste do Nilo no Brasil. 2013. 162 f. Tese (Doutorado em Biotecnologia) - Instituto de Ciências Biomédicas, Universidade de São Paulo, São Paulo, 2013.

O Vírus do Nilo Ocidental, do inglês West Nile virus (WNV) é um patógeno emergente que é amplamente distribuído na América do Norte e Central. A recente introdução na América do Sul chamou a atenção para a propagação do WNV em países Sul-americanos. O ciclo de transmissão envolve mosquitos, pássaros, cavalos e seres humanos. A avaliação sorológica realizada nestes estudos foi composta por 678 soros de equídeos e 478 soros de aves, realizada por meio do ensaio ELISA de bloqueio específico para WNV e somente as amostras com resultados positivos foram confirmadas por testes de neutralização por redução em placas (PRNTs). A análise molecular foi realizada em soros de 1.241 equídeos saudáveis e em 63 macerados de cérebros de equídeos que morreram de encefalite e obtiveram resultados previamente negativos para outros patógenos. Também testamos swabs de 3.445 aves pelo método molecular, além de amostras de 24 morcegos e 11 onças. As amostras analisadas foram coletadas em diferentes biomas do Brasil. Identificamos pelo ELISA anticorpos para o WNV em treze equídeos e cinco pássaros, e o teste de $\mathrm{PRNT}_{90}$ confirmou positividade para o WNV em quatro amostras de equídeos coletadas em 2009 em uma região entre a Amazônia e o Pantanal. Nenhuma das amostras de aves positivas pelo ELISA foram confirmadas por PRNT $_{90}$. Das 4.784 amostras testadas por RT-PCR, apenas duas apresentaram resultados positivos para a detecção, sendo uma ave residente na região do Pantanal e um anatídeo na região do Maranhão, respectivamente. A circulação do WNV é confirmada pela presente pesquisa em larga escala, mesmo na ausência da detecção de casos clínicos.

Palavras-chave: Vírus do Nilo Ocidental. Sorologia. Biologia molecular. Brasil. Equídeos. Aves migratórias. 


\begin{abstract}
OMETTO, T. Surveillance of West Nile virus in Brazil. 2013. 162 p. Ph. D. Thesis (Biotechnology) - Instituto de Ciências Biomédicas, Universidade de São Paulo, São Paulo, 2013.

West Nile virus (WNV) is an emergent pathogen that is widely distributed in North and Central America. The recent introduction in South America has focused attention on the spread of WNV across Southern American countries. The transmission network involves mosquitoes, birds, horses and humans. The serological evaluation of sera from 678 equids and 478 birds was performed using a WNV-specific blocking ELISA, and only the positive results were confirmed by plaque reduction neutralisation tests (PRNTs). Molecular analysis was performed on sera from 1241 healthy equids and on 63 macerates of brains from equids that died of encephalitis and had previously tested negative for other pathogens. We also tested swabs from 3.445 birds, 24 bats and 11 phanteras. The samples analysed were collected in different biomes of Brazil. We identified WNV antibodies by ELISA in thirteen equids and five birds, and $\mathrm{PRNT}_{90}$ confirmed WNV positivity in four equid samples collected in 2009 in an area between the Amazon and the Pantanal. None of the ELISA positive bird samples were confirmed by $\mathrm{PRNT}_{90}$. Of the 4.784 samples tested by RT-PCR, only two were positive for the detection, a resident bird in the Pantanal region and a duck in the region of Maranhão, respectively. WNV circulation is confirmed by this large scale survey even in the absence of detection of clinical cases.
\end{abstract}

Keywords: West Nile virus. Serology. Molecular biology. Brazil. Equids. Migratory birds. 


\section{LISTA DE ILUSTRAÇÕES}

Figura 1 - Ciclo natural do vírus do Oeste do Nilo........................................................ 28

Figura 2 - Rotas migratórias de aves no continente americano ..................................... 30

Figura 3 - Circulação do WNV no mundo entre 1960 e 2004 ........................................... 35

Figura 4 - Foco de microscopia eletrônica de um representante da família

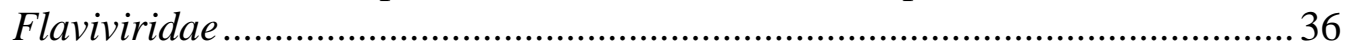

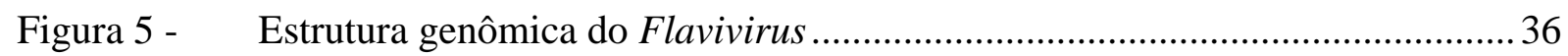

Figura 6 - Número de casos de WNV em cavalos antes da vacinação e um ano após a

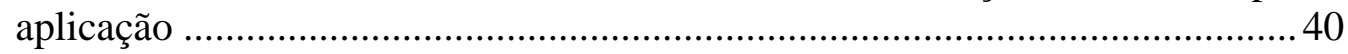

Figura 7 - Locais da América Latina e Caribe com descrição de WNV, entre 2001 e

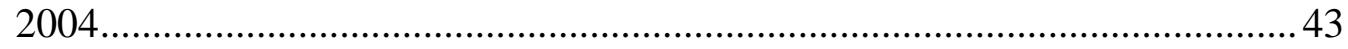

Figura 8 - Viremia do WNV comparativa para 10 ordem de aves .................................. 44

Figura 9 - Dispersão do WNV nas Américas entre 1999 e 2007.......................................45

Figura 10 - Esquema de tempo em relação à produção de anticorpos depois da infecção por Flavivirus e os protocolos diagnósticos para as flaviviroses ...........................48

Figura 11 - (I) Ilustração das rotas migratórias de aves do Sul para o Norte das Américas e (II) do Norte para o Sul ................................................................................53

Figura 12 - Rotas continentais e intercontinentais de aves migratórias................................53

Figura 13 - Principais rotas migratórias de aves a partir do primeiro foco de WNV reconhecido na América ................................................................................. 54

Figura 14 - Mapa de localização das amostras coletadas na Ilha de Canelas .......................55

Figura 15 - Disposição das redes de neblina em duas localizações diferentes na Ilha de Canelas: (I) praia e (II) borda da mata .......................................................55

Figura 16 - (I) Dr. Nicolas Gaidet em campo e (II) base de apoio ...................................56

Figura 17 - Principais espécies capturadas na região: (I) Calidris pusilla e (II) Limnodromus griseus ..............................................................................56

Figura 18 - Mapa de localização das amostras coletadas na Ilha da Coroa do Avião.........57

Figura 19 - (I) Bando de aves em revoada e (II) criotubo com fezes coletadas na areia . .58

Figura 20 - Mapa de localização das amostras coletadas em Glória .58 
Figura 21 - Principal espécie capturada na região: Zonotrichia capensis

Figura 22 - $\quad$ Mapa de localização das amostras coletadas no PNLP...................................59

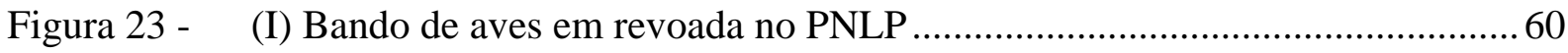

Figura 24 - (I) Os dois funcionários do parque carregando os equipamentos da armadilha artesanal e (II) o resultado da coleta por este método de captura

Figura 25 - (I) Bando homogêneo de aves em revoada e (II) coleta de material de fezes frescas

Figura 26 - (I) a seca nos primeiros dias de expedição, (II) perda de material de acampamento em decorrência dos fortes ventos, (III) a consequente cheia com inundação da lagoa e submersão das redes de neblina e (IV) perda do material de captura.

Figura 27 - Principais espécies capturadas na região: (I) Haematopus palliatus e (II) Rynchops niger

Figura 28 - (I) Aves silvestre atravessando a tela de proteção da granja e (II) Larus dominicanus moribundo à beira mar.

Figura 29 - Mapa de localização das amostras coletadas no Rio Grande do Sul 64

Figura 30 - Principais espécies capturada na região: (I) Sicalis flaveola e (II) Puffinus gravis

Figura 31 - Mapa de localização do CETAS.

Figura 32 - Ave em recuperação no CETAS - SC . 65

Figura 33 - Mapa de localização das amostras coletadas na Ilha de Fernando de Noronha

Figura 34 - Principal espécie capturada na região: rabo-de-palha-de-bico-vermelho (Phaethon aethereus)

Figura 35 - $\quad$ Mapa de localização das amostras coletadas nas Reentrâncias Maranhenses ..67

Figura 36 - Senhora trazendo seu animal de estimação (Gallinula chloropus) para a coleta de amostra

Figura 37 - Principais espécies capturadas na região: (I) Arenaria interpres e (II) Dendrocygna autumnalis

Figura 38 - Mapa de localização das amostras coletadas no Pantanal. 68

Figura 39 - (I) Rede de neblina armada e (II) coleta de material das aves no campo .69 
Figura 40 - Principais espécies capturadas na região: (I) Certhiaxis cinnamomeus e (II) Gallus gallus

Figura 41 - Locais na Argentina onde foram reportados os isolamentos do WNV de cavalos

Figura 42 - Mapa de localização das amostras coletadas em Monte Negro 71

Figura 43 - (I) Imagem da região de Monte Negro - RO e (II) base de apoio do ICB

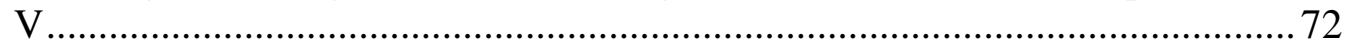

Figura 44 - $\quad$ Mapa de localização das amostras coletas no Pontal do Paranapanema............72

Figura 45 - (I) Imagem da região do Pontal do Paranapanema - SP e (II) base de apoio do

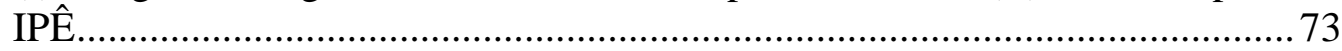

Figura 46 - $\quad$ Mapa de localização das amostras coletadas no estado do Mato Grosso ......... 74

Figura 47 - (I) Imagem da região do Pirizal em Poconé - MT e (II) base de apoio do

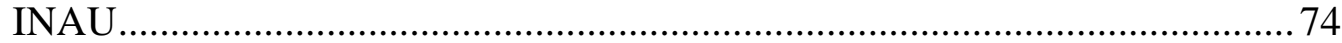

Figura 48 - (I) Região pantaneira e (II) coleta sanguínea de equino ...................................75

Figura 49 - Mapa com a distribuição de biomas e estados brasileiros com locais das coletas

Figura 50 - (I) Casa abandonada, (II) morcegos alojados no teto do local, (III) manejo e identificação e (IV) coleta sanguínea............................................................ 76

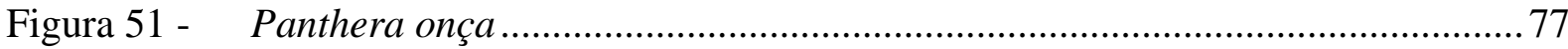

Figura 52 - (I) Carros utilizados nas expedições, (II) estrutura ornitológica para biometria e identificação, e (III) acampamento .............................................................. 78

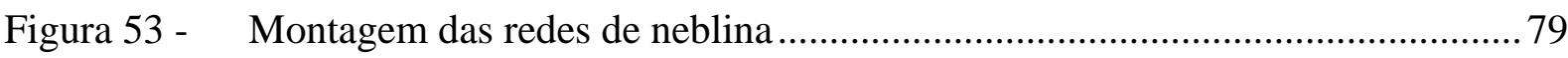

Figura 54 - $\quad$ Ave presa na rede de neblina …....................................................................

Figura 55 - (I) Biometria e (II) identificação da ave........................................................ 80

Figura 56 - Carga viral no soro (a), swab oral (b) e penas (c), dias após a infecção estimada por NS2a-specific $r R T$-PCR em corvos juvenis inoculados experimentalmente com as estirpes Is98 (barras pretas) e Fr2000 (barras brancas) de WNV .........81

Figura 57 - (I) Coleta de swab cloacal e (II) swab traqueal............................................. 81

Figura 58 - (I) Coleta sanguínea em animais de médio porte, (II) coleta sanguínea de animais de pequeno porte 
Figura 59 - (I) Amostras armazenadas em nitrogênio líquido no campo e (II) soltura da ave

Figura 60 - (I) trabalho laboratorial noturno para separação de alíquota de soro e (II) amostra de sangue com as fases de soro e coágulo evidenciadas

Figura 61 - (I) Placa de identificação do Laboratório do CIRAD, (II) laboratório de sorologia, (III) amostras recebidas em Guadeloupe e (IV) procedimento........ 83

Figura 62 - Esquema de distribuição das amostras em placa 84

Figura 63 - (I) Distribuição das amostras e (II) lavagem da placa em lavadora automática ......

Figura 64 - (I) Bloqueio da reação e (II) leitura da absorbância em leitor de ELISA . 87

Figura 65 - Desenho esquemático do laboratório Klaus Eberhard Stewien, Biosafety Level $3+\left(\mathrm{BSL}^{+}\right)$

Figura 66 - (I)Visão Panorâmica do laboratório, (II) trabalho com amostras suspeitas, (III) máquina de real-time PCR e (IV) Pass-through para passagem de amostras .. 90

Figura 67 - Sequencia nucleotídica do genoma do WNV representando a localização dos primers (azul) e sonda (verde)

Figura 68 - Sala de biologia molecular do Laboratório CII. 94

Figura 69 - (I) automação de triagem de amostras, (II) automação para extração e detecção molecular, (III) amostras identificadas com código de barras e (IV) automação em funcionamento.

Figura 70 - (I) Transporte da máquina de real-time, (II) procedimento de extração do material genético, (III) preparação de reagentes para o teste molecular, (IV) equipamento de real-time $R T-P C R$, (V) reação em andamento e (VI) uso dos equipamentos em campo.

Figura 71 - Tapete celular do controle negativo de células VERO .98

Figura 72 - Gráfico composto por resultados apresentados pelo grupo de 435 equídeos do estado do Mato Grosso.....

Figura 73 - Gráfico composto por resultados apresentados pelo grupo de 41 amostras de aves da espécie Arenaria interpres.....

Figura 74 - Locais e data das coletas de equídeos com demonstração dos biomas brasileiros e resultados sorológicos obtidos 108

Figura 75 - Análise eletroforética em gel de agarose 2,0\%, dos produtos amplificados utilizando primers de 16S. Peso - 1.000 Kb DNA Ladder (Thermo Scientific Fermentas) 
Figura 76 - Curva de amplificação dos controles positivos. O eixo x representa o número de ciclos e o eixo y, representa a quantidade de fluorescência emitida.

Figura 77 - Amplificação dos controles positivos puros e em pool: A- controle 1 (forte) puro; B- controle 10 (médio) puro; C- controle 1 (forte) pool; D- controle 10 (médio) pool; E- controle 9 (fraco) puro; F- controle 9 (fraco) pool.

Figura 78 - Gráfico de one-step real-time RT-PCR das amostras do PNLP, com curva de amplificação do controle positivo

Figura 79 - Gráfico de one-step real-time RT-PCR das amostras de aves do Maranhão com curva de amplificação do controle positivo e da amostra MA242......

Figura 80 - Gráfico composto por resultado do ELISA, do grupo com total de 84 amostras de aves da espécie Dendrocygna sp, sendo a amostra MA 232 em destaque acima do grupo base de resultados 112

Figura 81 - (I) Gráfico do resultado do controle positivo do kit, (II) gráfico do resultado do controle positivo do estudo, (III) gráfico de amostra negativa. A curva azul representa o controle interno da reação e a curva vermelha, a detecção ou não do vírus nos controles e amostras 113

Figura 82 - Relatório de resultados com (I) amostras de cérebros - não reativos; (II) controle positivo de WNV - reativo; (III) controle negativo - não reativo ..... 113

Figura 83 - Tela de resultado do one-step real-time $R T$ - PCR em campo, sendo que a curva vermelha no final do ciclo representa a detecção viral do controle positivo utilizado.

Figura 84 - Curva de amplificação de one-step real-time RT-PCR em campo da amostra suspeita......

Figura 85 - Foto do efeito citopático da cultura celular da amostra PAN02 116

Figura 86 - Análise eletroforética em gel de agarose 2,0\%, dos produtos amplificados. Aamplificação utilizando primers segundo FULOP et al., 1993. B- amplificação utilizando primers segundo MOUREAU et al., 2007 - modificado. Peso - 1.000 Kb DNA Ladder (Thermo Scientific - Fermentas). Os círculos indicam os fragmentos amplificados de 350 e 270 pb respectivamente. Como controle negativo, foi utilizado água $(\mathrm{C}-)$. Para controle positivo $(\mathrm{C}+)$ foram utilizados amostras de cultura de vírus da Dengue, Febre amarela e soro inativado do Vírus do Oeste do Nilo 116 


\section{LISTA DE TABELAS}

Tabela 1 - Evolução anual do número de casos da doença e óbitos nos EUA desde 1999.

Tabela 2 - Lista das aves encontradas na América provenientes da Eurásia, nas quais foram encontradas evidências de contato com WNV

Tabela 3 - Resumo do desenho amostral de aves e dados geográficos 70

Tabela 4 - Resumo do desenho amostral de equídeos e dados geográficos. .75

Tabela 5 - Descrição dos primers e sonda utilizados na reação de one-step real-time RTPCR

Tabela 6 - Controles positivos utilizados com as respectivas cargas virais 92

Tabela 7 - Descrição dos primers de $16 \mathrm{~S}$ utilizados na reação 93

Tabela 8 - Descrição dos primers utilizados na reação 101

Tabela 9 - Descrição dos primers utilizados na reação 102

Tabela 10 - Descrição dos primers utilizados na reação 102

Tabela 11 - Amostras positivas para ELISA 105

Tabela 12 - Resultados do ELISA e PRNT. Em vermelho, as quatro amostras positivas por ELISA e confirmadas por PRNT

Tabela 13 - Resultado sorológico da amostra MA232.

Tabela 14 - Análise das sequências de nucleotídeos dos controles positivos sequenciados. $\mathrm{O}$ alinhamento foi realizado pelo programa BioEdit Sequence Alignment Editor versão 6.0.7. 117 


\section{LISTA DE ABREVIATURAS E SIGLAS}

ADEPARA - Agência de Defesa Agropecuária do estado do Pará

BA - Bahia

BLAST - Basic Local Alignment Search Tool

BSA - albumina bovina

BSL3 $^{+}$- Biosafety Level 3+

cDNA - DNA complementar

CDC - Centers for Disease Control and Prevention

CEMAVE - Centro Nacional de Pesquisa e Conservação de Aves Silvestres

CETAS - Centro de Triagem de Animais Silvestres

CII - Centro de Imunologia e Imunoterapia

CIRAD - contrôle des maladies animales exotiques et émergente

DNA - ácido desoxirribonucléico

EDTA - Ethylenediamine tetraacetic acid

ELISA - Enzyme Linked Immuno Sorbent Assay

EPI - Equipamento de Proteção Individual

EUA - Estado Unidos da América

Exo - Exonuclease

F350 - Ford 350

FAMEV - Faculdade de Medicina Veterinária

FFRPE - Universidade Federal Rural de Pernambuco

FMV - Faculdade de Medicina Veterinária

HI - inibição da hemaglutinação

HRP - Horseradish Peroxidase

IB - Instituto Biológico

ICB - Instituto de Ciências Biomédicas

ICMBio - Instituto Chico Mendes de Conservação da Biodiversidade

IMT - Instituto de Medicina Tropical

INAU - Instituto Nacional de Áreas Úmidas

IPÊ - Instituto de Pesquisa Ecológicas

KUN - Kunjin vírus

MA - Maranhão

MAB - anticorpo monoclonal 
MAPA - Ministério da Agricultura Pecuária e Abastecimento

MME - meio mínimo essencial

MT - Mato Grosso

NB3 - Nível de Biossegurança 3

NCBI - National Center for Biotechnology Information

NCBI - National Center for Biotechnology Information

NY - New York

PA - Pará

PBS - solução salina

PE - Pernambuco

PEMD - Parque Estadual Morro do Diabo

PNLP - Parque Nacional da Lagoa do Peixe

PRNT - Plaque Reduction Neutralization Test

RK - Rabbit Kidney cells

RNA - ácido ribonucléico

RO - Rondônia

rRNA - RNA ribossomal

RS - Rio Grande do Sul

RT-PCR - reverse transcription-polymerase chain reaction

SAP - Shrimp Alkaline Phosphatase

$\mathrm{SC}$ - Santa Catarina

SFB - soro fetal bovino

SLEV - Saint Louis encephalitis virus

SNC - Sistema Nervoso Central

SP - São Paulo

UFMT - Universidade Federal do Mato Grosso

UNISINOS - Universidade do Vale do Rio dos Sinos

URSS - União das Repúblicas Socialistas Soviéticas

USDA - United States

USP - Universidade de São Paulo

VERO - Green Monkey Kidney Cell

WNV - West Nile Vírus 


\section{LISTA DE SÍMBOLOS}

$\%$ - porcentagem

${ }^{\circ} \mathrm{C}$ - graus célsius

$<-$ menor

$>$ - maior

$1 / 3$ - um terço

$1 / 8$ - um oitavo

$1^{\mathrm{a}}$ - primeira

$25 \mathrm{x}-25$ vezes

$2^{\circ}$ - segunda

3' - 5' - três linha - cinco linha

a.C. - antes de Cristo

Ag - antígeno

C- - controle negativo

$\mathrm{C}+$ - controle positivo

cDNA - DNA complementar

Ct - cycle threshold

dNTP - deoxyribonucleotide triphosphates

DO - densidade óptica

Dr (a) - Doutor (a)

E - envelope

$\mathrm{G}$ - grama

G1 - glicoproteína 1

$\mathrm{H}_{2} \mathrm{O}$ - água

$\mathrm{H}_{2} \mathrm{O}_{2}$ - peróxido de hidrogénio

IgG - imunoglobulina $\mathrm{G}$

IgM - imunoglobulina $\mathrm{M}$

$\mathrm{Kb}$ - Kilobase

$\mathrm{Km}$ - quilómetro

$\mathrm{Km}^{2}$ - Quilómetro quadrado

M - Mol

Me. - Mestre

$\mathrm{MgCL}_{2}$ - cloreto de magnésio 
min - minuto

$\mathrm{mL}$ - mililitro

$\mathrm{mM}$ - milimolar

$\mathrm{Na}_{2} \mathrm{CO}_{3}$ - Carbonato de sódio

$\mathrm{NaHCO}_{3}$ - Bicarbonato de sódio

$\mathrm{Nm}$ - nanômetro

NS1 - região não estrutural

P/Mol - pico Mol

$\mathrm{pb}$ - pares de base

$\mathrm{pH}$ - potencial de hidrogênio

$\mathrm{PhD}$ - Philosophiae Doctor

$\mathrm{PRNT}_{50}$ - plaque reduction neutralization test, $50 \%$ reduction in number of plaques

$\mathrm{PRNT}_{90}$ - plaque reduction neutralization test, $90 \%$ reduction in number of plaques

Prof (a) - Professor (a)

rpm - rotaçãoo por minuto

Tm - Temperatura de melting

TMB _ Tétramethylbenzidine

UTR - região não codificadora

$\mu \mathrm{L}$ - microlitro 


\section{SUMÁRIO}

1 INTRODUÇÃ

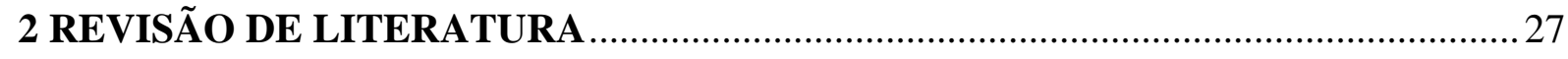

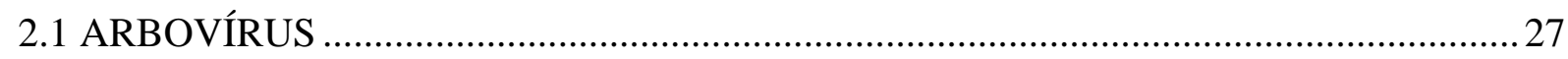

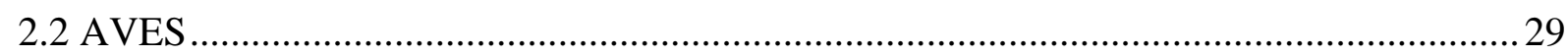

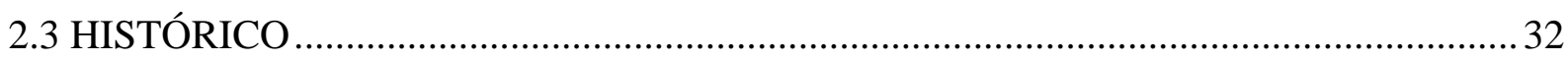

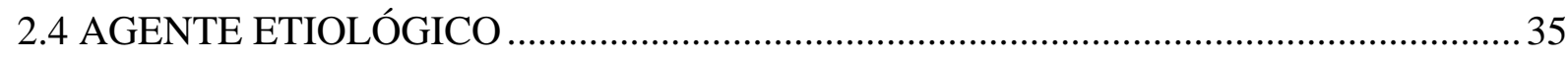

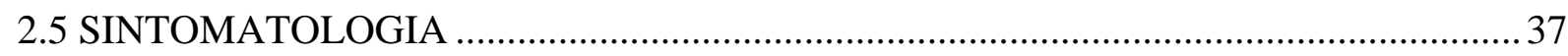

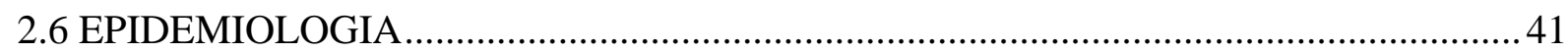

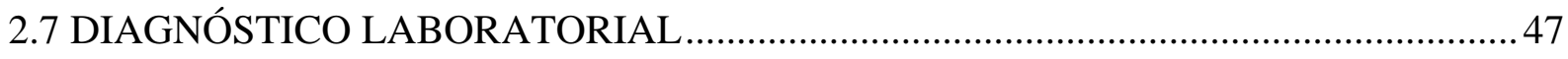

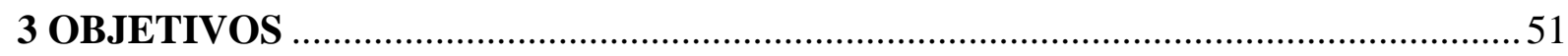

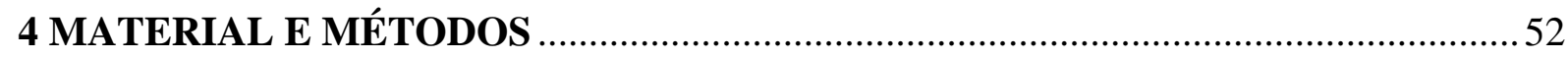

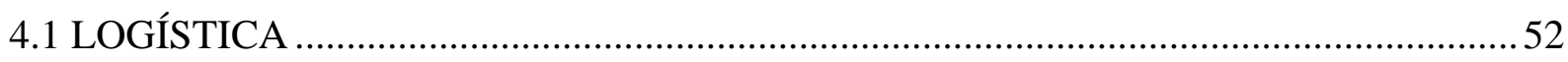

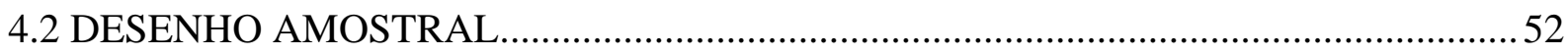

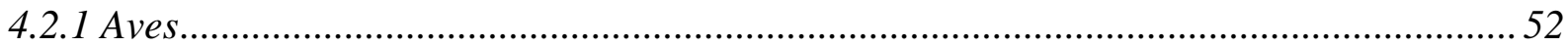

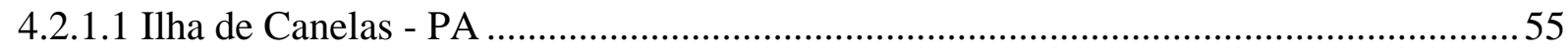

4.2.1.2 Ilha da Coroa do Avião - PE...............................................................................57

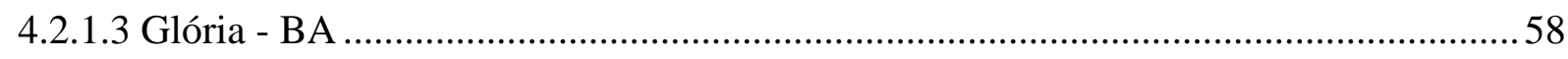

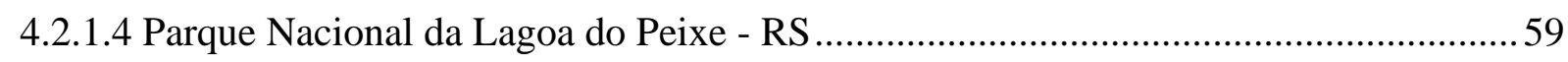

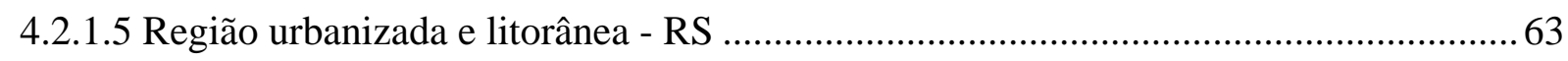

4.2.1.6 Centro de triagem de animais silvestres - SC ............................................................65

4.2.1.7 Ilha de Fernando de Noronha - PE .........................................................................6 66

4.2.1.8 Reentrâncias Maranhenses - MA..............................................................................67

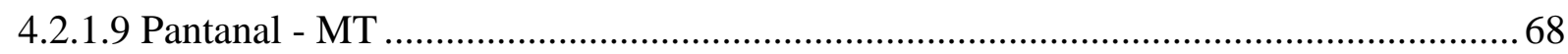

4.2.1.10 Resumo amostral de aves ............................................................................... 70

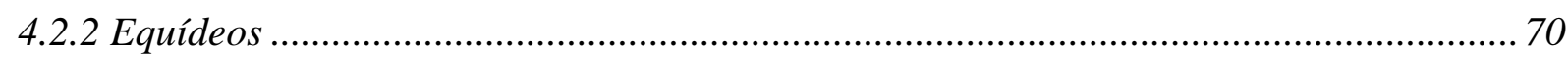

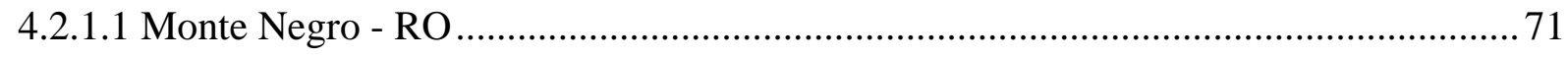

4.2.1.2 Pontal do Paranapanema - SP ................................................................................ 72

4.2.1.3 Instituto Biológico - SP ........................................................................................73

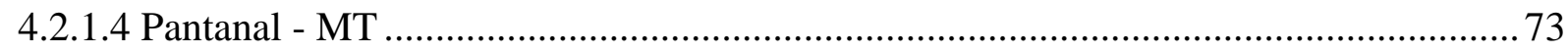

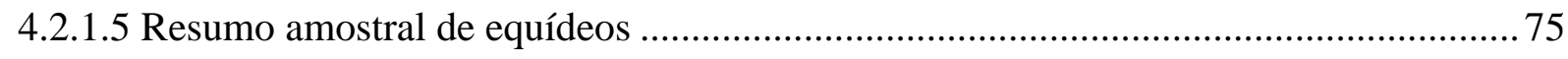

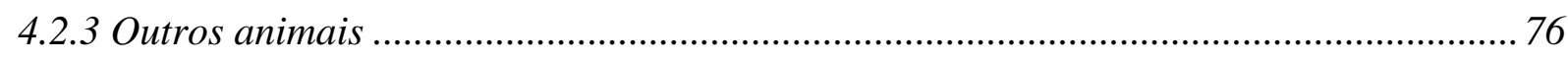




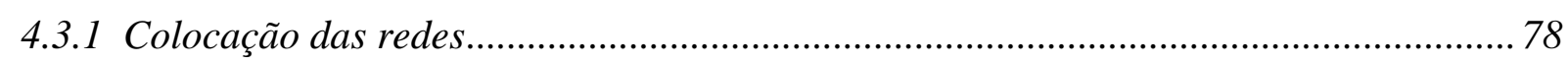

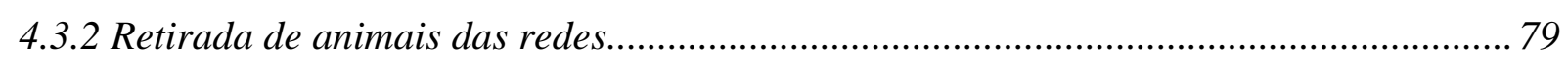

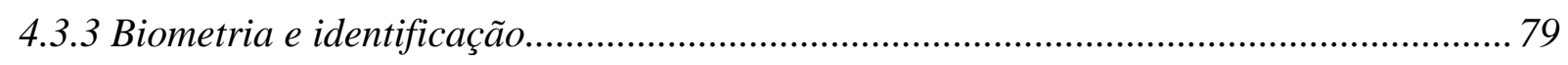

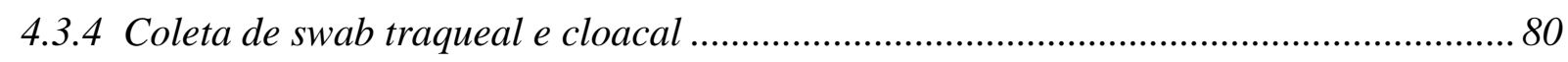

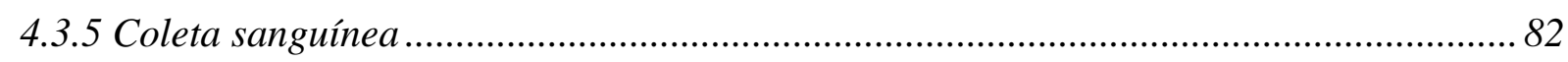

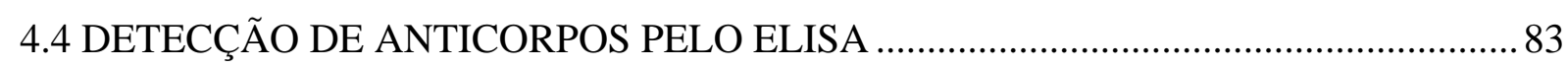

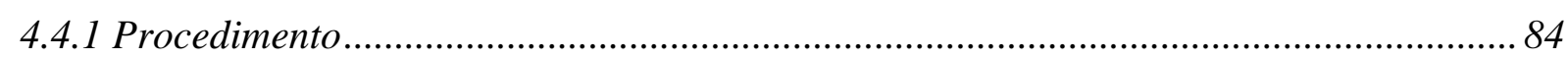

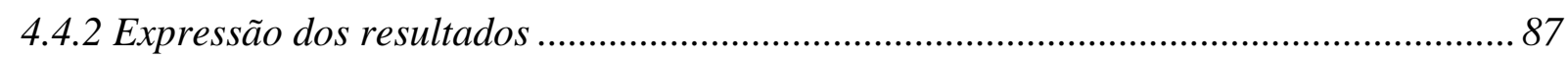

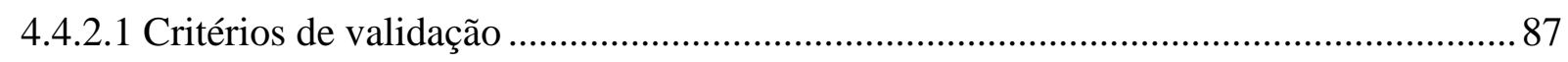

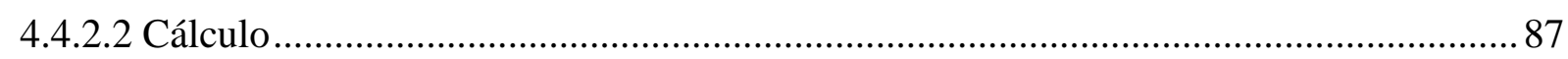

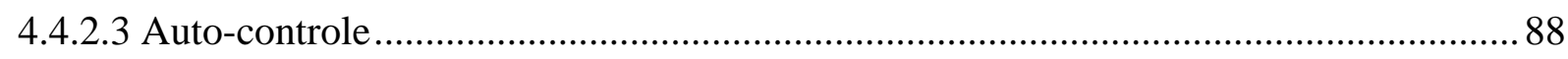

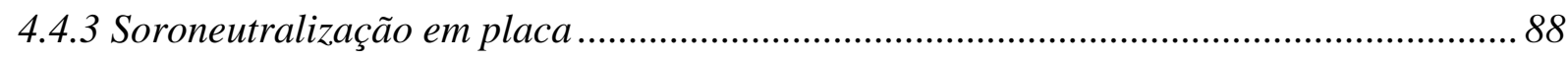

4.5 DETECÇÃO MOLECULAR DO WNV EM AMOSTRAS DE EQUÍDEOS E AVES....88

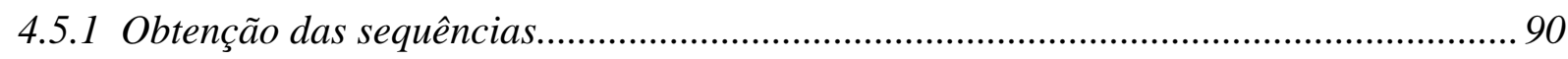

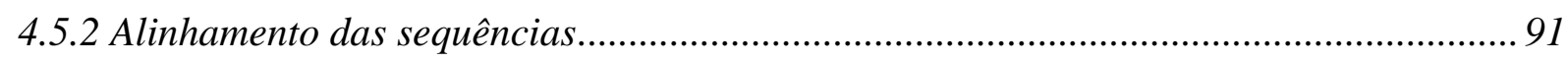

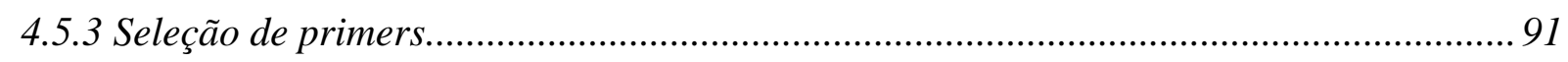

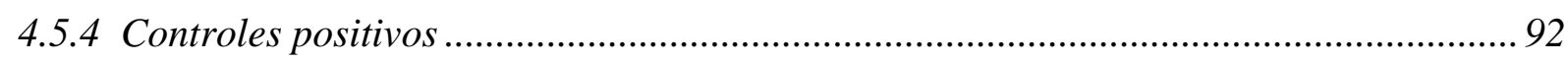

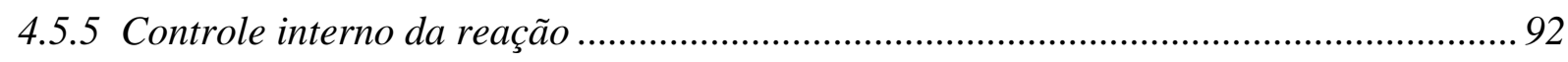

4.5.6 Extração do material genético ...................................................................................... 93

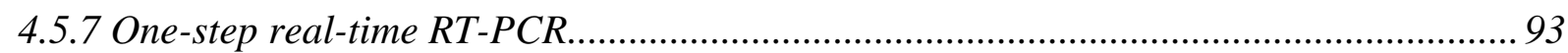

4.6 DETECÇÃO MOLECULAR AUTOMATIZADA DO WNV EM AMOSTRAS DE

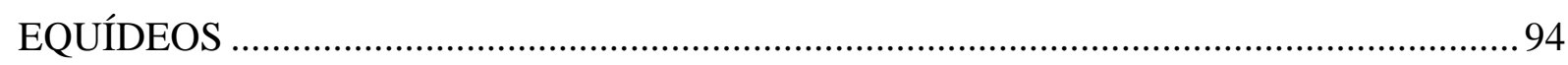

4.7 DETECÇÃO MOLECULAR DO WNV EM CAMPO .................................................. 96

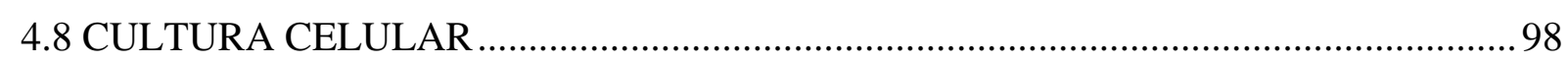

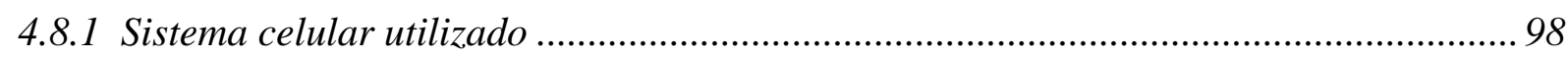

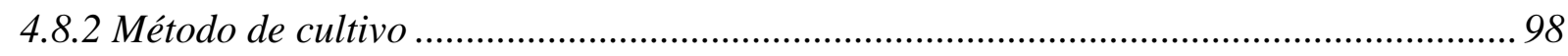

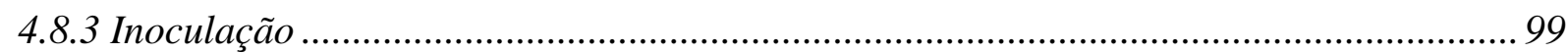

4.9 ANÁLISE DAS AMOSTRAS SUSPEITAS POR BIOLOGIA MOLECULAR E

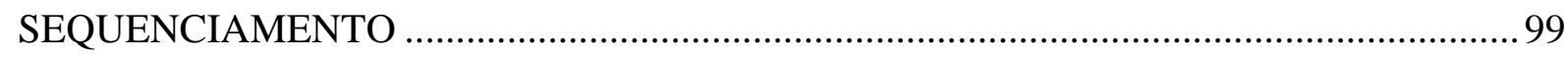

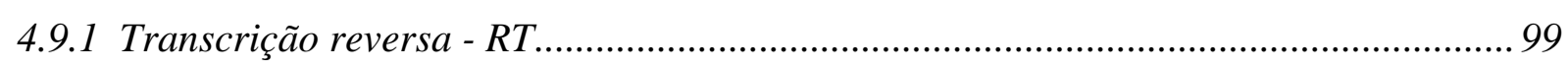

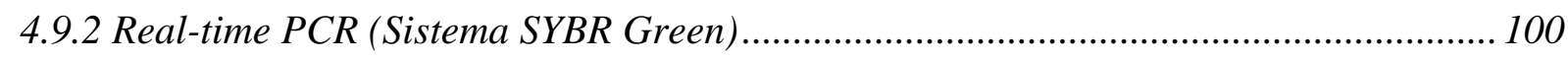

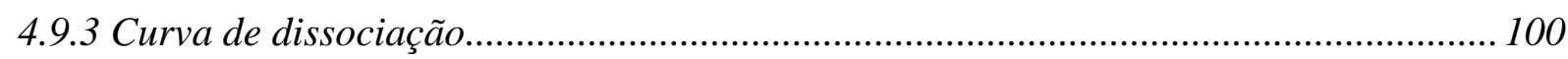

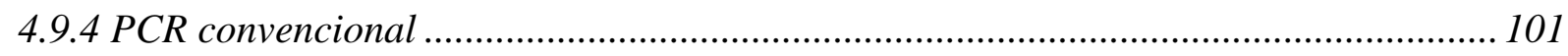


4.9.4.1 PCR com primers Moureau - modificado ............................................................. 101

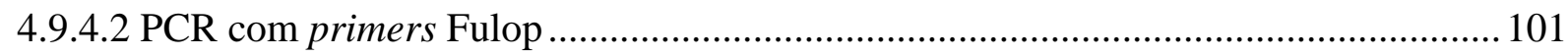

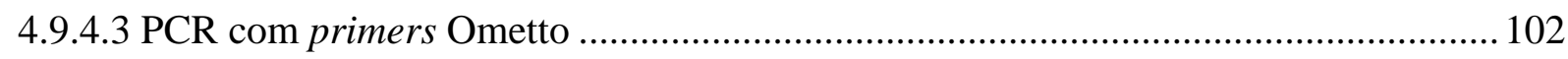

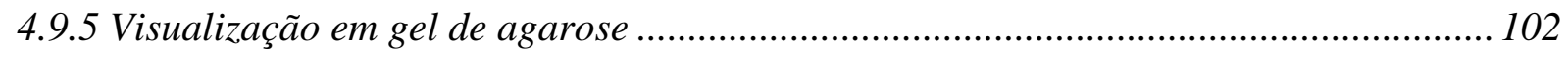

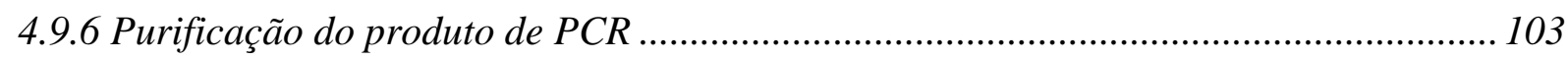

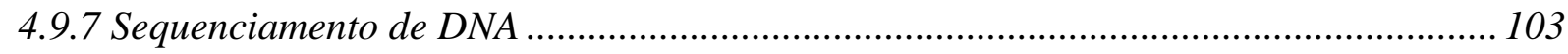

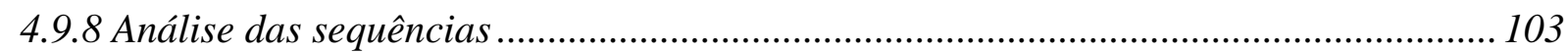

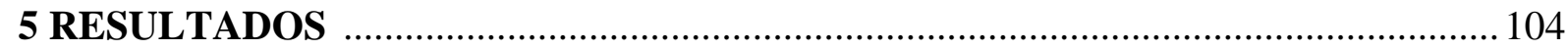

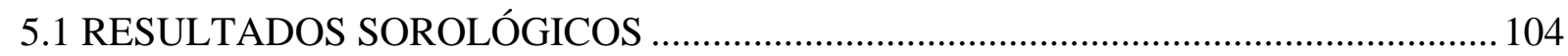

5.2 RESULTADOS DA BIOLOGIA MOLECULAR NO LABORATÓRIO NB3+ ............ 108

5.2.1 Avaliação da técnica de extração e PCR ........................................................................ 108

5.3 RESULTADOS DA BIOLOGIA MOLECULAR AUTOMATIZADA........................... 112

5.4 RESULTADOS DA BIOLOGIA MOLECULAR EM CAMPO .................................... 114

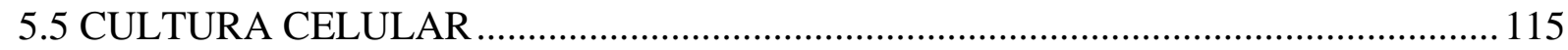

5.6 CONFIRMAÇÃO DAS AMOSTRAS SUSPEITAS …............................................. 116

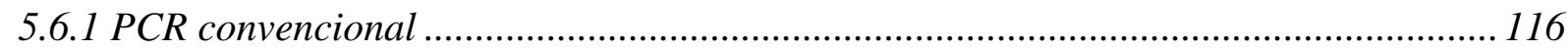

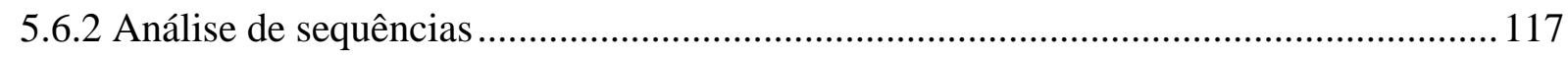

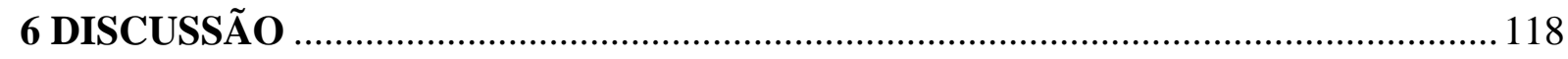

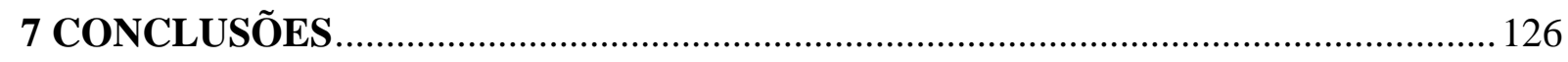

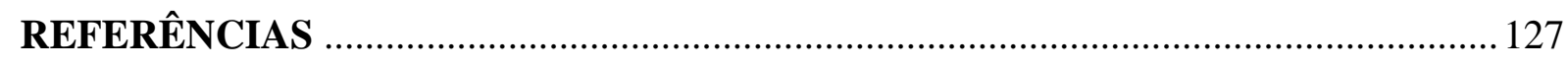

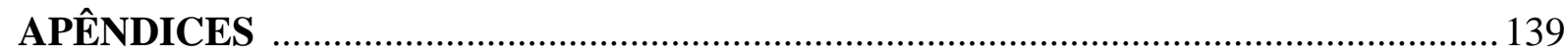

APÊNDICE A - Tabela de amostras coletadas ............................................................... 139

APÊNDICE B - Artigo científico publicado .................................................................... 154 


\section{INTRODUÇÃO}

Arboviroses são doenças de etiologia viral veiculadas entre vertebrados por artrópodes hematófagos. A maior parte dos arbovírus pertencem a cinco diferentes famílias, Reoviridae, Rhabdoviridae, Flaviviridae, Bunyaviridae e Togaviridae, sendo que as três últimas possuem representantes que causam doenças em humanos, como a Febre da Dengue, do Mayaro, do Oropouche, a Doença do Oeste do Nilo, entre outras (BROOKS; BUTEL; MORSE, 2000).

O Brasil, país com mais de $1 / 3$ de seu território coberto por florestas e ecossistemas naturais, proporciona condições favoráveis para a existência de diferentes arbovírus, sendo que o Catálogo Internacional de Arbovírus registrou em 2001, mais de 500 diferentes espécies e destas, pelo menos 187 foram isoladas no Brasil (FIGUEIREDO, 2007).

Atualmente, dentre as arboviroses emergentes nas Américas, a de maior importância em saúde pública e econômica é a Febre do vírus do Oeste do Nilo, termo originário do inglês West Nile virus (WNV). Seu agente é um vírus da família Flaviridae, pertencente ao complexo das encefalites japonesas. Em 1937 em Uganda, país africano situado a oeste do rio Nilo, foi descrito o primeiro caso humano, fazendo com que a encefalite ganhasse este nome.

Tornou-se uma ameaça para o Ocidente quando foi descoberto o primeiro caso da doença em território americano, em Nova York em 1999. A partir deste acontecimento o vírus vem realizando trajetória ao sul do continente aproximando-se do Brasil, onde ainda não foi descrito nenhum caso clínico. Já existem relatos de cavalos e aves com sorologia positiva para o vírus na Colômbia em 2005 (MATTAR et al., 2005), na Venezuela em 2007 (BOSCH et al., 2007) e Argentina em 2008 (ADRIÁN DIAZ et al., 2008), que também obteve o primeiro isolamento do WNV na América do Sul, provenientes de três cavalos, em 2006 (MORALES et al., 2006). Recentemente achados sorológicos em equinos no Brasil tem sido demonstrados (MELANDRI et al., 2012; PAUVOLID-CORRÊA et al., 2011), com resultados semelhantes ao deste estudo (OMETTO et al., 2013), mas até o momento não existem confirmações do isolamento viral no país.

Tendo em vista a quantidade de casos de doenças emergentes e re-emergentes relatados nas últimas décadas no continente sul-americano e os atuais casos do vírus na América do Sul, propusemos neste estudo avaliar a ocorrência do vírus do Oeste do Nilo em seus reservatórios e hospedeiros finais animais e sua variabilidade genética em áreas do Brasil.

O monitoramento do WNV no Brasil se faz necessário para um melhor conhecimento da atual situação epidemiológica brasileira, principalmente nas regiões onde ocorra o contato de animais silvestres residentes com as aves migratórias, possíveis carreadoras do WNV. 


\section{REVISÃO DE LITERATURA}

\subsection{ARBOVÍRUS}

Muito antes da descoberta do mundo microbiano o termo vírus era utilizado para designar qualquer agente capaz de produzir doenças. A palavra é latina e originalmente significava "veneno" ou "fluído venenoso". No início dos estudos da microbiologia, os agentes microbianos, fossem bactérias, fungos ou protozoários, eram chamados indiscriminadamente de "vírus" (STANIER; DOUDOROFF; ADELBERG, 1969).

O termo arbovírus deriva das sílabas iniciais das palavras inglesas "artropod borne viruses" (BROOKS; BUTEL; MORSE, 2000). Os arbovírus são vírus transmitidos por artrópodes (invertebrados com patas articuladas) e representam um grupo ecologicamente bem definido ao qual pertencem diferentes famílias, entre elas: Flaviviridae, Orthobunyaviridae e Togaviridae, que são transmitidos por artrópodes hematófagos de um hospedeiro para outro (BROOKS; BUTEL; MORSE, 2000). Existem mais de 450 arbovírus, e aproximadamente 100 são patógenos humanos, sendo que as principais arboviroses que ocorrem no mundo são a febre amarela, dengue, encefalites, como a Japonesa, de Saint Louis, Equinas do Leste e do Oeste, Venezuelana e a Febre do Oeste do Nilo (TRABULSI; ALTERTHUM, 2005).

Os artrópodes desempenham papel de vetores, quer sejam mecânicos, no qual a transmissão dos vírus é feita mecanicamente de um hospedeiro para o outro, ou biológicos, sendo que parte do ciclo vital ocorre no organismo do artrópode. Os artrópodes também desempenham papel de reservatório por transmitirem verticalmente os agentes infecciosos (TRABULSI; ALTERTHUM, 2005), como ilustrado na figura 1. 


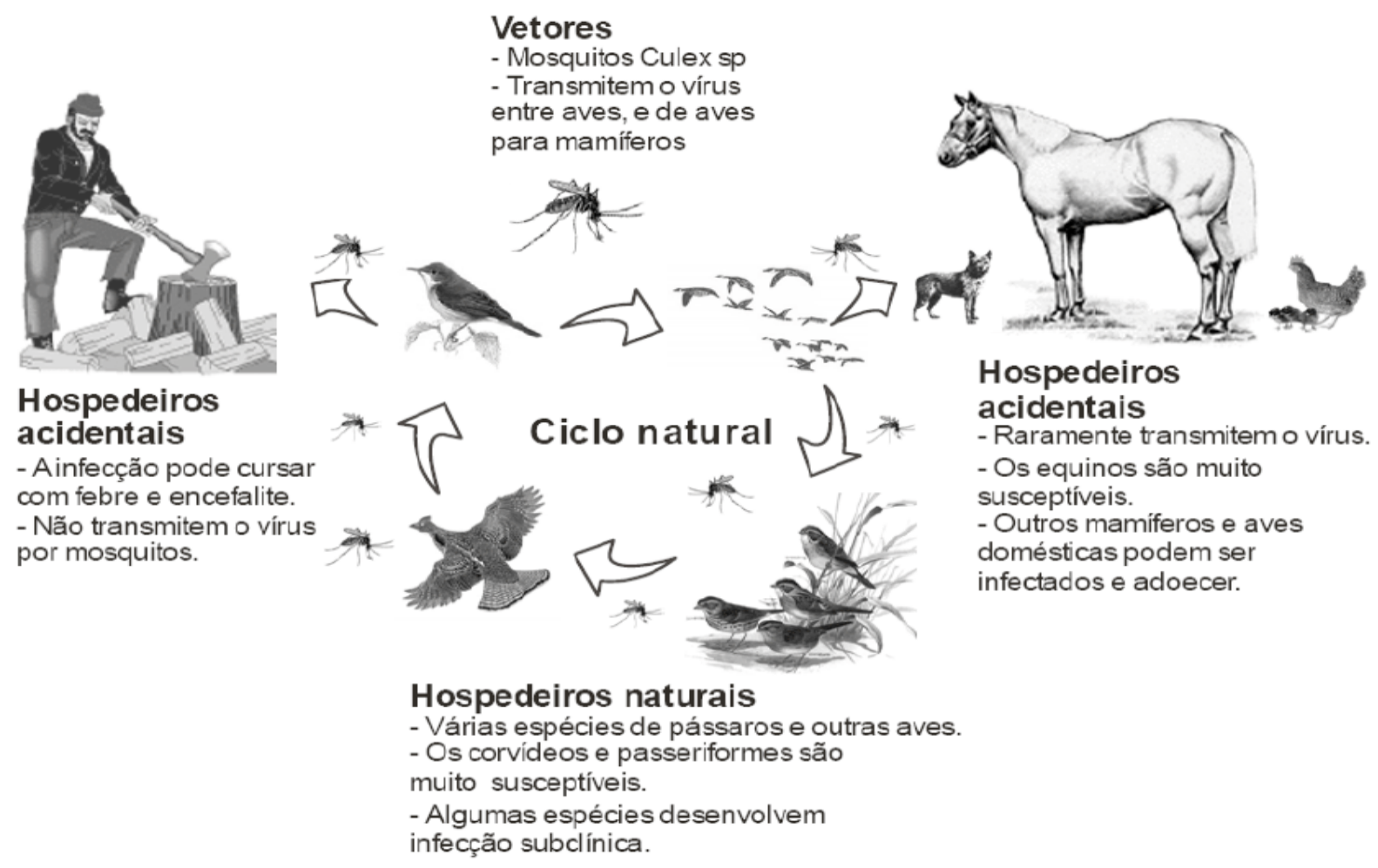

Figura 1 - Ciclo natural do vírus do Oeste do Nilo.

Fonte: (FLORES; WEIBLEN, 2009)

Mosquitos são insetos de distribuição mundial que apresentam importância para a saúde pública por serem vetores de agentes causadores de parasitoses e viroses (FORATTINI, 2002). O mosquito pode adquirir a infecção ao se alimentar do sangue de hospedeiro vertebrado com elevada viremia (GUBLER et al., 2001; KARABATSOS, 1985).

Em viroses transmitidas por mosquitos, os vírus depois de ingeridos infectam as células do tubo digestivo passando às glândulas salivares, onde sofrem replicação e podem através da picada serem transmitidos a um novo hospedeiro. Eles se multiplicam nos tecidos dos artrópodes sem qualquer evidência de doença ou lesão e provocam infecção permanente no vetor (BROOKS; BUTEL; MORSE, 2000). Das arboviroses transmitidas no Brasil, os Flavivirus apresentam destaque por causarem o maior número de infecções e doenças no homem e pela gravidade das doenças que provocam (ROSA et al., 1998) além do fato de que uma vez infectado, o artrópode, após o período de incubação, torna-se apto a transmitir os arbovírus durante toda sua vida e é então considerado um vetor (CORDELLIER; DEGALLIER, 1992).

O Brasil é um país tropical de grande extensão territorial $\left(8.514 .215 \mathrm{~km}^{2}\right)$ e com 185.360.000 habitantes. Mais de 1/3 deste território é recoberto por florestas tropicais ou outros 
ecossistemas naturais com condições ideais para a ocorrência de diversas arboviroses, às quais são mantidas em uma grande variedade de ciclos zoonóticos (FIGUEIREDO, 2007). Além das áreas preservadas por florestas tropicais, o Brasil também possui cidades que abrigam áreas verdes, representadas por parques, que são refúgios para a proteção e conservação da biodiversidade. Em tais áreas ocorre a presença de lagos, fontes e outros locais que podem servir de refúgio para mosquitos que infestam a área urbana, bem como a presença de aves, algumas delas migratórias e também mamíferos, sendo que tais locais são frequentados pela população para atividades de lazer (WHATELY et al., 2008) e podem fazer a ponte de transmissão entre aves infectadas por arbovírus e a população local.

Os hospedeiros introdutórios mais prováveis para a disseminação dos arbovírus são as aves migratórias, isto é reforçado pelo fato de que as grandes epidemias ocorrem durante o final do verão e início do outono, época que coincide com a chegada das aves migratórias e de grandes concentrações de mosquitos (NIR et al., 1967). As aves mantêm uma alta viremia após a infecção experimental e são conhecidamente hospedeiros amplificadores (MCINTOSH; DICKINSON; MCGILLIVRAY, 1969).

\subsection{AVES}

Os pássaros são frequentemente importantes fontes de infecção para mosquitos, que então transmitem a infecção para os equinos, outros animais e o homem, que é um "hospedeiro terminal" (ou seja, acidental no ciclo natural e ineficaz na perpetuação do vírus) para a maior parte dos arbovírus (MERCK, 2001). As aves são os principais reservatórios por apresentarem alta viremia, constituindo fonte de infecção para o vetor (ANVISA, 2007).

A frequência de transmissão de arbovírus para humanos depende da densidade populacional, competência do vetor e fatores ambientais como umidade e temperatura. $\mathrm{O}$ risco de transmissão depende também da distribuição geográfica dos vetores (VASCONCELOS et al., 2001). Os arbovírus são amplamente distribuídos no mundo, dependendo da disponibilidade de hospedeiros e vetores adequados (MERCK, 2001), sendo que normalmente as populações humanas mais afetadas são aquelas localizadas próximas às regiões alagadas, que concentram aves e mosquitos (HUBÁLEK; HALOUZKA, 1999).

Por existirem muitas espécies de aves que desenvolvem rotas migratórias do Norte para o Sul e vice-versa (SICK, 1979), com cerca de cinco bilhões de aves migrantes com representantes de mais de 300 espécies (REED et al., 2003), como demonstra a Figura 2, o potencial de desenvolvimento destas viroses no Brasil é muito amplo. 


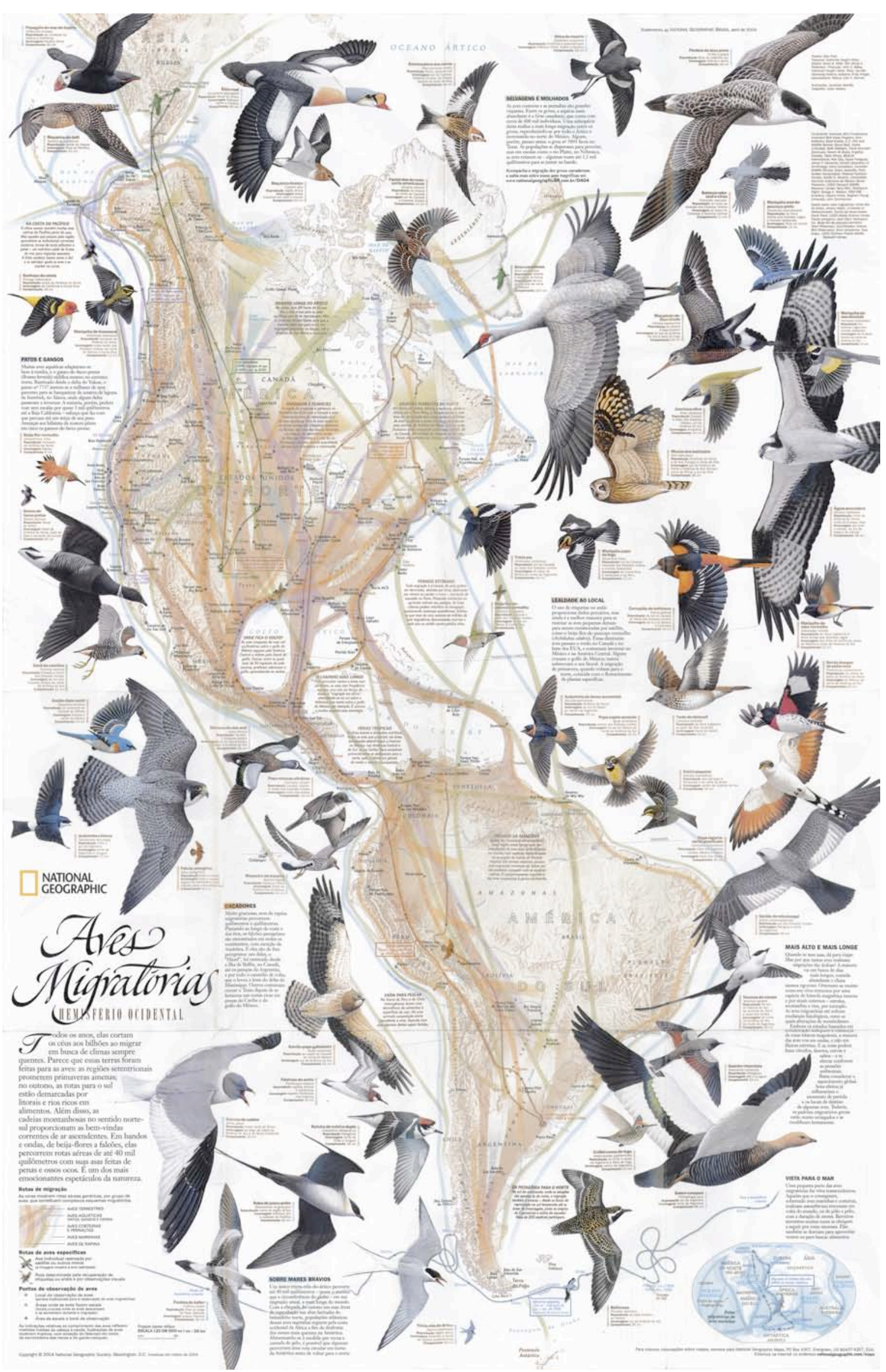

Figura 2 - Rotas migratórias de aves no continente americano.

Fonte: (NATGEO, 2007) 
O Brasil detém o segundo lugar em biodiversidade de aves do planeta (SICK, 1997), sendo que em suas migrações, as aves visitantes atravessam o Brasil ou permanecem aqui durante algumas semanas ou meses. Na maioria dos casos, trata- se de espécies que migram durante o inverno frio dos seus países de origem, mas de um modo geral, o principal ponto de atração não é a temperatura mais elevada dos trópicos e subtrópicos, mas a maior oferta de alimentos nas regiões quentes (SICK, 2001).

Nas migrações de longas distâncias, as aves permanecem por alguns dias nas "staging areas", ou áreas de parada, onde descansam e se alimentam para continuar a migração. Este fato propicia o contato de várias espécies que podem se encontrar ocasionalmente, independente da rota migratória que estão voando, fato importante na discussão da disseminação de doenças infecciosas transmissíveis pelas mesmas (REED et al., 2003). Os deslocamentos sazonais das aves em geral estão associados às migrações para os sítios de reprodução ou alimentação, sendo comum no Brasil os movimentos de aves intercontinentais, regionais, dentre outras. As intercontinentais do inverno do Norte (inverno boreal) e do inverno do Sul (inverno austral) são as mais relevantes para o monitoramento de doenças (SICK, 1983, 1997).

As aves migratórias do inverno boreal (Charadriidae e Scolopacidae) chegam ao Brasil, geralmente em setembro, através das rotas da Amazônia Ocidental, Amazônia Oriental, Brasil Central e costa Atlântica, permanecendo em território nacional até abril (ANTAS, 1984). Nos meses de junho e julho muitas espécies encontram-se em período reprodutivo no Ártico e somente indivíduos jovens, sub-adultos ou adultos que não complementaram o ciclo de muda da penas, permanecem nas áreas de invernada até a próxima temporada de migração (AZEVEDO JÚNIOR et al., 2001).

Áreas de invernada são locais escolhidos pelas aves para pouso, alimentação, muda e ganho de massa corpórea. Os maiores bandos observados no Brasil ocorreram na costa norte e sul e os menores na nordeste e leste (MORRISON; ROSS, 1989). Essas aves migrantes podem ser encontradas em áreas úmidas ao longo do território nacional, entretanto, o litoral do Maranhão, Rio Grande do Norte, Pernambuco, Bahia e Rio Grande do Sul reúnem o maior número de informações publicadas (AZEVEDO JÚNIOR et al., 2001).

A distribuição de uma espécie é geralmente estável, porém, todas as aves realizam algum tipo de deslocamento, longo ou curto, sendo que até mesmo as aves mais sedentárias podem se mover entre 50 a 100 km (HUBÁLEK, 2004). Mas há certa dinâmica natural da fauna, com espécies que espontaneamente alargam sua área de distribuição ou espécies que se retraem, sendo que a intervenção humana pode acelerar o processo. A biodiversidade 
compreende uma diversidade de espécies e ecossistemas. $\mathrm{O}$ aumento da população humana resultou em uma perda da biodiversidade sem precedentes (KEESING et al., 2010), bem como a fragmentação da paisagem urbana, apresentada em um mosaico de diferentes ambientes, com mudanças na vegetação (MENDONÇA; ANJOS, 2005). Como parte desta mudança, alguns habitats e suas comunidades animal e vegetal associadas foram eliminadas, enquanto outras expandiram-se e alguns novos foram criados, ou intencionalmente (parques), ou consequentemente (lixo e águas paradas) (ROBINSON, 2005).

A diversidade biológica promovida por estes ambientes pode representar impacto para a população humana, como por exemplo, os riscos decorrentes da interação ave-mosquitohomem (URBINATTI; SENDACZ; NATAL, 2001), pelo papel que estes artrópodes desempenham na transmissão de doenças ao homem e às aves (MONTES, 2005).

As espécies de aves introduzidas podem ser também nacionais, levadas de um lugar do país, onde existem em estado nativo e transferidas pelo homem à outra região nacional, onde não existiam por natureza. Tais transplantes que a ciência não vê com bons olhos, podem conduzir a uma falsificação da fauna local e colocar em risco as aves residentes deste território (SICK, 2001).

Do ponto de vista científico, a introdução de aves exóticas praticada com maior leviandade por amadores no mundo inteiro, naturalmente sem nenhum estudo prévio de suas implicações, deve ser encarada com grande ceticismo. Nunca se pode prever se um adventício colocará em risco a fauna nativa (SICK, 2001). O transporte de aves vivas, aves silvestres/migratórias, exóticas/de companhia, de caça e esporte, e o comércio de aves domésticas, têm sido implicados como métodos de disseminação importante dos vírus respiratórios e com potencial para serem também disseminadores de outros vírus, como os arbovírus (SHORTRIDGE; BURROWS, 1997).

\subsection{HISTÓRICO}

O Vírus da Febre do Oeste do Nilo ou Vírus do Nilo Ocidental (WNV) inicia sua trajetória na Babilônia com a suposição de que Alexandre, O Grande, tenha morrido por ter contraído a Febre do Oeste do Nilo. Alexandre, O Grande, morreu aos 32 anos, em 323 a.C. na Babilônia, antiga Mesopotâmia, atual Iraque. A causa da morte foi uma febre desconhecida que o acompanhou por duas semanas levando-o a óbito com uma encefalite terminal. Especulou-se na época envenenamento e doenças parasitárias como causa de sua morte, porém, um incidente não considerado nas investigações até então pode ser o guia para a 
descoberta da causa de seu falecimento. $\mathrm{O}$ incidente descrito por Alexandre ocorreu na Babilônia, envolvendo um grupo de corvos com estranhos comportamentos, quando bicavamse uns aos outros e alguns deles caiam mortos em frente à Alexandre. Este comportamento inexplicável é remanescente às aves doentes que também vieram a óbito nos Estados Unidos, semanas antes de ser identificado o primeiro caso humano do WNV na América. Levantando à hipótese de que Alexandre, o Grande, tenha morrido em decorrência de uma encefalite em decorrência da infecção pelo Vírus do Oeste do Nilo (MARR; CALISHER, 2003).

Porém, o WNV foi primeiramente isolado e identificado como um agente patogênico, no sangue de uma mulher natural de Uganda, região a oeste do rio Nilo, no ano de 1937 (SMITHBURN et al., 1940). Durante a década de 1950 estimou-se que $40 \%$ da população humana do delta do Nilo era soro positiva para o vírus (SMITHBURN et al., 1940). A maior epidemia que se tinha notícia ocorreu na Província do Cabo, África do Sul, em 1974 quando aproximadamente 3.000 casos desta virose foram diagnosticados (MCINTOSH et al., 1976).

Muitas linhagens genéticas diferentes deste vírus têm sido identificadas em diversas regiões do globo sendo considerada umas das mais difundidas flaviviroses. Sua distribuição atual estende-se por quase toda a África, Oriente Médio e Eurásia tropical (PEIRIS; AMERASINGHE, 1994) e em 1999 uma linhagem muito semelhante à Israeli foi isolada em um surto ocorrido na América do Norte, mais precisamente em Nova York (LANCIOTTI et al., 1999).

No verão de 1999, médicos do Centro Médico Hospitalar de Nova York observaram vários pacientes com uma doença aguda neurológica de etiologia desconhecida. Em 12 de agosto, um homem de 60 anos foi internado com história de três dias de febre, fraqueza e náuseas. Ele desenvolveu confusão mental, fraqueza muscular, retenção urinária e insuficiência respiratória necessitando de ventilação mecânica. Três dias depois, um homem de 80 anos foi internado com uma história de uma semana de febre, dor de cabeça, diarréia, fraqueza, desenvolveu paralisia flácida e morreu. De 18 de agosto a 02 de setembro do mesmo ano, mais quatro pacientes com início agudo de encefalite e dois com meningite foram admitidos no centro médico. Em investigação posterior, revelou-se que estes pacientes foram infectados com o vírus do Nilo Ocidental, documentando a primeira transmissão autóctone do vírus no Hemisfério Ocidental e anunciando a sua aparição como a principal causa de doenças por arbovírus nos Estados Unidos e Canadá (ASNIS, 2002).

No surto de 1999 na cidade de Nova York, a infecção pelo vírus foi diagnosticada em 62 pessoas doentes, 59 das quais foram hospitalizadas com doença neurológica e sete morreram. Embora os casos humanos fossem documentados apenas na área da cidade de 
Nova York, a mortalidade aviária e equina em decorrência da infecção por WNV foi observada em uma área muito mais ampla, incluindo Connecticut, Nova Jersey, Nova York e Maryland (PETERSEN; HAYES, 2008).

Embora os meios pelos quais o WNV tenha sido introduzido nas Américas nunca foram precisamente determinados, os possíveis mecanismos para a introdução incluem:

- Aves infectadas importadas através do comércio internacional de animais exóticos para os Estados Unidos vindas de Israel ou de áreas próximas ao Oriente Médio;

- Mosquitos e/ou larvas de mosquitos importados acidentalmente de Israel ou em áreas próximas ao Oriente Médio, através de redes de ar ou superfície de transporte dentro de recipientes de carga, produtos agrícolas, veículos ou bens manufaturados;

- Humanos infectados que viajaram entre Israel e os Estados Unidos durante o verão de 1999, no momento de uma epidemia de WNV em Tel Aviv (GUBLER, 2007). O baixo nível de viremia em humanos torna essa possibilidade de introdução menos atraente para muitos, mas tem seus defensores (ARTSOB et al., 2009).

Os meios de importação do vírus para a cidade de Nova York ainda são desconhecidos, no entanto, a hipótese mais aceita é a de que o vírus foi provavelmente introduzido por um mosquito infectado ou pássaro, pois os seres humanos e cavalos desenvolvem viremia insuficiente para infectar eficientemente mosquitos (PETERSEN; HAYES, 2008).

Em julho de 2004 continuou a ser identificada a presença do vírus em mosquitos e aves em Nova York, desencadeando uma série de medidas de vigilância sanitária e epidemiológica, que incluem o controle da população de vetores, a identificação dos reservatórios infectados e o monitoramento da circulação viral (ANVISA, 2007).

Num curto espaço de três anos, a doença disseminou-se em praticamente todo território norte americano, no Canadá e nas ilhas Cayman (ASNIS, 2002; BROOKS; BUTEL; MORSE, 2000; LANCIOTTI et al., 2000), como demonstra a Figura 3. O vírus também foi identificado em diferentes locais na Argentina, isolado do cérebro de três cavalos que morreram com encefalite em fevereiro de 2006, sendo o primeiro caso descrito da encefalite do Oeste do Nilo na América do Sul (MORALES et al., 2006). 


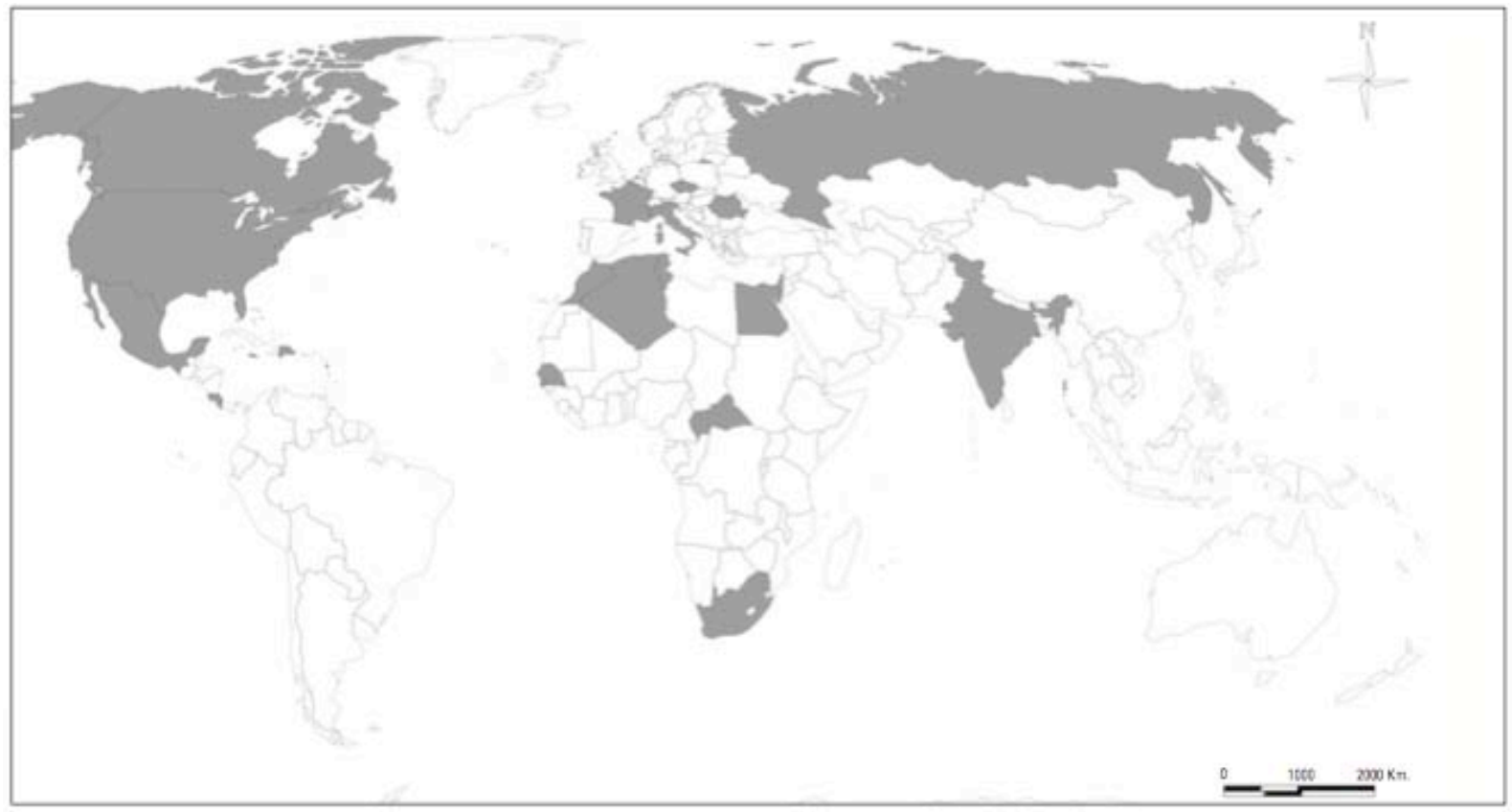

Figura 3 - Circulação do WNV no mundo entre 1960 e 2004. Fonte : (CHEVALIER et al., 2004)

O WNV já foi descrito em humanos, equinos e aves em vários países do Velho Mundo (Europa e África). Recentemente continuam sendo descritos surtos nos Estados Unidos e Canadá. Na América Latina os únicos estudos referem-se a surtos ocorridos no México, El Salvador e Argentina. No Brasil, existem citações de sorologia positiva (MELANDRI et al., 2012; OMETTO et al., 2013; PAUVOLID-CORRÊA et al., 2011), mas não há relatos, segundo pudemos apurar até a escrita deste trabalho, do isolamento viral ou casos descritos de infecção pelo vírus no Brasil.

\subsection{AGENTE ETIOLÓGICO}

O WNV faz parte da família Flaviviridae, possui genoma de RNA de fita simples e sentido positivo, com $10,7 \mathrm{~kb}$ de tamanho e simetria icosaédrica, com demonstra a Figura 4 . O vírus da febre amarela e o vírus da dengue também são exemplos importantes de agentes etiológicos desta família (BROOKS; BUTEL; MORSE, 2000; VASCONCELOS et al., 2001). 


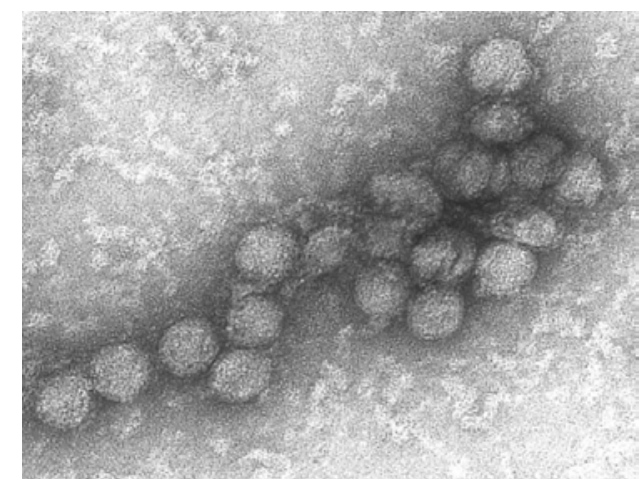

Figura 4 - Foco de microscopia eletrônica de um representante da família Flaviviridae. Fonte: (VACCINENEWSDAILY, 2013)

Os vírus da família Flaviviridae possuem núcleo formado por uma ribonucleoproteina esférica, envolvido por um envelope lipoproteico com pequenas projeções na superfície. Este envelope protege o genoma das nucleases celulares (TRENT; QURESHI, 1971).

A poliproteína codificadora é processada para produzir três proteínas estruturais (capsídeo, pré-membrana e envelope) e sete proteínas não estruturais (NS1, NS2A, NS2B, NS3, NS4A, NS4B e NS5) (RICE et al., 1985). As proteínas não estruturais são codificadas logo após as estruturais e participam de processos de replicação viral e modulação na permeabilidade de membrana, dentre outros. As proteínas NS1, NS3 e NS5 são grandes e altamente conservadas. Já as proteínas NS2A, NS2B, NS4A e NS4B são menores e de característica hidrofóbica (LINDENBACH; RICE, 2003). As regiões não-codificadoras (NCR) 3' e 5' do genoma do WNV possuem 94 e 580 nucleotídeos respectivamente (BRINTON, 1986), como demonstra a figura 5.

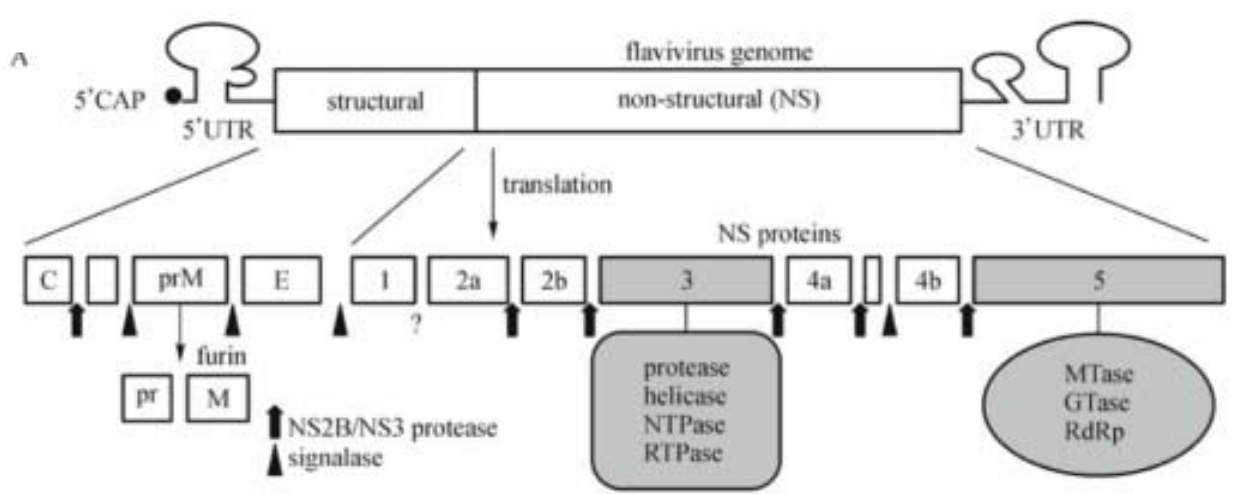

Figura 5 - Estrutura genômica do Flavivirus.

Fonte: (LIU et al., 2010)

Estudos filogenéticos de sequências de ácidos nucléicos que correspondem a uma região de 255 pb do gene da glicoproteína $\mathrm{E}$ de estirpes isoladas do WNV em diferentes regiões geográficas, demonstram que os isolados segregam duas grandes linhagens genéticas 
divergentes (LANCIOTTI et al., 2002) e vários subclados ou clusters (CHARREL et al., 2003; LANCIOTTI et al., 2000). A Linhagem 1 é composta por estirpes com uma ampla distribuição geográfica que vai do oeste da África até o Oriente Médio, Europa Oriental, América do Norte e Austrália. Esta linhagem inclui estirpes virais com grande homologia de sequência de nucleotídeos, que representam os recentes surtos em humanos, cavalos e pássaros. A linhagem 1 pode ser subdividida em pelo menos três subtipos e contém estirpes da Europa, Oriente Médio, Ásia, África e América e apresenta grupos diferentes, incluindo: (i) as mais recentes variedades de vírus israelenses e americanos coletados entre 1997 e 2000, (ii) as estirpes isoladas na Europa e Rússia, entre 1996 e 2000 (Romênia/1996-7, Rússia/1999 e França/2000) (CHARREL et al., 2003) e (iii) as duas estirpes estreitamente relacionadas ao vírus na Itália entre 1998 e 2008 (MONACO et al., 2010). Os recentes surtos graves associados com os seres humanos e doenças aviárias têm sido causadas por um subconjunto de estirpes da linhagem 1. Em contraste, a linhagem 2 parece ser menos virulenta para os seres humanos, uma vez que tenham sido isoladas a partir de casos assintomáticos ou leves, ou mesmo durante a busca de outros agentes patogênicos (MONINI et al., 2010).

\subsection{SINTOMATOLOGIA}

A patogenicidade do WNV é muito similar àquela exibida por outras flaviviroses (NATHANSON N., 1980). Os registros existentes reportam uma infecção persistente seguida de um processo inflamatório sub-agudo degenerativo do sistema nervoso central (SNC) de macacos (POGODINA et al., 1983).

A doença no homem pode ocorrer de forma assintomática ou apresentar sintomas que podem variar desde uma febre passageira a uma encefalite grave, caracterizando- se por um quadro de febre indiferenciada, cefaléia, mialgia, faringite, fraqueza muscular, diarréia e conjuntivite, sendo que em alguns casos, evoluem para acometimento do SNC (ARTSOB et al., 2009). Para cada caso de encefalite, ocorrem em média 140 casos de febres indiferenciadas. No período de 1999 a 2012 ocorreram, nos Estados Unidos, 36.801 casos da doença com 1.506 óbitos (CDC, 2013), como mostra a tabela de evolução da doença durante os anos citados. 
Tabela 1 - Evolução anual do número de casos da doença e óbitos nos EUA desde 1999.

\begin{tabular}{cccc}
\hline Ano & Casos da Doença & Óbitos \\
\hline 1999 & 62 & 7 \\
2000 & 21 & 2 \\
2001 & 66 & 10 \\
2002 & 4.156 & 284 \\
2003 & 9.862 & 264 \\
2004 & 2.539 & 100 \\
2005 & 3.000 & 119 \\
2006 & 4.269 & 177 \\
2007 & 3.630 & 124 \\
2008 & 1.356 & 44 \\
2009 & 720 & 32 \\
2010 & 1.021 & 57 \\
2011 & 712 & 43 \\
2012 & 5.387 & 243 \\
TOTAL & 36.801 & 1.506 \\
\hline & & \\
\hline
\end{tabular}

Fonte: (CDC, 2013)

Pacientes com a Febre do Oeste do Nilo, geralmente se recuperam dentro de um período de 7-10 dias. Menos de 1\% das infecções resultam na doença humana neuroinvasiva grave, que podem ser essencialmente classificadas em três síndromes clínicas: meningite, encefalite ou paralisia flácida aguda (KRAMER; LI; SHI, 2007). As características clínicas destas síndromes podem estar presentes ao mesmo tempo no mesmo paciente, sendo que a idade avançada é o principal fator de risco para o desenvolvimento de síndromes encefálicas (HAYES et al., 2005). Pacientes com encefalite têm uma maior taxa de mortalidade e complicações mais graves do que os pacientes com meningite (BODE et al., 2006). Nos últimos 15 anos, o vírus tem indicado uma tendência de aumento significativo da doença neurológica grave e fatal em humanos, aves e/ou equinos (ARTSOB et al., 2009).

Autópsias realizadas em humanos que morreram quatro semanas após a inoculação experimental do vírus, como tentativa para o tratamento de câncer, encontraram WNV através do isolamento viral nos rins, linfonodos, fígado e pulmões, achados similares ao encontrado em animais de laboratório (SOUTHAM; MOORE, 1954). 
A maioria das infecções humanas ocorrem naturalmente pela transmissão dos mosquitos, mas infecções adquiridas em laboratório já foram relatadas, por isso, em casos clínicos suspeitos, o diagnóstico de todas as espécies animais, particularmente aves, devem ser realizados em nível de biocontenção 3, seguido de procedimentos laboratoriais apropriados (RICHMOND; MCKINNEY, 1999). Outras vias de transmissão entre os seres humanos pode ser o contato direto de sangue, transplante de órgãos, via transplacentária ou aleitamento materno. A transmissão oral também foi demonstrada experimentalmente em aves, ratos e hamsters (KOMAR et al., 2003).

O período de incubação para a encefalite ocasionada pelo WNV em equinos é estimada entre 3-15 dias. Uma viremia passageira de baixo título viral precede o início da infecção (BUNNING et al., 2002), mas a encefalite ocorre somente em pequena porcentagem dos cavalos infectados e a maioria dos cavalos infectados não apresentam sinais clínicos (OSTLUND; ANDRESEN; ANDRESEN, 2000). A doença em cavalos é frequentemente caracterizada por ataxia de suave a severa, mas podem exibir fraqueza, fasciculação muscular, debilidade generalizada, falta de coordenação dos membros traseiros e déficit do nervo craniano (TROCK et al., 2001).

A febre é uma característica reconhecida inconsistente, o tratamento é de suporte e os sinais podem se resolver ou progredir para um quadro terminal. A mortalidade é aproximadamente de um em cada três cavalos que apresentam sintomas. Os diagnósticos diferenciais incluem outras encefalites por arboviroses (por exemplo encefalites oriental, ocidental ou encefalite equina venezuelana e encefalite japonesa), mielite protozoária equina (Sarcocystis neurona), herpesvirus-1 equina, doença de Borna e hidrofobia (OIE, 2007).

A maioria das infecções nos seres humanos e cavalos são assintomáticas ou com sinais febris suaves de causa não específica. Entretanto, os casos potenciais fatais de meningites ou encefalites podem evoluir com índice de mortalidade reportadas entre $26 \%$ a $43 \%$ em humanos e $9 \%$ a $16 \%$ em cavalos (CHEVALIER et al., 2004).

Em fevereiro de 2003, o departamento de agricultura dos Estados Unidos (USDA) emitiu uma licença para uma vacina, inativada pelo formol derivada da cultura celular, para o uso em cavalos e licenciou uma vacina viva de canarypoxvírus como vetor para o uso nos equinos. Estas vacinas demonstraram suficiente eficácia e segurança em equinos adequadamente vacinados, como mostra a figura 6 . A vacinação pode ser útil em prevenir os sinais neurológicos associados com a infecção do WNV (OIE, 2007). 


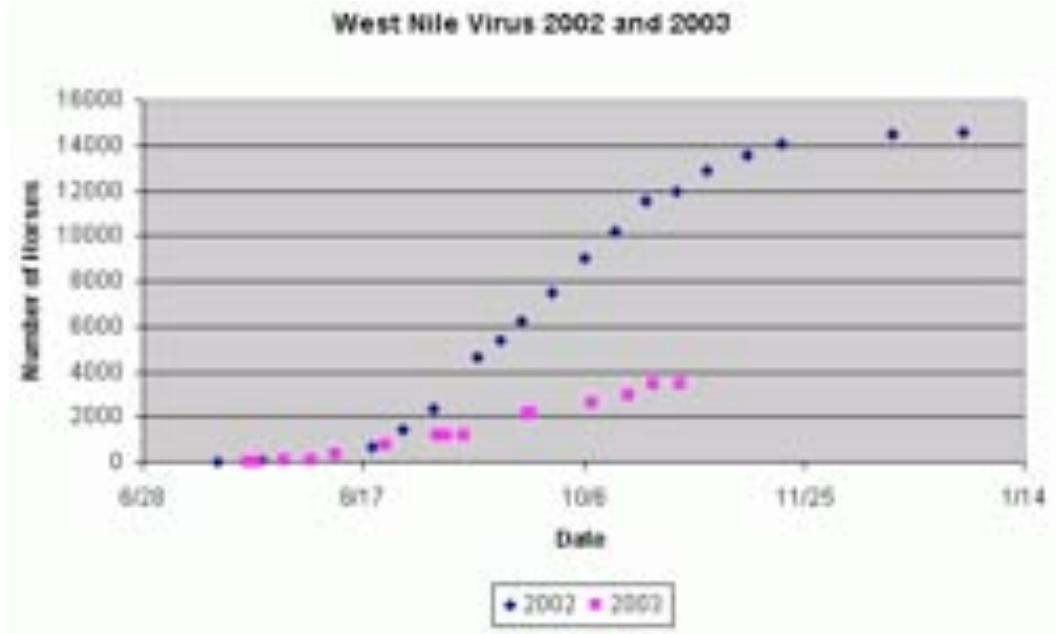

Figura 6 - Número de casos de WNV em cavalos antes da vacinação e um ano após a aplicação da mesma.

Fonte: (NG et al., 2003)

Recentemente, uma nova classe de vacinas contra Flavivirus está sob avaliação e baseiam-se na produção de partículas virais defeituosas, as quais não são capazes de se espalhar entre as células normais e ineficazes no surgimento de doenças em animais vacinados. Uma proposta de ciclo único com encapsidação defeituosa do Flavivirus da vacina, parece ser razoavelmente de baixo custo de produção, potente e segura nos imunocomprometidos (WIDMAN; FROLOV; MASON, 2008). No entanto, a adequação da implantação da vacina para uso humano ou animal permanece questionável devido ao número relativamente baixo e gravidade dos casos em todo o mundo e as grandes dificuldades no controle do vírus de se espalhar através do reservatório animal, representado por espécies susceptíveis de aves (MONINI et al., 2010).

Embora muitas espécies de aves, incluindo galinhas, sejam resistentes à doença, o resultado da infecção é geralmente fatal em aves suscetíveis, sendo que as aves podem exibir sinais neurológicos antes da morte (STEELE et al., 2000).

$\mathrm{Na}$ epidemia ocorrida em 1999 em Nova York, além de humanos, vários corvos americanos (Corvus brachyrhynchos) morreram num raio de aproximadamente $8 \mathrm{~km}$ do epicentro da epidemia humana. Estes corvos apresentavam evidências histopatológicas de encefalites caracterizadas por uma aglutinação perivascular das células mononucleares, predominantemente linfócitos e neurofagia, consistentes com encefalite viral, confirmada por reação de ELISA com títulos de 640 (ANDERSON et al., 1999).

Em adição a estas espécies silvestres, vários exemplares da coleção do zoológico de Queens e do zoológico de Bronx, também morreram, tais como os flamingos-chilenos (Phoenicopterus chilensis), os biguás (Phalacrocorax bougainvillei), as águias-carecas 
(Haliaeetus leucocephalus), as gralhas-norte-americanas (Pica pica), marrecas-asa-debronze, (Anas specularis), os faisões-imperiais, (Lophophorus impeyanus) entre outros (STEELE et al., 2000).

Vertebrados não aviários infectados incluem roedores, morcegos, canídeos, felinos e répteis, além de equinos e humanos. Muitas espécies de mamíferos parecem ser suscetíveis à infecção do vírus, com descrição de encefalite fatal em mamíferos de várias linhagens taxonômicas diferentes incluindo, vacas, gatos, cachorros, cavalos, carneiros, coelhos, guaxinins, esquilos, gambás, morcegos, lhamas, alpacas, cabras, ursos, cervos, renas, macacos e rinocerontes (USGS, 2008).

Répteis que podem ser infectados abrangem o jacaré americano, o crocodilo do Nilo, o lagarto monitor e a iguana verde (STEINMAN et al., 2003). Estudos experimentais têm indicado jacarés americanos como hospedeiros de amplificação eficiente para o vírus e um possível fator na proliferação na região da Costa do Golfo, sudeste da América do Norte. Jacarés infectados desenvolvem níveis de viremia que podem sustentar a transmissão do vírus aos mosquitos e que são de duração muito mais longa do que os observados em aves, com uma viremia com tempo maior de 2 semanas em jacarés contra o máximo de 7 dias em aves (KLENK et al., 2004).

Uma ampla variedade de mamíferos e não mamíferos, como roedores, coelhos, esquilos, répteis e anfíbios, que são suscetíveis à infecção natural ou experimental com o WNV, também foram identificados como animais capazes de desenvolver viremia suficiente para permitir a transmissão através da alimentação de mosquitos (BOWEN; NEMETH, 2007).

\subsection{EPIDEMIOLOGIA}

A principal dificuldade na epidemiologia das doenças virais é a indisponibilidade de dados, especialmente o número de casos de cada doença, por isso a pesquisa epidemiológica é a fonte tradicional de coleta de informações em surtos e epidemias de doenças virais. A finalidade destas pesquisas, em geral conduzidas por autoridades públicas, é a classificação e determinação do agente etiológico, determinação da extensão da doença e seu impacto econômico, além de tentar evitar a continuação do surto ou prevenir a recorrência da doença (TRABULSI; ALTERTHUM, 2005).

Os últimos anos têm sido marcados por diferentes episódios de doenças emergentes. Existe, constantemente, o acometimento de infecções múltiplas procedentes do rompimento de ciclos internos a nichos ecológicos e invasão do "mundo moderno" com alastramento 
vigoroso desses patógenos. A penetração de agentes etiológicos pode ser facilitada pela crescente mobilidade humana, principalmente por conta do desenvolvimento de transportes eficientes e hábitos alimentares diversos, estimando-se que determinado tipo de vírus, recentemente introduzido em uma região distante do Pacífico, poderá estar em cidades no litoral brasileiro em questão de horas. Com a invasão do ambiente natural dos vírus, provocada pela devastação de florestas e crescimento de cidades limítrofes às mesmas, as viroses emergentes passam a ser motivo de preocupação no cenário da saúde pública de nosso país (SIMONETTI, 2004).

Um desses aspectos preocupantes é a emergência de novas doenças ou re-emergência de doenças que haviam desaparecido. As infecções emergentes podem refletir o aparecimento de um vírus novo na população ou aumento da taxa de casos/infecção, de forma que uma infecção endêmica torna-se associada ao aumento na incidência de casos clínicos ou o reconhecimento de uma doença existente e não identificada (TRABULSI; ALTERTHUM, 2005).

O risco para a emergência de novos arbovírus no Brasil relaciona- se principalmente à existência de cidades grandes, populosas e infestadas por mosquitos Culex bem como o altamente antropofílico Aedes aegypti. Nas cidades poderiam ser introduzidos seres humanos ou animais infectados oriundos de sítios eco-epidemiológicos onde existem zoonoses arbovíricas (FIGUEIREDO, 2007). Apesar de animais serem a fonte mais comum de novos vírus, o fator mais frequente para o aparecimento de agentes emergentes é o comportamento humano, que aumenta a probabilidade de transferência de vírus de animais hospedeiros para o homem. Mudanças na prática da agricultura ou condições urbanas que promovam a multiplicação de roedores e vetores, favorecem o aumento da incidência de doenças em humanos, sendo que a transmissão por artrópodes é responsável pela maioria das doenças infecciosas em animais (SIMONETTI, 2004).

No caso específico do WNV como uma doença emergente, está disseminado por toda a África, Oriente Médio, parte da Europa, antiga URSS, Índia, Indonésia (PEIRIS; AMERASINGHE, 1994) e mais recentemente foi encontrado na América do Norte (LANCIOTTI et al., 1999), América Central e América do Sul (MORALES et al., 2006), como demonstra a figura 7 . 


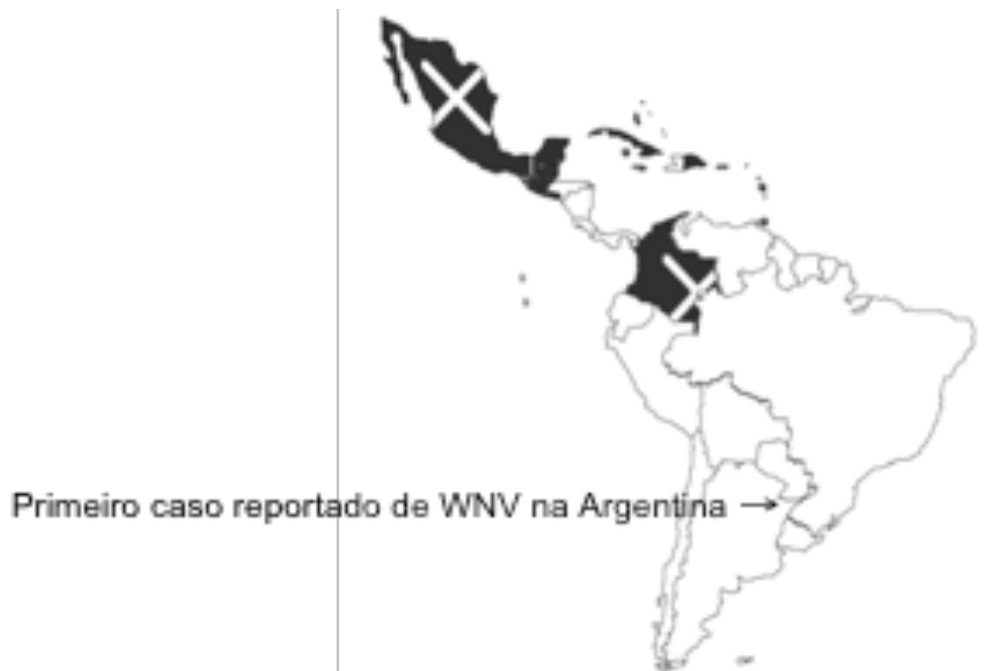

Figura 7 - Locais da América Latina e Caribe com descrição de WNV, entre 2001 e 2004. Fonte: (KOMAR; CLARK, 2006) - modificado

Durante a década de 1950, estudos clássicos de epidemiologia do vírus no Egito e no Sudão revelaram que a infecção humana era extremamente comum no delta do Nilo no qual $22 \%$ das crianças e $61 \%$ dos adultos eram imunes à doença (HURLBUT et al., 1956). Um acompanhamento realizado 15 anos mais tarde mostrou que a doença diminuiu cerca de $50 \%$ em adultos (DARWISH; IBRAHIM, 1975). Epidemias de verão foram reconhecidas no início dos anos 50 em Israel e houve recidivas em intervalos frequentes durante toda a década de 50 (GOLDBLUM et al., 1956).

Em áreas da África do Sul, com levantamento relativamente baixo de resposta imune (13\% a 20\%), uma epidemia em 1974 resultou na infecção de 55\% da população. A epidemia envolveu uma área de $2.500 \mathrm{~km}^{2}$ na zona norte e central da província do Cabo. Milhares de casos clínicos brandos foram constatados, mas sem nenhum caso de encefalite diagnosticado (MCINTOSH et al., 1976).

Quanto aos animais, anticorpos para o WNV têm sido encontrados no sangue de muitas espécies de aves migratórias na Eurásia (PEIRIS; AMERASINGHE, 1994), com isolamento do vírus em espécies migrantes, como em parulídeo (Sylvia risoria) em Cyprus e em pombas (Streptopelia turtur) na Eslováquia (ERNEK et al., 1977).

Muitas espécies de aves da Eurásia chegaram à América, sendo que estudos realizados no velho mundo (Oriente) demonstraram que em várias destas aves foram encontradas evidências de exposição ao WNV (CDC, 1999), como descritas na tabela 2: 
Tabela 2 - Lista das aves encontradas na América provenientes da Eurásia, nas quais foram encontradas evidências de contato com WNV.

\begin{tabular}{ccc}
\hline Nome popular & Nome científico & Possível forma de entrada na América \\
\hline Garça-cinza & Ardea cinérea & Deslocamento ocasional \\
Garça-vaqueira & Bulbucus íbis & Deslocamento ocasional \\
Ganso-sinaleiro & Anser anser & Ave doméstica \\
Marreco-mallard & Anas platyrhynchos & Ave doméstica \\
Falcão- eurasiano & Falco tinnunculus & Deslocamento ocasional \\
Galo-doméstico & Gallus gallus & Ave doméstica \\
Codorna & Coturnix coturnix & Ave doméstica \\
Quero-quero & Vanellus vanellus & Deslocamento ocasional \\
Maçarico-de-madeira & Tringa glareola & Deslocamento ocasional \\
Maçarico-pequeno & Calidris minuta & Deslocamento ocasional \\
Gaivota-de-cabeça-negra & Larus ridibundus & Deslocamento ocasional \\
Pomba-doméstica & Columba Lívia & Ave de estimação \\
Pomba-europeia & Streptopelia turtur & Ave de estimação \\
Pomba-de-colar & Streptopelia decaocto & Ave de estimação \\
\hline
\end{tabular}

Fonte: (CDC, 1999)

Por atingirem altos picos de viremia em um período de aproximadamente 7 dias, os passeriformes aparentam serem as aves mais competentes na transmissão do WNV, como demonstrado na figura 8.

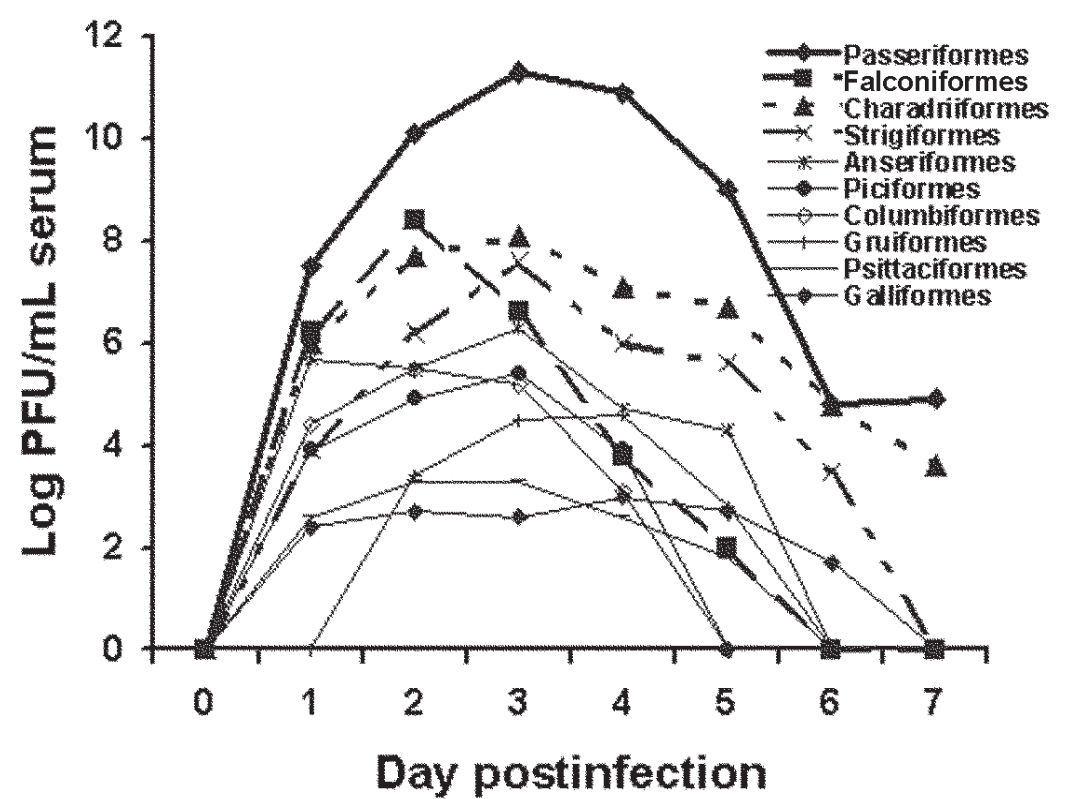

Figura 8 - Viremia do WNV comparativa em 10 ordens de aves.

Fonte: (KOMAR et al., 2003) 
Relatos já apresentados por outros países da América do Sul, como cavalos com sorologia positiva para o vírus na Colômbia em 2005 (MATTAR et al., 2005), três cavalos que morreram com a encefalite do Oeste do Nilo em 2006 na Argentina (MORALES et al., 2006), aves com sorologia positiva para o vírus em 2008, também na Argentina (ADRIÁN DIAZ et al., 2008), igualmente em aves e cavalos com sorologia positiva em 2007 na Venezuela (BOSCH et al., 2007), e recentemente casos de sorologia positiva em cavalos na região do Pantanal brasileiro (MELANDRI et al., 2012; OMETTO et al., 2013; PAUVOLIDCORRÊA et al., 2011), demonstram a trajetória do WNV nos países da América do Sul.
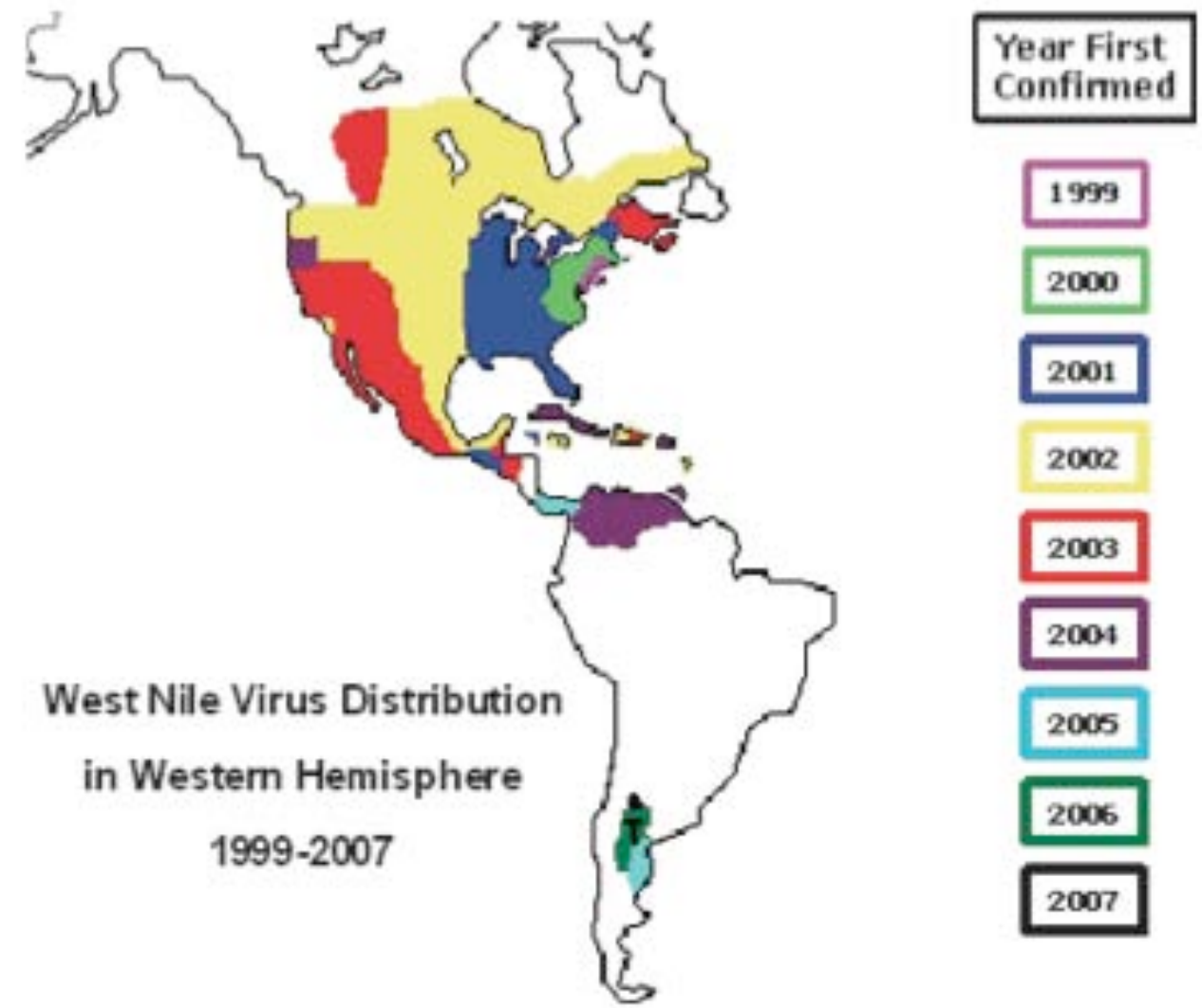

Figura 9 - Dispersão do WNV nas Américas entre 1999 e 2007. Fonte: (ARTSOB et al., 2009)

É importante notar que, enquanto a transmissão do WNV nos trópicos pode ocorrer durante todo o ano, nas regiões temperadas parece estar limitado à uma época favorável para o desenvolvimento massivo das populações de vetores (normalmente no final do Verão). Em alguns casos, é possível que os vetores potenciais de mosquito sejam infectados na primavera, depois de picarem aves migratórias e que alguns meses são necessários para o vírus se amplificar e espalhar-se numa área limitada (AUTORINO et al., 2002). No entanto, isto não pode explicar o aparecimento simultâneo de focos distintos do WNV espalhados em 
diferentes regiões na Itália, em 2008 e 2009. Desde que o mosquito infectado possa continuar a transmitir o vírus a outros animais mesmo meses após a ingestão de sangue infectado, devese considerar a possibilidade de que o vírus possa ter sobrevivido nestas regiões temperadas através da transmissão vertical. Esse fenômeno tem sido observado tanto no campo quanto em laboratório, mas sua real relevância na epidemiologia do vírus ainda está a ser avaliada (BAQAR et al., 1993; GODDARD et al., 2003).

Considerando o ciclo migratório de algumas aves, a existência de equídeos amplamente disseminados pelo território brasileiro, bem como a presença do ser humano em contato com esses animais, o potencial para o surgimento de surtos em animais e seres humanos no Brasil é preocupante. A grande variedade de possíveis hospedeiros e vetores do vírus, a capacidade de transmissão vertical em mosquitos e a transmissão horizontal em aves e mamíferos, garantem que este patógeno continuará a persistir e se proliferar dentro das Américas em um futuro próximo (ARTSOB et al., 2009).

O WNV poderia remanescer silencioso no Brasil por conta de uma proteção resultante de cruzamentos imunes com infecções por outros Flavivirus nos pássaros nativos (FIGUEIREDO, 2007). Com isso os seres humanos e equinos poderiam não desenvolver a doença neurológica grave em áreas tropicais da sua distribuição que envolve reação cruzada de anticorpos. Há inúmeros Flavivirus endêmicos e/ou enzoóticos no Caribe, América Central e do Sul, incluindo Dengue, Febre Amarela, Ilhéus, Roccio, Cacipacoré e vírus Iguape (GUBLER, 2007; SABATTINI; AVILE'S; MONATH, 1998). Assim, muitas infecções do vírus em humanos, especialmente aquelas pessoas que tiveram uma infecção anterior por Flavivirus, provavelmente apresentarão resultados positivos para a dengue por ELISA IgM e será erroneamente diagnosticado (ARTSOB et al., 2009).

Uma segunda hipótese para a não ocorrência de uma epidemia de impacto no Brasil, é descrita pela falta de um vetor que se alimente do sangue de pássaros, seres humanos e cavalos, fazendo uma ponte para o WNV (FIGUEIREDO, 2007). Os fatores intrínsecos ou extrínsecos associados a hospedeiros, vetores e do meio ambiente podem estar envolvidos na seleção de variantes genéticas do vírus que são menos virulentos (GUBLER, 2007), como na diversidade de espécies de aves em regiões tropicais que inclui muitas que não são bons hospedeiros amplificadores do WNV, portanto mosquitos que se alimentam destas espécies são menos propensos a se infectar. Isto reduz a probabilidade de uma grande amplificação viral entre os mosquitos e as populações de aves, dirigindo uma correspondente diminuição da probabilidade de ocorrência de um grande número de casos humanos (ARTSOB; LINDSAY; DREBOT, 2006). 
Interessante é o fato intrigante de que até agora houveram apenas raros casos documentados de doença neurológica grave e fatal associada à infecção pelo WNV em humanos e equinos na América do Sul e no Caribe. Pelo menos, parte desse fenômeno pode ser atribuído à vigilância limitada e à baixa capacidade de diagnóstico (ARTSOB et al., 2009).

A vigilância para o vírus em áreas tropicais e subtropicais da América Central e América do Sul é complicada pela presença de uma série de outros Flavivirus, especialmente do vírus da dengue, e pela dificuldade de diagnóstico preciso e distinção entre infecções humanas relacionadas a estes e outros vírus semelhantes (GUBLER, 2007). Além disso, nos programas de controle de vetores, há defasagem de pessoal, equipamentos e ferramentas em grande parte das regiões que necessitam deste acompanhamento. Embora existam programas de vigilância para a dengue em muitos países, a maioria dos casos suspeitos de febre do Oeste do Nilo em humanos na América Central e no Caribe não podem ser avaliados clinicamente ou confirmados, devido principalmente à falta de capacidade de diagnóstico laboratorial entre os países da região (ARTSOB et al., 2009).

Portanto, tão importante quanto as pesquisas emergenciais durante os surtos das doenças, são os estudos fora do contexto epidêmico. Desta forma, podemos definir os principais nichos ecológicos de arbovírus e tomar medidas preventivas evitando a disseminação viral pelo país e o consequente acometimento da fauna e população brasileira.

\subsection{DIAGNÓSTICO LABORATORIAL}

As grandes epidemias e surtos que ocorreram nos EUA têm contribuído consideravelmente para a melhoria do diagnóstico do WNV em humanos e animais, principalmente com foco na detecção viral ou dos anticorpos anti-WNV. Devido a estas epidemias, programas de vigilância foram reforçados, bem como o acúmulo de grandes coleções de soros humanos e animais, mas as principais dificuldades no diagnóstico da doença são a necessidade de laboratórios preferencialmente de nível de biossegurança 3 (NB3) e a necessidade de um teste multi-espécies para diagnóstico específico que possa superar a reatividade cruzada com outros Flavivirus (DAUPHIN; ZIENTARA, 2007).

O diagnóstico laboratorial de vírus inclui o isolamento e a identificação. Em geral, os isolamentos de vírus são obtidos mais facilmente das espécies aviárias. O vírus pode ser propagado em culturas de células suscetíveis, como células de rim de coelho (RK - 13), células de rim de macaco verde africano (VERO) ou ovos de galinha embrionados. Mais de uma passagem da cultura celular pode ser necessária para se observar o efeito citopático (OIE, 
2007). Na identificação desses vírus são usados os testes sorológicos clássicos, como a inibição da hemaglutinação (HI) e a soroneutralização (PRNT). Testes sorológicos rápidos como o Enzyme Linked Immuno Sorbent Assay (ELISA) utilizando anticorpos monoclonais (mAb), a hibridação in-situ e os testes moleculares, que compreendem a reação em cadeia pela polimerase (PCR), também são usados na identificação destes vírus (LANCIOTTI et al., 2000).

A resposta imune inicia-se logo após a infecção pelo WNV. No estágio inicial da infecção, o vírus replica-se e a viremia desenvolve-se. Neste estágio é possível detectar os RNAs por RT-PCR. Depois dos primeiros sintomas, o organismo passa a produzir anticorpos IgM. Neste estágio técnicas sorológicas como IgM- ELISA, HI ou PRNT podem ser aplicados. Nos estágios finais da infecção os níveis de anticorpos IgG no sangue começam a subir e persiste nos animais infectados, por isso, pode-se fazer uso das mesmas técnicas sorológicas utilizadas na detecção do IgG (MAEDA; MAEDA, 2013).

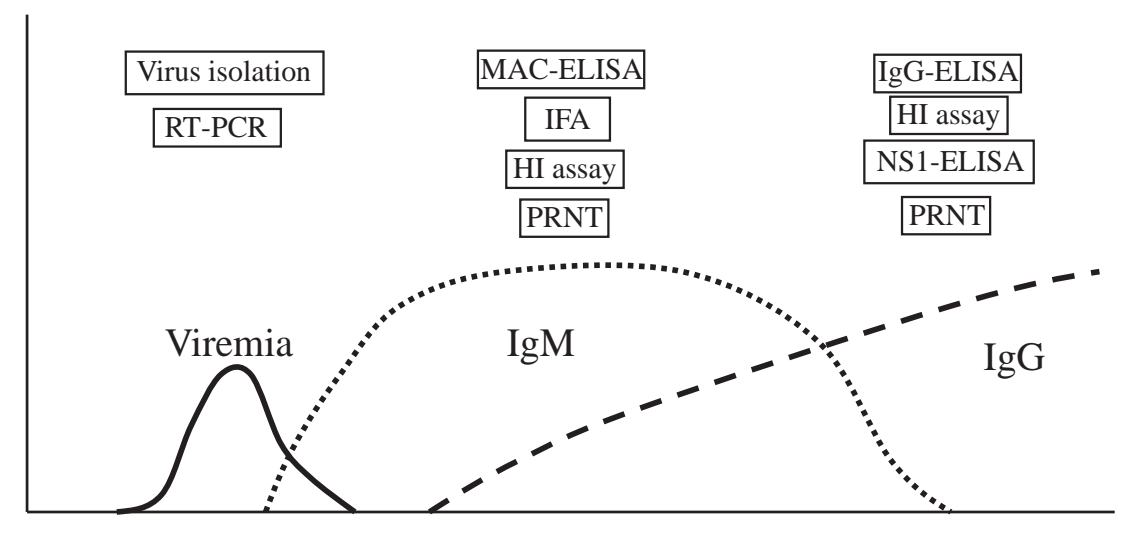

Time after infection

Figura 10 - Esquema de tempo em relação à produção de anticorpos depois da infecção por Flavivirus e os protocolos diagnósticos para as flaviviroses. Fonte: (MAEDA; MAEDA, 2013)

Testes de pesquisa de anticorpos em soros de pacientes ou de animais é de grande utilidade para o diagnóstico de infecção por WNV, tanto no âmbito de estudos de campo de grandes dimensões ou de rastreio ou quando as amostras são testadas após a fase tardia sintomática. Testes sorológicos baseiam-se principalmente na detecção de anticorpos antiproteína E, embora a reatividade cruzada da resposta de anticorpos neutralizantes contra o Flavivirus limite a especificidade dos testes. Isto é particularmente verdade em áreas onde outros Flavivirus são distribuídos simultaneamente (INNIS et al., 1989; KUNO; GUBLER; OLIVER, 1993). O teste de neutralização por redução em placa (PRNT) que detecta anticorpos neutralizantes específicos no soro, permanece como o ensaio exigido para 
confirmação de infecções por Flavivirus e identificação do agente infeccioso (LANCIOTTI et al., 2000). No entanto, estes testes são laboriosos, demorados e, por vezes, têm de ser conduzidos em laboratórios de biossegurança nível 3 (DAUPHIN; ZIENTARA, 2007).

Ainda se faz necessário o estudo adicional de ensaios sensíveis e específicos para o rápido diagnóstico diferencial de infecções pelo WNV tanto em seres humanos como em animais em campo. Tais estudos são necessários e podem ainda tirar partido do conhecimento moderno de determinantes antigênicos do vírus (JIBIN et al., 2008). Como para outros vírus, grandes expectativas são colocadas nas abordagens de teste por genoma convencional alinhadas em real-time RT-PCR, que são extremamente mais rápidos do que os métodos de cultura e podem ser ajustados para utilização em aplicações clínicas e epidemiológicos (MOUREAU et al., 2007). O material genético detectado pelo método molecular pode ser sequenciado, evitando a ambiguidade na identificação viral (LANCIOTTI, 2003).

Normalmente usam-se os métodos de PCR convencionais, mas há grande risco de contaminação (DOMINGO et al., 2011), por isso, um único tubo de RT-PCR em tempo real mostra muitas vantagens comparadas ao RT-PCR tradicional, pois é mais rápido, muitas vezes mais sensível, mais específico e minimiza a contaminação (LANCIOTTI et al., 2000).

Além disso, em conjunto com a extração de RNA automatizada, a reação de RT-PCR em tempo real pode ser utilizada em vigilância de grande escala e permite a quantificação de ácidos nucleicos virais (OSTLUND et al., 2001). Em vários estudos, ensaios de detecção molecular com base em primers degenerados, amplamente reativos, podem ser utilizados para a detecção e quantificação simultânea de diferentes Flavivirus utilizando diferentes primers espécie-específicos numa mesma reação (LANCIOTTI et al., 2000).

Alguns problemas são relacionados às cargas virais muito baixas que podem ser observadas especialmente em post-mortem ou em tecidos de triagem na ausência de sintomas. Semelhante aos ensaios baseados na detecção de antígeno-anticorpo, os esforços são também necessários para abordagens moleculares para ultrapassar os problemas apresentados pela semelhança ocasionalmente perto de sequências nucleotídicas entre os diferentes membros da família Flaviviridae, isto quando um diagnóstico gênero específico é requerido (NAZE et al., 2009). Embora adequado para um diagnóstico rápido e sensível para se trabalhar, os métodos moleculares são dificilmente utilizáveis em investigações de campo locais, particularmente em animais ao ar livre ou fazendas, onde o desenvolvimento de teste de campo antígeno-base seria desejável (MONINI et al., 2010).

A infecção causada pelo WNV re-emergiu como uma importante zoonose que demonstrou a capacidade de se espalhar por um continente em apenas alguns anos, causando 
doenças e mortes em humanos e cavalos. Seu futuro é imprevisível, mas espera- se que os avanços nos diagnósticos laboratoriais revelem importantes características epidemiológicas. Outros avanços científicos têm também contribuído para um melhor entendimento do vírus e da doença por ele causada, mas muitos aspectos da imunidade, patogênese e bases moleculares da virulência permanecem desconhecidos. Metodologias laboratoriais para o diagnóstico etiológico rápido deverão estar à disposição da comunidade para evitar uma rápida disseminação desta virose emergente. 


\section{OBJETIVOS}

Verificar a ocorrência do vírus da Febre do Oeste do Nilo em aves silvestres migratórias e residentes e em equídeos no Brasil, pela detecção molecular por one-step realtime RT-PCR e caracterização das estirpes circulantes, utilizando as técnicas de sequenciamento de nucleotídeo.

Analisar a circulação do vírus da Febre do Oeste do Nilo em aves silvestres migratórias e residentes e em equídeos no Brasil, por estudo soro epidemiológico pelo método de ELISA para detecção de anticorpos IgG específicos e confirmação das amostras por PRNT. 


\section{MATERIAL E MÉTODOS}

\subsection{LOGÍSTICA}

A vigilância ativa em aves selvagens apresenta obstáculos práticos, logísticos e financeiros que a tornam um desafio. Dadas as baixas quantidades de estudos virais de prevalência epidemiológica e os limitados recursos disponíveis para os esforços que são caros, é importante traçar estratégias claras e definidas, tanto nas atividades de campo como nas laboratoriais, para se obter amostra que, indiretamente, fornecerá dados importantes para o acompanhamento da entrada e disseminação do WNV no Brasil.

As regiões designadas para as coletas deste estudo foram o Parque Nacional da Lagoa do Peixe - RS, região metropolitana e litorânea próxima a Porto Alegre - RS, Ilha de Canelas - PA, Reentrâncias Maranhenses - MA, Glória - BA, Ilha de Fernando de Noronha - PE, Coroa do avião - PE, Centro de Triagem de Animais Silvestres (CETAS) - SC, Monte Negro - RO, Pontal do Paranapanema - SP e Pantanal - MT.

\subsection{DESENHO AMOSTRAL}

\subsubsection{Aves}

Como estratégia para captura de aves, foram priorizadas espécies que reconhecidamente realizam rotas de deslocamento, que acabam por interligar a região Sul ao Norte das Américas, como mostra a figura 11, além das espécies que promovem migrações intercontinentais, principalmente no que tange a Ásia e África, locais estes que abrigam a maioria das estirpes do WNV atualmente conhecidas. 


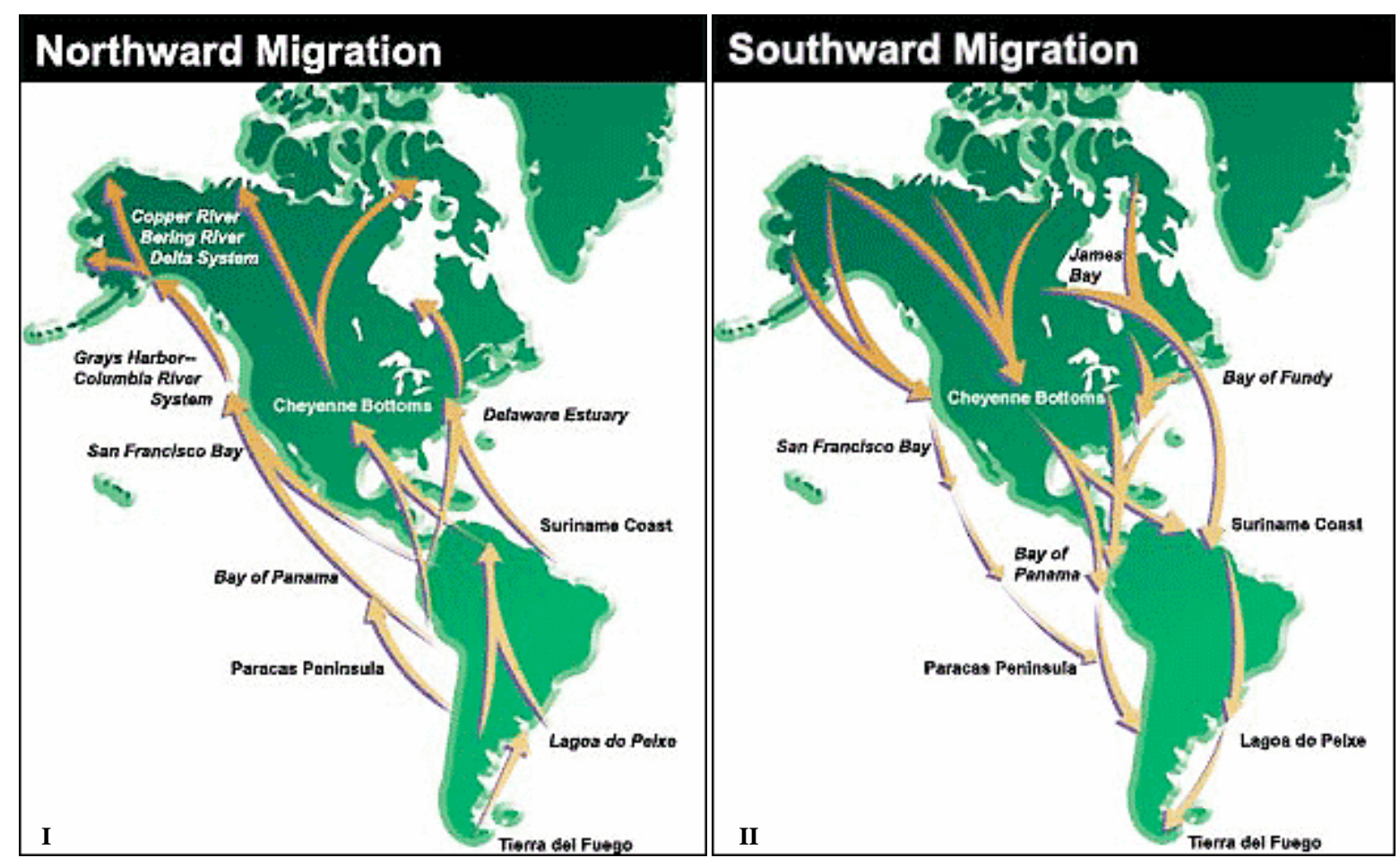

Figura 11 - (I) Ilustração das rotas migratórias de aves do Sul para o Norte das Américas e (II) do Norte para o Sul.

Fonte: (DELAWARE, 2007)

Além destas rotas, levamos em conta rotas alternativas conhecidas de aves migratórias que se deslocam em rotas intercontinentais (SICK, 1997), como mostra a figura 12.

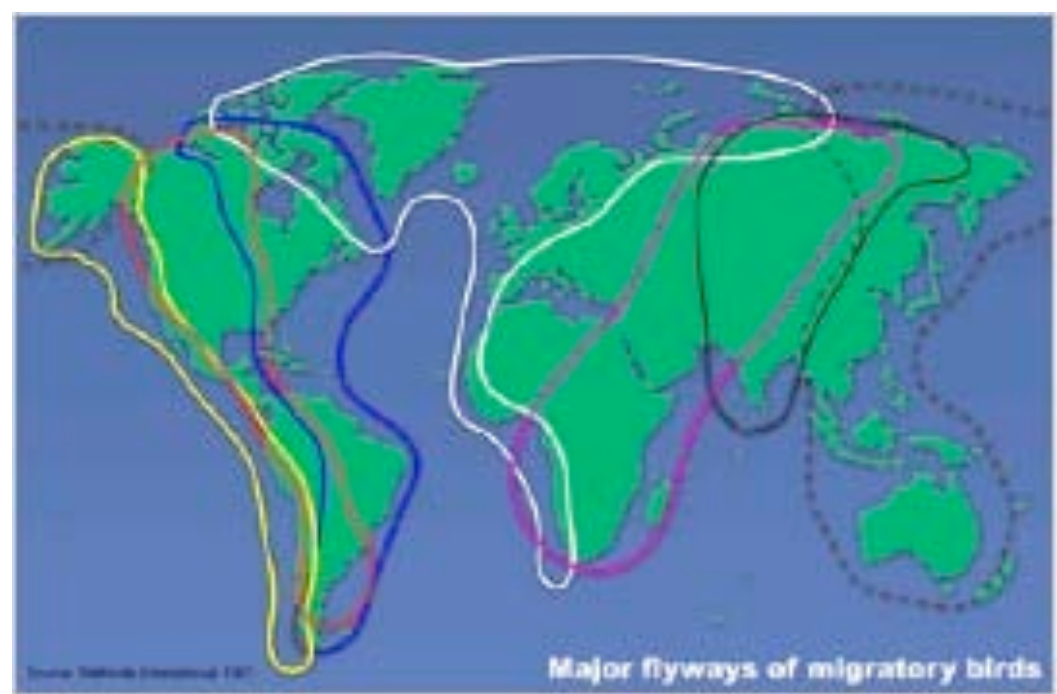

Figura 12 - Rotas continentais e intercontinentais de aves migratórias. Fonte: (USINFO, 2007)

A figura 13 descreve as rotas mais estudadas, realizadas por várias espécies de aves provenientes da região de ocorrência do WNV em seu primeiro achado na América em 1999 e as rotas para a América do Sul. 


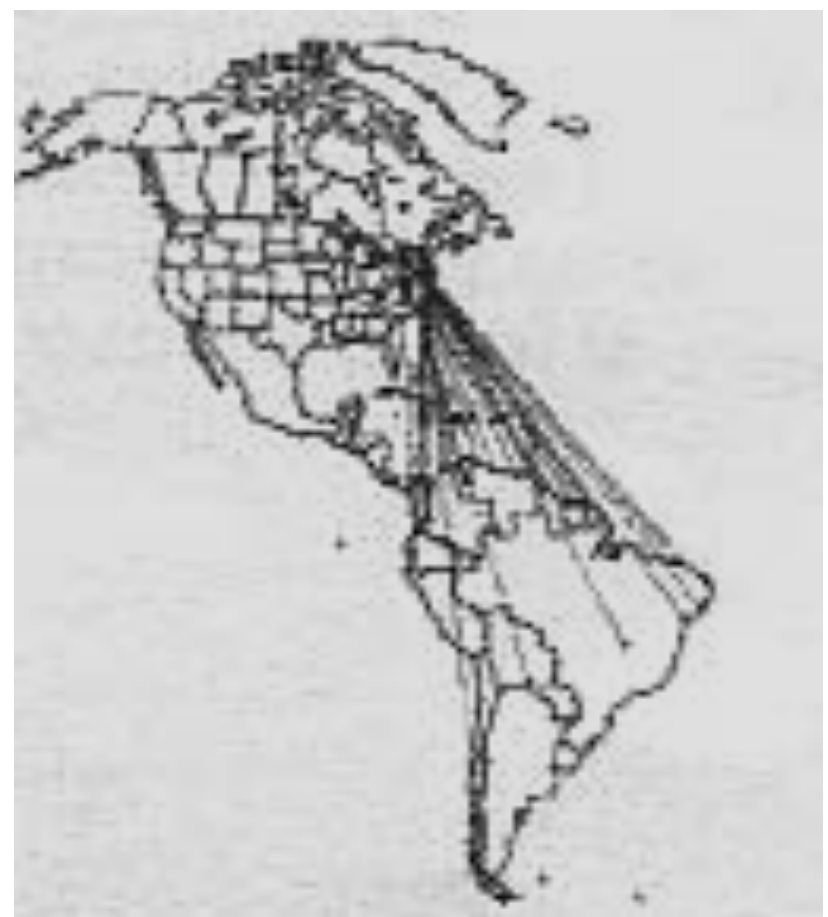

Figura 13 - Principais rotas migratórias de aves a partir do primeiro foco de WNV reconhecido na América.

Fonte: (CDC, 1999)

Foram capturadas tanto aves migrantes, como aves que faziam parte de populações que estivessem em contato com estas. Para a captura de passeriformes e algumas outras aves de pequeno porte, utilizamos redes de neblina (mist-nets) e para anatídeos e aves de maior porte utilizamos puçás.

Aves domésticas e de estimação que porventura foram encontradas nas áreas de ocorrência das aves migratórias fazem parte da amostragem. Qualquer ave que eventualmente foi encontrada morta ou veio a óbito durante as medidas de contenção e manejo, também foram aproveitadas neste estudo, bem como aves trazidas pela população local para a coleta de amostras.

Foram coletadas 3.538 amostras clínicas de aves silvestres migratórias, residentes e domésticas, no período entre 2008 a 2012. As capturas foram realizadas pela equipe de campo do Laboratório de Virologia Clínica e Molecular do ICB II- USP, bem como por grupos de pesquisadores parceiros, referências em ornitologia em cada região do estudo, como será apresentado pontualmente a seguir. Vale citar também que todas as capturas têm autorização prévia do ICMBio (Instituto Chico Mendes de Conservação da Biodiversidade). 


\subsubsection{Ilha de Canelas - Pará}

A partir de novembro de 2008 iniciou-se o monitoramento na Ilha de Canelas, município de Bragança - PA, em parceria com a equipe do Prof. Severino Mendes de Azevedo Jr., da Universidade Federal Rural de Pernambuco (UFRPE) e Agência de Defesa Agropecuária do estado do Pará - Ministério da Agricultura (ADEPARA-MAPA). As expedições foram realizadas anualmente, sempre no primeiro e segundo semestre de cada ano com o intuito de monitorar a possível circulação viral no momento da chegada e partida das aves migratórias na região.
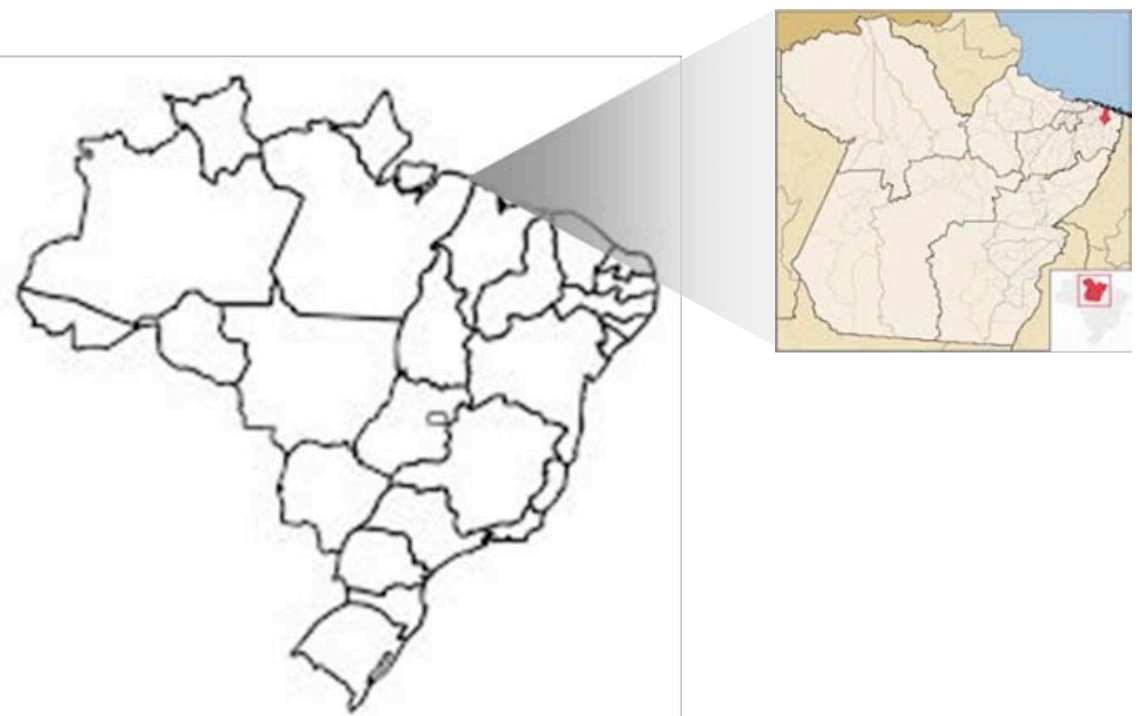

Figura 14 - Mapa de localização das amostras coletadas na Ilha de Canelas.

Na primeira expedição realizada no período de chegada das aves, entre Outubro e Novembro de 2008, capturamos 87 aves e no semestre seguinte, período de partida das aves, entre abril e maio de 2009, foram capturadas 135 aves.
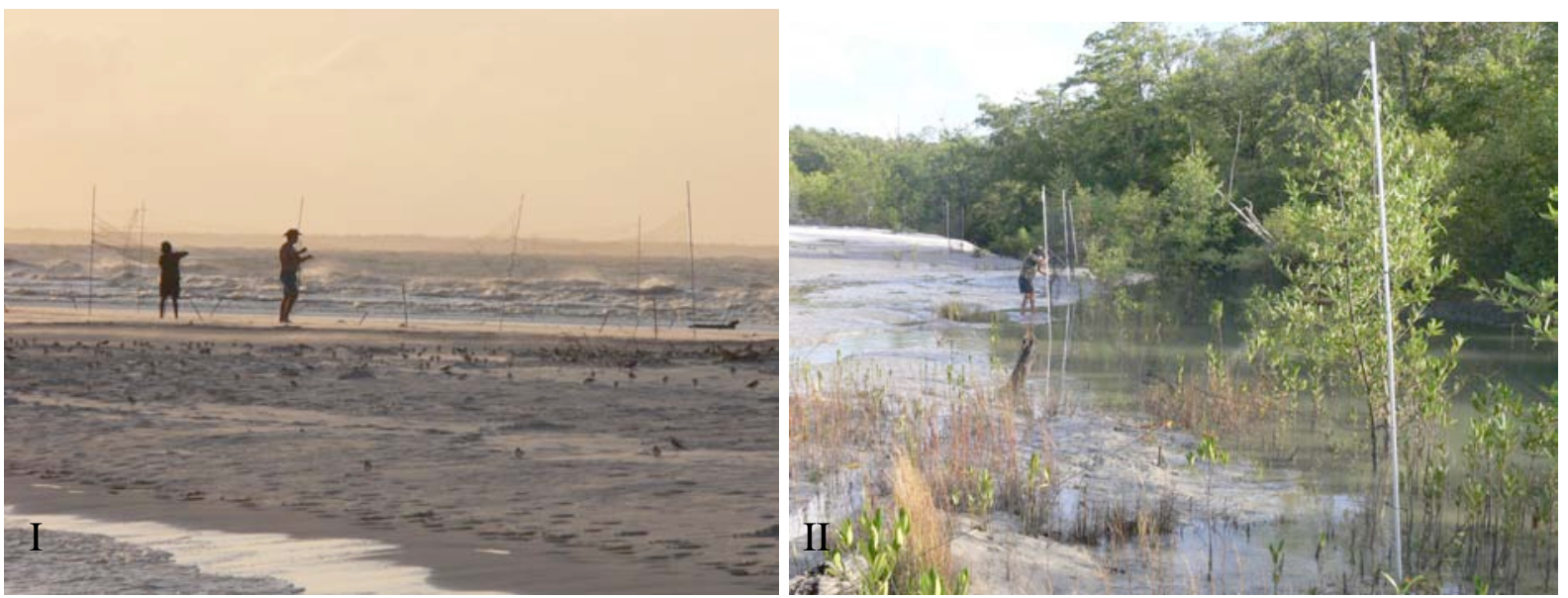

Figura 15 - Disposição das redes de neblina em duas localizações diferentes na Ilha de Canelas: (I) praia e (II) borda da mata.

Fonte: (EQUIPE DE CAMPO, 2013) 
Nesta expedição pioneira a este ponto de coleta, contamos com a participação internacional do ornitólogo Dr. Nicolas Gaidet do CIRAD - França.

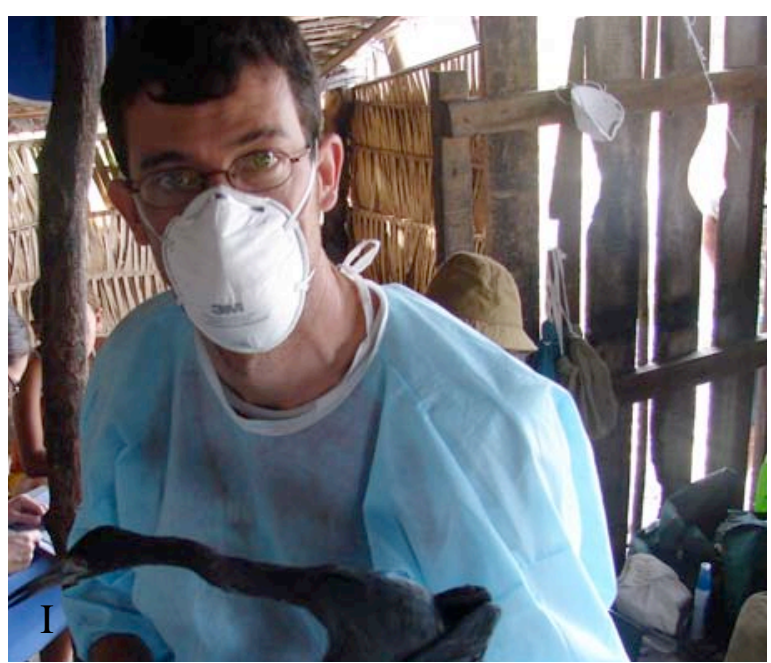

Figura 16 - (I) Dr. Nicolas Gaidet em campo e (II) base de apoio.

Fonte: (EQUIPE DE CAMPO, 2013)

Ainda no ano de 2009 foram realizadas duas novas expedições, em outubro e dezembro, com captura de 152 e 279 aves, respectivamente. No último ano do monitoramento da região em 2010, as expedições aconteceram em abril e novembro, com a coleta de 234 na primeira e 205 aves na segunda etapa, fechando assim o ciclo de monitoramento epidemiológico do local com um total de 1092 amostras coletadas na região, composto principalmente por aves migratórias, como exemplificado nas imagens abaixo.
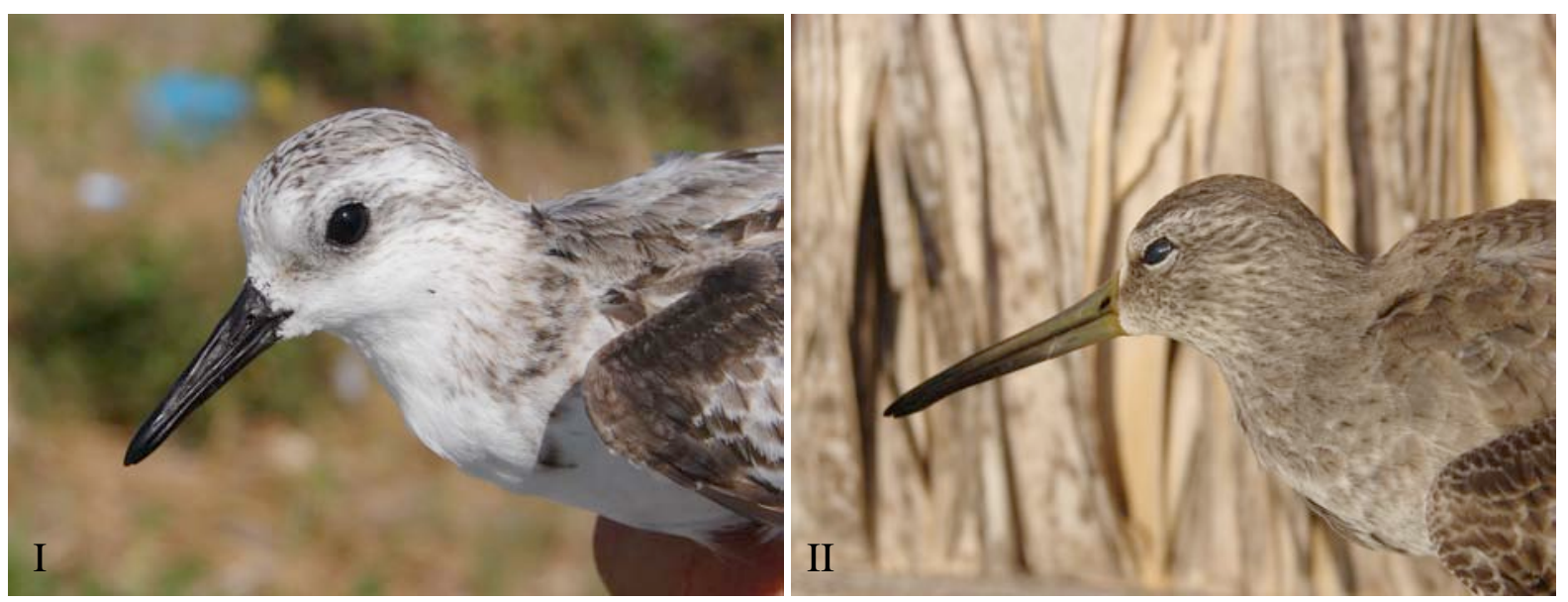

Figura 17 - Principais espécies capturadas na região: (I) Calidris pusilla e (II) Limnodromus griseus

Fonte: (EQUIPE DE CAMPO, 2013) 


\subsubsection{Ilha da Coroa do Avião - PE}

Ainda em colaboração com a equipe do Prof. Severino, coletamos amostras na Ilha da Coroa do Avião - PE. A ilha constitui parte do complexo de áreas úmidas do Canal de Santa Cruz (um braço de mar que circunda a ilha de Itamaracá), litoral norte de Pernambuco, cerca de $50 \mathrm{~km}$ da cidade do Recife. Formada pelo aporte de sedimentos originários do rio Timbó e do Canal de Santa Cruz, é constituída por um banco de areia, formando uma pequena ilha com gramíneas em expansão. Face à redução da área disponível para forrageamento, bandos de maçaricos e batuíras repousam no aguardo da baixa-mar, quando vão em busca de maior oferta de alimento. A riqueza de invertebrados marinhos, itens alimentares de algumas espécies de aves, contribui para a permanência de populações durante todo $\mathrm{o}$ ano (AZEVEDO-JÚNIOR; LARRAZÁBAL, 2011).

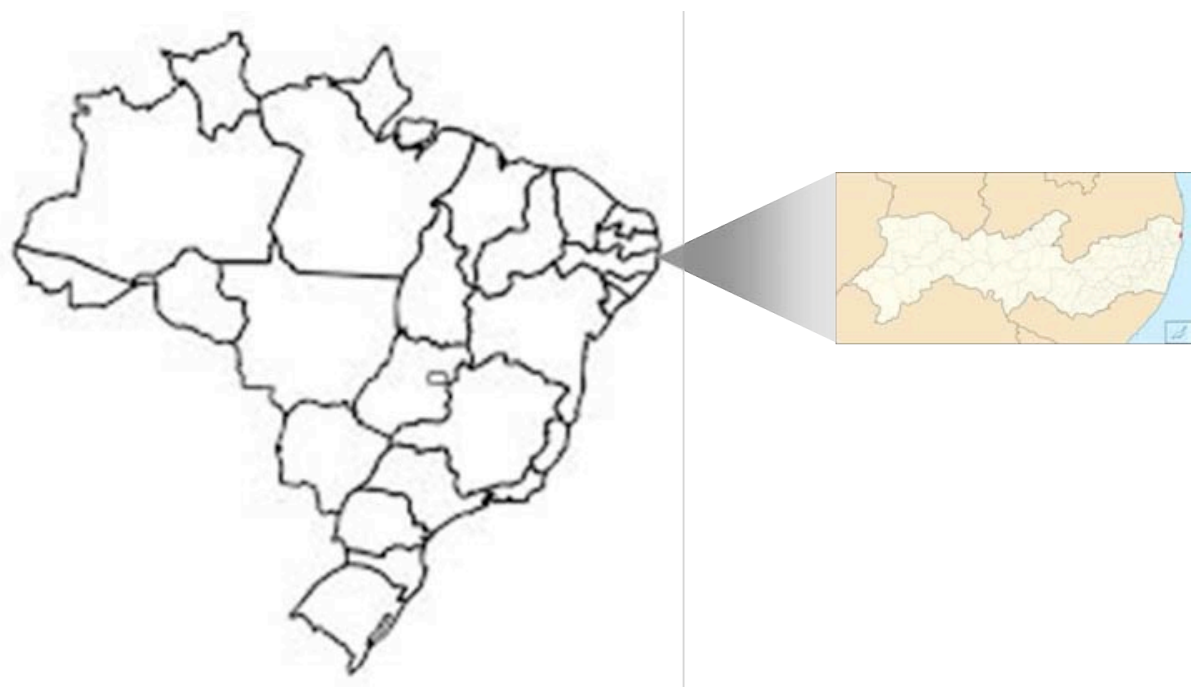

Figura 18 - Mapa de localização das amostras coletadas na Ilha da Coroa do Avião.

Infelizmente nesta expedição não foi possível a captura de nenhuma ave nas redes de neblina, então foram coletadas 18 fezes frescas da praia, provenientes de bandos de aves conhecidos. 


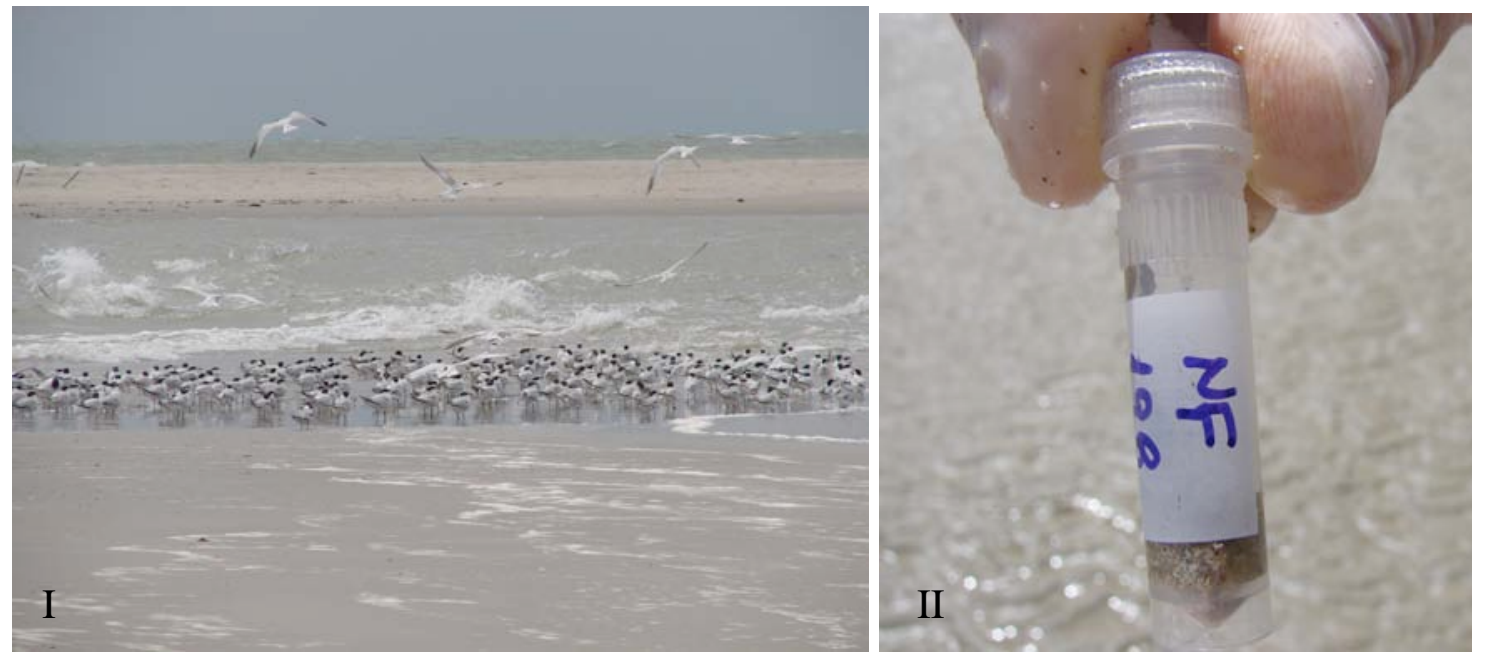

Figura 19 - (I) Bando de aves em revoada e (II) criotubo com fezes coletadas na areia. Fonte: (EQUIPE DE CAMPO, 2013)

\subsubsection{Glória - Bahia}

Com a mesma equipe também foi possível realizar apenas uma expedição científica para coleta de amostras na cidade de Glória - BA, em setembro de 2008.

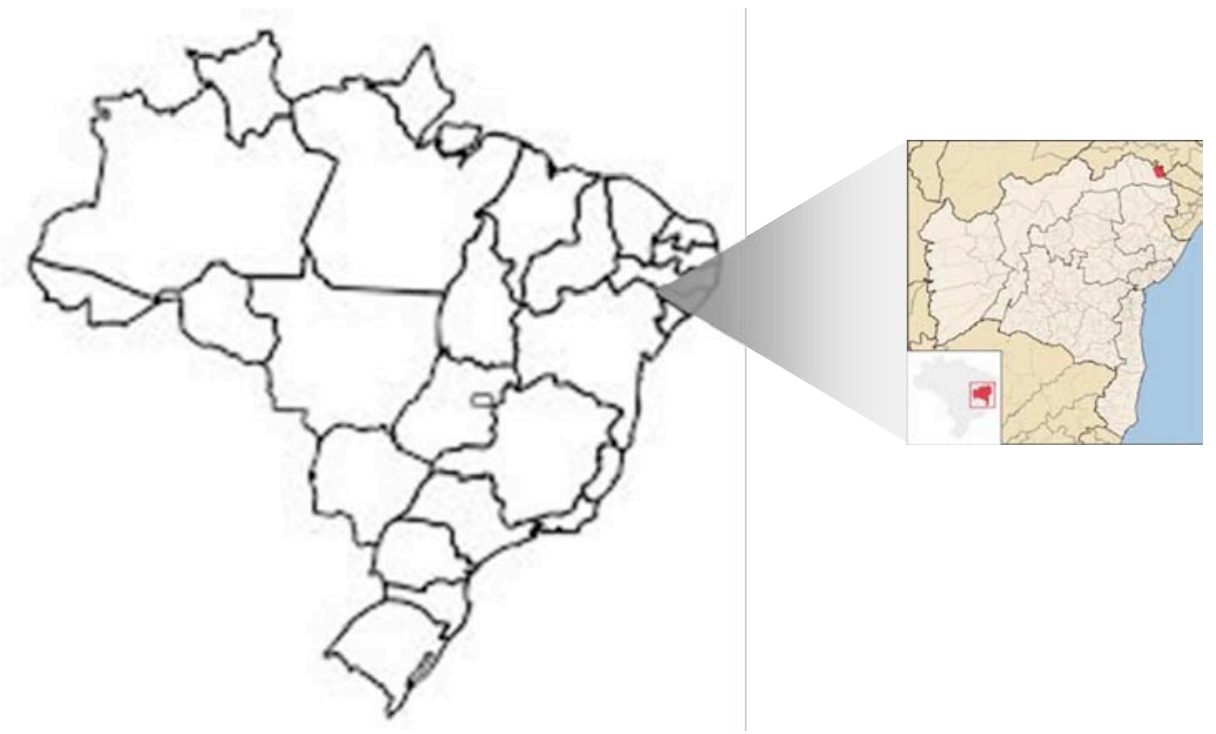

Figura 20 - Mapa de localização das amostras coletadas em Glória.

Este local foi a única amostragem do estudo que comtemplou o bioma Caatinga e que teve como principal foco de coleta, amostras de aves silvestres residentes. Foi possível a captura de um total de 71 aves, como exemplificado a seguir. 


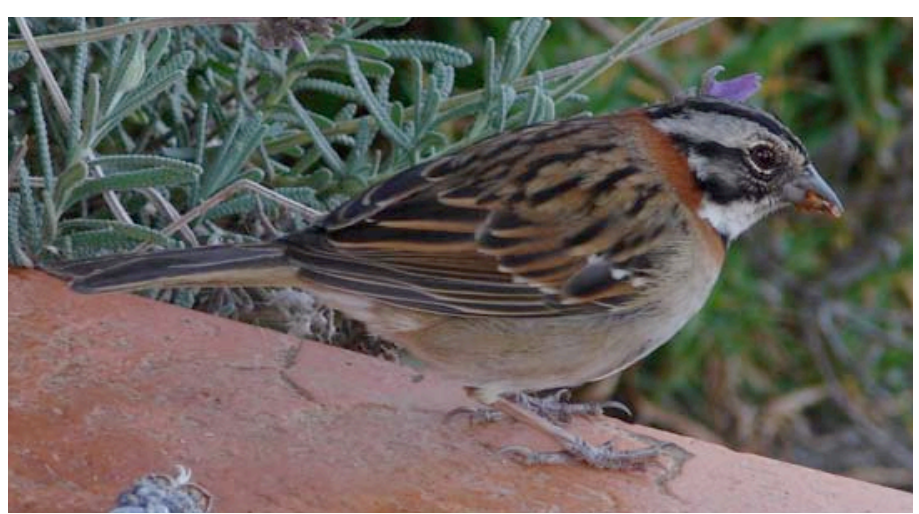

Figura 21 - Principal espécies capturada na região: Zonotrichia capensis. Fonte: (EQUIPE DE CAMPO, 2013)

\subsubsection{Parque Nacional da Lagoa do Peixe - RS}

Em parceria com o Centro Nacional de Pesquisa e Conservação das Aves Silvestres (CEMAVE - ICMBio), realizamos em novembro de 2009 a primeira expedição para captura de aves migratórias no Parque Nacional da Lagoa do Peixe (PNLP) - RS, no momento da chegada das aves migratórias em território brasileiro.

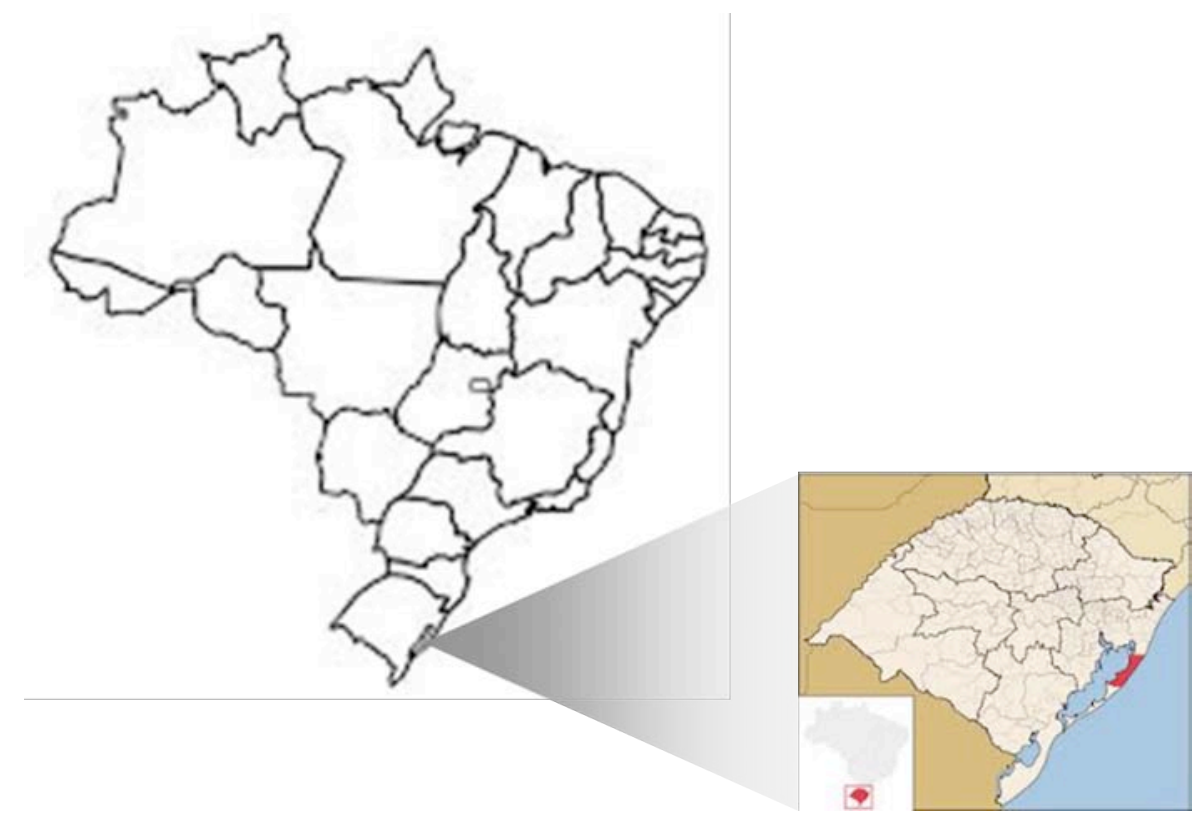

Figura 22 - Mapa de localização das amostras coletadas no PNLP.

O local foi eleito por sua peculiaridade, sabidamente conhecido como ponto de estadia de várias aves migratórias que ficam em contato com aves residentes, provindas da América do Norte e Central de locais onde já foi isolado o WNV. As aves procuram a região não apenas pelo clima favorável como também pela grande oferta de alimentos, possibilitando a muda de penas e acúmulo de gordura para migrar para a América do Norte no final do verão 
Brasileiro (ARAÚJO et al., 2004). O PNLP é hoje reconhecidamente a maior fonte de migração de aves do Brasil, tanto pela diversidade quanto pela quantidade de animais encontrados na área (Figura 23). A migração ocorre no período de setembro a maio, determinando assim a escolha do período para realização das capturas. As aves migratórias encontradas na área são, em sua maioria, provenientes de países como EUA e Canadá, locais onde o WNV encontra-se presente. O Parque é uma das mais importantes áreas de pouso e invernada de aves migratórias do país e está localizado entre os municípios de Mostardas, Tavares e São José do Norte e está compreendido entre o Oceano Atlântico e a Lagoa dos Patos - RS (ARAÚJO et al., 2004).

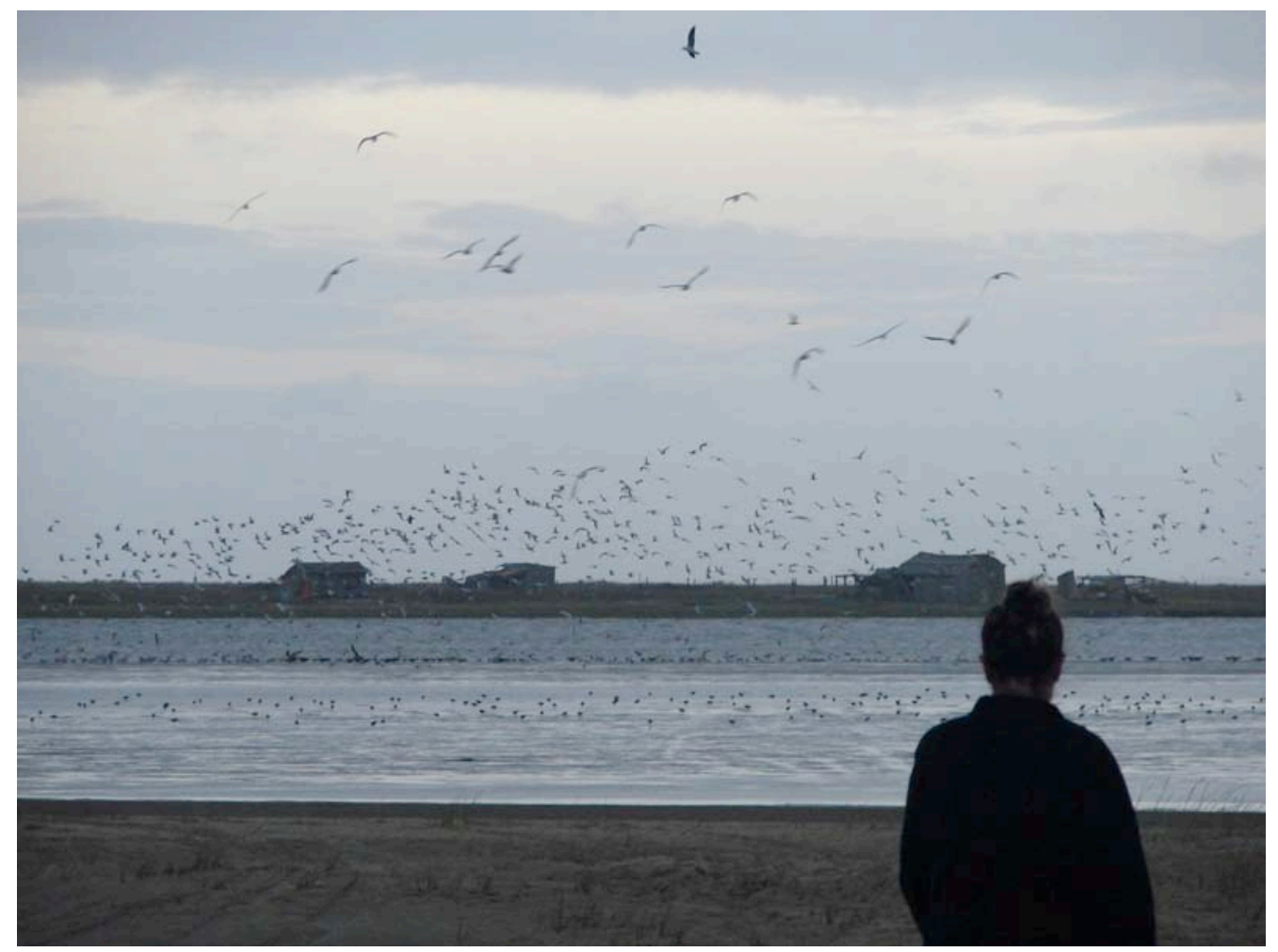

Figura 23 - (I) Bandos de aves em revoada no PNLP.

Fonte: (EQUIPE DE CAMPO, 2013)

Em março de 2010, foi realizada nova expedição ao PNLP para coleta de amostras no momento do retorno das aves migratórias para a América do Norte. Para tentar aumentar nosso número amostral de aves capturadas, contamos com o auxílio de dois funcionários do Parque que elaboraram um novo modelo artesanal de armadilha para captura das aves, que era composto por rede de pesca e lanterna de grande intensidade ligada a uma bateria. $\mathrm{O}$ princípio de funcionamento era a busca de animais abrigados nos campos durante o período noturno. Mirávamos a luz nestes pequenos bandos e outra pessoa no mesmo momento arremessava a rede de pesca para a contenção dos mesmos. O equipamento está demostrado na figura 24. 

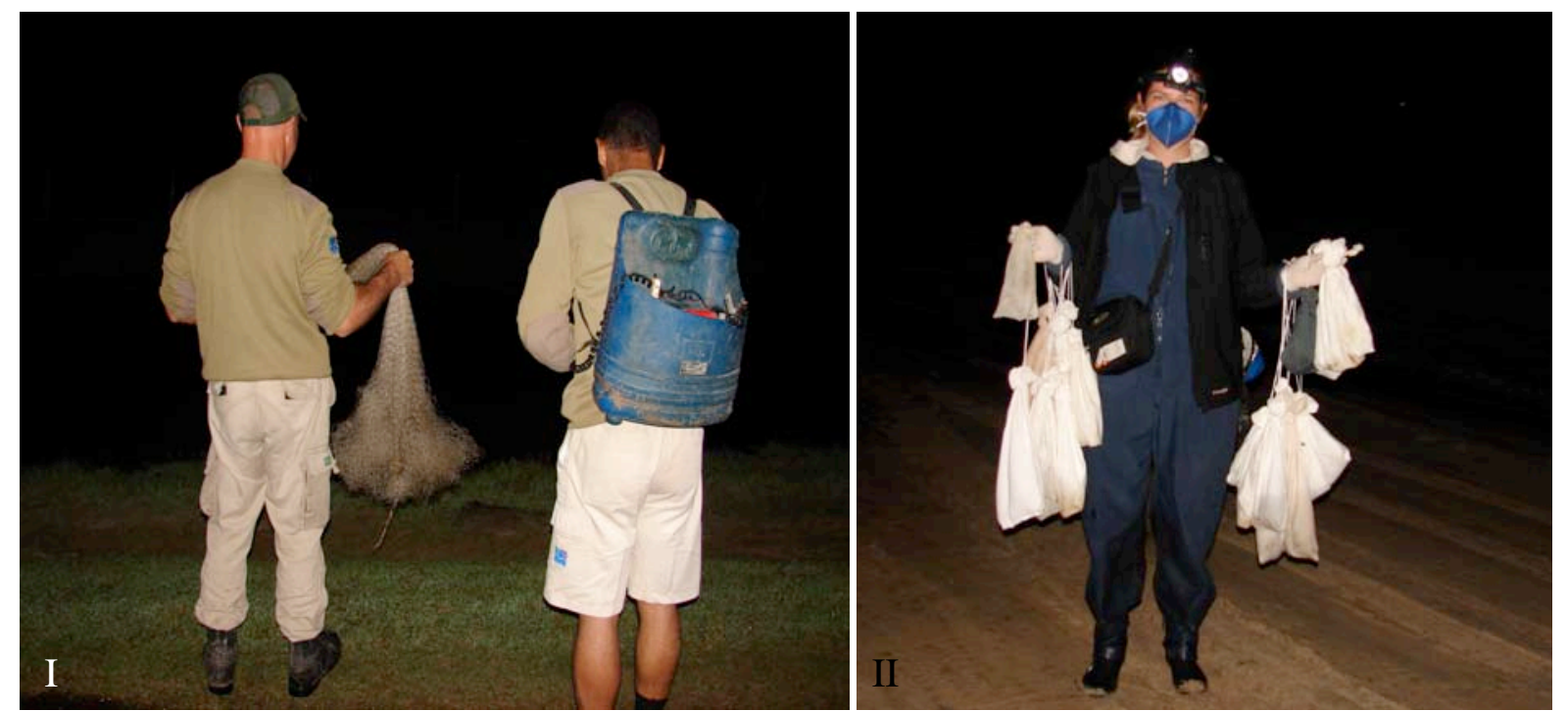

Figura 24 - (I) Os dois funcionários do parque carregando os equipamentos da armadilha artesanal e (II) o resultado da coleta por este método de captura.

Fonte: (EQUIPE DE CAMPO, 2013)

$\mathrm{Na}$ expedição de novembro de 2009 foi possível capturar 212 aves migratórias e residentes em contato com as mesmas e na segunda expedição em março de 2010, foi possível capturar 184.

Em novembro de 2011, foi realizada novamente expedição ao Parque, dando continuidade ao ciclo de coletas na época da chegada das aves migrantes provenientes da América do Norte. Apesar da época ideal, número similar de integrantes, dias de expedição e de redes dispostas, o clima estava instável, deixando a lagoa extremamente seca, com a observação e captura de poucos animais. Por este motivo, optamos por recolher as fezes frescas à beira mar, provenientes de bandos homogêneos previamente identificados pelos ornitólogos da equipe (GAIDET et al., 2007).

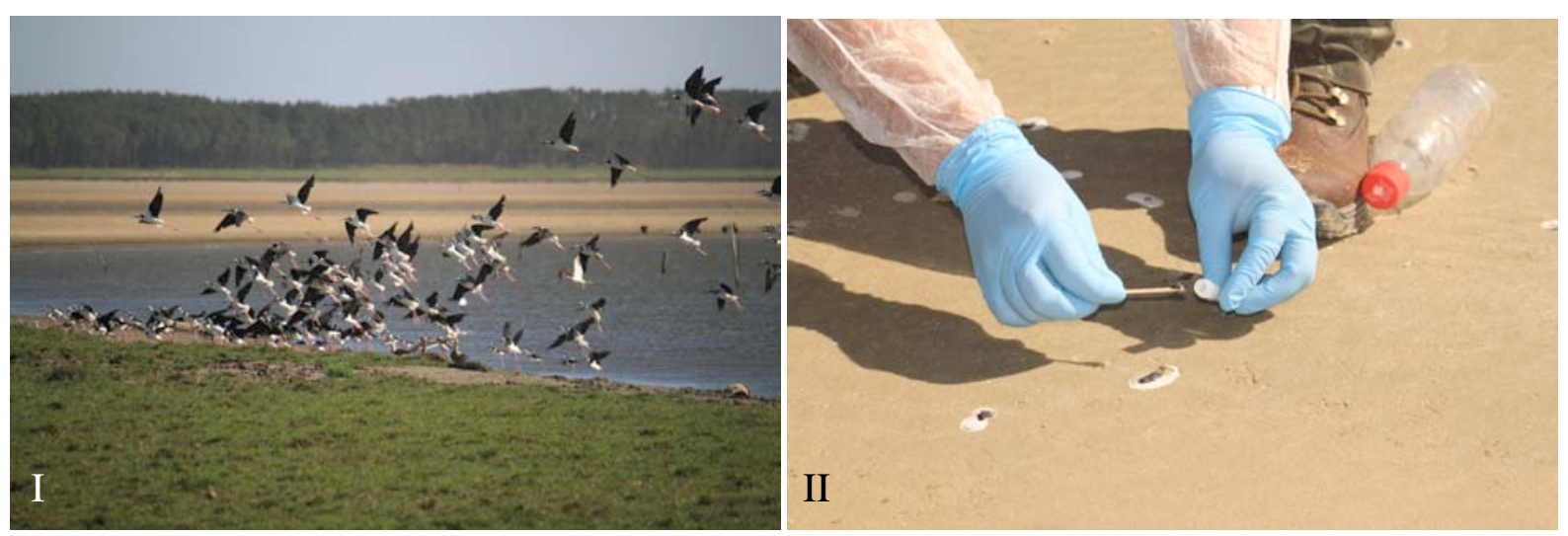

Fig 25 - (I) Bando homogêneo de aves em revoada e (II) coleta de material de fezes frescas. Fonte: (EQUIPE DE CAMPO, 2013) 
Apesar dos esforços de toda a equipe para manejo das redes para locais com visualização mais intensa dos bandos, conseguimos coletar amostras de apenas 6 animais que caíram nas redes durante os 10 dias de expedição. Quando ainda havia esperança de novas coletas, fomos surpreendidos por uma grande tempestade de areia e ventos fortes seguidos de chuvas torrenciais que desmontaram barracas, redes e causou grande prejuízo físico, mental e profissional a todos os membros da equipe, além de alguns equipamentos que ficaram em péssimo estado de uso. Eis que recebemos a informação de que um ciclone extratropical estava a caminho e nos surpreenderia abruptamente e em breve, houve um enorme aumento no fluxo da água chegando a ocasionar a junção da lagoa ao mar e impossibilitando, não só o trabalho com os animais, como também a permanência do acampamento na região. Foi então que o responsável pelo expedição e funcionário do ICMBio, decidiu por fim, levantarmos acampamento e voltarmos à civilização. Nesta expedição totalizamos 87 amostras coletadas, dentre elas os 6 animais capturados e o restante de fezes frescas coletadas na praia.

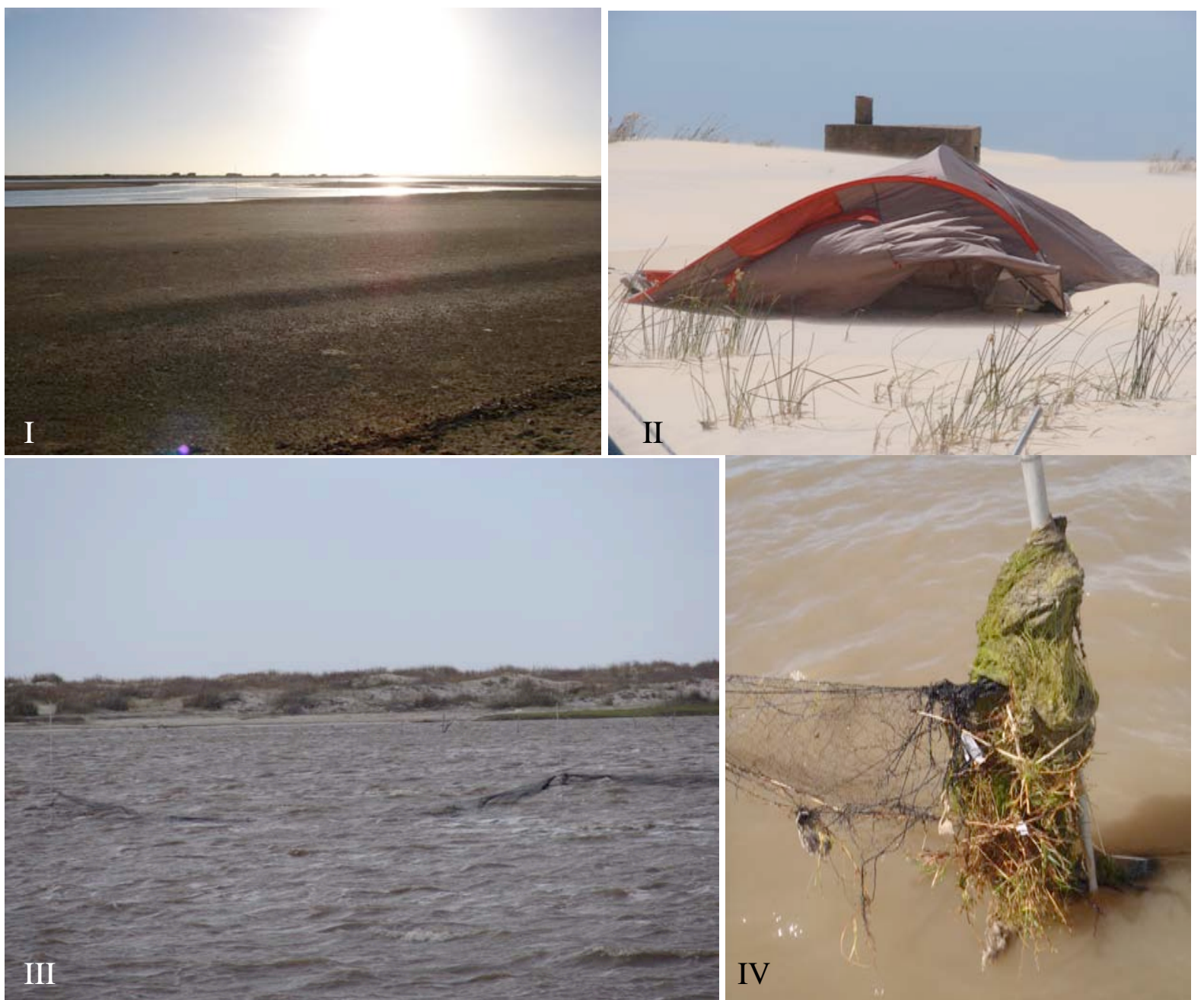

Figura 26 - (I) seca nos primeiros dias de expedição, (II) perda de material de acampamento em decorrência dos fortes ventos, (III) a consequente cheia com inundação da lagoa e submersão das redes de neblina e (IV) perda do material de captura.

Fonte: (EQUIPE DE CAMPO, 2013) 
As amostras coletadas na região do Parque Nacional da Lagoa do Peixe durante todo o período do estudo somam um total de 483 aves.
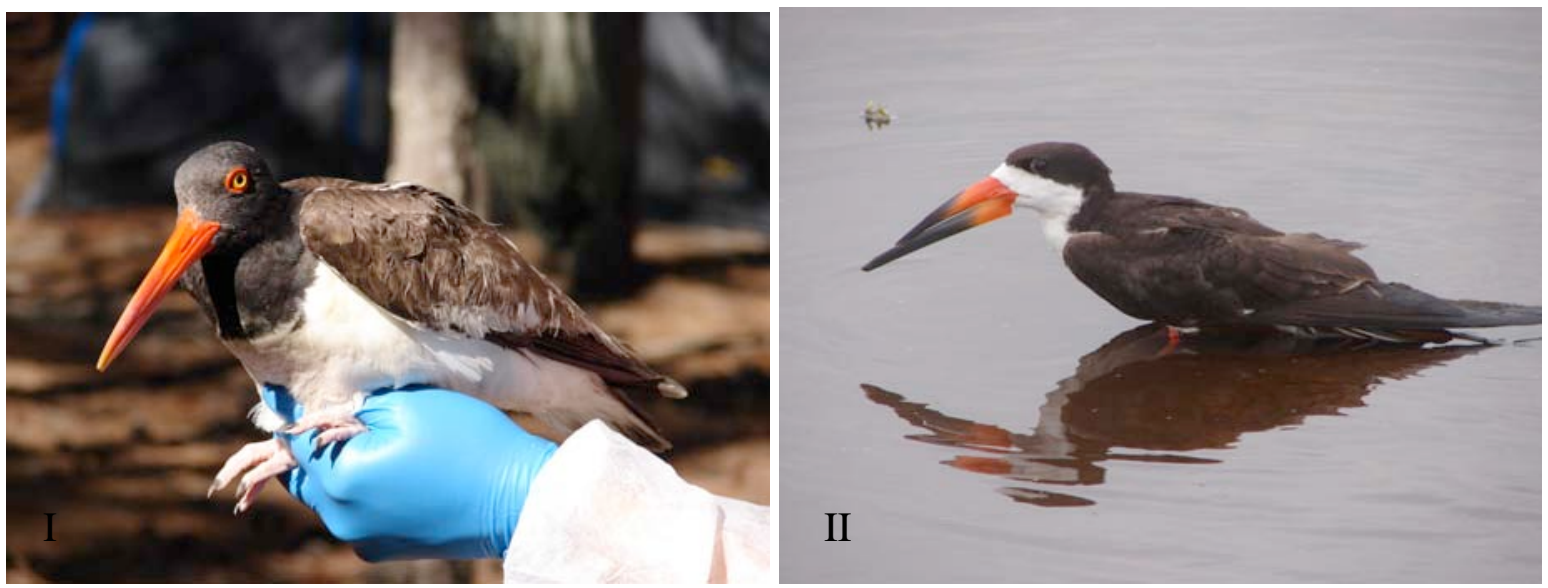

Figura 27 - Principais espécies capturadas na região: (I) Haematopus palliatus e (II) Rynchops niger.

Fonte: (EQUIPE DE CAMPO, 2013)

\subsubsection{Região urbanizada e litorânea - RS}

Concomitantemente a estas expedições, a equipe da Profa. Dra. Maria Virgínia Petry da Universidade do Vale do Rio dos Sinos (UNISINOS), realizou coleta de material de aves capturadas na região metropolitana de Porto Alegre (Tupandi, Feliz, Bom Princípio, São Leopoldo e Presidente Lucena), bem como de aves debilitadas e carcaças frescas de aves encontradas na região litorânea do município de Pinhal.
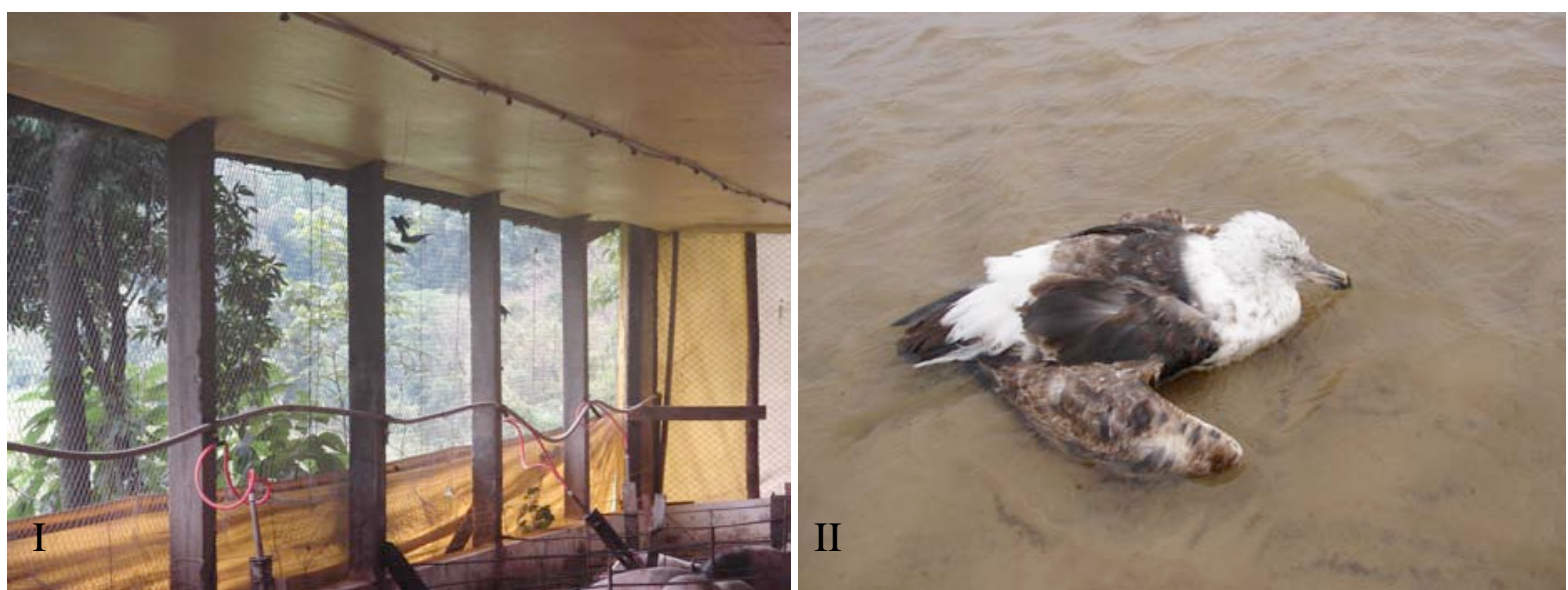

Figura 28 - (I) Aves silvestres atravessando a tela de proteção da granja e (II) Larus dominicanus moribundo à beira mar.

Fonte: (EQUIPE DE CAMPO, 2013) 
As cidades de Feliz, Tupandi, São Leopoldo, Presidente Lucena e Bom Princípio, são cidades que estão na região metropolitana de Porto Alegre, capital do estado do Rio Grande do Sul, a maior cidade do sul do Brasil. Áreas urbanizadas são caracterizadas por ambientes alterados devido à construção de edifícios e paisagens artificiais, entre outros elementos (ELTON; MILLER, 1954).

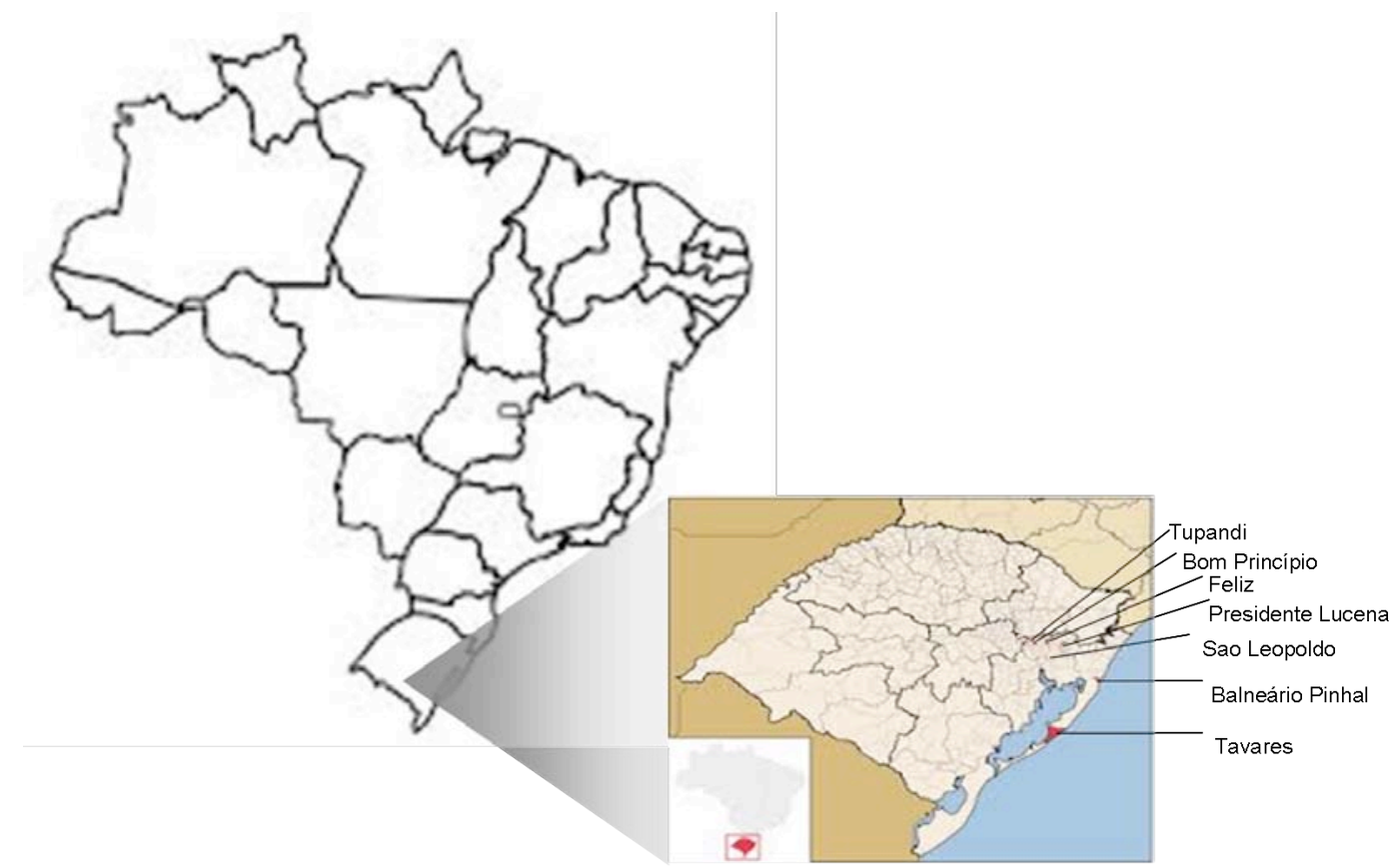

Figura 29 - Mapa de localização das amostras coletadas no Rio Grande do Sul.

Alguns pássaros são encontrados em locais urbanos para nidificação, alimentação e descanso. Já outras, espécies são adaptadas a viver em áreas urbanas (JOKIMAKI et al., 1996) sendo que as comunidades de aves urbanas são geralmente dominadas por espécies introduzidas (BEISSINGER; OSBORNE, 1982). No total foram coletadas 1286 amostras de aves entre os anos de 2008 a 2012.

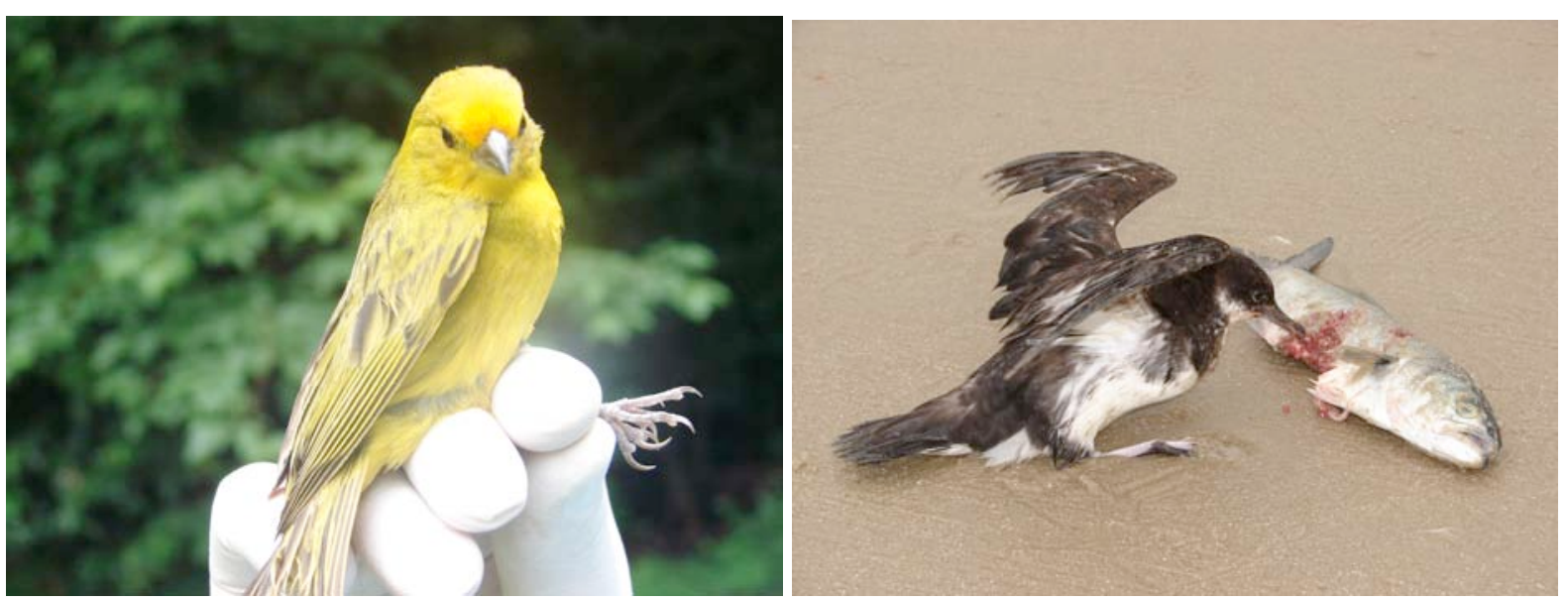

Figura 30 - Principais espécies capturada na região: (I) Sicalis flaveola e (II) Puffinus gravis. Fonte: (EQUIPE DE CAMPO, 2013) 
4.2.1.6 Centro de triagem de Animais Silvestres - SC

Ainda em parceria com o CEMAVE-ICMBio, em contato pré-estabelecido com a veterinária responsável, Patrícia Serafin, elaboramos um monitoramento viral de aves em recuperação no Centro de Triagem de Animais Silvestres (CETAS) localizado em Florianópolis - SC.

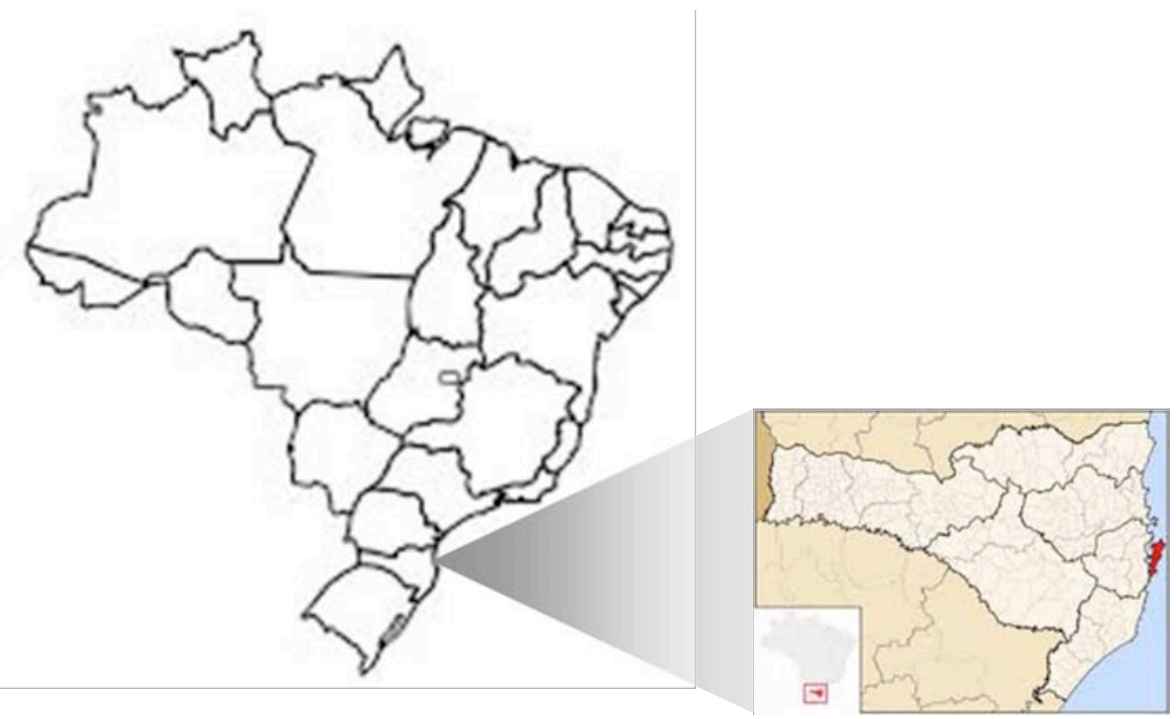

Figura 31 - Mapa de localização do CETAS.

Os CETAS tem a finalidade de recepcionar, triar e tratar os animais silvestres resgatados ou apreendidos pelos órgãos fiscalizadores, assim como eventualmente, receber animais silvestres de pessoas que os mantinham em cativeiro doméstico. Após serem examinados, os animais ficam em quarentena para receber nutrição adequada e sob observação, para identificar o aparecimento de possíveis doenças (IBAMA, 2013).

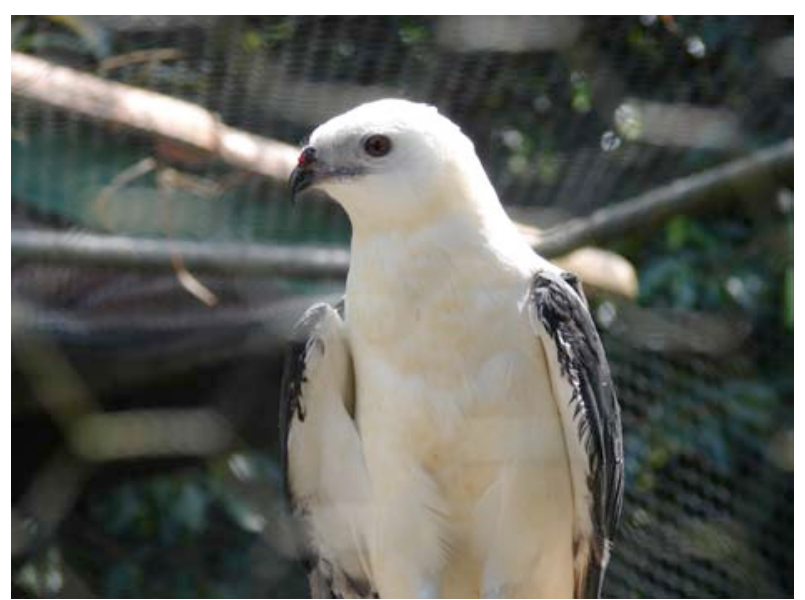

Figura 32 - Ave em recuperação no CETAS - SC.

Fonte: (EQUIPE DE CAMPO, 2013) 
Durante o primeiro semestre do ano de 2010 foi possível a coleta de 34 amostras de aves que chegaram ao CETAS de Florianópolis.

\subsubsection{Ilha de Fernando de Noronha - PE}

Também recebemos 42 amostras de aves coletadas na Ilha de Fernando de Noronha PE, em agosto e novembro de 2010. O arquipélago de Fernando de Noronha é dividido em Parque Nacional Marinho e Área de Proteção Ambiental. Cada área protege o meio ambiente para assegurar a preservação das espécies e a ocupação humana racional.

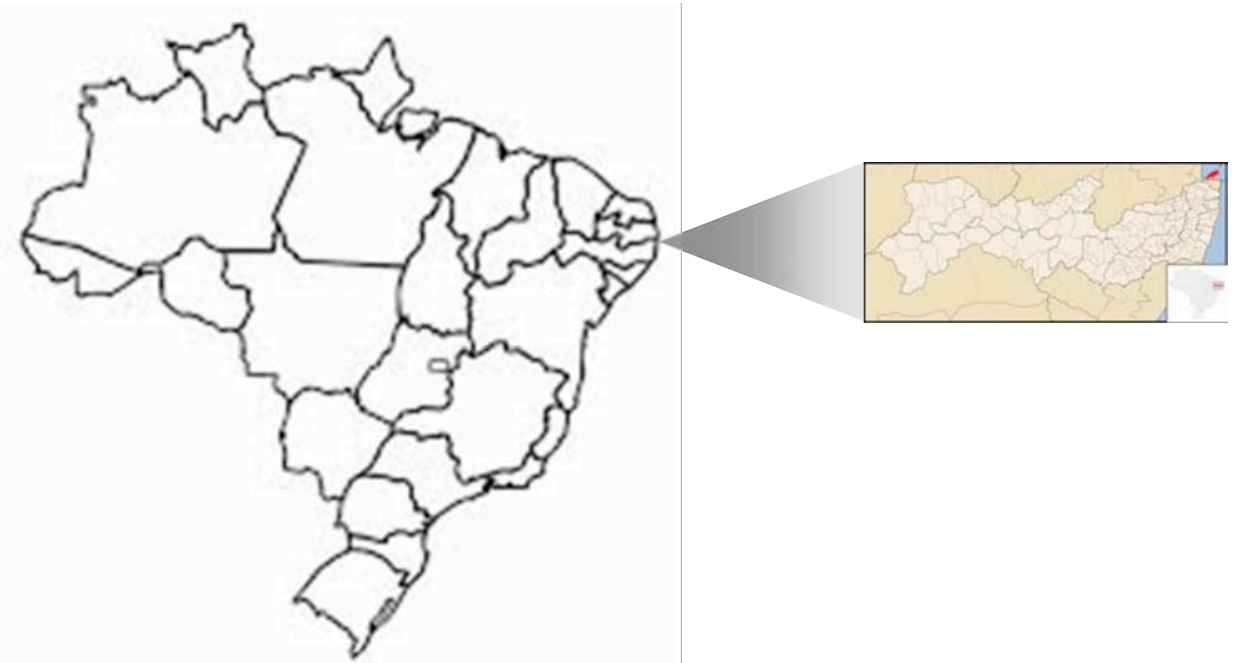

Figura 33 - Mapa de localização das amostras coletadas na Ilha de Fernando de Noronha.

Existem 40 espécies de aves registradas no arquipélago, que abriga as maiores colônias reprodutivas de aves marinhas entre as ilhas do Atlântico Sul. Com relação às aves, são consideradas migratórias de longo percurso e em geral provenientes do hemisfério norte. Essas aves chegam para descansar e se alimentar. São doze espécies de maçaricos e batuíras, sendo mais comum o vira pedra (Arenaria interpres) (PERNAMBUCO, 2011).

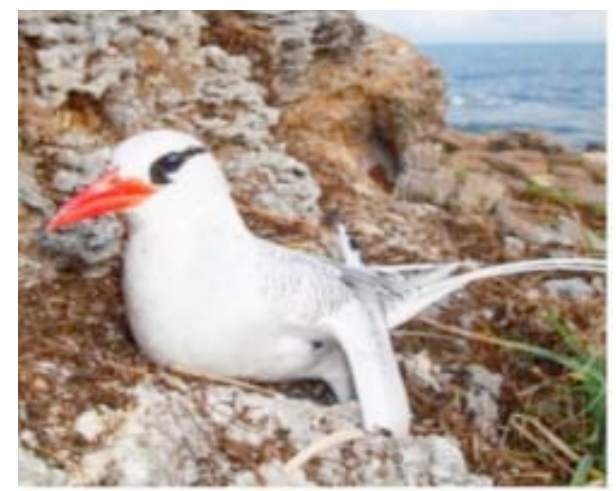

Figura 34 - Principal espécie capturada na região: rabo-de-palha-de-bico-vermelho (Phaethon aethereus) Fonte: (ICMBIO, 2013) 


\subsubsection{Reentrâncias Maranhenses - MA}

Em maio de 2010 também foi realizada expedição em nova área com o grupo do CEMAVE nas regiões da Ilha de Iguará, Ilha do Bate Vento, Guajurutiua e Ilha de Campechá, na região das Reentrâncias Maranhenses - MA.

A área de Proteção Ambiental Reentrâncias Maranhenses, no estado do Maranhão foi designada pelo Western Hemispheric Shorebird Reserve Network em 1991 como um local de importância internacional recebendo grandes populações de aves migratórias (RODRIGUES et al., 2009).

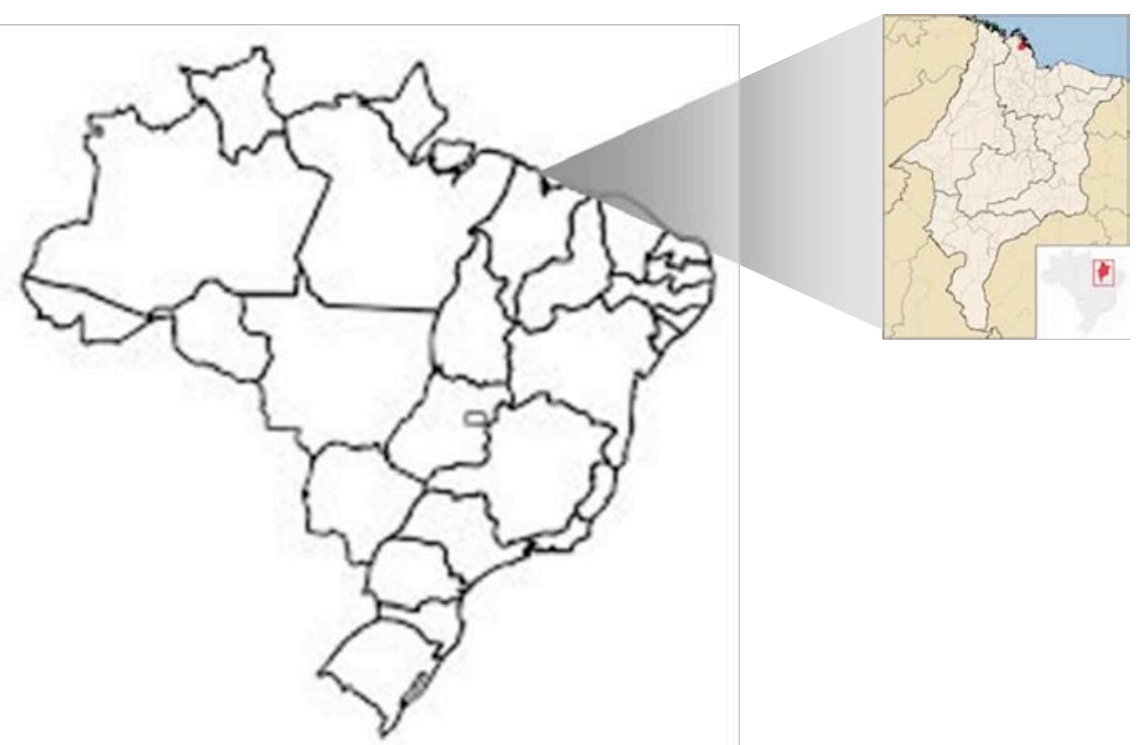

Figura 35 - Mapa de localização das amostras coletadas nas Reentrâncias Maranhenses.

Nas regiões de coleta de amostras de animais domésticos, pudemos amostrar animais silvestres que estão em cativeiro e muitas vezes foram trazidos pelos próprios donos, como ilustrado na figura a seguir.

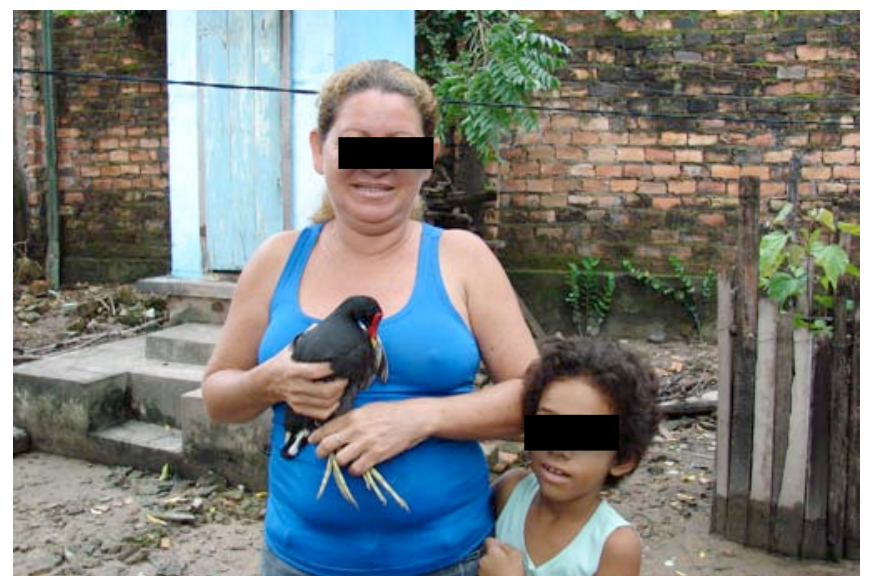

Figura 36 - Senhora trazendo seu animal de estimação (Gallinula chloropus) para a coleta de amostra.

Fonte: (EQUIPE DE CAMPO, 2013) 
Nesta região foi possível a coleta de 326 amostras de aves, dentre elas, anatídeos, como exemplificado a seguir.
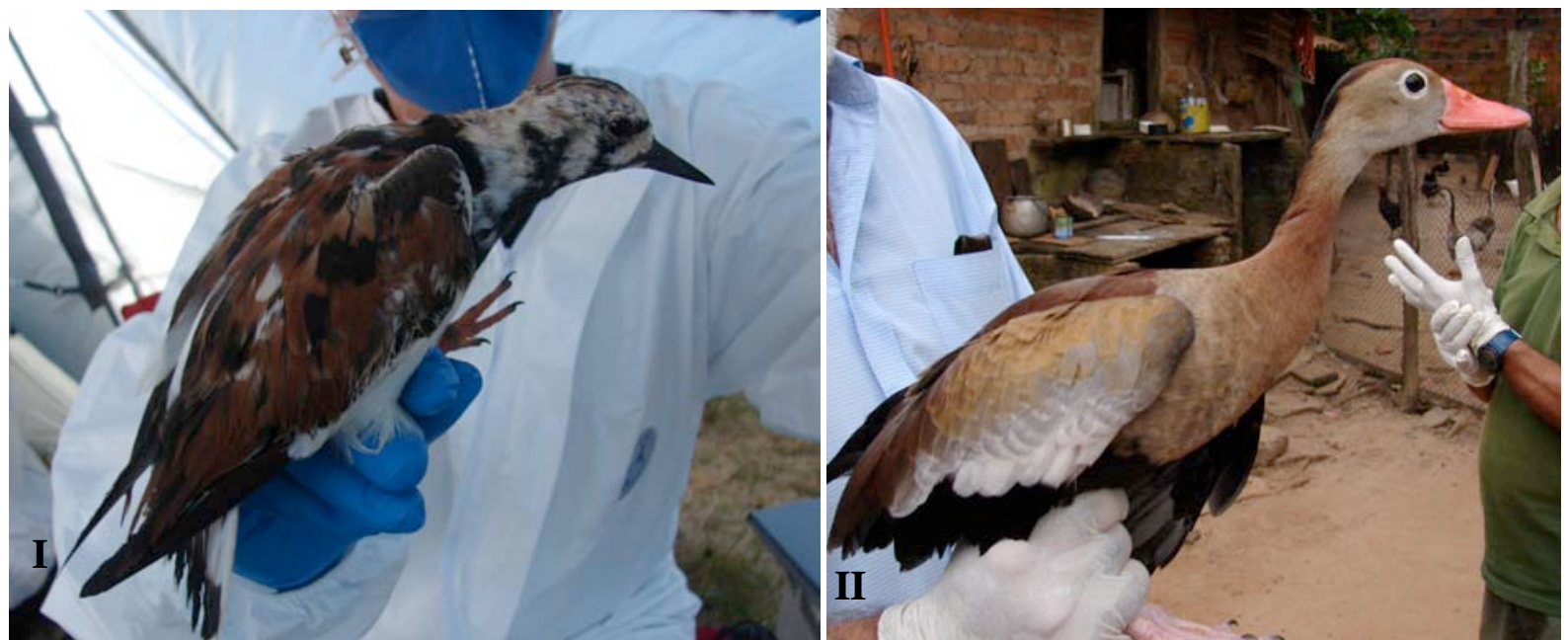

Figura 37 - Principais espécies capturadas na região: (I) Arenaria interpres e (II) Dendrocygna autumnalis

Fonte: (EQUIPE DE CAMPO, 2013)

\subsubsection{Pantanal - MT}

Em decorrência dos achados sorológicos deste estudo, direcionamos nossas atenções à região do Pantanal mato-grossense, local onde realizamos a expedição mais recente. Entre novembro e dezembro de 2012, fomos à região de Poconé em colaboração com a Universidade Federal do Mato Grosso, junto ao Prof. Dr. João Batista de Pinho do Laboratório de Ornitologia e sob a liderança do Prof. Dr. Daniel Moura de Aguiar do Laboratório de Virologia e Rickettsioses do Hospital Veterinário do Departamento de Clínica Médica Veterinária.

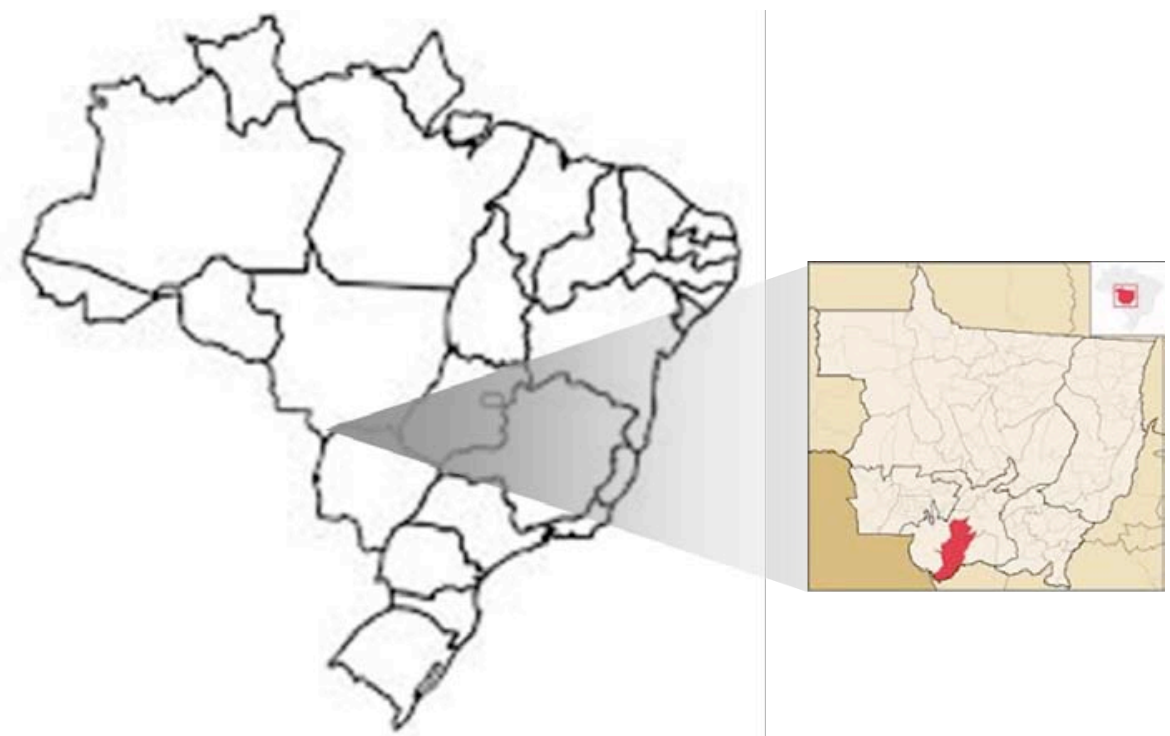

Figura 38 - Mapa de localização das amostras coletadas no Pantanal. 
Ficamos alojados em uma região próxima ao município de Poconé - MT, local onde o Instituto Nacional de Áreas Úmidas (INAU) possui ponto de apoio para trabalhos e pesquisas científicas, localizado na região do Pirizal.
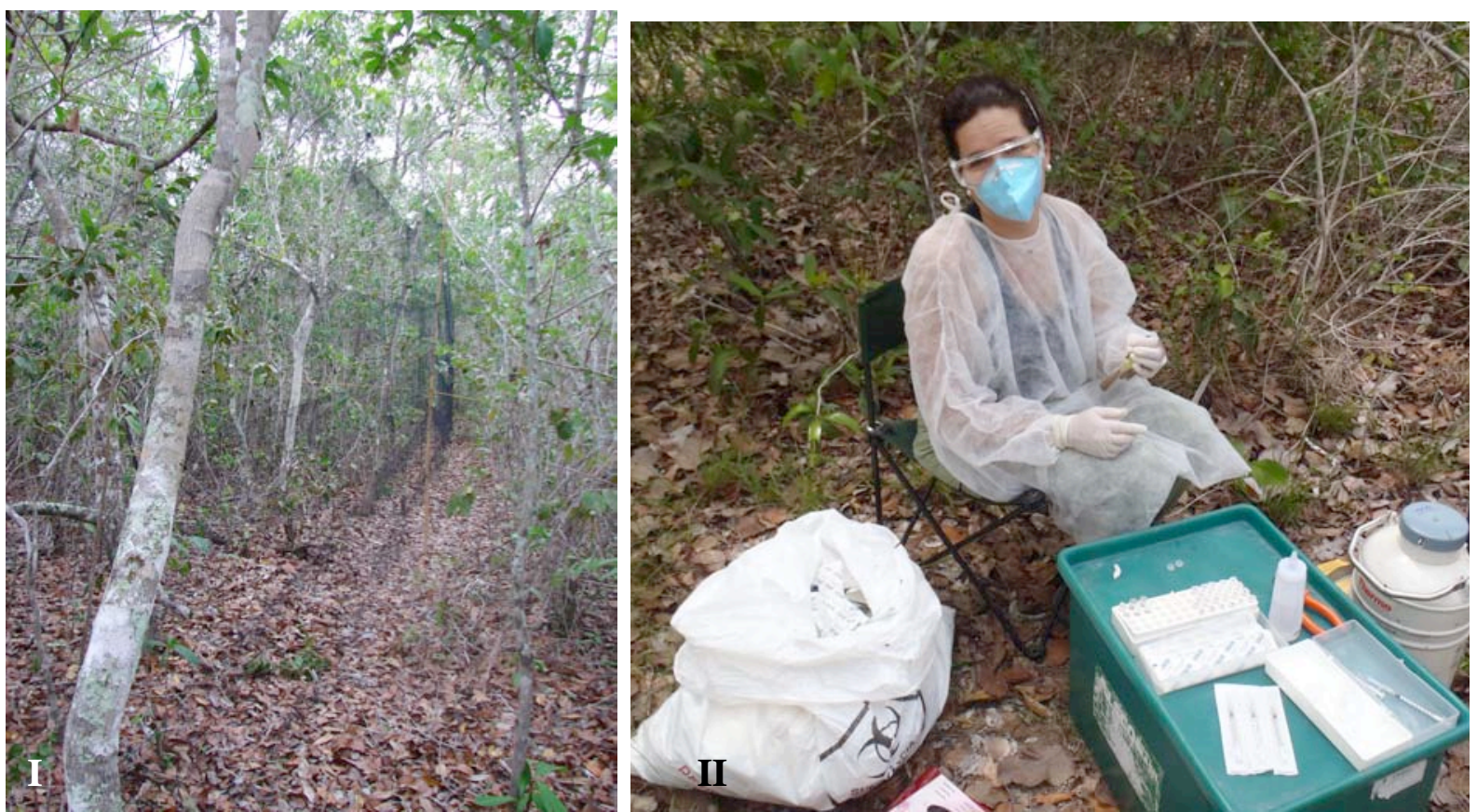

Figura 39 - (I) Rede de neblina armada e (II) coleta de material das aves no campo. Fonte: (EQUIPE DE CAMPO, 2013)

Nesta expedição foi possível a coleta de amostras de 157 aves silvestres migratórias, residentes e domésticas.
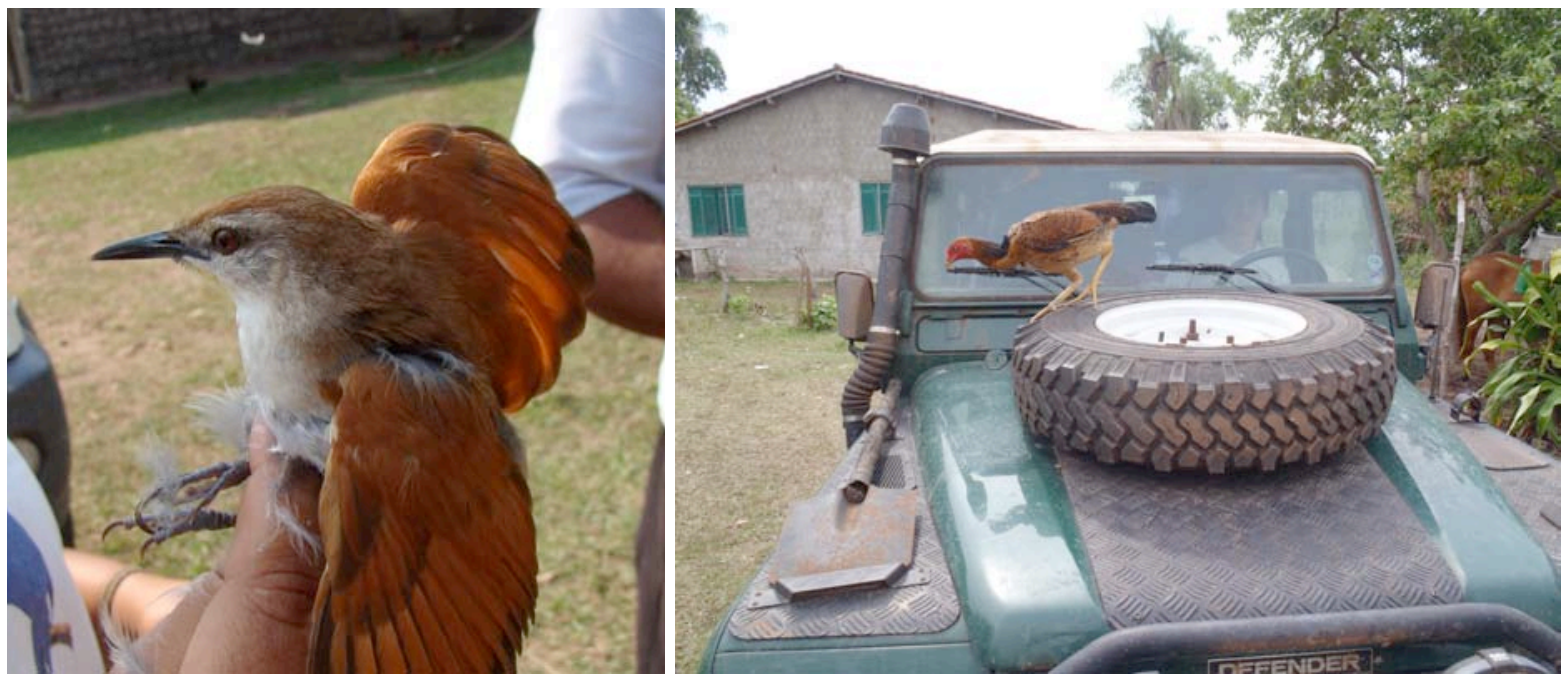

Figura 40 - Principais espécies capturadas na região: (I) Certhiaxis cinnamomeus e (II) Gallus gallus.

Fonte: (EQUIPE DE CAMPO, 2013) 


\subsubsection{Resumo Amostral de aves}

Após cinco anos de coleta de amostras de aves em diversos locais e biomas do território brasileiro foi possível alcançar o número amostral de 3.538 aves capturadas durante o estudo, conforme demonstrado na tabela a seguir. Informações detalhadas das coletas encontram-se no apêndice A.

Tabela 3 - Resumo do desenho amostral de aves e dados geográficos

\begin{tabular}{|c|c|c|c|c|c|}
\hline Local & Bioma & Data da Coleta & Amostras & Latitude & Longitude \\
\hline São Leopoldo - RS & Região Urbanizada & Out/08 & 37 & $29^{\circ} 45^{\prime} 38.80^{\prime \prime} \mathrm{S}$ & $51^{\circ} 09^{\prime} 07.80^{\prime \prime} \mathrm{W}$ \\
\hline Balneário Pinhal - RS & Litoral & Out/08 a Dez/10 & 540 & $30^{\circ} 15^{\prime} 38.95^{\prime \prime} \mathrm{S}$ & $50^{\circ} 14^{\prime} 19.57^{\prime \prime} \mathrm{W}$ \\
\hline Tupandi - RS & Região Urbanizada & Nov/08 a Mai/09 & 55 & $29^{\circ} 28^{\prime} 52.33^{\prime \prime} \mathrm{S}$ & $51^{\circ} 25^{\prime} 07.13^{\prime \prime} \mathrm{W}$ \\
\hline Feliz - RS & Região Urbanizada & Dez/08/a Jun/09 & 59 & $29^{\circ} 27^{\prime} 04.40^{\prime \prime} \mathrm{S}$ & $51^{\circ} 18^{\prime} 25.30^{\prime \prime} \mathrm{W}$ \\
\hline Bom Princípio - RS & Região Urbanizada & Jan/09 a Ago/09 & 141 & $29^{\circ} 29^{\prime} 28.28^{\prime \prime} \mathrm{S}$ & $51^{\circ} 21^{\prime} 30.41^{\prime \prime} \mathrm{W}$ \\
\hline Presidente Lucena - RS & Região Urbanizada & Set/09 & 20 & $29^{\circ} 31^{\prime} 00.54^{\prime \prime} \mathrm{S}$ & $51^{\circ} 10^{\prime} 40.92^{\prime \prime} \mathrm{W}$ \\
\hline Tavares - RS & Litoral & Set/10 a Abr/12 & 434 & $31^{\circ} 17^{\prime} 17.17^{\prime \prime} \mathrm{S}$ & $51^{\circ} 05^{\prime} 26.41^{\prime \prime} \mathrm{W}$ \\
\hline Glória - BA & Caatinga & Set/08 & 71 & $9^{\circ} 20^{\prime} 45.61 " \mathrm{~S}$ & $38^{\circ} 16^{\prime} 22.30^{\prime \prime} \mathrm{W}$ \\
\hline Coroa do Avião - PE & Ilha Oceânica & Out/08 & 18 & $7^{\circ} 48^{\prime} 59.82^{\prime \prime} \mathrm{S}$ & $34^{\circ} 50^{\prime} 21.40^{\prime \prime} \mathrm{W}$ \\
\hline Ilha de Canelas - PA & Amazônia & Nov/08 a Nov/10 & 1092 & $00^{\circ} 47^{\prime} 06^{\prime \prime} \mathrm{S}$ & $46^{\circ} 43^{\prime} 41^{\prime \prime} \mathrm{W}$ \\
\hline Parque Nacional da Lagoa do Peixe - RS & Pampa & Nov/09 a Nov/11 & 483 & $31^{\circ} 21^{\prime} 09.11^{\prime \prime} \mathrm{S}$ & $51^{\circ} 03^{\prime} 03.43^{\prime \prime} \mathrm{W}$ \\
\hline CETAS Florianópolis - SC & Ilha/Costa Oceânica & 2010 & 43 & $27^{\circ} 31^{\prime} 37.39^{\prime \prime} \mathrm{S}$ & $48^{\circ} 25^{\prime} 21.41^{\prime} \mathrm{W}$ \\
\hline Fernando de Noronha - PE & Ilha Oceânica & Ago/10 e Nov/10 & 52 & $3^{\circ} 50^{\prime} 44.08^{\prime \prime} \mathrm{S}$ & $32^{\circ} 24^{\prime} 31.49^{\prime \prime} \mathrm{W}$ \\
\hline Reentrâncias Maranhenses - MA & Baía/Enseada & Mai/10 & 326 & $2^{\circ} 30^{\prime} 42.80^{\prime \prime} \mathrm{S}$ & $44^{\circ} 28^{\prime} 32.94^{\prime \prime} \mathrm{W}$ \\
\hline Poconé - MT & Pantanal & Dez/12 & 157 & $16^{\circ} 15^{\prime} 12^{\prime \prime} \mathrm{S}$ & $56^{\circ} 22^{\prime} 12^{\prime \prime} \mathrm{W}$ \\
\hline
\end{tabular}

\subsubsection{Equídeos}

As regiões selecionadas seguem principalmente a localidade dos três casos reportados em 2006 na Argentina, como mostra a figura 41.

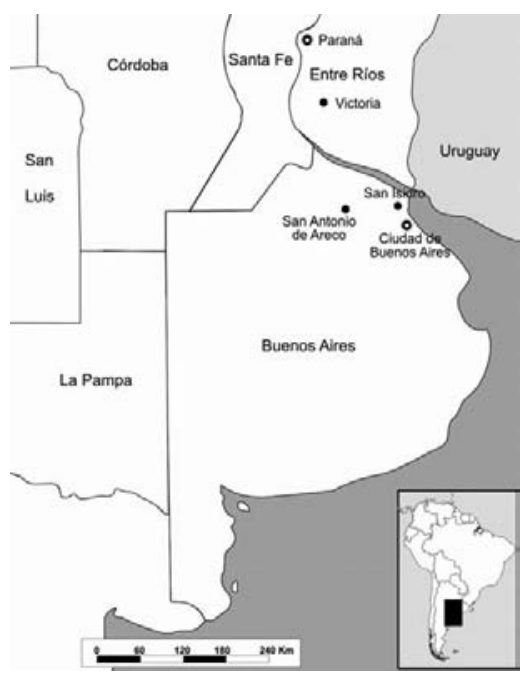

Figura 41 - Locais na Argentina onde foram reportados os isolamentos do WNV em cavalos. Fonte: (MORALES et al., 2006) 
Neste trabalho foram avaliados principalmente equídeos sadios, bem como aqueles que apresentassem sintomatologia sugestível de infecção por WNV. Foram contabilizadas 1307 amostras de equídeos, coletadas no período entre 2002 e 2012 em diversas regiões brasileiras.

\subsubsection{Monte Negro - RO}

As 99 amostras de soro de equídeos coletadas na cidade de Monte Negro - RO, que teve base no Instituto de Ciências Biomédicas V no ano de 2002, fazem parte do banco amostral da Dra. Guacyara Tenório do laboratório do Prof. Dr. Marcelo Labruna da Faculdade de Medicina Veterinária da Universidade de São Paulo (FMV-USP) e foram cedidas gentilmente para a realização deste estudo.

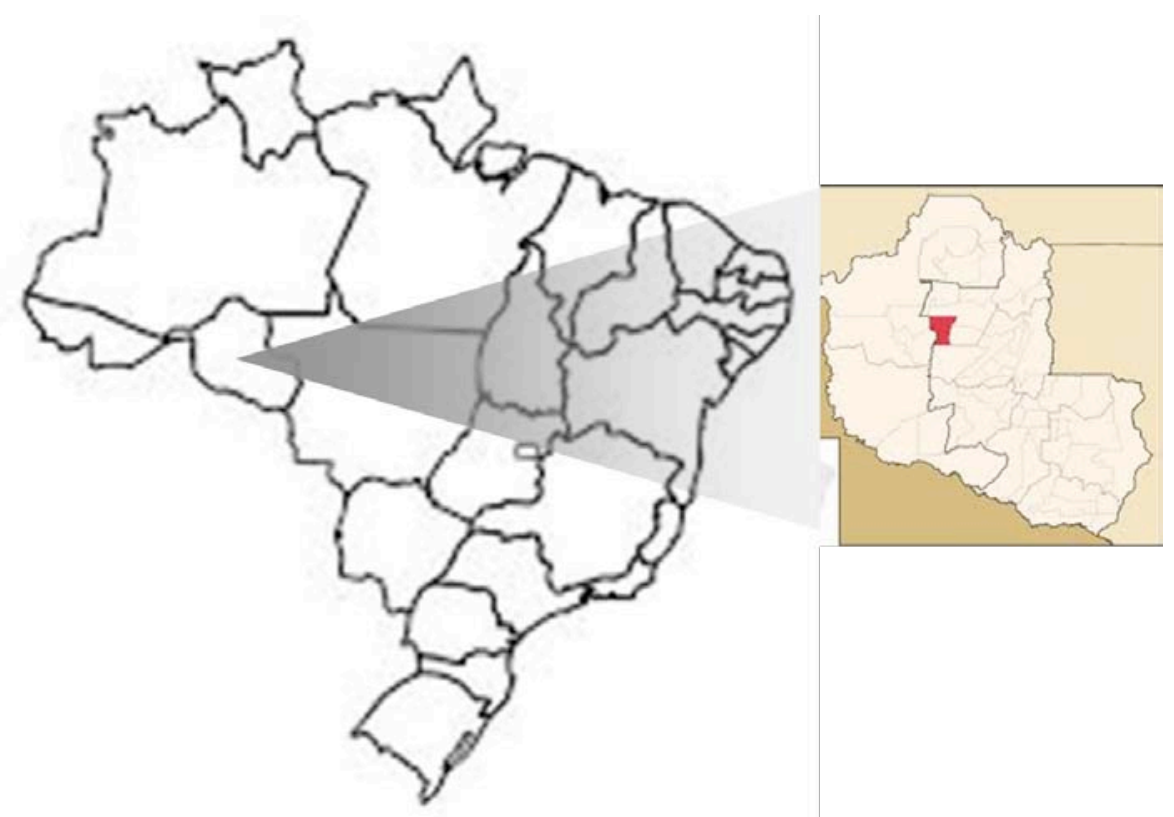

Figura 42 - Mapa de localização das amostras coletadas em Monte Negro.

A Amazônia é uma reserva ecológica de importância global que inclui um habitat ainda desconhecido, com grande biodiversidade de flora e fauna. Adicionando o intenso desmatamento que a região tem sofrido ao longo dos anos, ela pode propiciar a emergência e re-emergência de diferentes doenças ameaçadoras, como exemplo, as arboviroses (OLIVEIRA, 2002). 

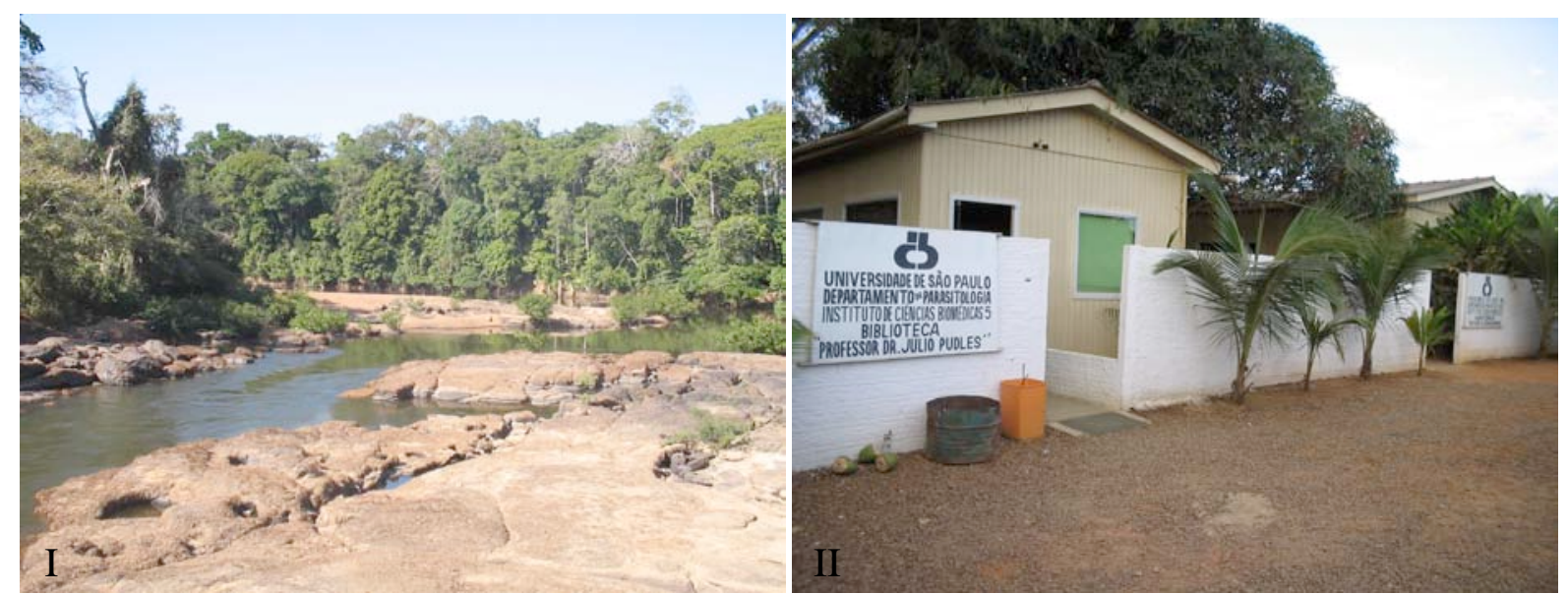

Figura 43 - (I) Imagem da região de Monte Negro - RO e (II) base de apoio do ICB V. Fonte: (EQUIPE DE CAMPO, 2013)

\subsubsection{Pontal do Paranapanema - SP}

A região do Pontal do Paranapanema compõe um quadro de 144 amostras de equídeos coletadas em 2008/2009, que fazem parte do banco amostral do Dr. Marcelo Schiavo Nardi da FMV-USP e Instituto de Pesquisa Ecológicas (IPÊ).

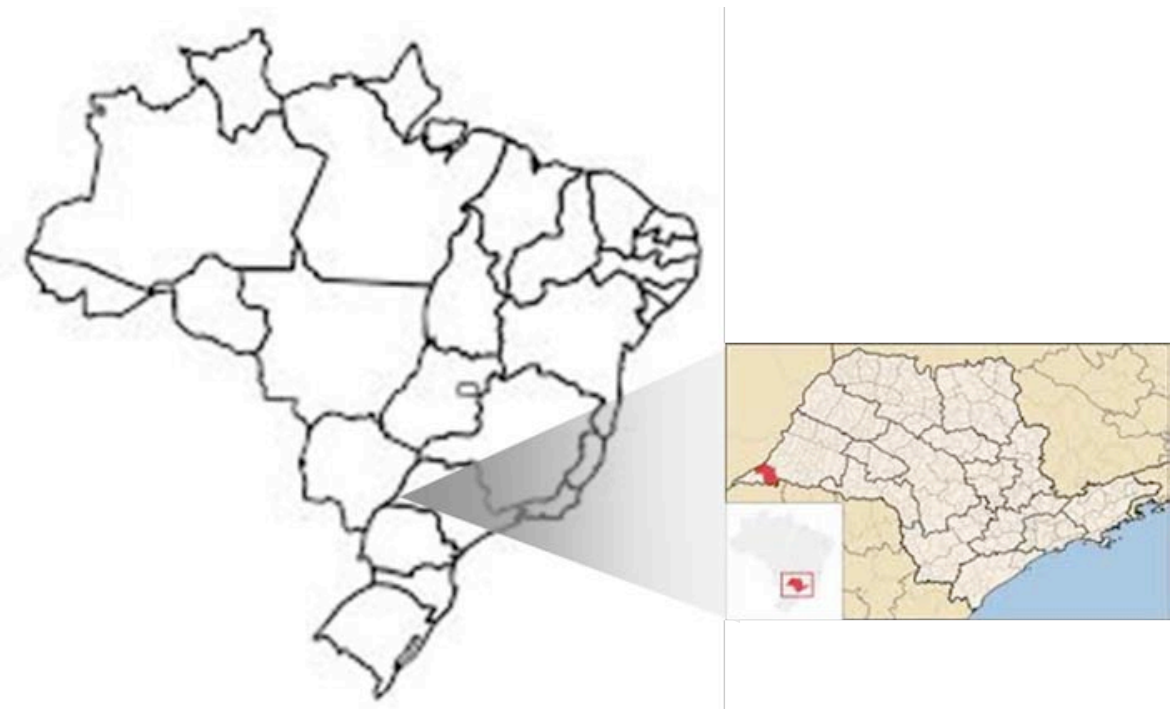

Figura 44 - Mapa de localização das amostras coletadas no Pontal do Paranapanema.

O Pontal do Paranapanema está situado a sudoeste do Estado de São Paulo, perto da confluência dos rios Paraná e Paranapanema, na divisa de São Paulo, Mato Grosso do Sul e Paraná. O parque do Pontal do Paranapanema, chamado Reserva Florestal do Morro do Diabo, sofreu ações destrutivas, como o desmatamento em chamas e invasão de posseiros ao longo de mais de 45 anos. A reserva agora chama-se Parque Estadual Morro do Diabo (PEMD) e está situada no município de Teodoro Sampaio (ALESSI et al., 2009). 

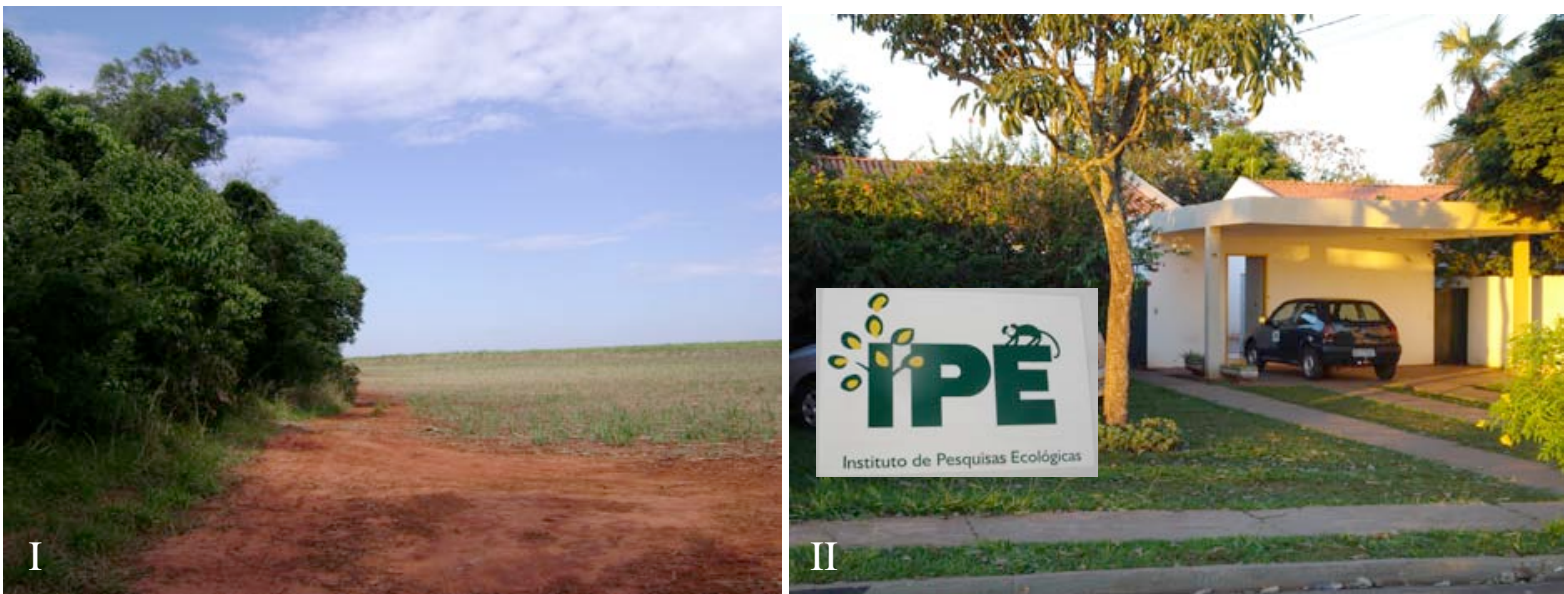

Figura 45 - (I) Imagem da região do Pontal do Paranapanema-SP e (II) base de apoio do IPÊ. Fonte: (EQUIPE DE CAMPO, 2013)

\subsubsection{Instituto Biológico - SP}

Em parceria com o Instituto Biológico de São Paulo (IB), acrescentamos 63 amostras de SNC de equídeos, gentilmente fornecidas por Dra. Eliana Villalobos, Dra. Elenice M. S. Cunha e Dra. Maria do Carmo C. S. H. Lara, do Centro de Pesquisa e Desenvolvimento de Sanidade Animal do Instituto Biológico de São Paulo.

As amostras são compostas por macerados de cérebro de 63 equídeos que morreram de encefalite e obtiveram resultados negativos para diversos microrganismos como para o vírus herpes, após três passagens em células RK13 e nested PCR. Também foram testados para o vírus da raiva por imunofluorescência direta e isolamento em camundongos, Encefalite Equina do Oeste e Leste também foram testadas em três passagens em células Vero e nested PCR, e finalmente, protozoários da família Sarcocystidae (toxoplasma e Neospora Sarcocystis) por nested PCR. Essas amostras foram coletadas entre 2008 e 2010 em São Paulo (49 amostras), Minas Gerais (4 amostras), Rio de Janeiro (2 amostras), Mato Grosso (2 amostras), Sergipe (2 amostras), Espírito Santo (1 amostra), Goiás (1 amostra), Paraíba (1 amostra) e Pernambuco (1 amostra).

\subsubsection{Pantanal - MT}

O estado do Mato Grosso compõe o maior número amostral de equídeos do estudo, com 994 amostras coletadas pelo grupo de pesquisa do Prof. Dr. Daniel Moura de Aguiar do Laboratório de Virologia e Rickettsioses do Hospital Veterinário do Departamento de Clínica Médica Veterinária da Universidade Federal do Mato Grosso (FAMEV - UFMT). 


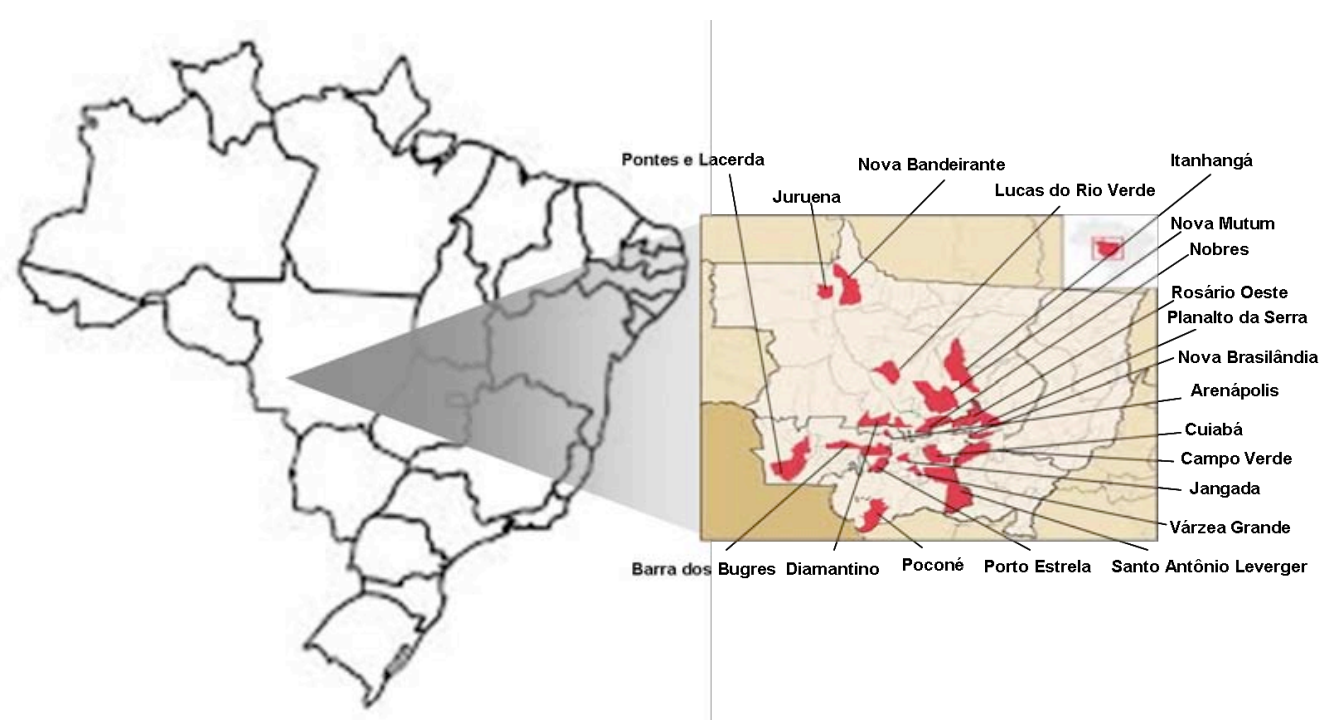

Figura 46 - Mapa de localização das amostras coletadas no estado do Mato Grosso.

É o terceiro maior estado do país, ficando atrás somente do Amazonas e do Pará. Um estado de proporções gigantescas com diversas regiões inabitadas. É um dos lugares com maior volume de água doce no mundo. Quanto aos biomas, Mato Grosso é um estado privilegiado em termos de biodiversidade, é o único do Brasil a ter, sozinho, três dos principais biomas do país: Amazônia, Cerrado e Pantanal (GOVERNO DO ESTADO DO MATO GROSSO, 2012).
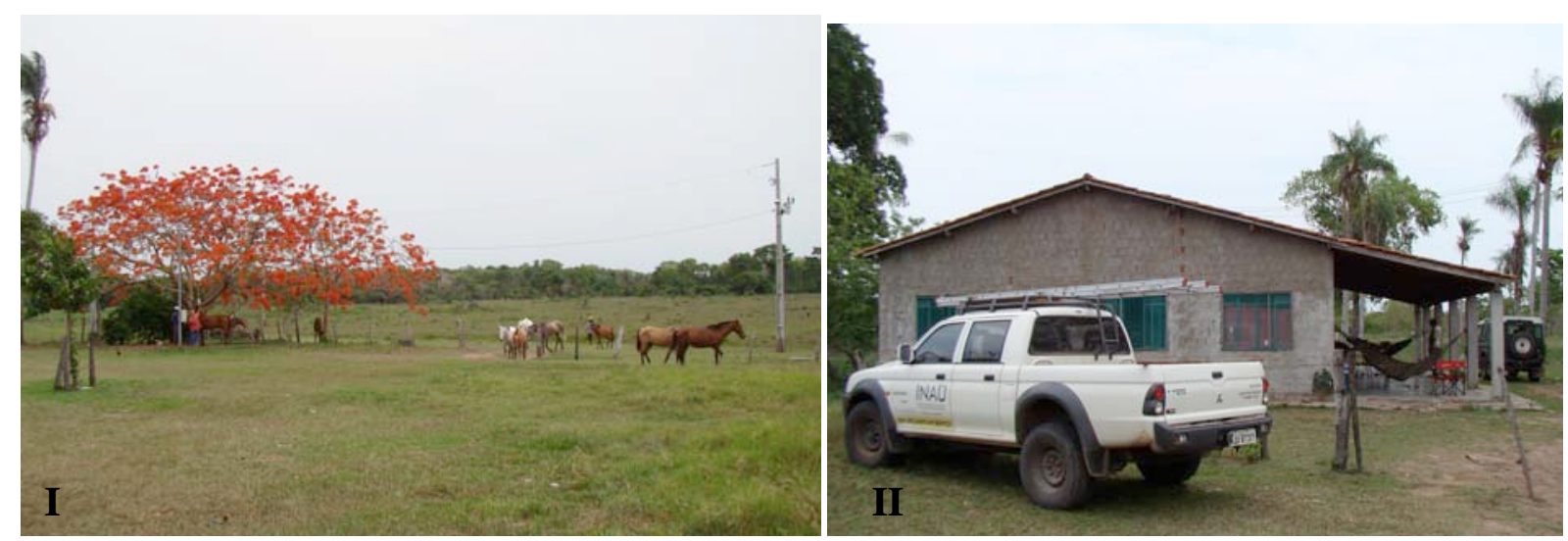

Figura 47 - (I) Imagem da região do Pirizal em Poconé - MT e (II) base de apoio do INAU. Fonte: (EQUIPE DE CAMPO, 2013)

Além das amostras do banco de soros de equídeos da UFMT, realizamos como última expedição científica deste estudo, a coleta de aves e equinos no Pantanal mato-grossense, como citado anteriormente, sendo coletados amostras de 7 equinos entre novembro e dezembro de 2012, na região do Pirizal - MT. 

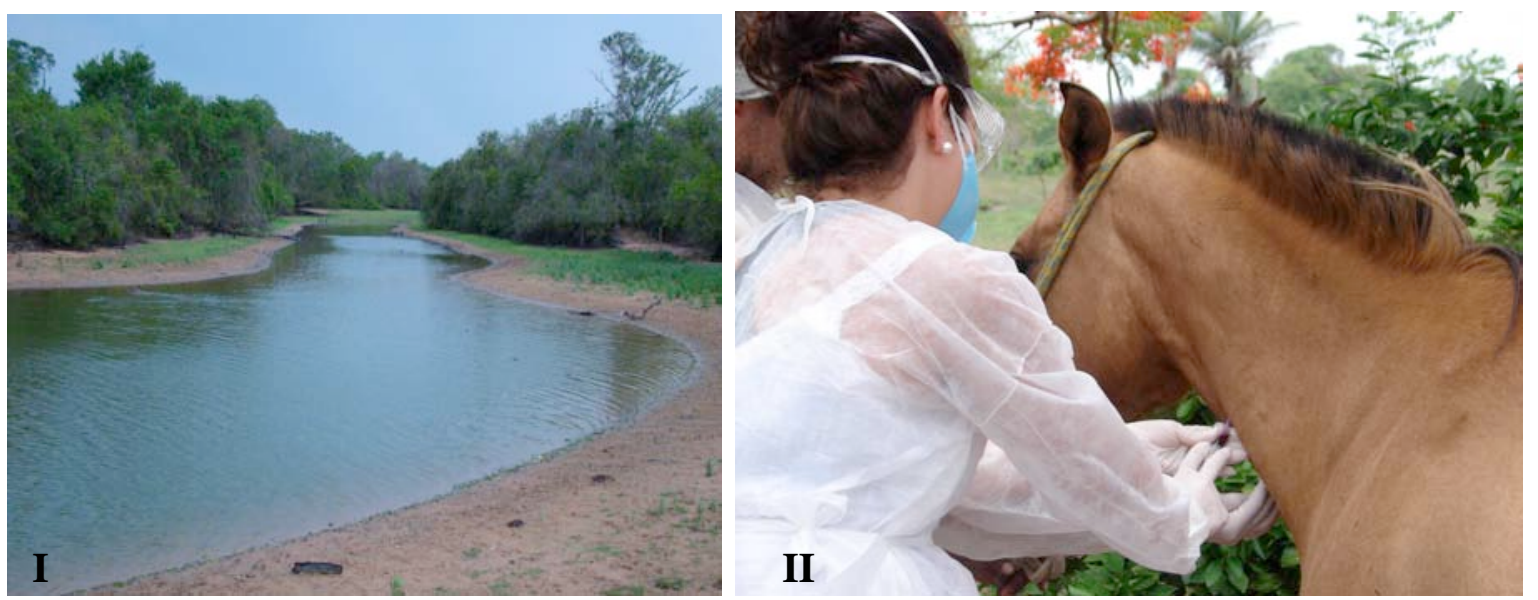

Figura 48 - (I) Região pantaneira e (II) coleta sanguínea de equino.

Fonte: (EQUIPE DE CAMPO, 2013)

\subsubsection{Resumo Amostral de equídeos}

Foi possível alcançar o número amostral de 1.307 equídeos coletados durante o estudo, conforme demonstrado na tabela a seguir. Informações detalhadas das coletas encontram-se no apêndice A.

Tabela 4 - Resumo do desenho amostral de equídeos e dados geográficos

\begin{tabular}{|c|c|c|c|c|c|}
\hline Local & Bioma & Data da Coleta & Total de amostras & Latitude & Longitude \\
\hline Monte Negro - RO & Amazônia & Nov/02 & 99 & $10^{\circ} 14^{\prime} 35,83^{\prime \prime} \mathrm{S}$ & $63^{\circ} 18^{\prime} 43,16^{\prime \prime} \mathrm{W}$ \\
\hline Pontal do Paranapanema - SP & Mata Atlântica & Maio/08 & 144 & $22^{\circ} 26^{\prime} 08,47^{\prime \prime} \mathrm{S}$ & $52^{\circ} 32^{\prime} 24,12^{\prime \prime} \mathrm{W}$ \\
\hline Nova Brasilândia - MT & Cerrado & Jan a Out/09 & 217 & $14^{\circ} 57^{\prime} 31,60^{\prime \prime} \mathrm{S}$ & $54^{\circ} 57^{\prime} 59,50^{\prime \prime} \mathrm{W}$ \\
\hline Juruena - MT & Amazônia & Nov/2009 & 218 & $12^{\circ} 50^{\prime} 50.03^{\prime \prime} \mathrm{S}$ & $58^{\circ} 55^{\prime} 36.84^{\prime \prime} \mathrm{W}$ \\
\hline Planalto da Serra - MT & Cerrado & Mar a Nov/09 & 146 & $14^{\circ} 39^{\prime} 23,74^{\prime \prime} \mathrm{S}$ & $54^{\circ} 46^{\prime} 17,58^{\prime \prime} \mathrm{W}$ \\
\hline Arenápolis -MT & Cerrado e Amazônia & Mar/09 & 3 & $14^{\circ} 27^{\prime} 02,11^{\prime \prime} \mathrm{S}$ & $56^{\circ} 50^{\prime} 08,96^{\prime \prime} \mathrm{W}$ \\
\hline Nova Bandeirantes - MT & Amazônia & Dez/09 & 58 & $9^{\circ} 57^{\prime} 19,62^{\prime \prime} \mathrm{S}$ & $57^{\circ} 51^{\prime} 59,09$ " W \\
\hline Santo Antônio Leverger - MT & Cerrado e Pantanal & Fev a Set/09 & 40 & $8^{\circ} 53^{\prime} 27,23^{\prime \prime} \mathrm{S}$ & $36^{\circ} 29^{\prime} 39,91$ ' W \\
\hline Jangada - MT & Cerrado & Mai a Ago/09 & 20 & $15^{\circ} 14^{\prime} 28,78^{\prime \prime} \mathrm{S}$ & $56^{\circ} 29^{\prime} 11,08^{\prime \prime} \mathrm{W}$ \\
\hline Nova Mutum - MT & Cerrado e Amazônia & Mar/09 & 39 & $13^{\circ} 50^{\prime} 18,57^{\prime \prime} \mathrm{S}$ & $56^{\circ} 04^{\prime} 50,88^{\prime \prime} \mathrm{W}$ \\
\hline Diamantino - MT & Cerrado e Amazônia & $\mathrm{Jul} / 09$ & 10 & $14^{\circ} 24^{\prime} 11,03^{\prime \prime} \mathrm{S}$ & $56^{\circ} 25^{\prime} 37,26^{\prime \prime} \mathrm{W}$ \\
\hline Lucas do Rio Verde - MT & Cerrado e Amazônia & Jun/09 & 76 & $13^{\circ} 03^{\prime} 48,12^{\prime \prime} \mathrm{S}$ & $55^{\circ} 55^{\prime} 15,72 ” \mathrm{~W}$ \\
\hline Campo Verde - MT & Cerrado & Mai/09 & 10 & $15^{\circ} 32^{\prime} 43,97^{\prime \prime} \mathrm{S}$ & $55^{\circ} 09^{\prime} 58,57^{\prime \prime} \mathrm{W}$ \\
\hline Poconé - MT & Pantanal & $\mathrm{Ou} / 09$ a Mar/10 & 70 & $16^{\circ} 15^{\prime} 25,39^{\prime \prime} \mathrm{S}$ & $56^{\circ} 37^{\prime} 28,74 " \mathrm{~W}$ \\
\hline Barra dos Bugres - MT & Cerrado e Amazônia & Mar/09 & 4 & $15^{\circ} 03^{\prime} 52.55^{\prime \prime} \mathrm{S}$ & $57^{\circ} 10^{\prime} 42.30^{\prime \prime} \mathrm{W}$ \\
\hline Porto Estrela - MT & Cerrado e Amazônia & Abr a Set/09 & 64 & $15^{\circ} 07^{\prime} 47.60^{\prime \prime} \mathrm{S}$ & $57^{\circ} 27^{\prime} 24.10^{\prime \prime} \mathrm{W}$ \\
\hline Itanhangá - MT & Amazônia & Out/09 & 6 & $12^{\circ} 10^{\prime} 49.96^{\prime \prime} \mathrm{S}$ & $56^{\circ} 37^{\prime} 01.00^{\prime \prime} \mathrm{W}$ \\
\hline Varzea Grande - MT & Cerrado e Pantanal & Set/09 & 1 & $15^{\circ} 38^{\prime} 52.06^{\prime \prime} \mathrm{S}$ & $56^{\circ} 07^{\prime} 59.47^{\prime \prime} \mathrm{W}$ \\
\hline Rosário Oeste & Cerrado & Fev/09 & 1 & $14^{\circ} 55^{\prime} 20.32^{\prime \prime} \mathrm{S}$ & $56^{\circ} 17^{\prime} 25.78^{\prime \prime} \mathrm{W}$ \\
\hline Pontes e Lacerda & Amazônia e Cerrado & Dez/09 & 4 & $15^{\circ} 14^{\prime} 03.27^{\prime \prime} \mathrm{S}$ & $59^{\circ} 19^{\prime} 52.07^{\prime \prime} \mathrm{W}$ \\
\hline Cuiabá & Região Urbanizada & Out/09 & 6 & $15^{\circ} 35^{\prime} 56.10^{\prime \prime} \mathrm{S}$ & $56^{\circ} 05^{\prime} 41.62 ” \mathrm{~W}$ \\
\hline Nobres & Cerrado & Fev/09 & 1 & $15^{\circ} 51^{\prime} 04.50^{\prime \prime} \mathrm{S}$ & $55^{\circ} 49^{\prime} 23.49^{\prime \prime} \mathrm{W}$ \\
\hline Instituto Biológico - SP & Não se aplica & 2008 a 2010 & 63 & - & - \\
\hline Poconé - MT & Pantanal & Dez/12 & 7 & $16^{\circ} 15^{\prime} 12^{\prime \prime} \mathrm{S}$ & $56^{\circ} 22^{\prime} 12^{\prime \prime} \mathrm{W}$ \\
\hline
\end{tabular}

A seguir, segue um mapa com o resumo amostral de aves e equídeos utilizado em todo o estudo, com descrição dos locais e indicação de biomas e estados. 


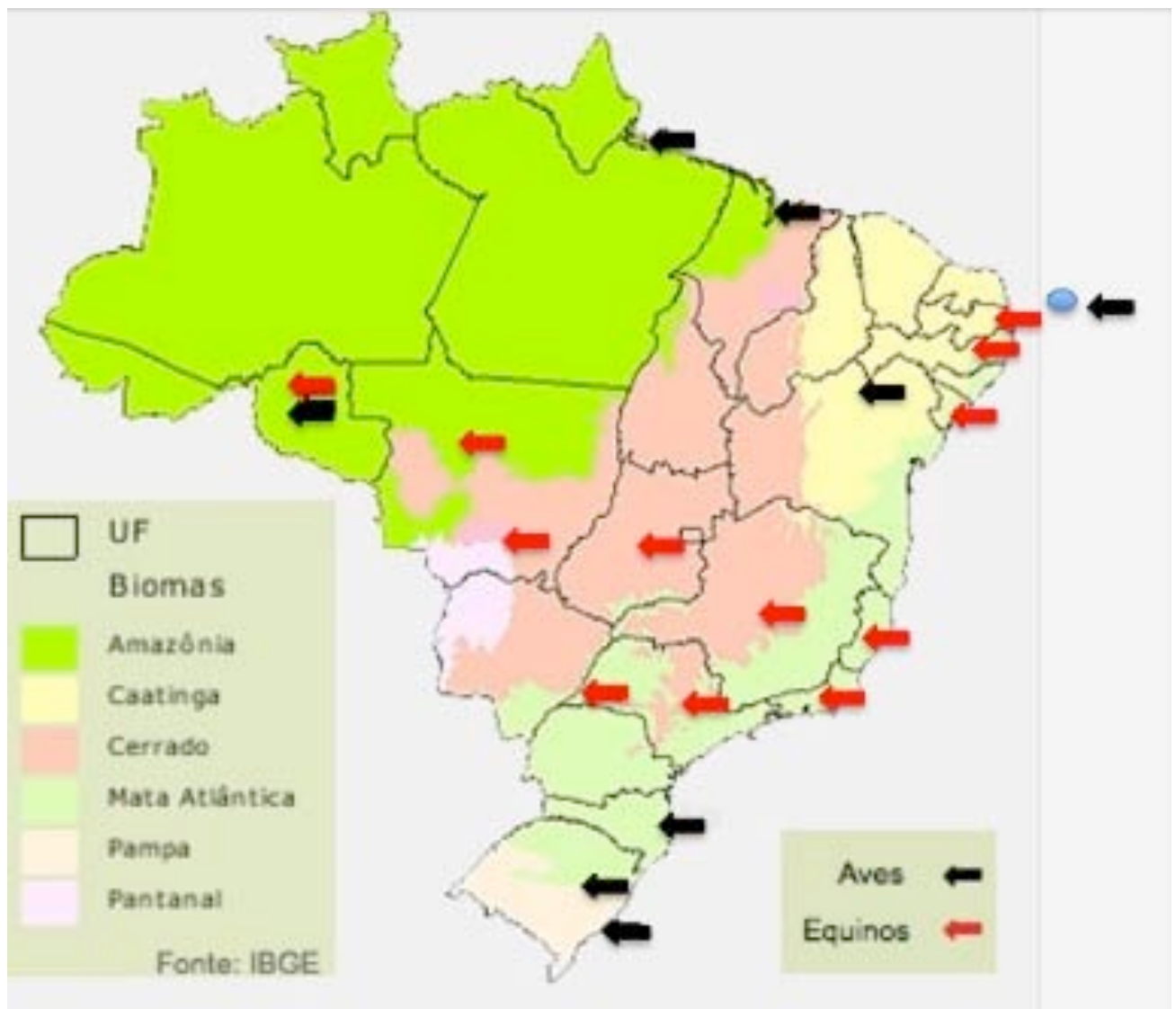

Figura 49 - Mapa com a distribuição de biomas e estados brasileiros com locais das coletas.

\subsubsection{Outros animais}

$\mathrm{Na}$ expedição realizada no ano de 2012 no Pantanal mato-grossense, também foi possível a coleta de amostras biológicas de sangue e swabs de morcegos que estavam abrigados em uma casa abandonada próxima ao local de coleta das aves.
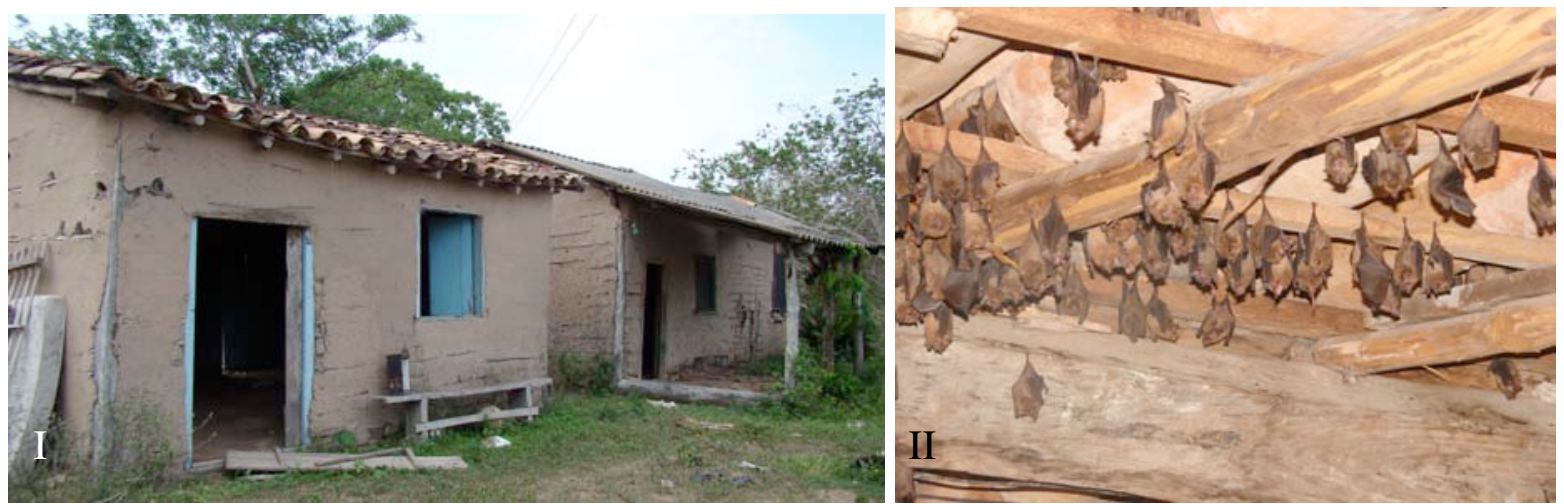

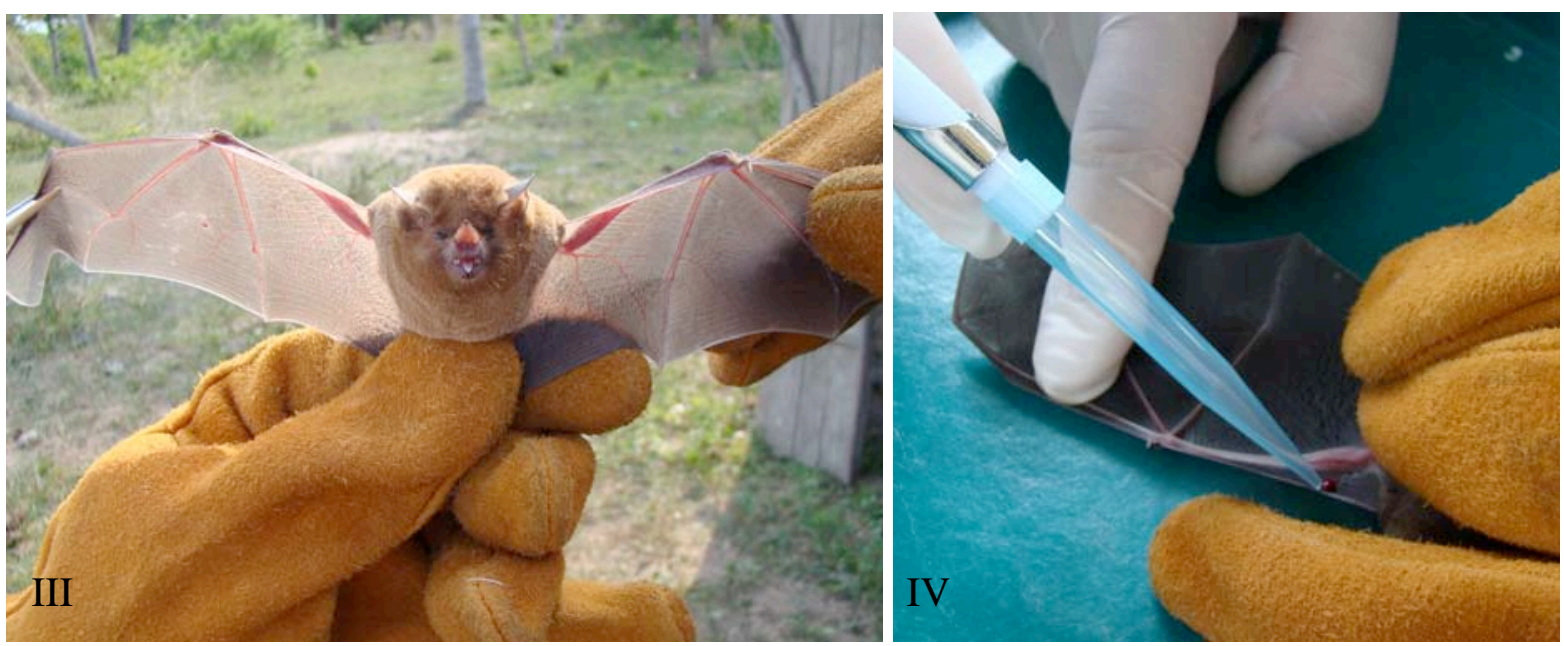

Figura 50 - (I) Casa abandonada, (II) morcegos alojados no teto do local, (III) manejo e identificação e (IV) coleta sanguínea.

Fonte: (EQUIPE DE CAMPO, 2013)

Também em parceria com o Prof. Dr. Daniel de Moura Aguiar da UFMT, somamos à amostragem do Pantanal mato-grossense, amostras biológicas de soros de onças coletadas na região, provenientes da dissertação de mestrado de sua aluna, Selma Onuma.

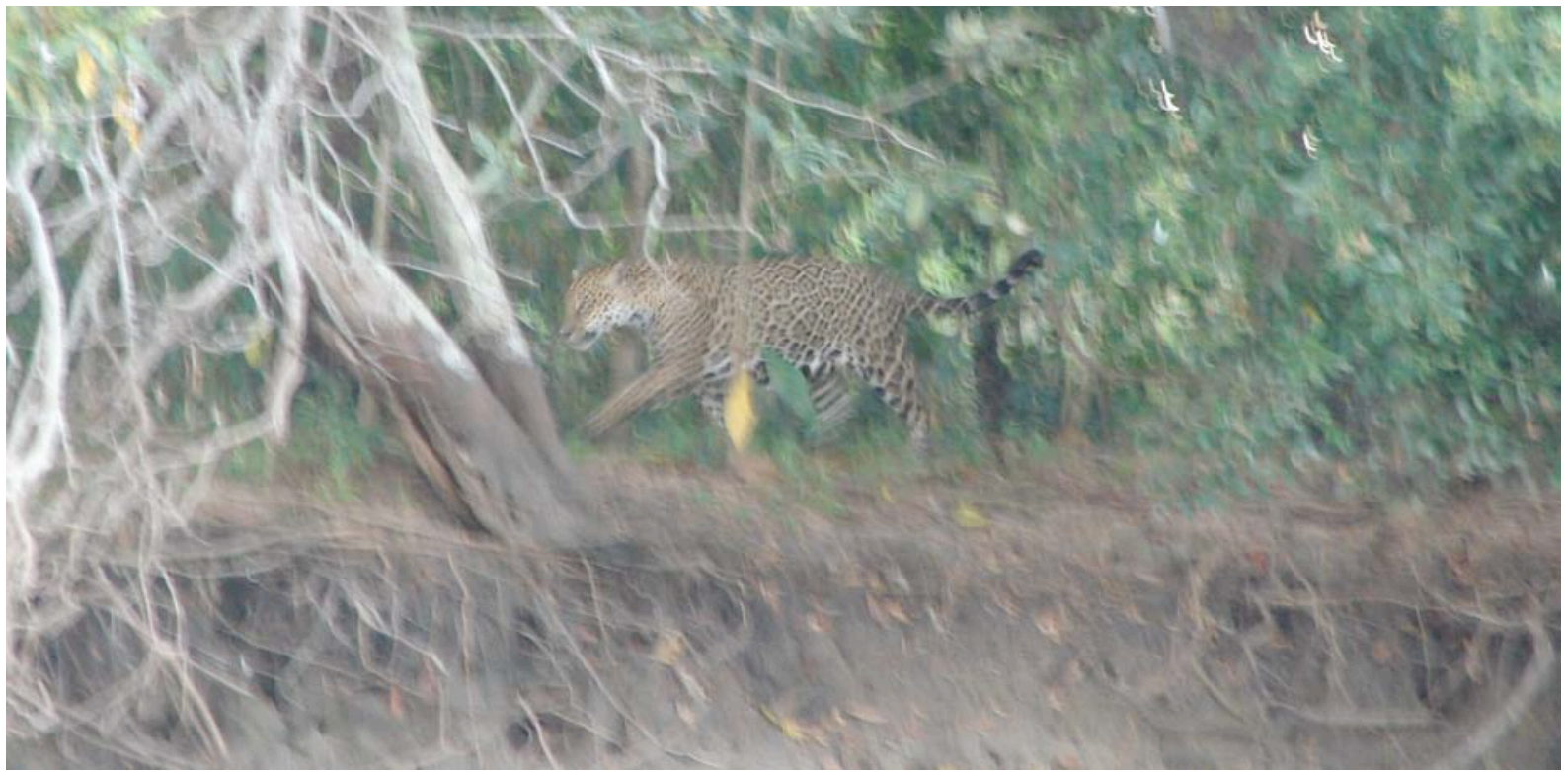

Figura 51 - Panthera onça

Fonte: Arquivo pessoal

\subsection{CAPTURA DAS AVES E COLETA DAS AMOSTRAS BIOLÓGICAS}

Levando em consideração a dificuldade em se trabalhar com amostras de animais silvestres e o aparato necessário para se locomover até as regiões mais inóspitas para a captura dos animais e a coleta de material (THOMAZELLI et al., 2012), apresento abaixo a estrutura de campo do Laboratório de Virologia Clínica e Molecular do ICB II, composta 
principalmente por: dois carros, uma Land Rover Defender 110 e uma F350 adaptadas para tal uso, equipamentos de camping e equipamentos e materiais laboratoriais.

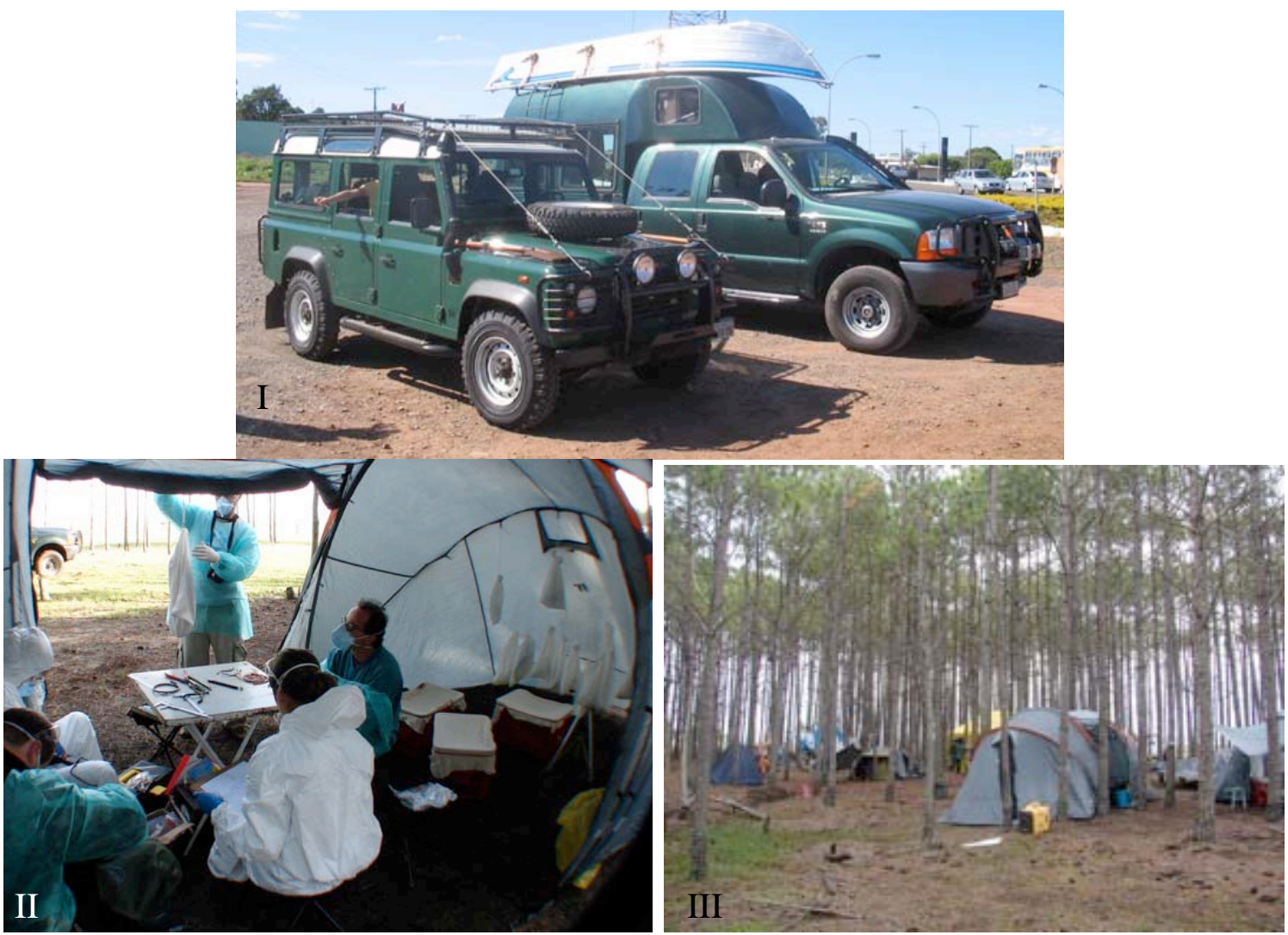

Figura 52 - (I) Carros utilizados nas expedições, (II) estrutura ornitológica para biometria e identificação, e (III) acampamento.

Fonte: (EQUIPE DE CAMPO, 2013)

Os procedimentos de captura estão de acordo com as resoluções da Comissão de Ética em Experimentação Animal do ICB - USP.

Como citado anteriormente, para a captura de passeriformes e outras aves de pequeno porte, foram utilizadas redes de neblina. Com uso de equipamentos de proteção individual (EPI) específicos para evitar possíveis contaminações do pesquisador, do animal e da amostra, os procedimentos de biometria, identificação, coleta sanguínea, swabs traqueal e cloacal/anal, foram realizados no campo, próximo ao local de captura, em estrutura montada especialmente para este fim. Logo após a coleta, as amostras foram acondicionadas imediatamente em nitrogênio líquido, e as aves soltas no mesmo local de captura.

\subsubsection{Colocação das redes}

As redes foram armadas em pontos estratégicos determinados após a observação da localização e comportamento das aves, sendo ocasionalmente remanejadas, se necessário. 


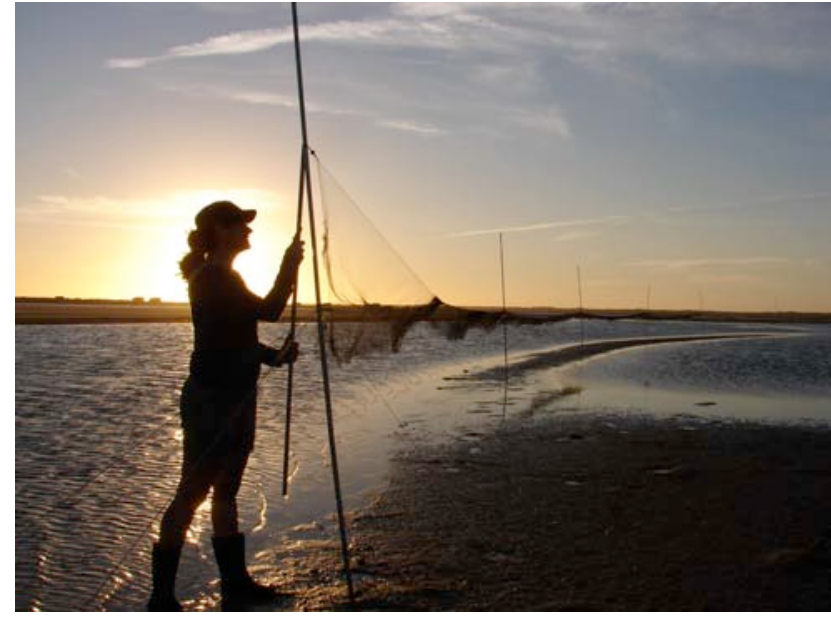

Figura 53 - Montagem das redes de neblina Fonte: (EQUIPE DE CAMPO, 2013)

\subsubsection{Retirada de animais das redes}

A cada uma ou duas horas, dependendo do número de animais capturados, parte da equipe realizava vistoria nas redes para recolhimento dos animais. Esse procedimento era realizado com total cuidado para não machucar os animais, que imediatamente eram levados ao acampamento para identificação, biometria, coleta de sangue, swab traqueal/cloacal e a subsequente soltura.

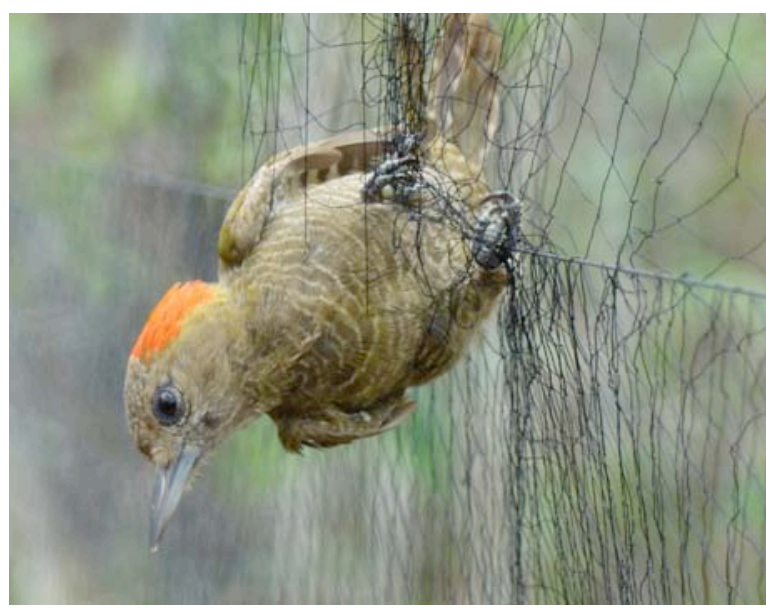

Figura 54 - Ave presa na rede de neblina.

Fonte: (EQUIPE DE CAMPO, 2013)

\subsubsection{Biometria e identificação}

O processo de identificação e biometria requer certo conhecimento ornitológico e habilidade, assim, os especialistas do CEMAVE, da UFRPE, UNISINOS e UFMT realizavam o trabalho de medição e tabulação das informações em planilhas que contém dados biológicos 
de status (ave nova, recaptura, recuperação), idade (adulto, jovem, ninhego, indeterminado), identificação (plumagem, crânio, cor dos olhos, outros), sexo, (macho, fêmea, indeterminado), método (plumagem, cloaca, cor dos olhos, outros), plumagem (jovem $1^{\circ}$ ano, sub-adulto, adulto eclipse, ou intermediário e reprodução) além das medidas asa, tarso, cauda, narina ponta e peso.

A necessidade de conhecimento das informações acima se dá como fator fundamental para identificação da fauna e do entendimento do fator de risco de disseminação de doenças que esses animais podem ser para outros animais e pessoas. As aves foram identificadas e anilhadas pelo grupo, facilitando a identificação nas recapturas, bem como acompanhamento da migração das mesmas. A coleta de informações teve como objetivo conhecer melhor as espécies capturadas, auxiliar na determinação da quantidade de sangue a ser coletada, além de definir em que fase de desenvolvimento estes animais se encontravam, auxiliando na discussão epidemiológica dos possíveis achados virais.
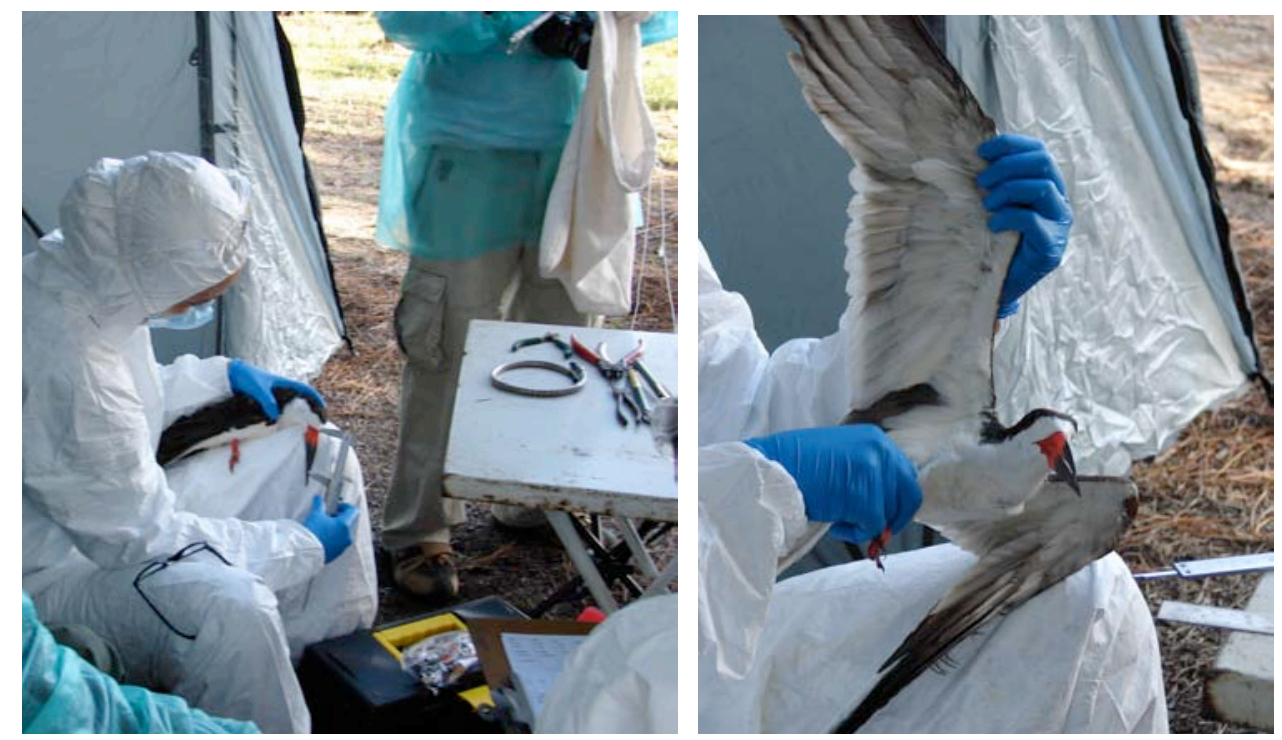

Figura 55 - (I) Biometria e (II) identificação da ave.

Fonte: (EQUIPE DE CAMPO, 2013)

\subsubsection{Coleta de swab traqueal e cloacal}

Decidimos realizar a coleta de $s w a b$ traqueal e cloacal como método padrão do estudo, pois seria o melhor custo benefício de coleta de material com suficiente carga viral para detecção e por ser um método menos invasivo e manteríamos o mesmo padrão amostral nas espécies capturadas. A coleta sanguínea para teste molecular no soro das aves, demonstra maior carga viral na maioria dos dias, porém é um método extremamente invasivo, e que muitas vezes não é passível de coleta em animais de pequeno porte ou debilitados, ao 
contrário da coleta de penas, que apesar de ser muito menos invasivo, apresenta baixa carga viral na detecção molecular, como demonstra a figura a seguir.

(a) NS2a RNA in sera

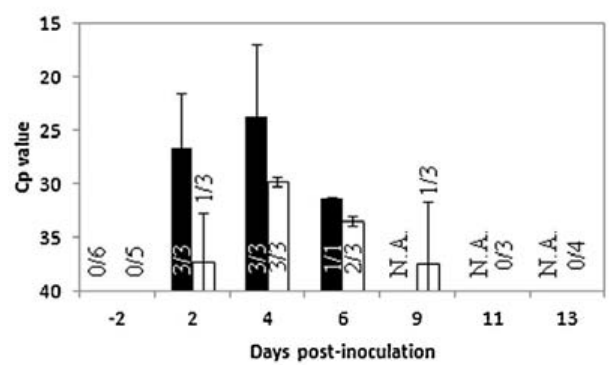

(c) NS2a RNA in feathers

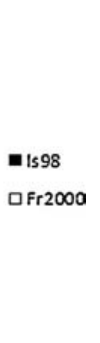

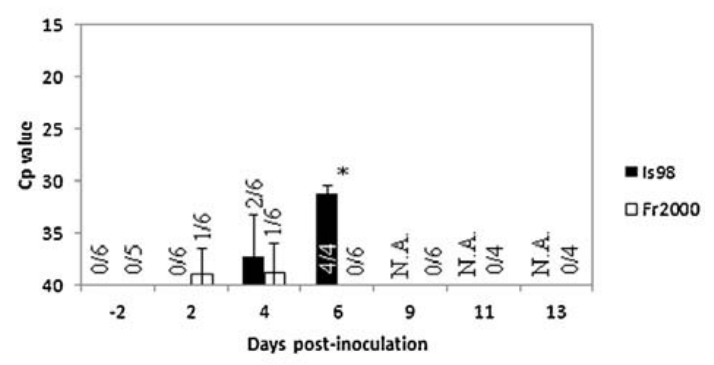

(b) NS2a RNA in oral swabs

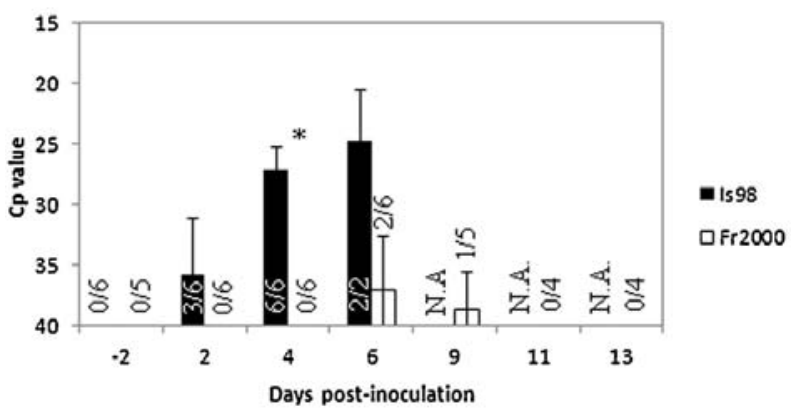

Figura 56 - Carga viral no soro (a), swab oral (b) e penas (c), dias após a infecção estimada por NS2a-specific rRT-PCR em corvos juvenis inoculados experimentalmente com as estirpes Is98 (barras pretas) e Fr2000 (barras brancas) de WNV.

Fonte: (DRIDI et al., 2013)

Após a identificação e biometria das aves, foram coletados $s w a b$ traqueal e cloacal em duplicata. O material foi conservado em $500 \mu \mathrm{L}$ de meio de transporte, que é composto por solução salina (PBS) estéril (Cultilab, São Paulo, Brasil), $20 \mu \mathrm{L}$ de BSA (Albumina Bovina) (Cultilab), 10\% Glicerol (50 $\mu \mathrm{L})$ (Sigma-aldrich, St. Louis, USA), Penicilina/Streptomicina 4 $\mu \mathrm{L}(10.000 \mathrm{u} / \mu \mathrm{L})$ (Sigma-aldrich) e Anfotericina B $(250 \mathrm{U} / \mathrm{ml}) 1 \mu \mathrm{L}$ (Sigma-aldrich), e imediatamente acondicionados em nitrogênio líquido, ainda no local de coleta.
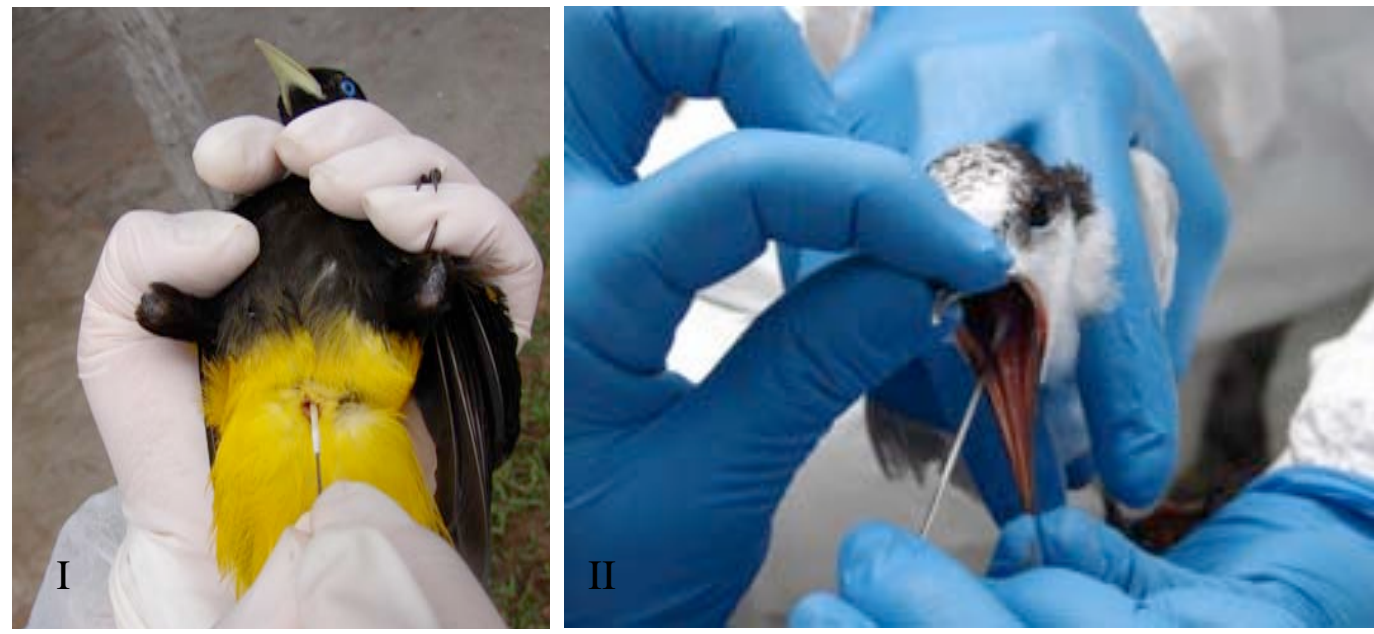

Figura 57 - (I) Coleta de swab cloacal e (II) swab traqueal.

Fonte: (EQUIPE DE CAMPO, 2013) 


\subsubsection{Coleta sanguínea}

Foi coletado sangue das aves na quantidade de até $1 \%$ do peso vivo das mesmas, preferencialmente da veia jugular ou asa, dependendo do porte da ave em questão.
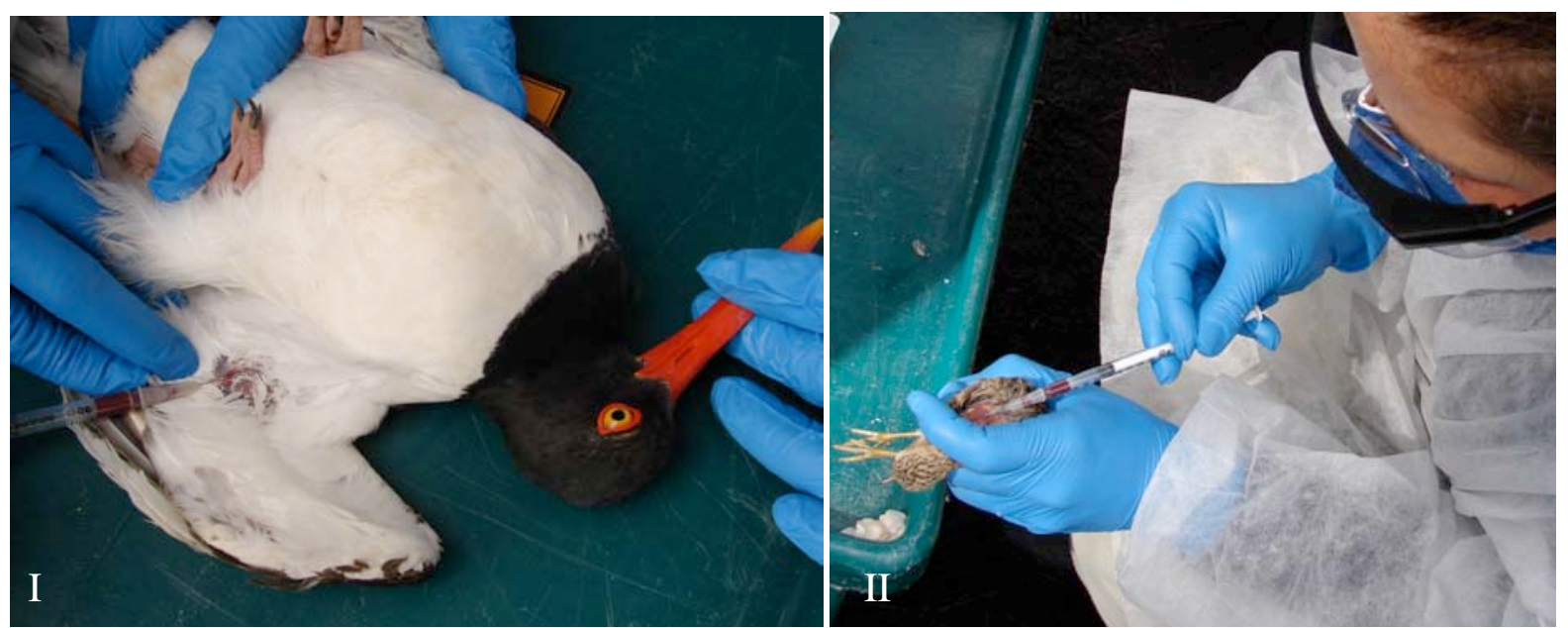

Figura 58 - (I) Coleta sanguínea em animais de médio porte, (II) coleta sanguínea de animais de pequeno porte.

Fonte: (EQUIPE DE CAMPO, 2013)

Imediatamente após a coleta das amostras biológicas as aves foram soltas e as amostras armazenadas em nitrogênio líquido, ainda em campo.

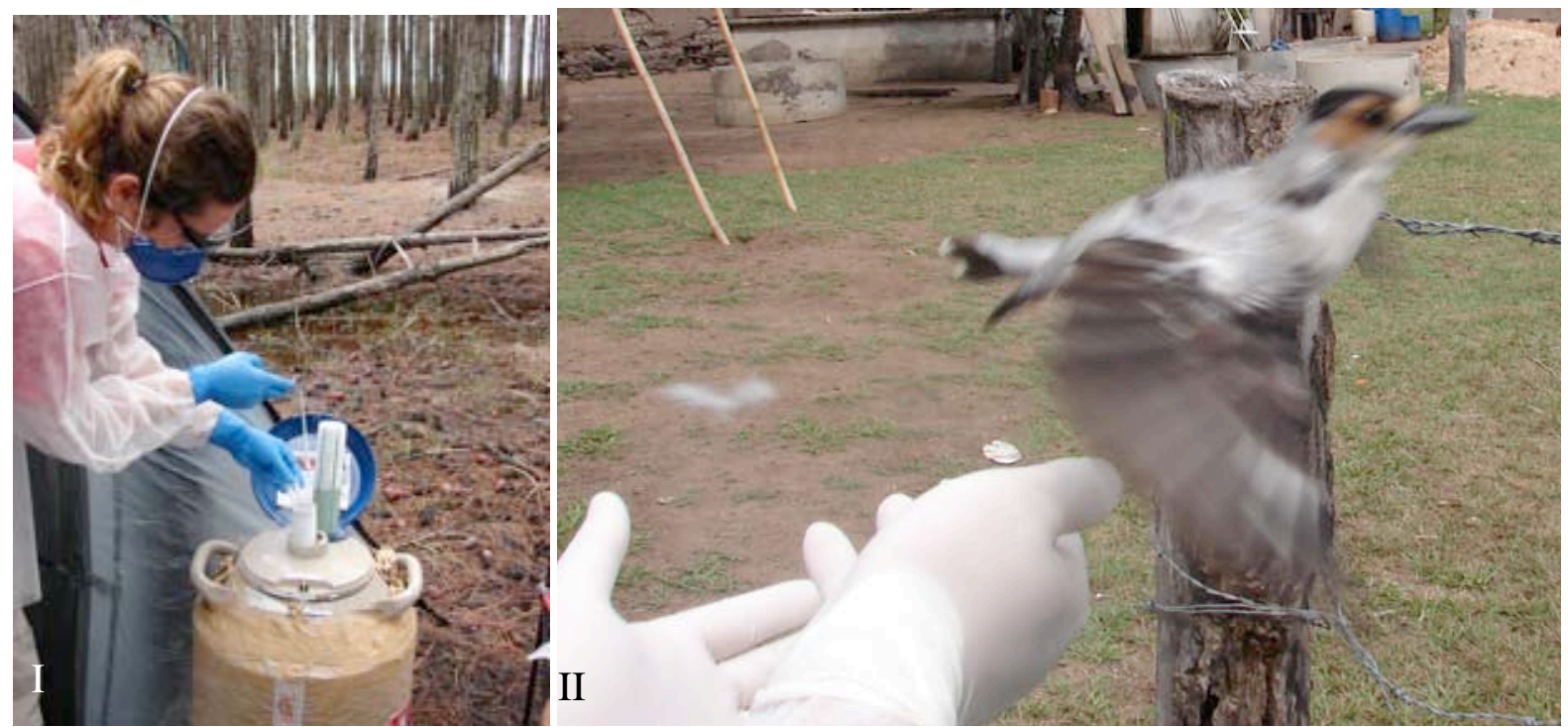

Figura 59 - (I) Amostras armazenadas em nitrogênio líquido no campo e (II) soltura da ave. Fonte: (EQUIPE DE CAMPO, 2013)

O sangue foi acondicionado em tubos herméticos identificados com a numeração da amostra e após a coagulação com a separação do coágulo e soro, a amostra foi centrifugada, evidenciando a separação das duas fases, quando então foi coletado o soro e acondicionado em criotubos secos, para serem imediatamente armazenados em nitrogênio líquido. 

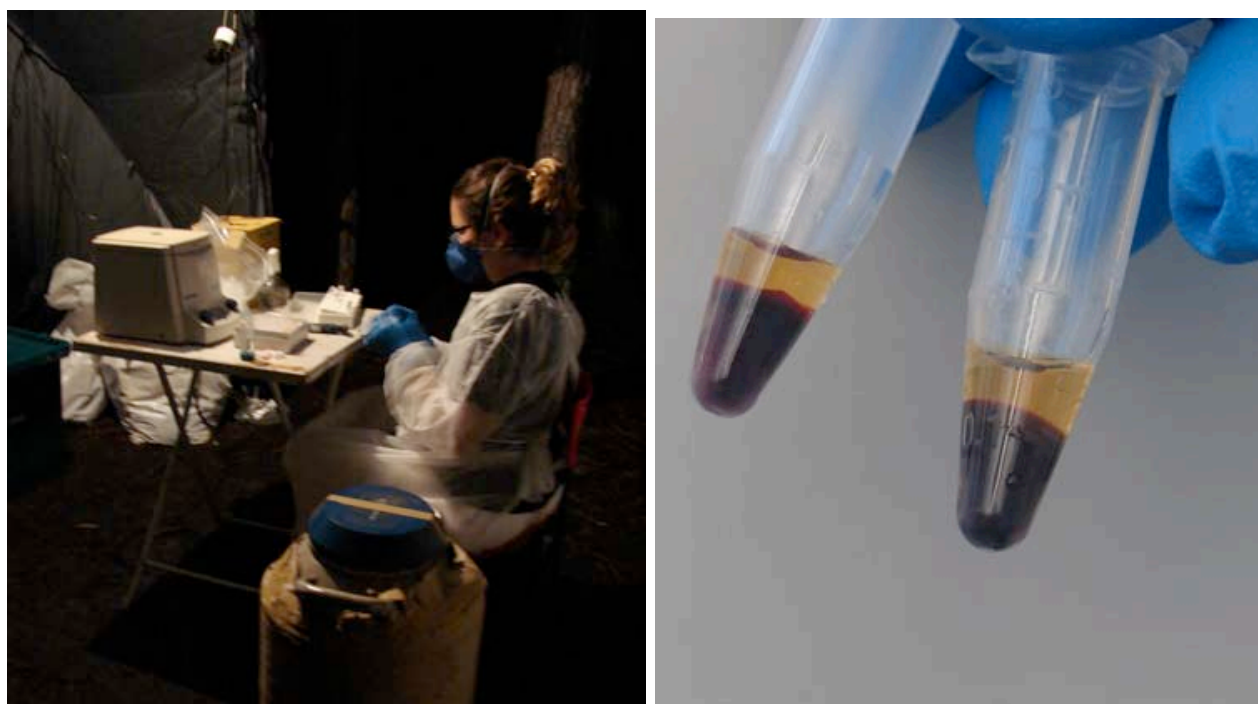

Figura 60 - (I) trabalho laboratorial noturno para separação de alíquota de soro e (II) amostra de sangue com as fases de soro e coágulo evidenciadas.

Fonte: (EQUIPE DE CAMPO, 2013)

\subsection{DETECÇÃO DE ANTICORPOS POR ELISA}

Todo procedimento que envolveu o diagnóstico por ELISA, foi realizado em parceria no Laboratório CIRAD UMR15/UMR CIRAD-INRA 1309 "contrôle des maladies animales exotiques et émergentes", sob a responsabilidade do $\mathrm{PhD}$ Thierry Lefrançois, em Guadeloupe, Território Ultramarino Francês (Fig. 61).

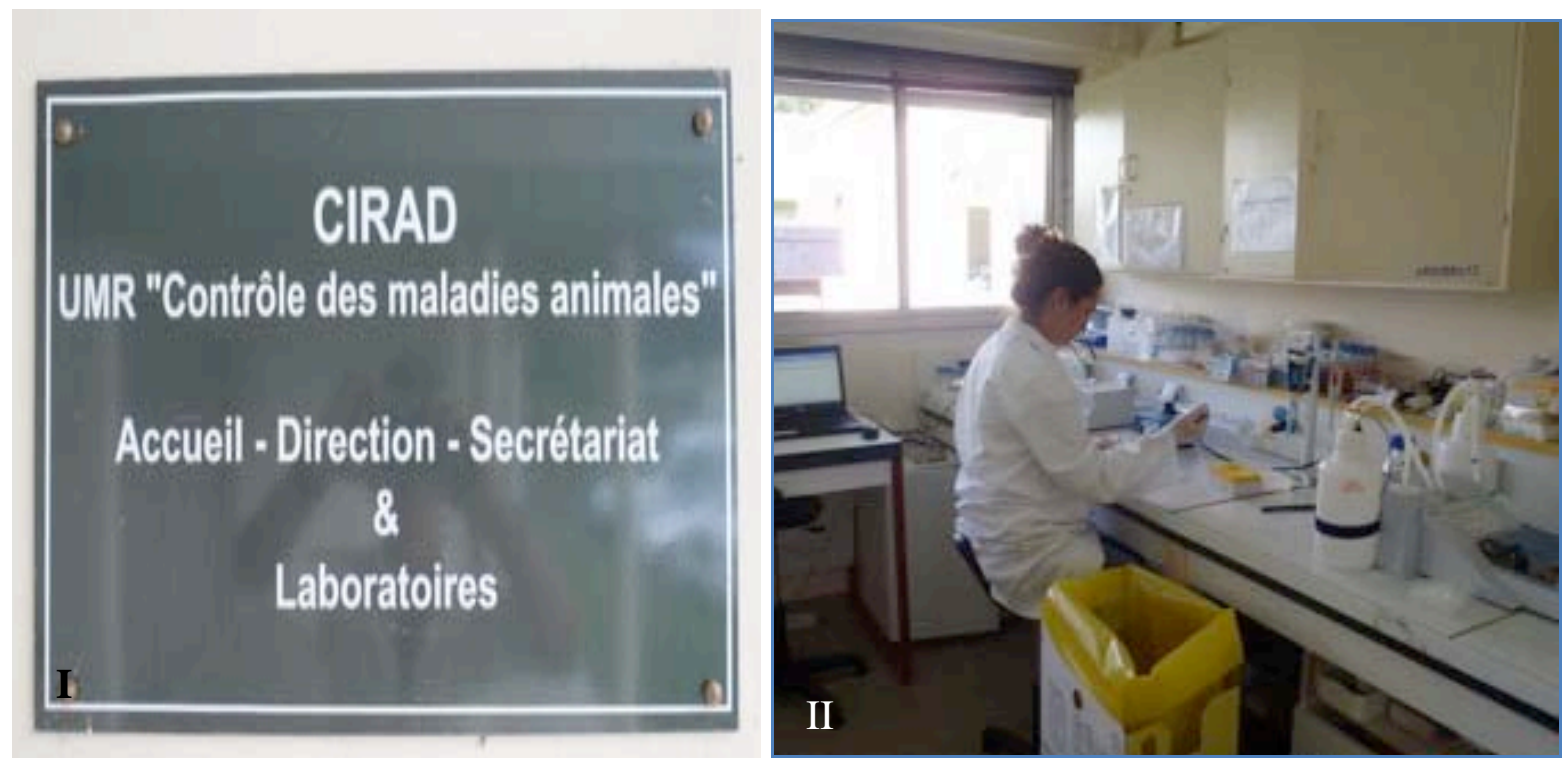



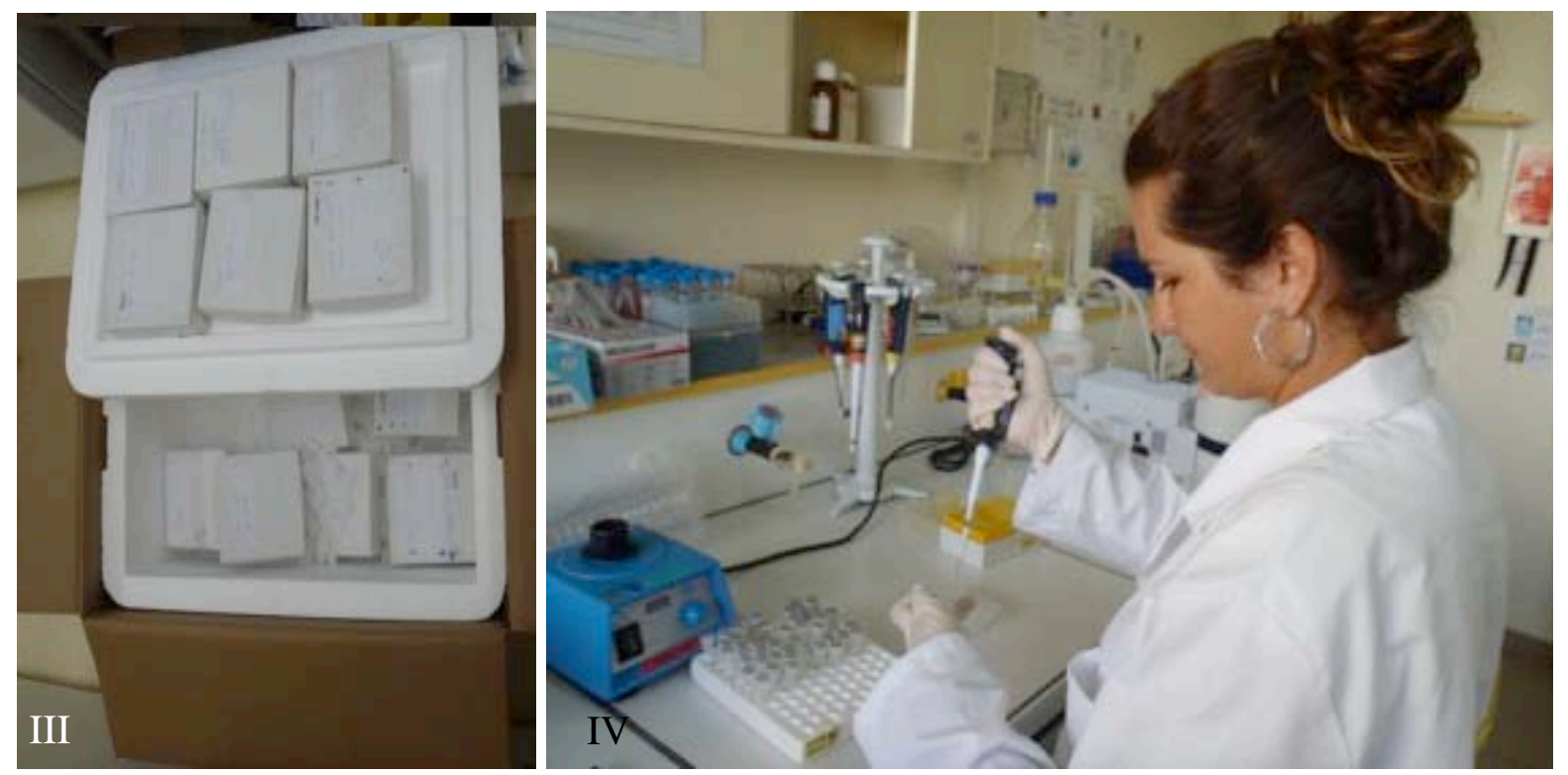

Figura 61 - (I) Placa de identificação do Laboratório do CIRAD, (II) laboratório de sorologia, (III) amostras recebidas em Guadeloupe e (IV) procedimento.

Fonte: Arquivo pessoal

\subsubsection{Procedimento}

A técnica de ELISA (Enzyme Linked Immuno Sorbent Assay) foi realizada e padronizada para detectar a inibição de anticorpos anti-WN no soro de aves e equídeos.

Antes do início do teste, a placa foi preparada para a reação, com a solução de antígeno WN (extraído de células de macacos infectados) em 1/4000, para uma placa, 6,4 mL de tampão coating (revestimento) pH 9,6 (em 1 litro de água MiliQ autoclavada, $50 \mathrm{mM}$ $\mathrm{NaHCO}_{3}$ bicarbonate $=4,2 \mathrm{~g}+50 \mathrm{mM} \mathrm{Na} \mathrm{CO}_{3}$ carbonate $=5,3 \mathrm{~g}$ ) e adicionou- se $1,6 \mu \mathrm{L}$ de antígeno WN. Em todos os procedimentos, sempre foi deixada isolada uma fileira externa de poços na placa sem utilização, evitando efeitos das diferenças de temperatura (Figura 62).

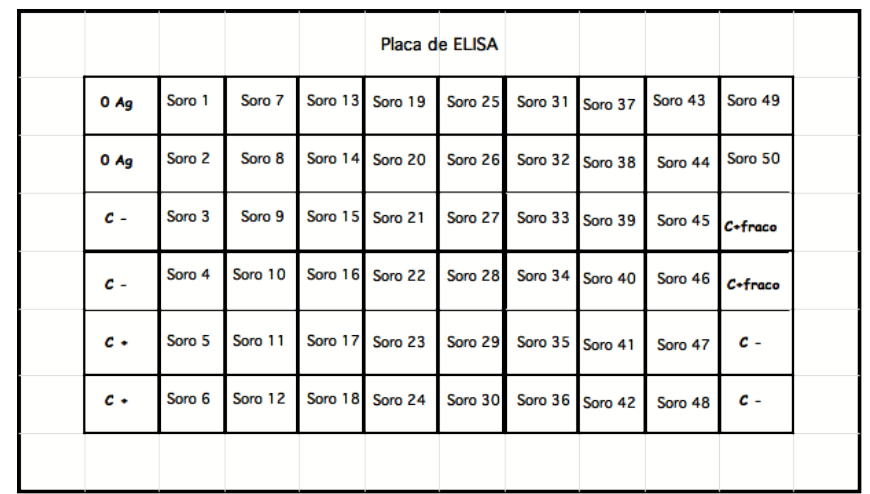

Figura 62 - Esquema de distribuição das amostras em placa. 
Foi distribuído $100 \mu \mathrm{L}$ por poço da solução de antígeno na placa Nunc MaxiSorp ${ }^{\circledR}$ flat-bottom 96 well plate (eBioscience, San Diego, CA, USA). Em seguida, distribuiu-se 100 $\mu \mathrm{L}$ de tampão coating nos dois primeiros poços sem antígeno (branco). A placa foi submetida a incubação overnight a $4{ }^{\circ} \mathrm{C}$ (+/- 2). No momento da realização do teste, incubou-se 1 hora (+/- $6 \mathrm{~min})$ a $37{ }^{\circ} \mathrm{C}(+/-2)$, mexendo em $300 \mathrm{rpm}$ em incubadora.

Após o procedimento de incubação, lavou-se a placa 4 vezes com solução de lavagem PBS $1 X$ tween 20 0,1\% (100 mL de PBS 10X + $900 \mathrm{ml}$ de água MiliQ autoclavada $+1 \mathrm{~mL}$ de Tween 20) com $200 \mu \mathrm{L}$ por poço, usando a máquina para lavagem automática WellWash ${ }^{\mathrm{TM}}$ 4 MK2 (Thermo Scientific, Waltham, MA, USA), com mapa pré-programado. A solução de lavagem foi removida por inversão em papel absorvente. Em seguida, foi distribuído $200 \mu \mathrm{L}$ de tampão de bloqueio (50 mL de tampão de lavagem + 0,1 g BSA), incubou- se $37{ }^{\circ} \mathrm{C}(+/-2)$, $45 \mathrm{~min}$ (+/- 4,5 min), sob leve agitação de $300 \mathrm{rpm}$ em incubadora. O tampão de bloqueio foi preparado no dia do experimento.
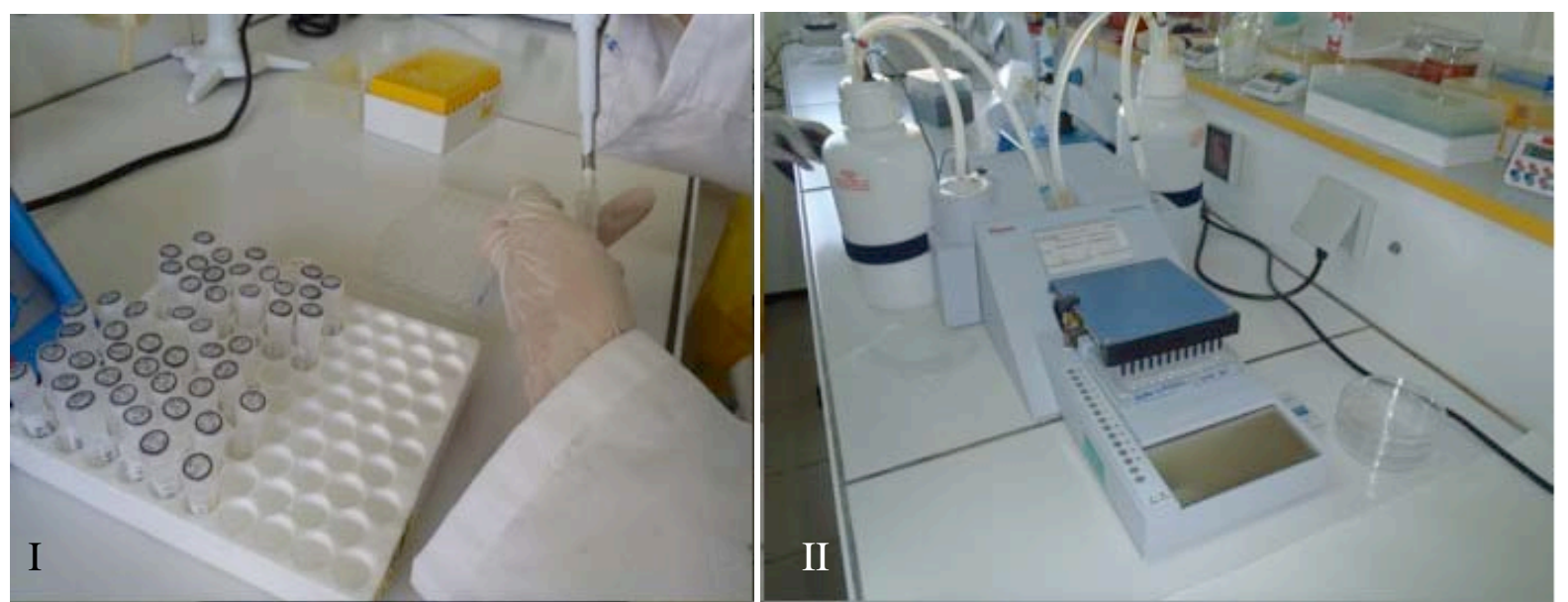

Figura 63 - (I) Distribuição das amostras e (II) lavagem da placa em lavadora automática.

Fonte: Arquivo pessoal

Lavou-se uma vez com a solução de lavagem, conforme descrito anteriormente. Distribuiu-se $45 \mu \mathrm{L}$ de tampão de bloqueio por poço, acrescido de $5 \mu \mathrm{L}$ de amostra. Nos dois poços sem antígeno, foi colocado $50 \mu \mathrm{L}$ de tampão de bloqueio. Incubou-se a $37{ }^{\circ} \mathrm{C}(+/-2), 2$ h (+/- 7,5 min), sob leve agitação de 300 rpm em incubadora.

Para verificar a sensibilidade do teste e validar a placa em uso, utilizamos controle positivo considerado forte (pool de amostras positivas do banco amostral), controle positivo considerado fraco (pool das mesmas amostras positivas do banco amostral, diluídas (1/8) e controle negativo (pool de amostras negativas do banco amostral). 
O controle positivo fraco sempre foi adicionado no início da placa e na oitava coluna para verificar a sensibilidade do teste e validar a placa. Soros de outros territórios fora de Guadeloupe, como Martinique e Guiana são inativados a $56{ }^{\circ} \mathrm{C}(+/-4)$ por 30 minutos (+/- 3 min) antes da realização da análise, por este motivo, todos os soros brasileiros foram inativados antes do envio das amostras para Guadeloupe. Soros hemolisados foram centrifugados e apenas o sobrenadante foi utilizado para o teste.

Após a incubação dos soros, virou-se a placa e descartou-se todo o líquido antes de colocá-la na lavadora, para evitar contaminação da máquina. Lavou-se 4 vezes e preparou-se a solução de anticorpo monoclonal (MAB) anti WNV 3.1112G com o tampão de bloqueio. Este Mouse Anti - West Nile / Kunjin virus Monoclonal Antibody (MAB 8152 - Millipore, Billerica, MA, USA) é específico para a proteína não estrutural 1 do West Nile / Kunjin vírus. O Kunjin (KUN) vírus é muito semelhante a algumas linhagens de West Nile Virus e tem sido classificado com um subtipo do WNV.

Dando continuidade à reação, duas soluções diferentes foram preparadas: uma $1 / 64000^{e}(1 \mu \mathrm{L}$ do MAB + $159 \mu \mathrm{L}$ PBS 1X) a partir do MAB 8152 de 12/11/09, e outra de $1 / 4000^{\mathrm{e}}$ (10 $\mu \mathrm{L}$ do MAB diluição $1 / 160^{\text {a }}+3990 \mu \mathrm{L}$ de tampão de bloqueio) a partir de MAB 8152 de 03/04/08. Distribuiu-se $50 \mu \mathrm{L}$ do tampão com anticorpo por poço na placa e incubouse por 1 hora (+/- $6 \mathrm{~min})$ a $37^{\circ} \mathrm{C}(+/-2)$, sob leve agitação de $300 \mathrm{rpm}$ na incubadora e $1 \mathrm{~h}$ (+/- 6 min) a $4{ }^{\circ} \mathrm{C}(+/-2)$. Lavou-se 4 vezes.

Uma solução foi preparada de anticorpo IgG conjugado purificado HRP (Horseradish Peroxidase) Rabbit Anti - Mouse IgG, Serotec STAR 1314/04/2008 (AbD Serotec, Raleigh, $N C, U S A)$ para $1 / 500^{\mathrm{e}}$ em tampão de bloqueio $+10 \%$ de soro filtrado e inativado de cavalo $(6,4 \mu \mathrm{L}$ HRP anti IgG $+2900 \mu \mathrm{L}$ tampão de bloqueio $+320 \mu \mathrm{L}$ soro inativado de cavalo). Distribuiu-se $50 \mu \mathrm{L}$ de anticorpo por poço na placa e foi mantida por 1 hora (+/- $6 \mathrm{~min})$ a 37 ${ }^{\circ} \mathrm{C}$ (+/- 2), com lenta agitação 300 rpm em incubadora.

Novamente lavou-se por 4 vezes. Então, preparou-se o tampão fosfato-citrato 0,05 M, pH 5,0 (para $1 \mathrm{~L}: 257 \mathrm{~mL} \mathrm{Na}_{2} \mathrm{HPO}_{4}$ 0,2 $\mathrm{M}+243 \mathrm{~mL}$ ac. cítrico 0,1 $\mathrm{M}+500 \mathrm{~mL} \mathrm{H} \mathrm{H}_{2} \mathrm{O}$ ) que será utilizado no próximo tampão. Preparou-se a diluição do substrato/cromógeno (Para uma placa: $11,7 \mathrm{ml}$ de tampão fosfato-citrato $0,05 \mathrm{M} \mathrm{pH} 5$ à temperatura ambiente $+1,3 \mathrm{~mL}$ solução de $\mathrm{TMB}$ à $2 \mathrm{mg} / \mathrm{mL}+10 \mu \mathrm{L} \mathrm{H}_{2} \mathrm{O}_{2}$ à $9 \%$ ) com pouca luz ambiente, pois o TMB (Tétramethylbenzidine) é fotossensível. Distribuiu-se $200 \mu \mathrm{L}$ de solução de TMB, e imediatamente foi incubado a 30 minutos (+/- $3 \mathrm{~min})$, a $37{ }^{\circ} \mathrm{C}(+/-2)$, sob agitação lenta e com pouca luz ambiente. 
A reação foi bloqueada distribuindo-se $100 \mu \mathrm{L} \mathrm{H}_{2} \mathrm{SO}_{4} 2 \mathrm{~N}\left(31,1 \mathrm{~mL} \mathrm{H}_{2} \mathrm{SO}_{4}, 36 \mathrm{~N}+\right.$ $\mathrm{H}_{2} \mathrm{O}$ qsp $500 \mathrm{~mL}$ ) por poço. A densidade óptica (DO) foi obtida em $450 \mathrm{~nm}(+/-0.50 \mathrm{~nm}) \mathrm{no}$ leitor de ELISA Multiskan FC (Thermo Scientific).

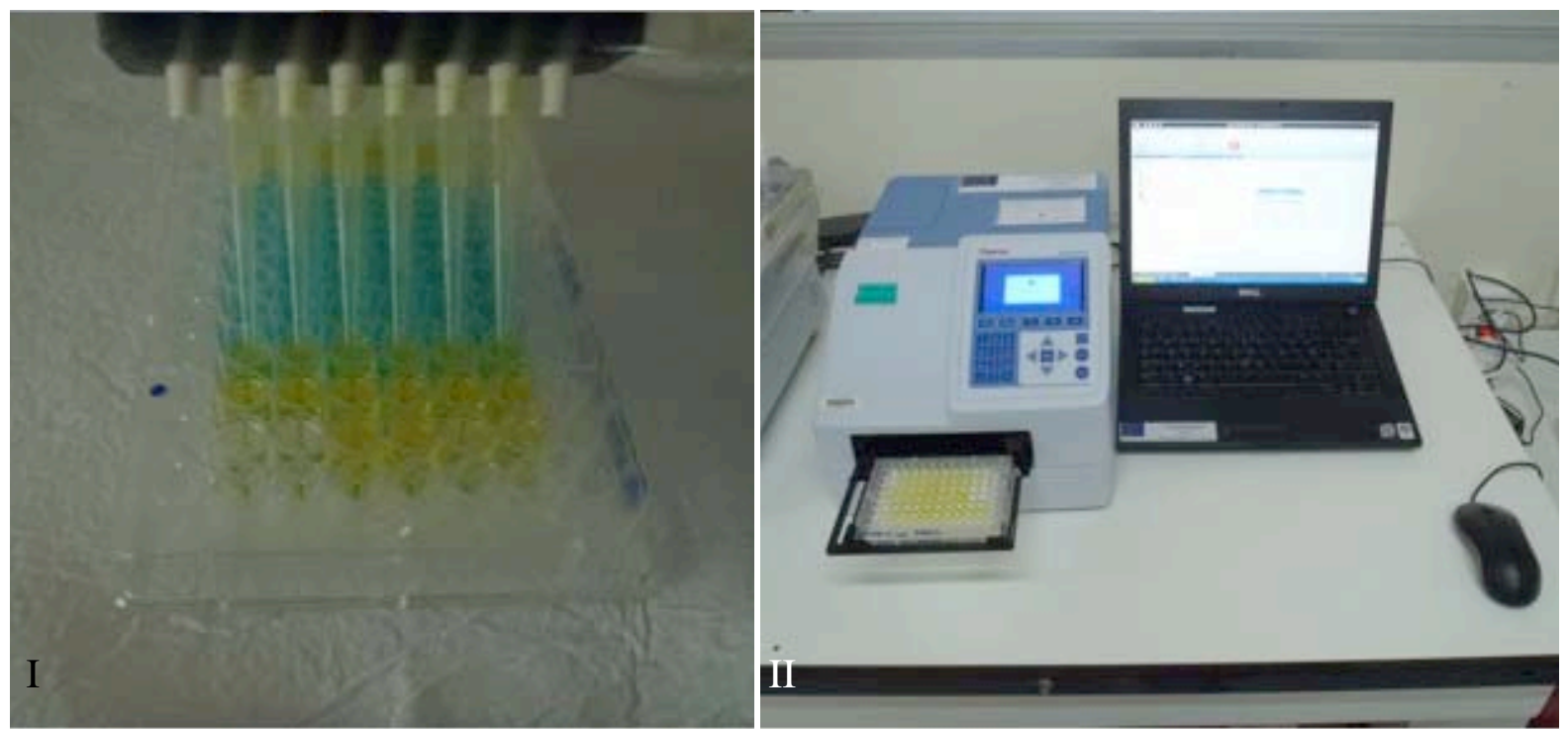

Figura 64 - (I) Bloqueio da reação e (II) leitura da absorbância em leitor de ELISA Fonte: Arquivo pessoal

\subsubsection{Expressão dos resultados}

\subsubsection{Critérios de validação}

A capacidade do soro teste para prevenir a ligação dos anticorpos monoclonais com o antígeno WN é comparada com a de um soro negativo. Os dados estão expressos em \% relativas e um valor de inibição $>30 \%$ em equinos e $>40 \%$ em aves, considerado para indicar a presença de anticorpos WNV. Soro com valores entre 20 e $40 \%$ foram re-testados.

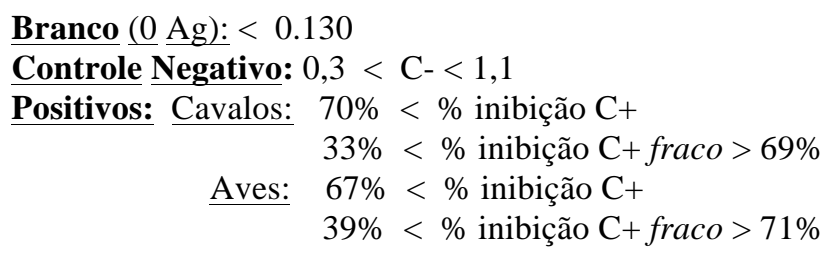

\subsubsection{Cálculo}

\% inibição $\underline{\text { amostra }}=$

100-100 (DO amostra - DO Branco)

DO controle negativo da mesma espécie - DO Branco 


\subsubsection{Auto - Controle}

Os controles positivos considerados pela equipe como sendo fracos e fortes e os controles negativos adicionados a cada placa, devem sempre estar dentro dos intervalos definidos, pois a validação da placa depende destes resultados.

\subsubsection{Soroneutralização em placa}

As amostras que obtiveram resultados positivos no ELISA, foram enviadas ao Laboratório do PhD Robert Lanciotti do Centers for Disease Control and Prevention - CDC, Fort Colins - EUA, para confirmação pelo teste de neutralização por redução em placa.

O teste de neutralização mede todas as imunoglobulinas neutralizantes, como IgM e IgG (KUNO, 2003). Nesta técnica o soro é diluído em várias concentrações e misturado com vírus de titulação conhecida. Caso haja anticorpos neutralizantes, ocorrerá interação entre vírus e anticorpo. O resultado da técnica mostra a inibição da infectividade viral como redução na ligação do vírus à célula e formação de placa por ligação específica dos anticorpos às partículas virais (MAEDA; MAEDA, 2013). Nesta técnica é possível diferenciar anticorpos tipo-específicos para Flavivirus (JOHNSON et al., 2009), porém, em países como o Brasil, onde há grande número de Flavivirus descritos, esta técnica não oferece a capacidade de diferenciar anticorpos específicos para cada Flavivirus, havendo resultados inespecíficos devido à reatividade cruzada. É importante também considerar a existência de Flavivirus ainda não descritos, que podem contribuir para que a reação cruzada ocorra (ORICO, 2013).

\subsection{DETECÇÃO MOLECULAR DO WNV EM AMOSTRAS DE EQUINOS E AVES}

A maior das dificuldades em se trabalhar com o diagnóstico do WNV é a necessidade do uso de uma estrutura laboratorial de biossegurança com nível NB3 (MONINI et al., 2010). Por este motivo, todo o procedimento laboratorial foi realizado dentro do Laboratório Klaus Eberhard Stewien, padrão NB3+ no ICB II - USP (Figura 65 e 66). 


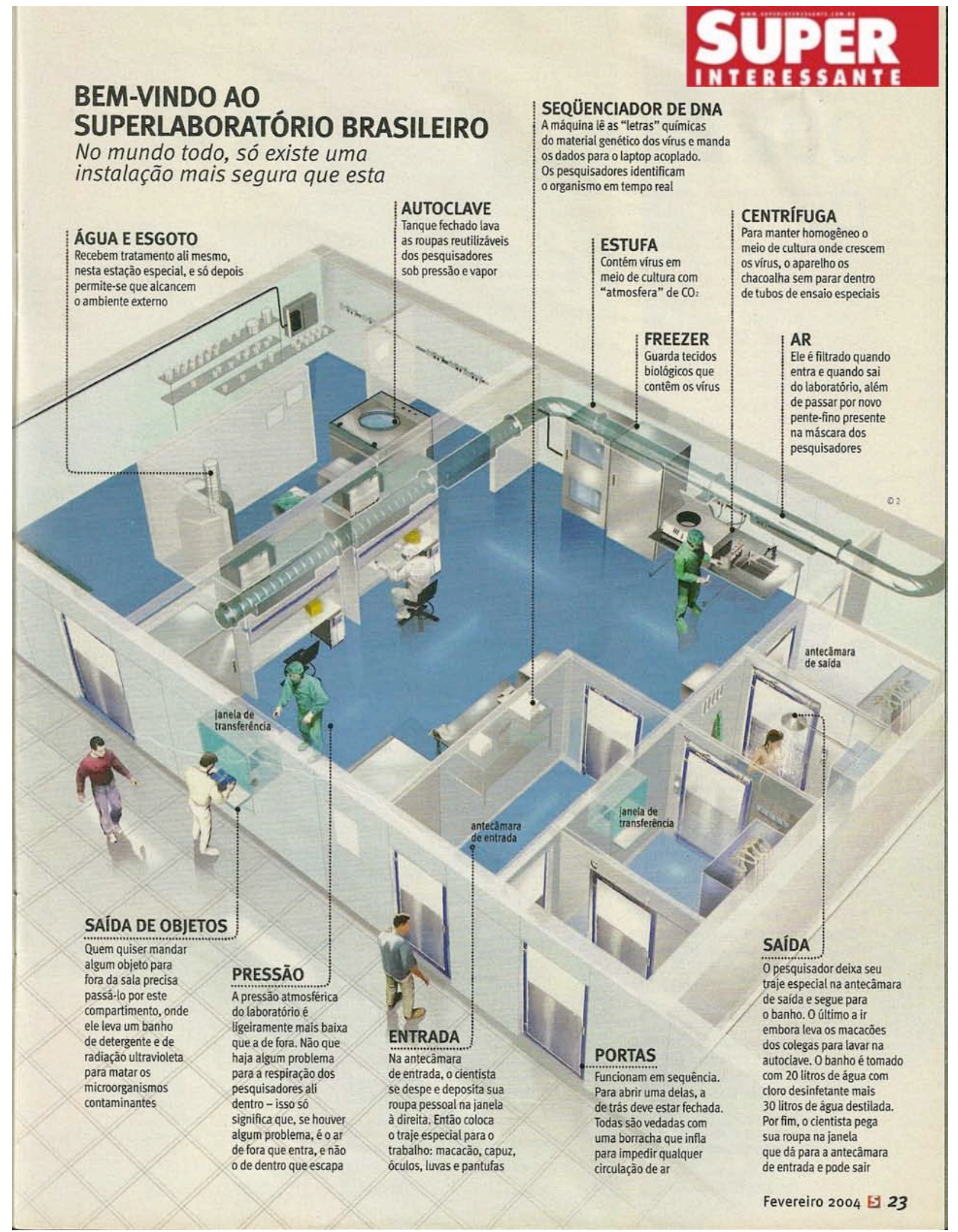

Figura 65 - Desenho esquemático do laboratório Klaus Eberhard Stewien, Biosafety Level 3+ $\left(\mathrm{BSL3}^{+}\right)$

Fonte: (LOPES, 2004) 

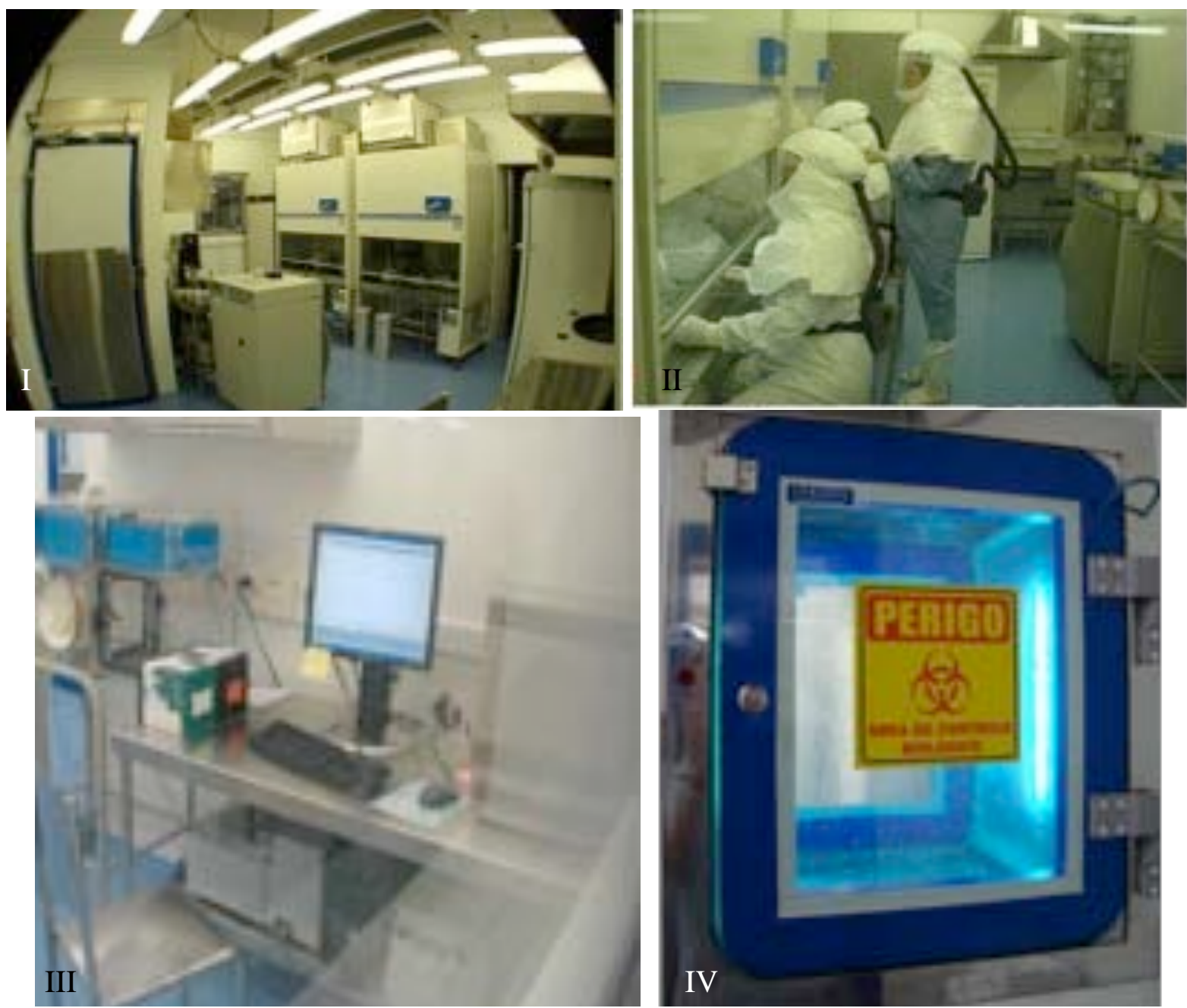

Figura 66 - (I)Visão Panorâmica do laboratório, (II) trabalho com amostras suspeitas, (III) máquina de real-time PCR e (IV) Pass-through para passagem de amostras.

Fonte: (EQUIPE DE CAMPO, 2013)

\subsubsection{Obtenção das sequências}

Inicialmente foi realizado o levantamento bibliográfico e uma análise detalhada de sequências depositadas no GenBank, das regiões que codificam a proteína E do genoma dos Flavivirus, em especial o gene E dos WNV. Através dessa análise, foi possível comparar as diferenças existentes entre as sequências já descritas. Analisamos três regiões normalmente utilizadas para detecção viral (Genes NS1, UTR e E) (ANDERSON et al., 2004). Primers foram construídos para detecção na região do envelope viral.

Foram utilizadas sequências depositadas no banco de dados dos principais WNV isolados, que estão disponíveis no National Center for Biotechnology Information (NCBI), disponível na Internet no endereço http://www.ncbi.nlm.nih.gov/ (WEIDMANN et al., 2003). 


\subsubsection{Alinhamento das Sequências}

O alinhamento foi realizado através do pareamento entre as sequências de nucleotídeos utilizando o programa BioEdit disponível na Internet no endereço http://www.mbio.ncsu.edu/BioEdit/. Foram alinhados os segmentos do gene do envelope (E), NS1 (região não estrutural) e UTR (Não codificadora).

\subsubsection{Seleção de primers}

O protocolo para detecção foi desenvolvido a partir de sequências gênicas depositadas no GenBank com número de acesso: AY660002.1, que refere-se à sequencia do genoma completo de WNV isolado no México em 2003 (BEASLEY et al., 2004), que representava a estirpe viral mais recente disponível no GenBank e de localidade mais próxima ao Brasil, no momento da padronização deste estudo.

A região de interesse onde a sonda foi selecionada trata-se do gene $\mathrm{E}$, local onde se observou uma região conservada interessante para se realizar a detecção. As sequências dos primers e sonda estão representados na tabela abaixo.

Tabela 5 - Descrição de primers e sonda utilizados na reação de one-step real-time RT-PCR.

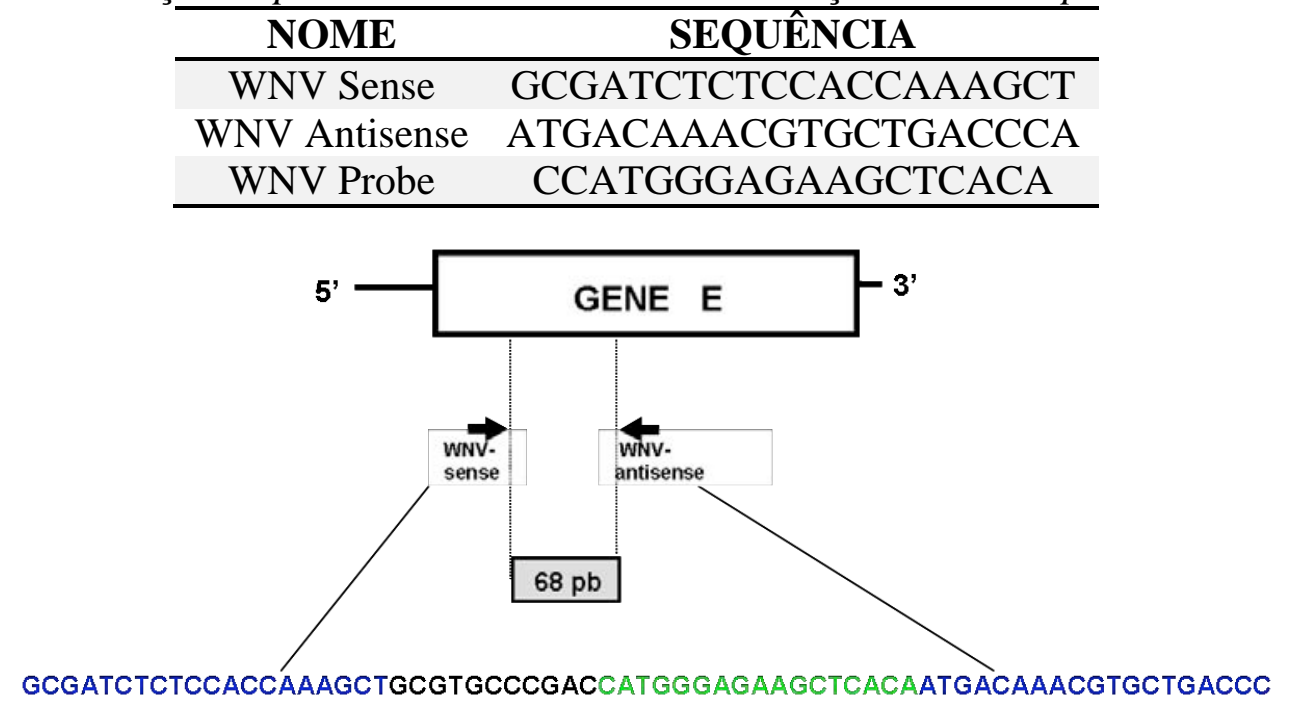

Figura 67 - Sequencia nucleotídica do genoma do WNV representando a localização dos primers (azul) e sonda (verde). 


\subsubsection{Controles positivos}

As amostras positivas utilizadas para a padronização do teste foram obtidas a partir de material gentilmente fornecido pelo Prof. Dr. José Eduardo Levi do Instituto de Medicina Tropical - SP (IMT-SP), provenientes de amostras de plasma humano inativado do painel sorológico de doadores de sangue, gentilmente fornecidas pela Dra. Susan Stramer do American Red Cross, NY, USA.

Para a padronização da técnica, foram utilizadas 10 amostras de controles positivos, com diferentes cargas virais, conforme descrito a seguir.

Tabela 6 - Controles positivos utilizados com as respectivas cargas virais.

\begin{tabular}{cc}
\hline AMOSTRA & CARGA VIRAL \\
\hline Soro 1 & 360.000 \\
Soro 2 & 280.000 \\
Soro 3 & 260.000 \\
Soro 4 & 200.000 \\
Soro 5 & 160.000 \\
Soro 6 & $<5$ \\
Soro 7 & $<100$ \\
Soro 8 & 100 \\
Soro 9 & 500 \\
Soro 10 & 30.000 \\
\hline
\end{tabular}

Podemos comparar, dentro de uma curva de detecção de fluorescência por diferentes cargas virais, qual a aproximada carga viral da amostra biológica testada, quando comparada à curva das amostras positivas.

\subsubsection{Controle interno da reação}

Por se tratar de material biológico de animais, incluindo swabs oro/traqueal e cloacal/anal, utilizamos como controle endógeno da reação em amostras aleatórias, um par de primers para o RNA ribossômico mitocondrial 16S (DESJARDINS; MORAIS, 1990; SPICER; DUNIPACE, 2004), testados por RT-PCR para avaliar a eficácia da reação excluindo a possibilidade da ação de inibidores. 
Tabela 7 - Descrição dos primers de 16S utilizados na reação.

\begin{tabular}{ccccc}
\hline Gênero & Primer & Sequência & Referência & Amplicon (pb) \\
\hline \multirow{2}{*}{ rRNA } & $16 \mathrm{Sa}$ & ATGTTTTTGGTAACAGTCG & (SPICER; & \\
$16 \mathrm{~S}$ & & & DUNIPACE, & $609 \mathrm{pb}$ \\
& $16 \mathrm{Sbr}$ & CCGGTCTGAACTCAGATCACGT & 2004) & \\
\hline
\end{tabular}

\subsubsection{Extração do material genético}

Nos primeiros anos do projeto o método de extração de RNA viral utilizado foi partindo de $140 \mu \mathrm{L}$ do material de swab traqueal e cloacal, utilizando o QIAamp viral RNA Mini Spin Colunn kit (Qiagem, Gerantown, MD, USA), seguindo as recomendações do fabricante. Porém, durante o decorrer do projeto, esteve à disposição o equipamento MagMax ${ }^{T M}$ Express 96 Viral RNA Isolation Kit AM1836 (Life Technologies, Carlsbad, CA, USA), utilizado também para extração do material genético, nos permitindo um melhor fluxo de trabalho tanto pela agilidade da realização de uma placa com 96 amostras por vez, quanto pela minimização da manipulação das mesmas garantindo um menor índice de possíveis contaminações. Para garantir a eficiência do procedimento, testamos alíquotas das mesmas amostras nas duas técnicas e obtivemos o mesmo resultado final na detecção viral dos controles. Os procedimentos de extração no equipamento acima citado seguiram as recomendações do fabricante.

\subsubsection{One-step real-time RT-PCR}

Para detecção das amostras, foram adicionados $12,5 \mu \mathrm{L}$ de 2x RT-PCR Buffer, 1,2 $\mu \mathrm{L}$ de 25x Primer/Probe mix, 1,0 $\mu \mathrm{L}$ de 25x RT-PCR enzimas e 1,67 $\mu \mathrm{L}$ de Detector Enhancer (Life Technologies) e 8,63 $\mu \mathrm{L}$ de RNA extraído, totalizando $25 \mu \mathrm{L}$ de volume final. Para a padronização da detecção dos produtos amplificados utilizamos a ABI 7300 PCR System (Life Technologies). As condições utilizadas foram de uma temperatura inicial de $45{ }^{\circ} \mathrm{C}$ por 10 min Transcrição Reversa (RT) seguida de $95^{\circ} \mathrm{C}$ por 10 min (inativação da enzima RT e ativação da Taq Polimerase), seguindo 40 ciclos de $95{ }^{\circ} \mathrm{C}$ por $15 \mathrm{seg}$ (desnaturação do DNA) e $60{ }^{\circ} \mathrm{C}$ por $45 \mathrm{seg}$ (Amplificação e coleta de dados de fluorescência). Aplicamos o teste em água ultra-pura como controle negativo nas reações. 


\subsection{DETECÇÃO MOLECULAR AUTOMATIZADA DO WNV EM AMOSTRAS DE EQUÍDEOS}

Em setembro de 2011 foi realizado estágio no Centro de Imunologia e Imunoterapia São Paulo (CII), em conjunto com o Me. Marcelo Plaisant Geraldi, supervisionado pelo Prof. Dr. José Eduardo Levi do Laboratório de Virologia do IMT-SP, para o diagnóstico molecular do WNV, através de técnica de real-time RT-PCR automatizado, utilizado em bancos de sangue dos EUA e Canadá.

Em complemento à pesquisa molecular do teste de detecção viral já padronizado em $\mathrm{NB} 3+$, foi realizado o teste molecular com sistema automatizado de PCR em Tempo Real Cobas ${ }^{\circledR}$ TaqScreen West Nile Virus Test (Roche, Pleasanton, CA, EUA), rotineiramente utilizado nos EUA e Canadá para a triagem de doadores de sangue (GERALDI, 2012).

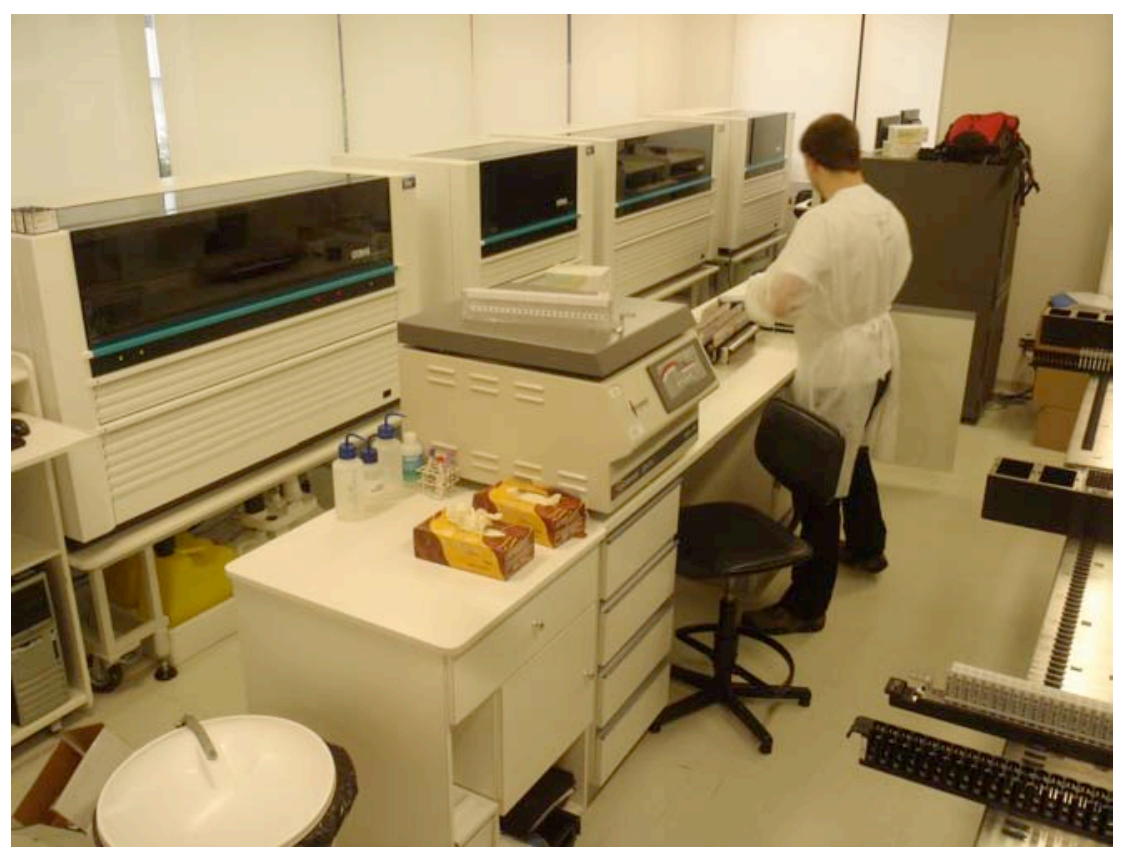

Figura 68 - Sala de biologia molecular do Laboratório CII.

Fonte: Arquivo pessoal

Adotamos esta técnica para avaliação das amostras de soro e macerados de cérebros de equídeos, em adição às amostras já dispostas em banco amostral utilizadas nos testes anteriores. A sensibilidade analítica deste método é reportado como 40 cópias $/ \mathrm{mL}$ para a linhagem WNV 1 (PAI et al., 2008). 


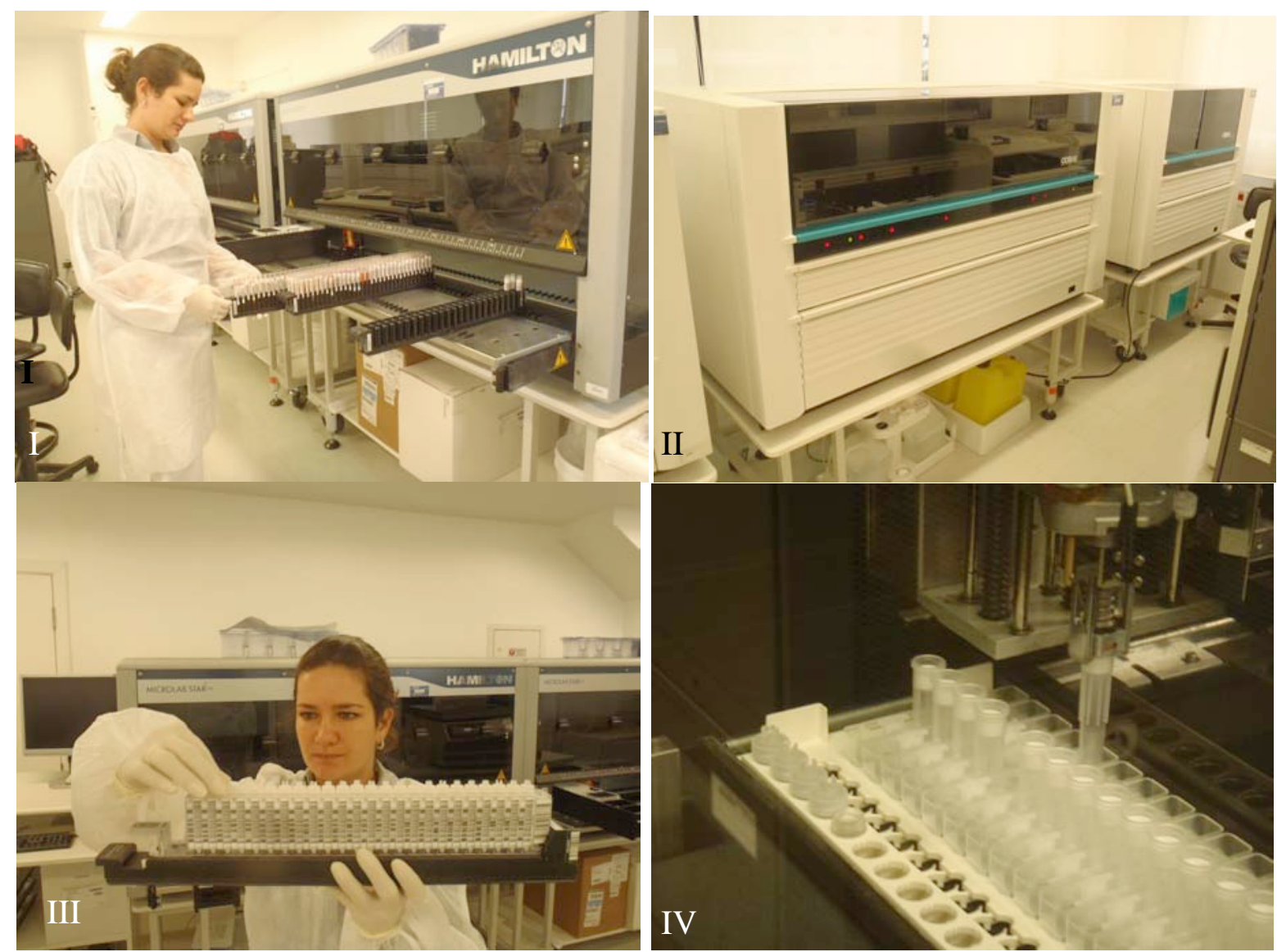

Figura 69 - (I) automação de triagem de amostras, (II) automação para extração e detecção molecular, (III) amostras identificadas com código de barras e (IV) automação em funcionamento.

Fonte: Arquivo pessoal

O Cobas ${ }^{\circledR}$ TaqScreen West Nile Virus Test é um teste qualitativo que permite o rastreio e detecção do RNA do WNV em amostras infectadas, individuais ou em pool. Para amostras de sangue total e componentes sanguíneos, podem ser testadas em pools constituídas por não mais de seis alíquotas iguais de amostras individuais. O teste utiliza uma técnica genérica de preparação dos ácidos nucleicos no equipamento $C O B A S^{\circledR}$ AmpliPrep. O RNA do WNV é então detectado através de amplificação automática por PCR em tempo real no analisador $\operatorname{COBAS}^{\circledR}$ TaqMan $^{\circledR}$. O teste incorpora um controle interno para monitoramento do seu desempenho individual, assim como a enzima AmpErase para reduzir a contaminação potencial por material previamente amplificado (amplicon).

$\mathrm{O}$ procedimento baseia-se em 4 processos principais: pooling de amostras e pipetagem de controles automáticas utilizando o pipetador Hamilton MICROLAB ${ }^{\circledR}$ STAR/STARlet IVD; preparação automática de amostras utilizando o equipamento COBAS ${ }^{\circledR}$ AmpliPrep; amplificação automática de ácidos nucleicos e detecção automática em tempo real de produtos da PCR utilizando o analisador $\operatorname{COBAS}{ }^{\circledR} \operatorname{TaqMan}^{\circledR}$ e gestão automática de dados 
utilizando o software de Pooling e Gestão de Dados (PDM). Todos os procedimentos foram realizados conforme instruções do fabricante.

Dentre as 994 amostras de soros de equídeos do estado do Mato Grosso, apenas 416 foram analisadas por este método, tendo em vista o volume mínimo amostral de 1,5 mL. As localidades são Nova Brasilândia, Planalto da Serra, Arenápolis, Santo Antônio Leverger, Nova Bandeirantes, Jangada, Nova Mutum, Diamantino, Lucas do Rio Verde, Campo Verde e Poconé. Os animais eram de propriedade privada, utilizados principalmente para transporte e movimentação do gado. Os soros foram coletados de equídeos assintomáticos no momento da amostragem, que não foram vacinados contra o WNV e sem história de movimento fora da área de coleta. Também foram testadas por este método as 63 amostras de cérebros de equídeos provenientes do banco amostral do IB e as 6 amostras positivas para o ELISA, provenientes do MT.

\subsection{DETECÇÃO MOLECULAR DO WNV EM CAMPO}

Visando a agilidade na detecção do vírus e a possível entrada do WNV no país em locais remotos, com ausência de atividade humana e existência apenas de vida silvestre, padronizamos a detecção molecular do RNA viral em campo.

Na expedição de 2011 ao Parque Nacional da Lagoa do Peixe - RS, padronizamos o teste molecular one-step real-time RT-PCR em campo. As amostras de swab traqueal e cloacal foram colhidas e em seguida realizamos a extração do material genético com o QIAamp Viral RNA Mini Kit (Qiagen) conforme indicações do fabricante. A realização de tal procedimento só é possível em campo por conta do armazenamento dos reagentes utilizados, que deve ser à temperatura ambiente e cujo principal equipamento é a centrífuga, que pode ser tranquilamente utilizada, ligada ao gerador.

O teste molecular foi realizado em campo com o equipamento Smart Cycle II (Cepheid, Sunnyvale, CA, USA), usando o AgPath-ID ${ }^{\mathrm{TM}}$ One-Step RT-PCR kit (Life Technologies), conforme instruções do fabricante e já tendo sido utilizado em campo em outro estudo (ARAUJO et al., 2011). Utilizando-se dry shippers para armazenar e transportar os reagentes para a detecção molecular, que necessitam de refrigeração, e com auxilio do gerador para o funcionamento do equipamento, foi possível realizar o desafio da extração genética e detecção viral em campo com absoluto sucesso. 

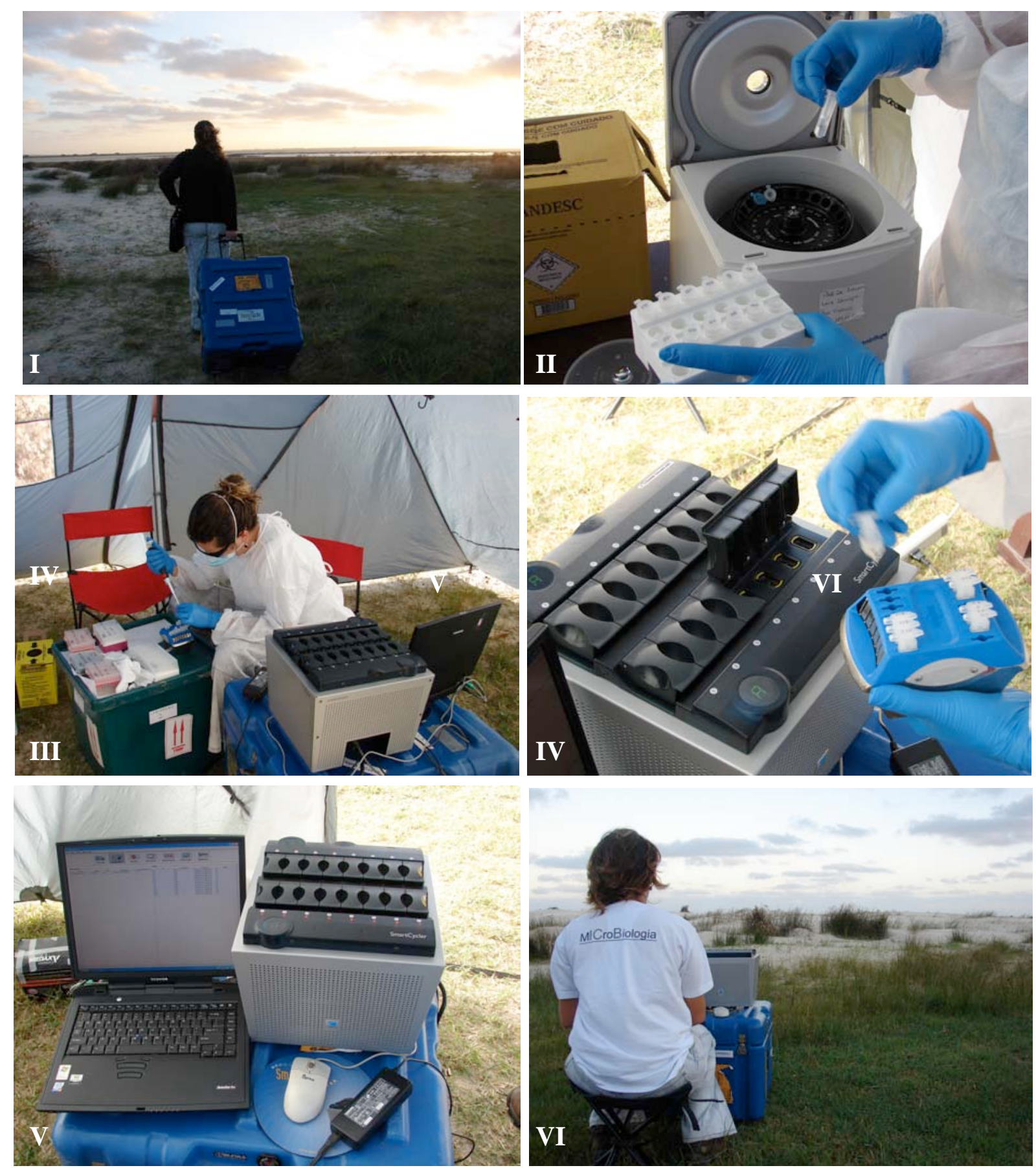

Figura 70 - (I) Transporte da máquina de real-time, (II) procedimento de extração do material genético, (III) preparação de reagentes para o teste molecular, (IV) equipamento de real-time RT-PCR, (V) reação em andamento e (VI) uso dos equipamentos em campo.

Fonte: (EQUIPE DE CAMPO, 2013)

Na última expedição científica realizada, no Pantanal mato-grossense em 2012, realizamos novamente os testes de extração de material genético e teste de detecção molecular em 26 amostras entre aves e equinos. 


\subsection{CULTURA CELULAR}

Com base no achado de uma amostra suspeita para a presença do WNV pelo diagnóstico molecular em campo, na expedição do Pantanal em 2012, demos sequência à confirmação através do isolamento em cultura de células. Para isto, foi encaminhada uma alíquota da amostra à Me. Telma Alves Monezi do Laboratório de Virologia da Profa. Dra. Dolores Ursula Mehnert do Instituto de Ciências Biomédicas II - USP, para que fosse cultivada em células.

\subsubsection{Sistema celular utilizado}

Células de linhagem estabelecida de rim de macaco (VERO) foram cultivadas visando o isolamento viral das amostras clínicas, como já citado em trabalho anterior (CHU; NG, 2003)

Figura 71 - Tapete celular do controle negativo de células VERO.

Fonte: Arquivo pessoal

\subsubsection{Método de cultivo}

As células foram mantidas em garrafas com meio Eagle MME (meio mínimo essencial), acrescido de $5 \%$ de soro fetal bovino (SFB) (Cultilab; Campinas - Brasil) e antibióticos (Penicilina $100 \mathrm{U} / \mathrm{ml}$ e Estreptomicina $0,1 \mathrm{mg} / \mathrm{ml}$ ).

O cultivo das células foi realizado em intervalos de 5 a 7 dias. Para o repique, o meio de crescimento da cultura foi decantado e a seguir, a monocamada celular foi lavada por 2 a 3 vezes consecutivas, com $10 \mathrm{ml}$ de solução de tripsina 1:250 (BD, Franklin Lakes, NJ, USA) a 0,25\% em associação com EDTA 0,02\% pH 8,0. Quando as células se apresentavam 
desprendidas, foram ressuspendidas em $3 \mathrm{ml}$ de meio de crescimento, igual ao meio de manutenção, porém com $10 \%$ de soro fetal bovino. A seguir, esta suspensão de células foi ressuspendida em $60 \mathrm{ml}$ de meio Eagle com 10\% de SFB e distribuída em novas garrafas e tubos de cultura. As culturas foram mantidas em posição estacionária em estufa a $37^{\circ} \mathrm{C}$.

\subsubsection{Inoculação}

A metodologia utilizada para o isolamento da amostra suspeita foi preconizada segundo protocolo de rotina do laboratório (MONEZI, 2000). Alíquotas de 0,1 ml, 0,2 $\mathrm{ml}$ e 0,3 $\mathrm{ml}$ da amostra suspeita, foram inoculadas a cada um dos três tubos contendo células VERO, previamente cultivadas conforme descrito anteriormente. Após a adição de meio Eagle contendo $2 \%$ de SFB para um volume final de $1,0 \mathrm{ml}$, as culturas foram mantidas a $37{ }^{\circ} \mathrm{C}$ e observadas diariamente ao microscópio por um período de até 15 dias. Visando o isolamento viral, três cultivos sucessivos foram realizados.

\subsection{ANÁLISE DAS AMOSTRAS SUSPEITAS POR BIOLOGIA MOLECULAR E SEQUENCIAMENTO}

Para as amostras que apresentaram resultados positivos pelos métodos moleculares, procedemos da seguinte forma:

\subsubsection{Transcrição Reversa- $R T$}

A reação foi realizada utilizando o SuperScript ${ }^{\circledR}$ II Reverse Transcriptase $(R T)$ kit (Life Technologies) a partir de $16 \mu \mathrm{l}$ de RNA extraído, adicionando $8,0 \mu \mathrm{L}$ de $\mathrm{MgCL}_{2}(25$ $\mathrm{mM}), 4,0 \mu \mathrm{L}$ de First-Strand Buffer (250 mM Tris-HCl, pH 8.3), 4,0 $\mu \mathrm{L}$ de DTT (0.1 M), 2,0 $\mu \mathrm{L}$ de enzima Transcriptase Reversa (SuperScript ${ }^{\mathrm{TM}}$ II RT $200 \mathrm{u} / \mu \mathrm{L}$ ), 2,0 $\mu \mathrm{L}$ de random primers $(10 \mathrm{mM}), 2,0 \mu \mathrm{L}$ de dNTP mix $(250 \mathrm{mM}), 2,0 \mu \mathrm{L}$ de RNaseOUT ${ }^{\mathrm{TM}}(40 \mathrm{u} / \mu \mathrm{L})$ totalizando $40 \mu \mathrm{L}$. A mistura foi submetida a uma temperatura de $25^{\circ} \mathrm{C}$ por $10 \mathrm{~min}$, seguidos de $50{ }^{\circ} \mathrm{C}$ por $50 \mathrm{~min}, 85^{\circ} \mathrm{C}$ por 5 min e por final $4{ }^{\circ} \mathrm{C}$ por tempo indeterminado. 


\subsubsection{Real- time PCR (Sistema SYBR Green)}

O sistema SYBR Green, consiste em uma molécula fluorescente que intercala a dupla fita-DNA, incluindo ligações inespecíficas e primer-dimers, levando à reação a uma baixa especificidade (ESPY et al., 2006), porém, com alta sensibilidade (ZIPPER et al., 2004), que é comumente utilizado na detecção de amplicons com tamanhos de aproximadamente $250 \mathrm{pb}$ (pares de bases). No trabalho, primers foram utilizados para gerar um amplicon de $270 \mathrm{pb}$ na detecção viral (MOUREAU et al., 2007). As reações foram realizadas com volume final de 25 $\mu \mathrm{L}$ contendo 12,5 $\mu \mathrm{L}$ do $S Y B R^{\circledR}$ Green PCR Master Mix $2 X$ (incluindo Taq DNA polymerase, reaction buffer, dNTP mix e SYBR dye (Life Technologies), $1 \mu \mathrm{L}$ de cada primer ( 5 p/Mol), 5 $\mu \mathrm{L}$ do cDNA e 5,5 $\mu \mathrm{L}$ água UltraPure. Utilizamos as condições de termociclagem, sendo 94 ${ }^{\circ} \mathrm{C}$ por 5 min (inativação da UNG e ativação da AmpliTaq Gold DNA Polimerase) seguidos de 40 ciclos de $94{ }^{\circ} \mathrm{C}$ por 30 segundos, $52{ }^{\circ} \mathrm{C}$ por 30 segundos e $72{ }^{\circ} \mathrm{C}$ por 45 segundos. O anelamento dos oligonucleotídeos iniciadores ocorre durante a rampa de descida de $94{ }^{\circ} \mathrm{C}$ a 52 ${ }^{\circ} \mathrm{C}$ e a coleta do sinal ocorre nos 30 segundos finais da etapa de extensão.

\subsubsection{Curva de Dissociação}

Para identificação dos produtos de PCR gerados na presença do SYBR Green, após a amplificação e a possível formação de dímeros inespecíficos (KUBISTA et al., 2006), realizamos uma "Curva de Dissociação", que consiste na análise da Temperatura de melting (Tm) pelo incremento da temperatura de $60{ }^{\circ} \mathrm{C}$ até $95{ }^{\circ} \mathrm{C}$ com taxa de transição linear de 0.1 ${ }^{\circ} \mathrm{C} / \mathrm{seg}$, ao final da amplificação. A fluorescência das amostras foi monitorada continuamente enquanto a temperatura aumentava gradativamente e a fluorescência diminuía, respectivamente. Como o SYBR Green é liberado durante a desnaturação, resultando num decréscimo do sinal de fluorescência, o software calcula a Tm, ou seja, a taxa de mudança da fluorescência, sendo apresentada como uma função da temperatura (ARAUJO, 2011). A carga viral é subentendida de acordo com o cycle threshold $(\mathrm{Ct})$, que entende-se pelo momento em que a fluorescência emitida ultrapassa o limiar estabelecido, visto que quanto menor o valor do $\mathrm{Ct}$, maior a quantidade de produtos amplificados, ou seja, o valor do Ct é inversamente proporcional à quantidade de produto da reação (SCHMITTGEN; LIVAK, 2008). 


\subsubsection{PCR convencional}

Com o objetivo de obter sequências das amostras suspeitas, realizamos também a amplificação das mesmas amostras utilizando o mesmo par de primers testados pelo método SYBR Green (MOUREAU et al., 2007), como também pelos primers genéricos para detecção de Flavivirus (HENRIQUES, 2008) e por fim utilizamos os primers do sistema TaqMan onestep real-time RT-PCR (OMETTO et al., 2013).

\subsubsection{PCR com primers MOUREAU et al., 2007 - modificado}

Para a reação de PCR com os mesmos primers (Tabela 8) do método SYBR Green, foram utilizados 2,5 $\mu \mathrm{L}$ de PCR Buffer (10X), 1,0 $\mu \mathrm{L}$ de dNTPs (10 mM), 1,0 $\mu \mathrm{L}$ de cada primer (10 pmol) FWD (sense) e RVS (antisense), $1 \mu \mathrm{L}$ de $\mathrm{MgCL}_{2}(50 \mathrm{mM}), 0,3 \mu \mathrm{L}$ de Platinum ${ }^{\circledR}$ Taq DNA Polymerase $5 \mathrm{U} / \mu \mathrm{L}$ (Life Technologies), 2,5 $\mu \mathrm{L}$ de cDNA e 15,7 $\mu \mathrm{L}$ de água MiliQ, totalizando um volume final de $25 \mu \mathrm{L}$. A amplificação foi realizada em termociclador 9700 (Perkin Elmer - Life Technologies). As amostras foram submetidas a 95 ${ }^{\circ} \mathrm{C}$ por 10 minutos, seguidos por 40 ciclos de amplificação, sendo cada ciclo composto de 3 temperaturas: desnaturação das amostras a $94{ }^{\circ} \mathrm{C}$ (30 segundos), pareamento dos primers a 50 ${ }^{\circ} \mathrm{C}$ (30 segundos) e extensão das fitas de DNA a $72{ }^{\circ} \mathrm{C}$ (45 segundos). Depois do término dos ciclos, um período de 10 minutos a $72{ }^{\circ} \mathrm{C}$ foi aplicado para a finalização das extensões ocorridas e por final a reação permaneceu a $4{ }^{\circ} \mathrm{C}$ por tempo indeterminado.

Tabela 8 - Descrição dos primers utilizados na reação.

\begin{tabular}{ccccc}
\hline Gênero & Primer & Sequência & Referência & Amplicon (pb) \\
\hline \multirow{2}{*}{ Flavivirus } & FWD & TGYRBTTAYAACATGATGGG & $\begin{array}{c}\text { (MOUREAU } \\
\text { et al., 2007) } \\
\text { modificado }\end{array}$ & 270 \\
& RVS & GTGTCCCAICCNGCNGTRTC & . & \\
\hline
\end{tabular}

4.9.4.2 PCR com primers FULOP et al., 1993

Para a reação de PCR com os primers genéricos (Tabela 9) para Flavivirus (FULOP et al., 1993), foram utilizados 2,5 $\mu \mathrm{L}$ de PCR Buffer (10X), 1,0 $\mu \mathrm{L}$ de dNTPs (10 mM), 1,0 $\mu \mathrm{L}$ de cada primer (10 pmol) SFG1 (sense) e CFG2 (antisense), $1 \mu \mathrm{L}$ de $\mathrm{MgCL}_{2}(50 \mathrm{mM}), 1,0 \mu \mathrm{L}$ de Platinum ${ }^{\circledR}$ Taq DNA Polymerase $5 \mathrm{U} / \mu \mathrm{L}$ (Life Technologies), 5,0 $\mu \mathrm{L}$ de cDNA e 12,5 $\mu \mathrm{L}$ 
de água MiliQ, totalizando um volume final de $25 \mu \mathrm{L}$. A amplificação foi realizada em termociclador 9700 (Perkin Elmer - Life Technologies). As amostras foram submetidas a 94 ${ }^{\circ} \mathrm{C}$ por 5 minutos, seguidos por 45 ciclos de amplificação, sendo cada ciclo composto de 3 temperaturas: desnaturação das amostras a $94^{\circ} \mathrm{C}(30$ segundos), pareamento dos primers a 58 ${ }^{\circ} \mathrm{C}$ (30 segundos) e extensão das fitas de DNA a $72{ }^{\circ} \mathrm{C}$ (1 minuto). Depois do término dos ciclos, um período de 10 minutos a $72{ }^{\circ} \mathrm{C}$ foi aplicado para a finalização das extensões ocorridas e por final a reação permaneceu a $4{ }^{\circ} \mathrm{C}$ por tempo indeterminado.

Tabela 9 - Descrição do par de primers utilizado na reação.

\begin{tabular}{ccccc}
\hline Gênero & Primer & Sequência & Referência & Amplicon (pb) \\
\hline \multirow{2}{*}{ Flavivirus } & sense FG & GGTCTCCTCTAACCTCTAG & & \\
& & & (FULOP et & 1000 \\
& cFG $_{2}$ & GAGTGGATGACCACGGAAGA & al., 1993) & \\
& & CATGC & & \\
\hline
\end{tabular}

4.9.4.3 PCR com primers OMETTO et al., 2013

Para a reação de PCR convencional com os primers específicos para WNV (Tabela 10), conforme protocolo de detecção, realizamos dois protocolos, sendo o primeiro exatamente nas mesmas condições do método de detecção usado no one-step real-time RTPCR, com a exceção do uso da sonda e o outro realizado a partir de 5,0 $\mu \mathrm{L}$ do cDNA randômico já descrito acima.

Amostra de vírus da Dengue, da Febre amarela e do WNV foram utilizadas como controle positivo das reações.

Tabela 10 - Descrição dos primers utilizados na reação.

\begin{tabular}{ccccc}
\hline Vírus & Primer & Sequência & Referência & Amplicon (pb) \\
\hline $\begin{array}{c}\text { West Nile } \\
\text { virus }\end{array}$ & SEQ1F & GCGATCTCTCCACCAAAGCT & (OMETTO & 68 \\
& SEQ1R & TGGGTCAGCACGTTTGTCAT & et al., 2013) & 68
\end{tabular}

\subsubsection{Visualização em gel de agarose}

Após a amplificação e análise dos dados, para confirmação dos resultados, as amostras foram aplicadas em gel de agarose 2,5\% corado com brometo de etídio e visualizadas em luz 
ultravioleta. O tamanho dos fragmentos amplificados foi determinado com auxílio de um marcador (peso) de $1.000 \mathrm{~Kb}$, DNA Ladder (Thermo Scientific - Fermentas). Os fragmentos amplificados geraram a vizualização de bandas de aproximadamente 270 pb (primer Moureau modificado), 68 pb (primer específico WNV) e 1.000 pb (primer genérico para Flavivirus).

\subsubsection{Purificação do produto de PCR}

Para a purificação dos produtos da PCR utilizou-se o ExoSAP-IT® PCR Product Cleanup Kit (GE Lifesciences). Após o término da reação de PCR a maior parte dos primers e dNTP permanece intacta, e, se não retiradas, as impurezas irão interferir na reação de sequenciamento. As enzimas Exonuclease I (Exo I) e Shrimp Alkaline Phosphatase (SAP) removem os materiais indesejados. Em seguida a reação de sequenciamento realizou-se normalmente. Para cada reação foi utilizado $10 \mu \mathrm{L}$ de DNA amplificado por PCR, 6,0 $\mu \mathrm{L}$ de ExoSap, e 4,0 $\mu \mathrm{L}$ de água ultra pura totalizando $20 \mu \mathrm{L}$ de volume final de reação. As condições de reação foram de $37{ }^{\circ} \mathrm{C}$ por 15 min (ativação enzimática) e $80{ }^{\circ} \mathrm{C}$ por 15 min (para inativação das enzimas).

\subsubsection{Sequenciamento de DNA}

Os produtos purificados foram sequenciados conforme SAMBROOK; FRITSCH; MANIATIS, 1989 e SANGER; NICKLEN; COULSON, 1977. Para a reação, foi utilizado 2,0 $\mu \mathrm{L}$ de tampão de sequenciamento (Sequence Buffer- 5X), 2,0 $\mu \mathrm{L}$ de reagente de sequenciamento BigDye Terminator Cycle Sequencing Ready Reaction Kit reagent (Life Technologies), 1,0 $\mu \mathrm{L}$ do primer (10 pmol), 5,0 $\mu \mathrm{L}$ do produto de PCR totalizando um volume final de $10 \mu \mathrm{L}$. As leituras das reações foram feitas no sequenciador automático $A B I$ 3100 (Life Technologies).

\subsubsection{Análise das sequencias}

As sequencias foram comparadas com outras existentes no GenBank, usando o Basic Local Alignment Search Tool (BLAST) do National Center for Biotechnology Information $(N C B I)$. 


\section{RESULTADOS}

\subsection{RESULTADOS SOROLÓGICOS}

Foram analisadas ao total 1.156 amostras brasileiras pelo ELISA no CIRAD Guadelouope. Como as amostras de equídeos eram provenientes de três localidades e épocas diferentes de coleta e por esta técnica ELISA ser extremamente sensível, capaz de apresentar alterações de valores por diferenças na coleta, nos animais, locais e outros, a padronização das amostras de equídeos ocorreu em três grupos distintos, um para cada local. Já para as aves, devido à grande diversidade de animais, a padronização priorizou os grupos de aves que tinham indivíduos da mesma espécie.

Cada grupo teve a média de valores de porcentagem de inibição calculada (excluindose os valores extremos superiores e inferiores) obtida do mesmo grupo, bem como o cálculo do desvio padrão e o limiar do mesmo grupo. As amostras positivas foram aquelas que, dentro do mesmo grupo, obtiveram valor acima do limiar de detecção calculado, com ao menos, três vezes o valor do desvio padrão, conforme os exemplos ilustrados nas figuras a seguir:

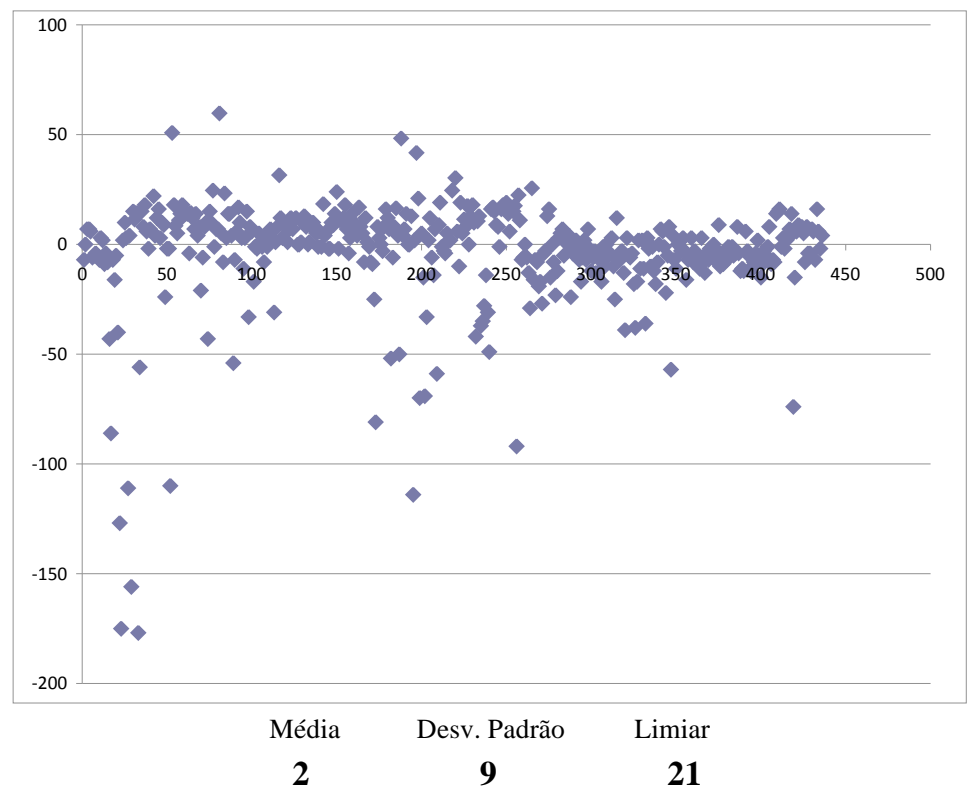

Figura 72 - Gráfico composto por resultados apresentados pelo grupo de 435 equídeos do Estado do Mato Grosso. 


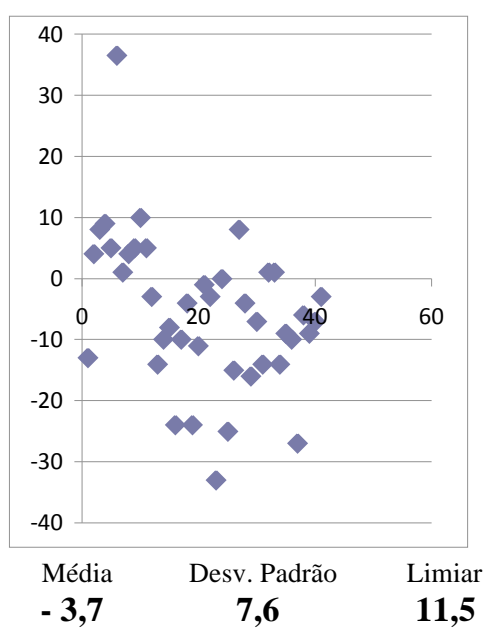

Figura 73 - Gráfico composto por resultados apresentados pelo grupo de 41 amostras de aves da espécie Arenaria interpres.

Conforme demonstrado nos gráficos anteriores, podemos observar as amostras positivas em destaque na parte superior, que possuem 3x o valor do desvio padrão estipulado, acima do limiar de detecção de cada grupo de amostras.

Após padronização, cálculo e análise dos valores das amostras de cada grupo, chegamos à conclusão que das 1.156 amostras testadas, 18 amostras apresentaram resultados positivos para a detecção de anticorpos para WNV por ELISA, dentre elas 13 amostras de equídeos e 5 amostras de aves, conforme a tabela 11.

Tabela 11 - Amostras positivas para ELISA.

\begin{tabular}{cccc}
\hline Animal & \% de Inibição & Limiar & Vezes o desvio padrão \\
\hline Cavalo & $43 \%$ & $37 \%$ & 3,9 \\
Cavalo & $51 \%$ & $30 \%$ & 5,2 \\
Cavalo & $60 \%$ & $30 \%$ & 6,2 \\
Cavalo & $32 \%$ & $30 \%$ & 3,2 \\
Cavalo & $48 \%$ & $30 \%$ & 5,0 \\
Mula & $42 \%$ & $30 \%$ & 4,3 \\
Cavalo & $30 \%$ & $30 \%$ & 3,0 \\
Cavalo & $26 \%$ & $30 \%$ & 2,5 \\
Cavalo & $39 \%$ & $39 \%$ & 3,0 \\
Cavalo & $44 \%$ & $39 \%$ & 3,5 \\
Cavalo & $64 \%$ & $39 \%$ & 5,4 \\
Cavalo & $49 \%$ & $39 \%$ & 4,0 \\
Cavalo & $35 \%$ & $39 \%$ & 2,6 \\
Dendrocygna autumnalis & $53 \%$ & $16 \%$ & 8,8 \\
Arenaria interpres & $37 \%$ & $19 \%$ & 5,3 \\
Sterna hirundo & $41 \%$ & $39 \%$ & 3,3 \\
Sterna hirundo & $37 \%$ & $39 \%$ & 2,8 \\
Sterna hirundo & $34 \%$ & $39 \%$ & 2,3 \\
\hline
\end{tabular}


Todas as amostras positivas por ELISA, foram encaminhadas ao Laboratório do Dr. Robert Lanciotti - CDC, Fort Collins - US, para a confirmação da positividade para a presença de anticorpos do WNV, através da técnica de soro-neutralização (PRNT), conforme protocolo descrito anteriormente (LEFRANÇOIS et al., 2005).

Os títulos foram expressos como a recíproca da diluição do soro rendendo $\geq 90 \%$ de redução no número de placas, em um teste de neutralização por redução de placa $\left(\mathrm{PRNT}_{90}\right)$. A amostra de soro foi considerada positiva para a presença de anticorpos WNV se positiva por ELISA de bloqueio e com título no PRNT para WNV pelo menos 4 vezes maior do que o título para o vírus da encefalite de Saint Louis (SLEV - do inglês Saint Louis encephalitis virus) correspondente. A amostra de soro foi considerada a ter anticorpos para SLEV se duvidoso ou positivo por ELISA de bloqueio com um título de PRNT para SLEV pelo menos 4 vezes maior do que o título WNV correspondente.

Das 678 amostras de equídeos, 13 (1,9\%) obtiveram resultado positivo ou duvidoso no ELISA. Os testes de neutralização confirmaram a soropositividade em todas as 13 amostras e indicou os agentes infecciosos como sendo WNV, SLEV, e Flavivirus indiferenciado em 4, 5 e 4 amostras, respectivamente. Um cavalo positivo para Flavivirus indiferenciado (em Juruena) apresentou este resultado provavelmente por estar vacinado contra Encefalite Equina do Oeste e vírus da Encefalite Equina do Leste (comunicação pessoal) '. Os títulos do PRNT de WNV ou SLEV em equídeos soropositivos variou de 40 a 2560. O SLEV foi identificado em Teodoro Sampaio - SP em 2002 e 2006, e em Juruena - MT em 2009, enquanto o WNV foi identificado em 4 equídeos (1,8\%), apenas em Nova Brasilândia - MT em 2009.

Todas as amostras de aves obtiveram resultado negativo na confirmação por PRNT, conforme resultados demonstrados na tabela a seguir e discutido no artigo publicado com tais resultados (Apêndice B):

\footnotetext{
${ }^{1}$ Informação fornecida por Prof. Dr. Daniel Moura de Aguiar, em 2010.
} 
Tabela 12 - Resultados do ELISA e PRNT. Em vermelho, as quatro amostras positivas por ELISA e confirmadas por PRNT.

\begin{tabular}{|c|c|c|c|c|c|c|c|c|c|c|c|}
\hline Espécies & $\begin{array}{c}\text { \% de } \\
\text { Inibição }\end{array}$ & Limiar & $\begin{array}{c}\text { Vezes o } \\
\text { desv. } \\
\text { padrão }\end{array}$ & $\begin{array}{c}\text { Título } \\
\text { WN }\end{array}$ & $\begin{array}{l}\text { Titulo } \\
\text { SLEV }\end{array}$ & $\begin{array}{l}\text { PRNT } \\
\text { WNV } \\
\text { SLEV }\end{array}$ & Local & $\begin{array}{c}\text { Data da } \\
\text { coleta }\end{array}$ & Idade & Identificação & Sexo \\
\hline Cavalo & $43 \%$ & $37 \%$ & 3,9 & 80 & 160 & $1 / 2$ & Monte Negro - RO & 15.06 .02 & 10 anos & 17EQ2 & $\overline{\text { Male }}$ \\
\hline Cavalo & $51 \%$ & $30 \%$ & 5,2 & 80 & 20 & 4 & Nova Brasilândia -MT & 27.04 .09 & 6 anos & MT 53 & Macho \\
\hline Cavalo & $60 \%$ & $30 \%$ & 6,2 & 160 & 320 & $1 / 2$ & Nova Brasilândia -MT & 27.04 .09 & 8 anos & MT 81 & Fêmea \\
\hline Cavalo & $32 \%$ & $30 \%$ & 3,2 & 80 & 20 & 4 & Nova Brasilândia -MT & 06.07 .09 & 5 anos & MT 116 & Macho \\
\hline Cavalo & $48 \%$ & $30 \%$ & 5,0 & 80 & 10 & 8 & Nova Brasilândia -MT & 21.09 .09 & 6 anos & MT 188 & Macho \\
\hline Mula & $42 \%$ & $30 \%$ & 4,3 & 40 & 10 & 4 & Nova Brasilândia -MT & 16.10 .09 & 8 anos & MT 197 & Macho \\
\hline Cavalo & $30 \%$ & $30 \%$ & 3,0 & 20 & 160 & $1 / 8$ & Juruena - MT & 06.11 .09 & 6 anos & MT 219 & Macho \\
\hline Cavalo & $26 \%$ & $30 \%$ & 2,5 & 1280 & 640 & 2 & Juruena - MT & 06.11 .09 & 1,4 anos & MT 264 & Macho \\
\hline Cavalo & $39 \%$ & $39 \%$ & 3,0 & 10 & 20 & $1 / 2$ & Teodoro sampaio - SP & 12.04 .02 & NA & 29EQ1 & Fêmea \\
\hline Cavalo & $44 \%$ & $39 \%$ & 3,5 & 320 & 1280 & $1 / 4$ & Teodoro sampaio - SP & 18.01 .06 & NA & RQEQ1 & Fêmea \\
\hline Cavalo & $64 \%$ & $39 \%$ & 5,4 & 160 & 2560 & $1 / 16$ & Teodoro sampaio - SP & 06.02 .06 & NA & R19EQ2 & Fêmea \\
\hline Cavalo & $49 \%$ & $39 \%$ & 4,0 & 20 & 160 & $1 / 8$ & Teodoro sampaio - SP & 17.03 .02 & NA & 42EQZ & Macho \\
\hline Cavalo & $35 \%$ & $39 \%$ & 2,6 & 40 & 160 & $1 / 4$ & Teodoro sampaio - SP & 19.03.02 & NA & 22EQ1 & Fêmea \\
\hline $\begin{array}{l}\text { Dendrocygna } \\
\text { autumnalis }\end{array}$ & $53 \%$ & $16 \%$ & 8,8 & $<20$ & $<20$ & - & Pinheiro - MA & 14.05 .10 & adulto & MA 232 & NA \\
\hline $\begin{array}{l}\text { Arenaria } \\
\text { interpres }\end{array}$ & $37 \%$ & $19 \%$ & 5,3 & $<20$ & $<20$ & - & Ilha de Canelas- PA & 25.11 .08 & Jovem & A 12 & NA \\
\hline Sterna hirundo & $41 \%$ & $39 \%$ & 3,3 & $<20$ & $<20$ & - & $\begin{array}{l}\text { Parque Nacional da } \\
\text { Lagoa do Peixe - RS }\end{array}$ & 19.11 .09 & - & PNLP 131 & NA \\
\hline Sterna hirundo & $37 \%$ & $39 \%$ & 2,8 & $<20$ & $<20$ & - & $\begin{array}{l}\text { Parque Nacional da } \\
\text { Lagoa do Peixe - RS }\end{array}$ & 20.11 .09 & - & PNLP 187 & NA \\
\hline Sterna hirundo & $34 \%$ & $39 \%$ & 2,3 & $<20$ & $<20$ & - & $\begin{array}{l}\text { Parque Nacional da } \\
\text { Lagoa do Peixe - RS }\end{array}$ & 26.03 .10 & - & PNLP 280 & NA \\
\hline
\end{tabular}

De acordo com os dados obtidos, fica confirmada a presença de anticorpos para o WNV em equídeos na região de Nova Brasilândia em 2009. Sabendo que tais equídeos nunca foram vacinados para WNV e nem saíram da região, os resultados indicam a possível circulação do vírus na região, que por ser compreendida entre os biomas Cerrado e Pantanal, nos levam à interpretação da presença viral em decorrência do potencial da região pantaneira para a passagem e estadia de aves migratórias provindas do Hemisfério Norte, bem como aves que realizam deslocamentos provindas da Argentina, local onde já foi isolado o WNV.

As amostras soropositivas foram identificadas apenas em 2009 em equídeos que variavam entre 5 a 8 anos de idade. Esses resultados, embora animadores, devem ser interpretados com cautela, uma vez que podem representar a reatividade cruzada com outras flaviviroses, pois os títulos baixos das amostras positivas para WNV possivelmente sugerem a reatividade cruzada, enquanto as amostras positivas para SLEV, que mostraram altos títulos, sugerem infecções específicas por SLEV. Assim, devemos confirmar a infecção do WNV por PRNT não só para WNV, SLEV e Flavivirus indiferenciado, como foi realizado, mas sim para outros Flavivirus descritos anteriormente no Brasil, como vírus Ilhéus, Bussuquara, Cacipacore, da Febre Amarela, da Dengue, entre outros. Mesmo o SLEV não sendo o foco deste estudo, a circulação de SLEV em Teodoro Sampaio e em Juruena foi identificada. 


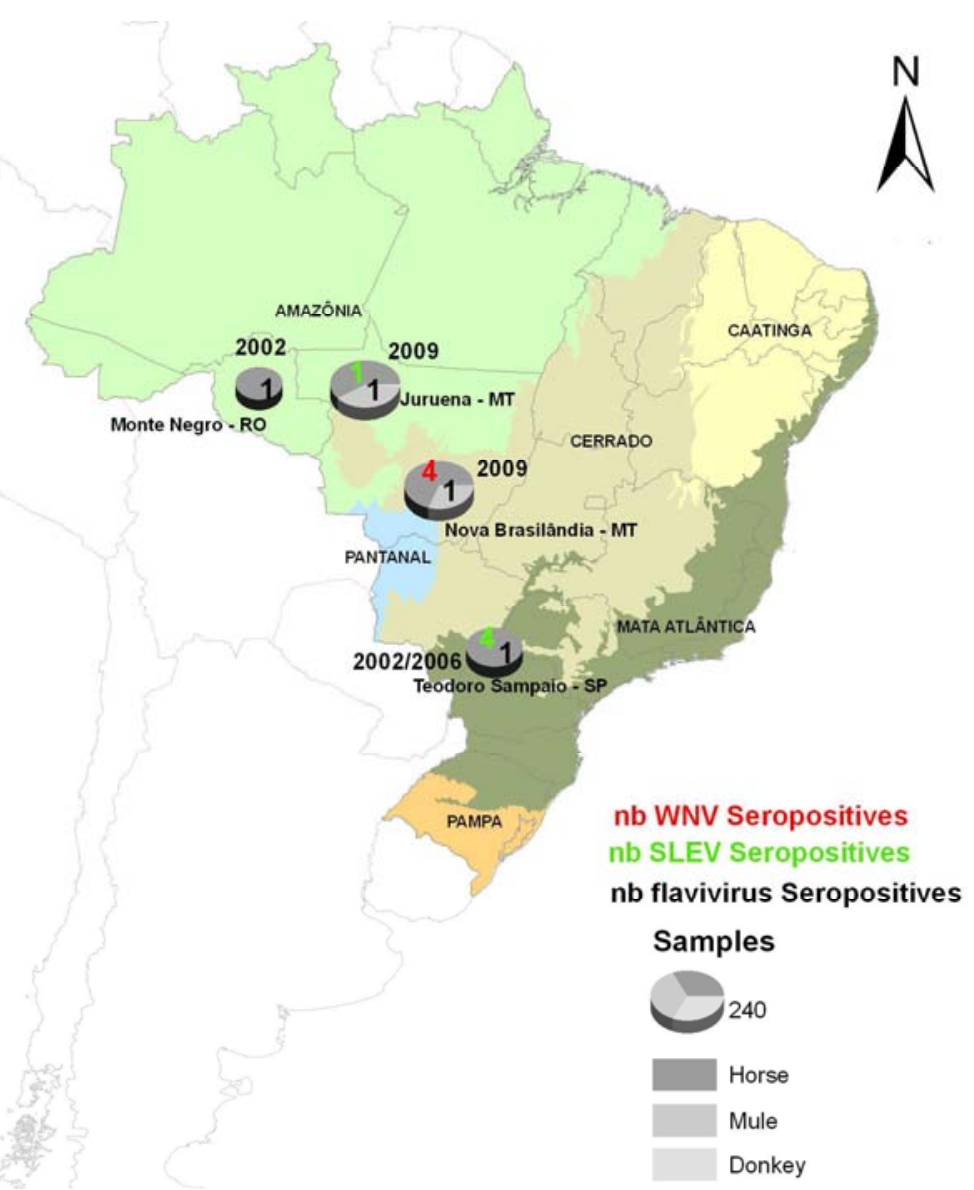

Figura 74 - Locais e data das coletas de equídeos com demonstração dos biomas brasileiros e resultados sorológicos obtidos.

Em paralelo aos testes sorológicos, analisamos as 18 amostras positivas por ELISA (13 de equídeos e 5 de aves) com o teste one-step real-time RT-PCR em nosso laboratório no Brasil, de acordo com protocolo padronizado, porém nenhuma apresentou resultado positivo para a presença do WNV.

\subsection{RESULTADOS DA BIOLOGIA MOLECULAR NO LABORATÓRIO NB3+}

\subsubsection{Avaliação da técnica de extração e PCR}

A utilização de par de primers para RNA ribossômico 16S (DESJARDINS; MORAIS, 1990; SPICER; DUNIPACE, 2004) como controle endógeno da reação, mostrou que o método de extração e a técnica de PCR foram capazes de detectar o rRNA (16S) em todas as amostras analisadas, apesar da amostra MA 157 apresentar banda de difícil visualização neste arquivo, confirmando assim que os métodos de extração estão bem estabelecidos. 


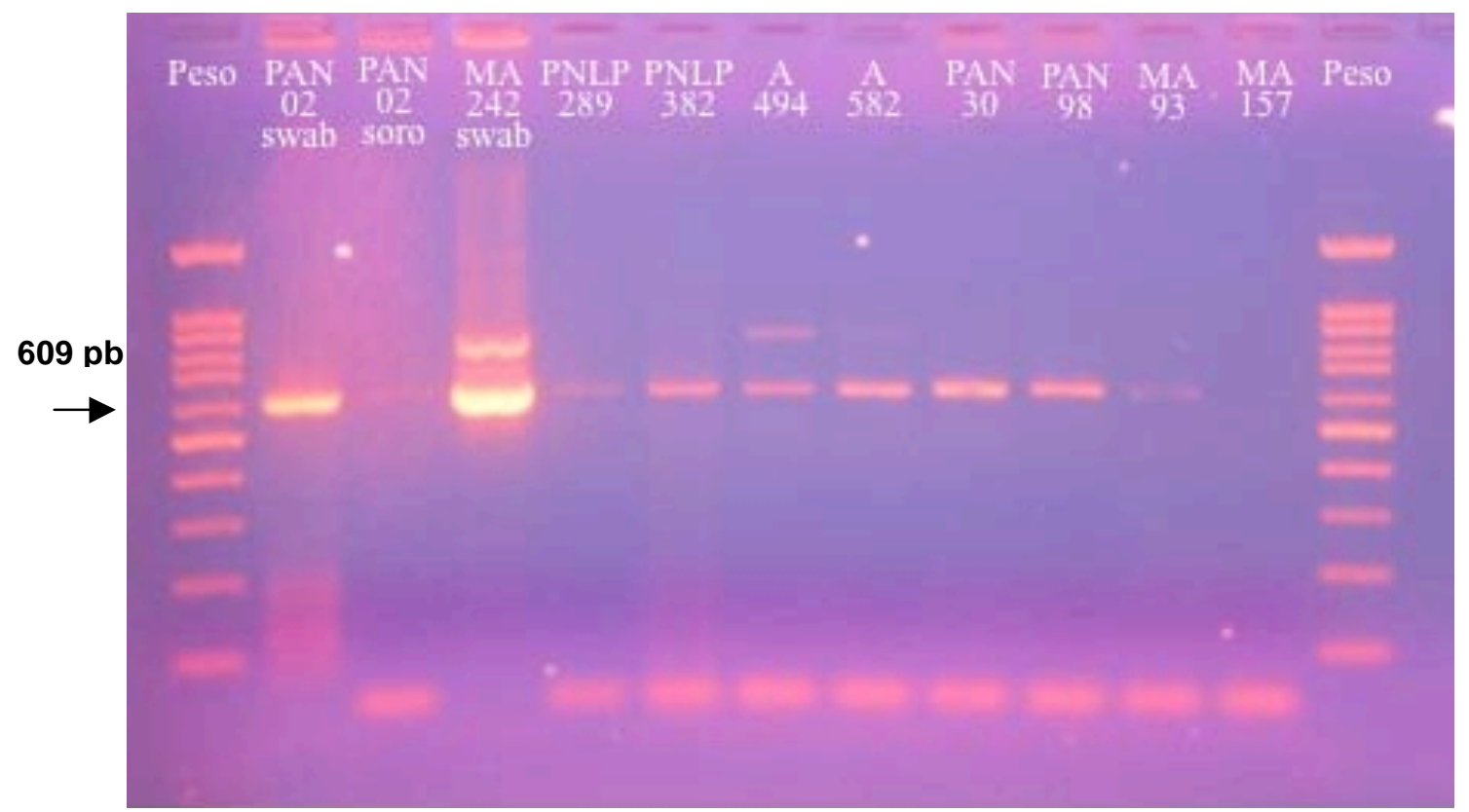

Figura 75 - Análise eletroforética em gel de agarose 2,0\%, dos produtos amplificados utilizando primers de 16S, apresentando banda de 609 pb. Peso - $1.000 \mathrm{~Kb}$ DNA Ladder (Thermo scientific - Fermentas).

Quanto à detecção molecular, o método demonstrou resultados satisfatórios, sendo possível detectar os controles positivos de diferentes cargas virais utilizando os primers projetados para o WNV observando a curva de amplificação. Controles com diferentes cargas virais foram utilizados na padronização do teste (Figura 76).

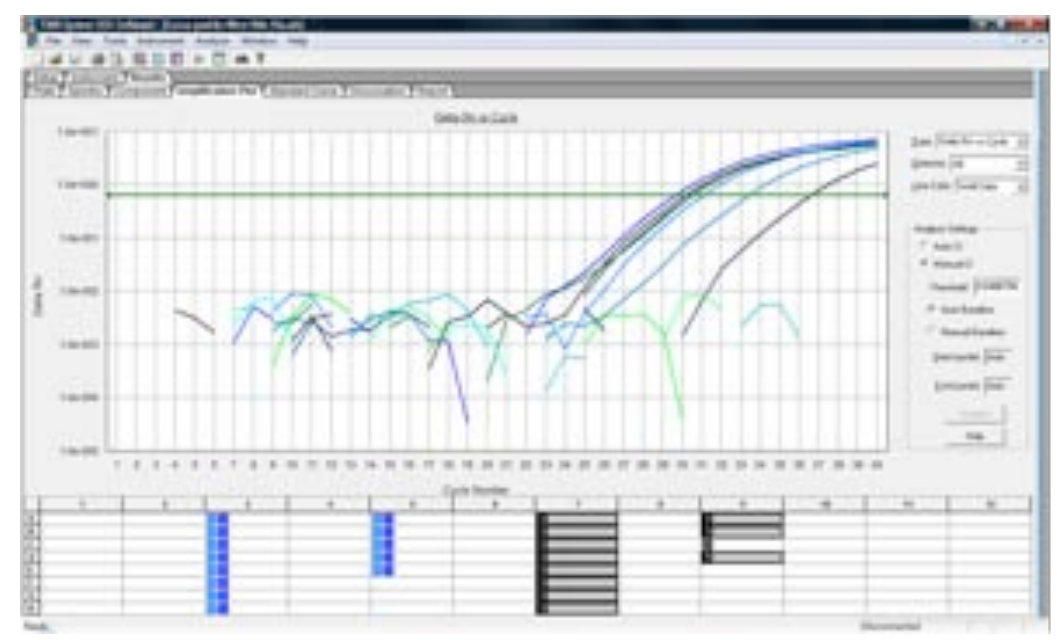

Figura 76 - Curva de amplificação dos controles positivos. O eixo x representa o número de ciclos e o eixo y, representa a quantidade de fluorescência emitida.

Observamos que o teste foi bem sucedido, pois conseguimos a detecção nos soros contendo o vírus. Testamos em amostras de diferentes cargas virais e foi possível detectar em 8 das 10 amostras analisadas, pois duas delas que continham $<100$ e $<5$ cópias, não foram 
detectadas, provavelmente por sua baixa carga viral, sugerindo o limiar de sensibilidade do teste padronizado.

Com o teste já padronizado e em pleno funcionamento, analisamos um total de 3.445 amostras de aves, 828 amostras de equídeos, 24 amostras de morcegos e 11 amostras de onças, provenientes de diversas regiões, como apresentado no apêndice A.

As amostras de equídeos que não foram analisads pelo teste molecular automatizado, do total de 828 soros, foram submetidas à extração e RT-PCR em formato de pools. Cada pool foi composto por 6 amostras, sendo $40 \mu \mathrm{L}$ de cada, totalizando $240 \mu \mathrm{L}$, quantidade de material suficiente para a realização da extração e detecção, mais uma repetição, se necessário. Foram testados o total de 95 pools do MT, 26 pools de SP e 16 pools de RO.

Para garantir que a sensibilidade do teste não fosse alterada, realizamos uma curva de diluição gradativa nos controles positivos, testados no mesmo formato de pools. $\mathrm{O}$ resultado foi plenamente satisfatório, como demonstra a figura 77.

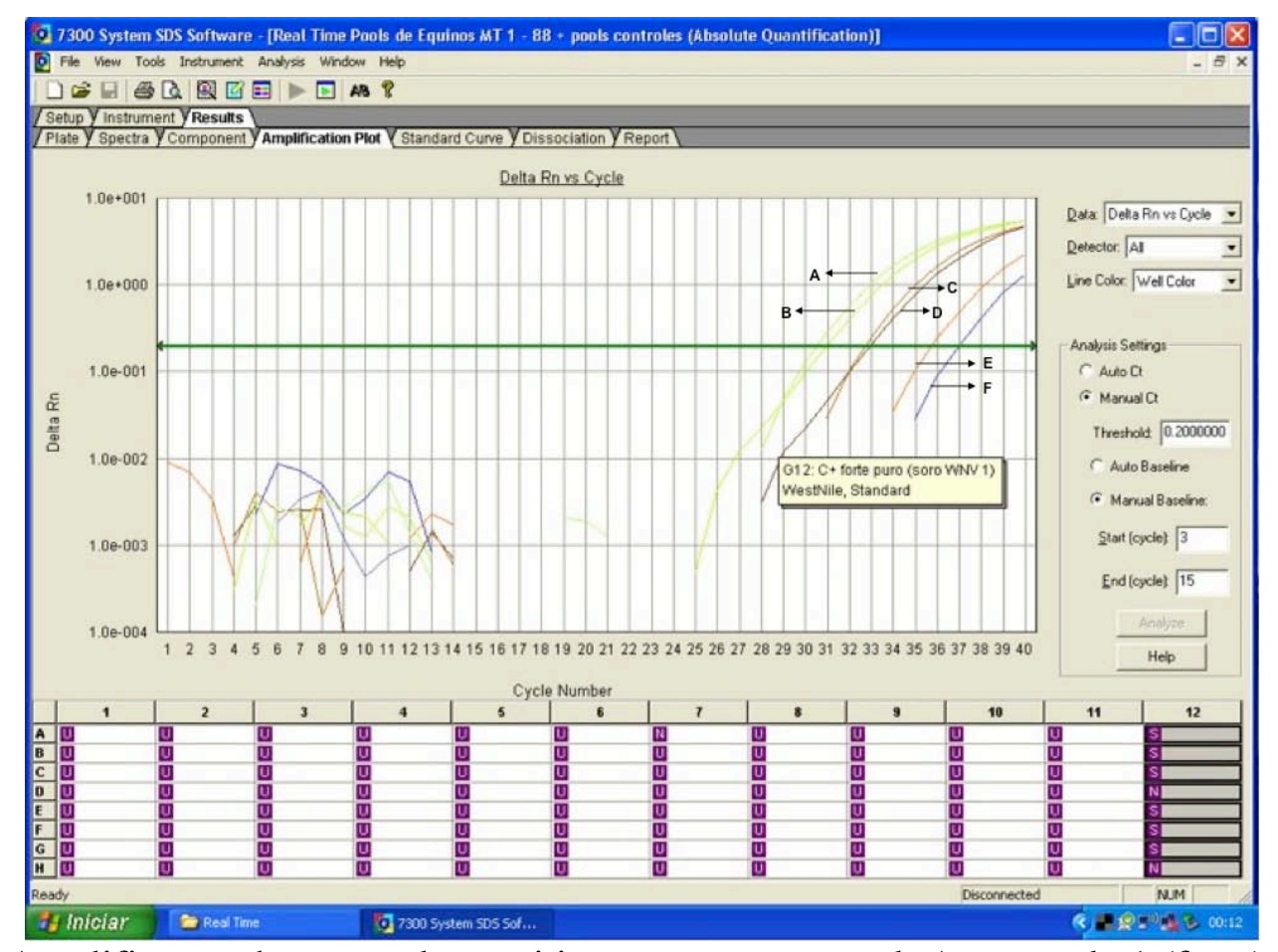

Figura 77 - Amplificação dos controles positivos puros e em pool: A- controle 1 (forte) puro; B- controle 10 (médio) puro; C- controle 1 (forte) pool; D- controle 10 (médio) pool; E- controle 9 (fraco) puro; F- controle 9 (fraco) pool.

Das amostras analisadas no laboratório $\mathrm{BSL}^{+}$, observamos que os testes foram bem sucedidos, pois conseguimos a detecção no soro que contém o vírus (controles positivos inativados) em todas as placas testadas, conforme gráfico representativo abaixo. 


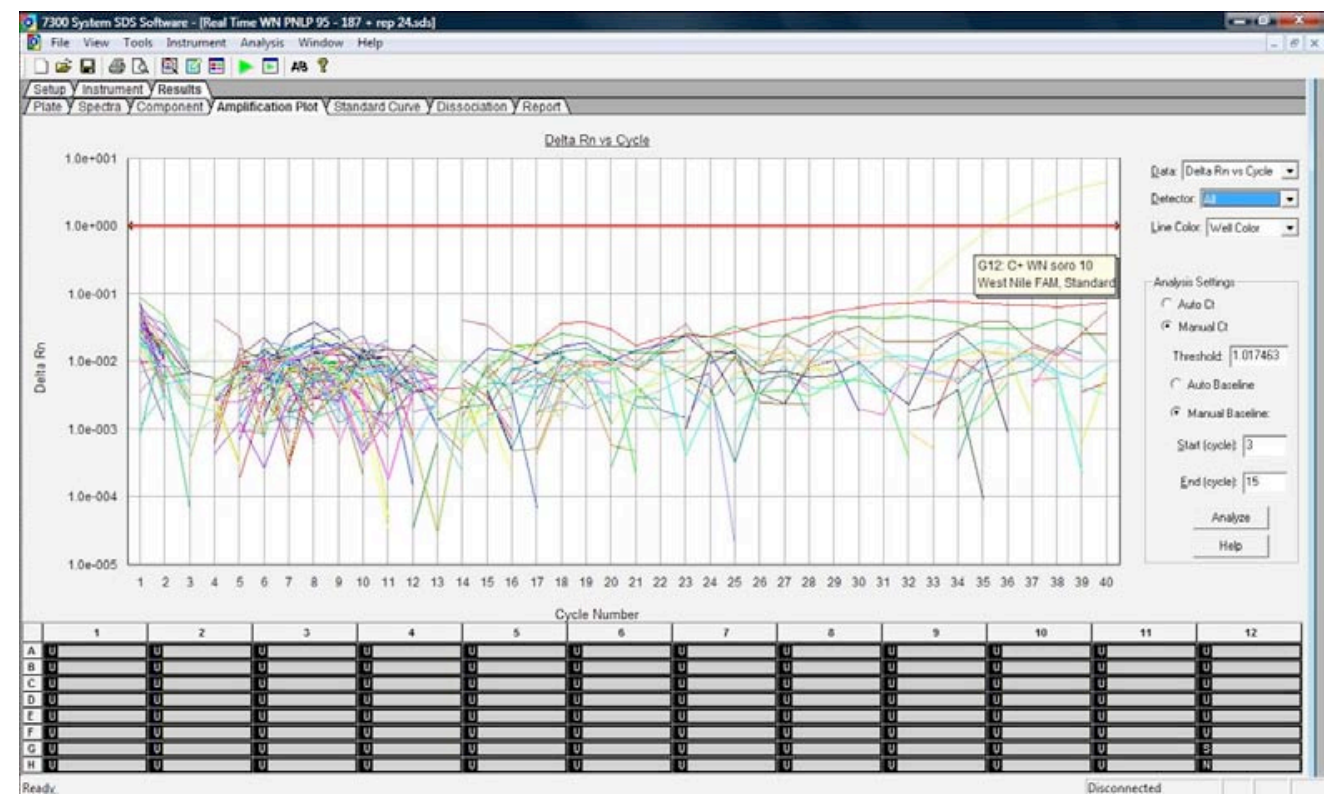

Figura 78 - Gráfico de one-step real-time RT-PCR das amostras do PNLP, com curva de amplificação do controle positivo.

Das 4.308 amostras testadas pelo método molecular em laboratório $\mathrm{NB}^{+}$, apenas uma (MA242) proveniente das Reentrâncias Maranhenses, estado do Maranhão, apresentou positividade para a presença do WNV, como mostra o gráfico a seguir:

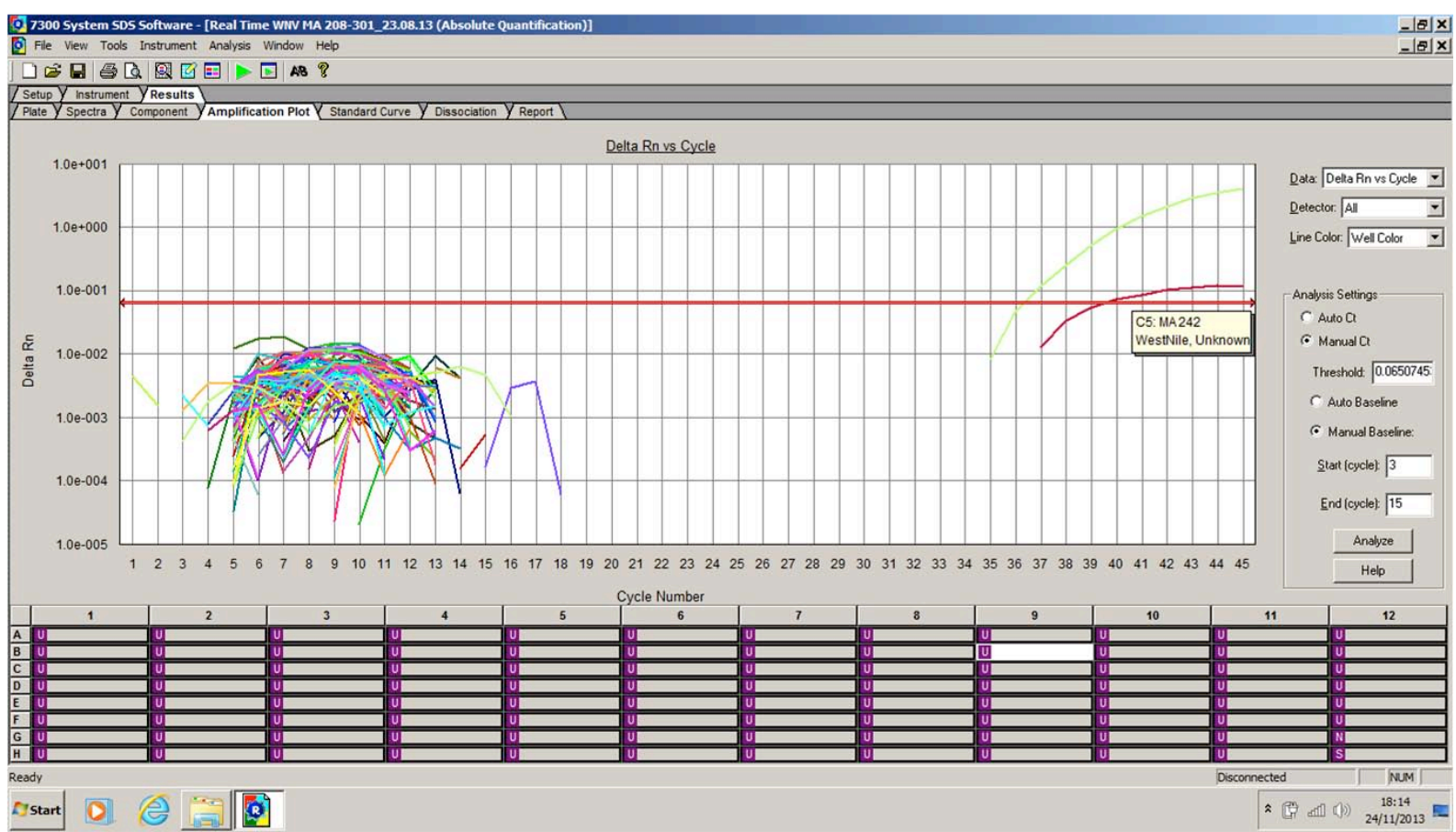

Figura 79 - Gráfico de one-step real-time RT-PCR das amostras de aves do Maranhão com curva de amplificação do controle positivo e da amostra MA242.

A amostra MA 242 foi coletada de uma Dendrocygna autumnalis em Pinheiro - MA na data de 14/05/2010 e vem de encontro com os testes sorológicos previamente apresentados, 
que demonstrou positividade sorológica para o ELISA na amostra MA 232, também coletada de uma Dendrocygna autumnalis na mesma data e região da amostra anteriormente citada, mas que não apresentou positividade na confirmação por $\operatorname{PRNT}_{90}$.

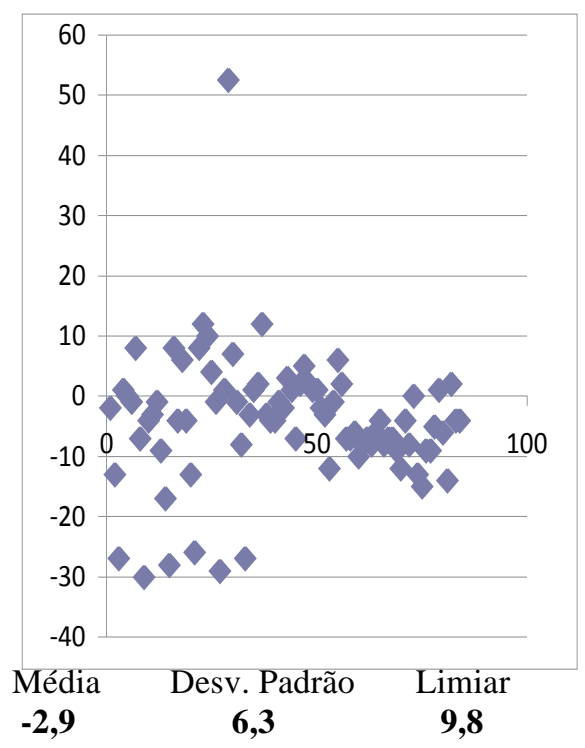

Figura 80 - Gráfico composto por resultado do ELISA, do grupo com total de 84 amostras de aves da espécie Dendrocygna sp, sendo a amostra MA 232 em destaque acima do grupo base de resultados.

Tabela 13 - Resultado sorológico da amostra MA232.

\begin{tabular}{ccccccc}
\hline $\begin{array}{c}\text { Local } \\
\text { coordenadas geográficas }\end{array}$ & $\begin{array}{c}\text { Data da } \\
\text { coleta }\end{array}$ & Espécie & $\begin{array}{c}\text { Inibição } \\
\text { ELISA 3.112G }\end{array}$ & $\begin{array}{c}\text { PRNT } \\
\text { WNV } \\
\text { título }\end{array}$ & $\begin{array}{c}\text { PRNT } \\
\text { SLEV } \\
\text { título }\end{array}$ & $\begin{array}{c}\text { Diagnóstico } \\
\text { PRNT }\end{array}$ \\
\hline $\begin{array}{c}\text { Pinheiro-MA }-\mathrm{MA} 2^{\circ} 31^{\prime} 22,64 " \\
\mathrm{~W} 45^{\circ} 05^{\prime} 33,23^{\prime \prime}\end{array}$ & $14 / 05 / 10$ & Dendrocygna autumnalis (bird) & $53 \%$ & $<20$ & $<20$ & negative \\
\hline
\end{tabular}

\subsection{RESULTADOS DA BIOLOGIA MOLECULAR AUTOMATIZADA}

O sistema automatizado de PCR em tempo real descrito, foi adotado para avaliação das amostras de soro de equídeos provenientes do estado do Mato Grosso e macerados de cérebro provenientes do Instituto Biológico, em adição às amostras utilizadas nos testes anteriores.

O teste funcionou, com a detecção tanto do controle interno da reação quanto do controle viral positivo, ambos provenientes do kit, como também o controle positivo de WNV utilizado normalmente em laboratório BSL3. Porém, apesar da grande sensibilidade do teste, todas as 479 amostras testadas foram negativas para a presença do vírus. 

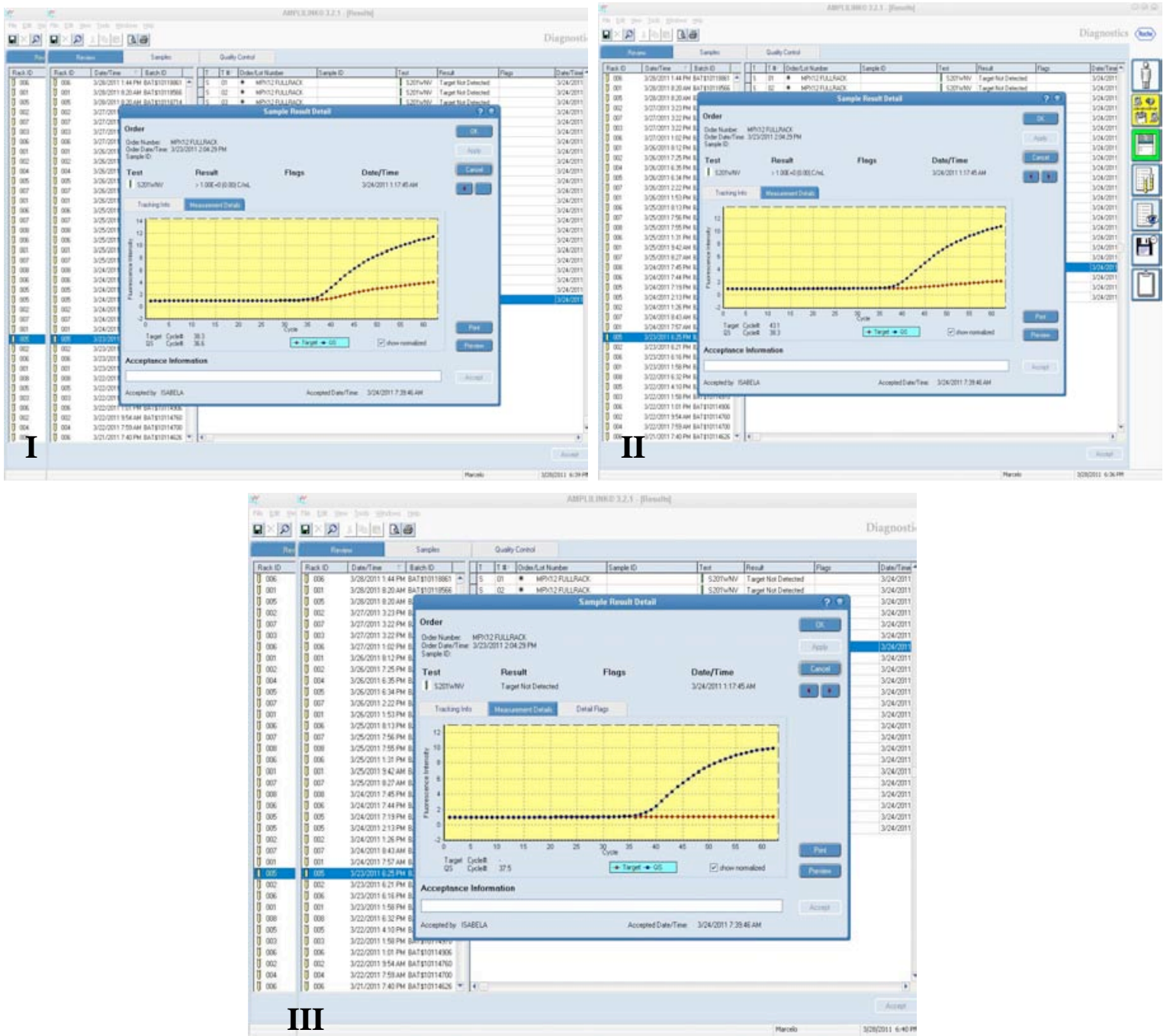

Figura 81 - (I) Gráfico do resultado do controle positivo do kit, (II) gráfico do resultado do controle positivo do estudo, (III) gráfico de amostra negativa. A curva azul representa o controle interno da reação e a curva vermelha, a detecção ou não do vírus nos controles e amostra.

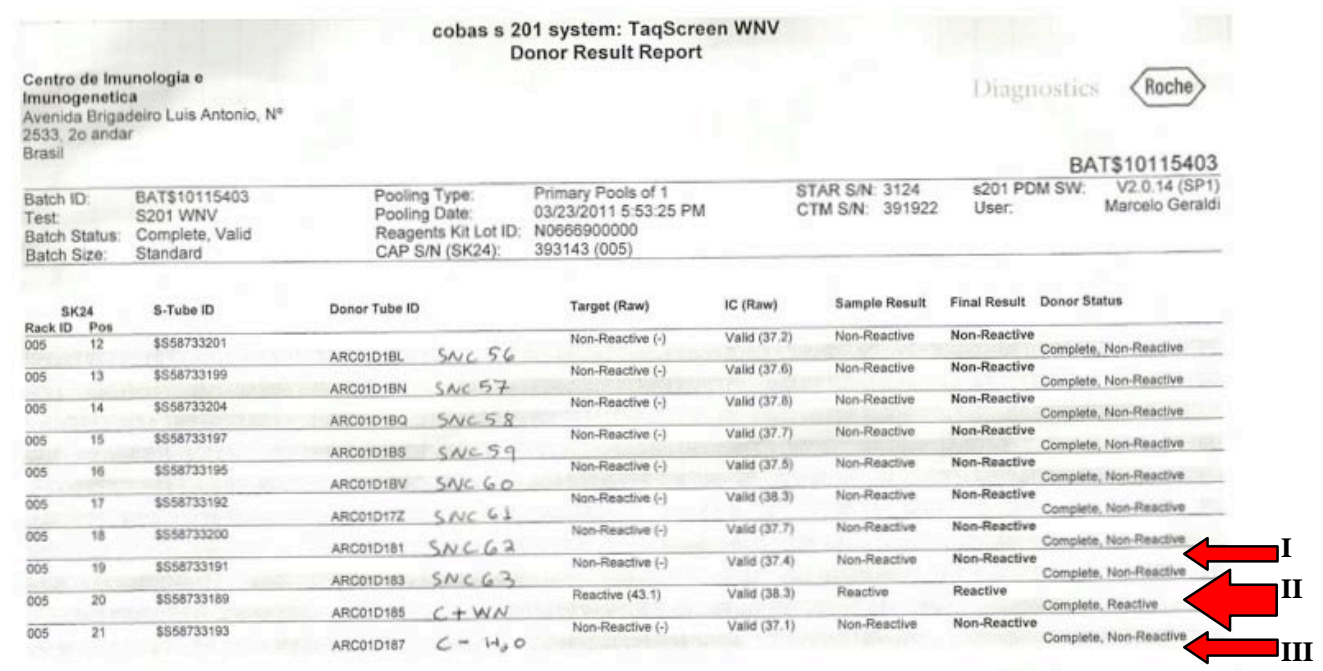

Figura 82 - Relatório de resultados com (I) amostras de cérebros - não reativos; (II) controle positivo de WNV - reativo; (III) controle negativo - não reativo. 


\subsection{RESULTADOS DA BIOLOGIA MOLECULAR EM CAMPO}

Considerando os fatores de risco eminentes no Brasil, a circulação do WNV pode se tornar endêmica. As possíveis consequências para a saúde pública, econômica e ambiental, enfatizam a necessidade de estudos complementares para identificar áreas de risco com agilidade e confiabilidade, itens presentes no método de detecção em campo padronizado.

Os controles positivos utilizados no desenvolvimento deste estudo funcionaram perfeitamente, mantendo o mesmo padrão de detecção que nos outros métodos moleculares, mostrando que a sensibilidade do teste não foi alterada independente das estruturas utilizadas. Porém, nenhuma das 16 amostras coletadas na expedição do PNLP que foram submetidas ao teste foi positiva para a presença viral. As amostras para o teste em campo foram triadas na base laboratorial do acampamento de acordo com animais que apresentavam sinais clínicos de debilidade e/ou qualquer outra manifestação que tornou-se interessante à análise imediata do indivíduo.

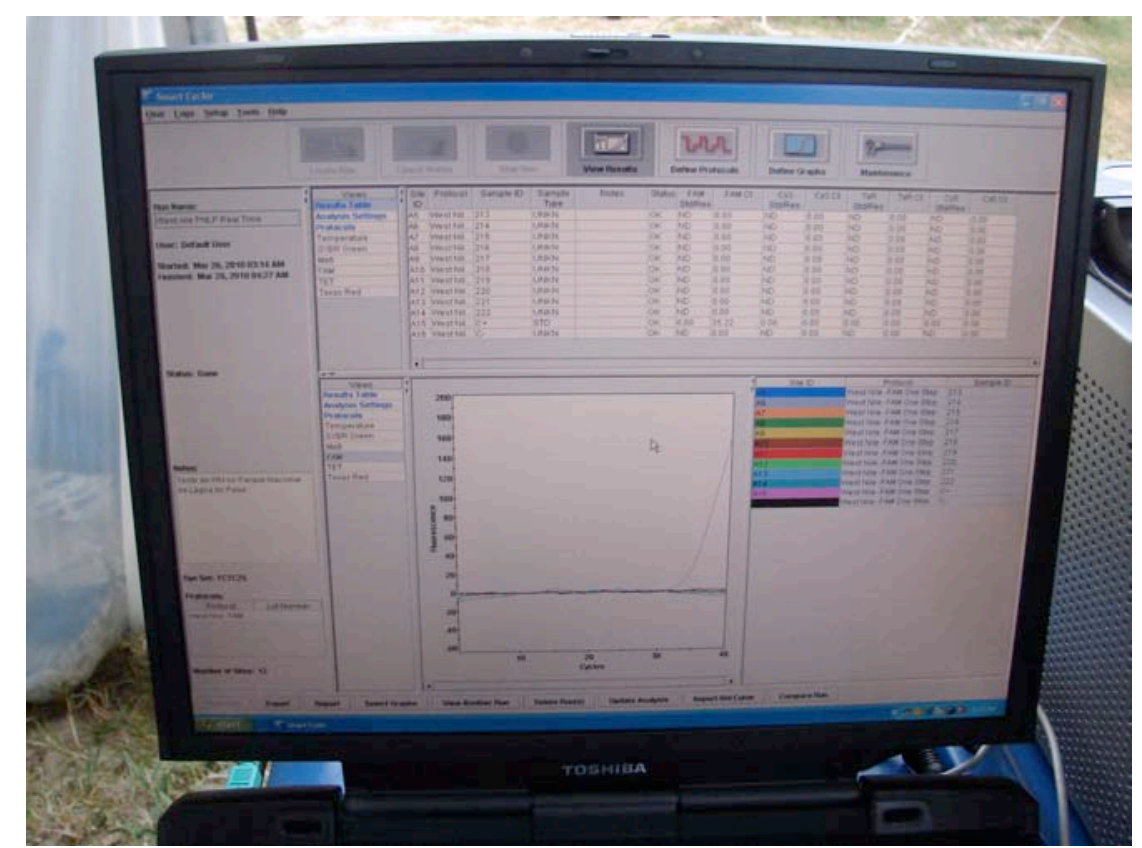

Figura 83 - Tela de resultado do one-step real-time $R T$ - PCR em campo, sendo que a curva vermelha no final do ciclo representa a detecção viral do controle positivo utilizado.

Fonte: (EQUIPE DE CAMPO, 2013)

A reação possui alta sensibilidade, é simples e rápida e além disso, os resultados podem ser visualizados em apenas uma hora. Apesar de na ocasião não terem sido detectadas amostras positivas, o teste foi realizado em perfeitas condições e poderá ser reproduzido em qualquer lugar do país, como foi o caso da expedição para o Pantanal mato-grossense 
realizada em dezembro de 2012. Novamente levamos os equipamentos necessários e conseguimos mais uma vez realizar o teste molecular em campo com sucesso em 26 amostras (19 aves e 7 equinos) e obtivemos uma amostra suspeita pela metodologia molecular para a presença do WNV, a PAN 02, que é amostra de um passeriforme silvestre residente, o Certhiaxis cinnamomeus.

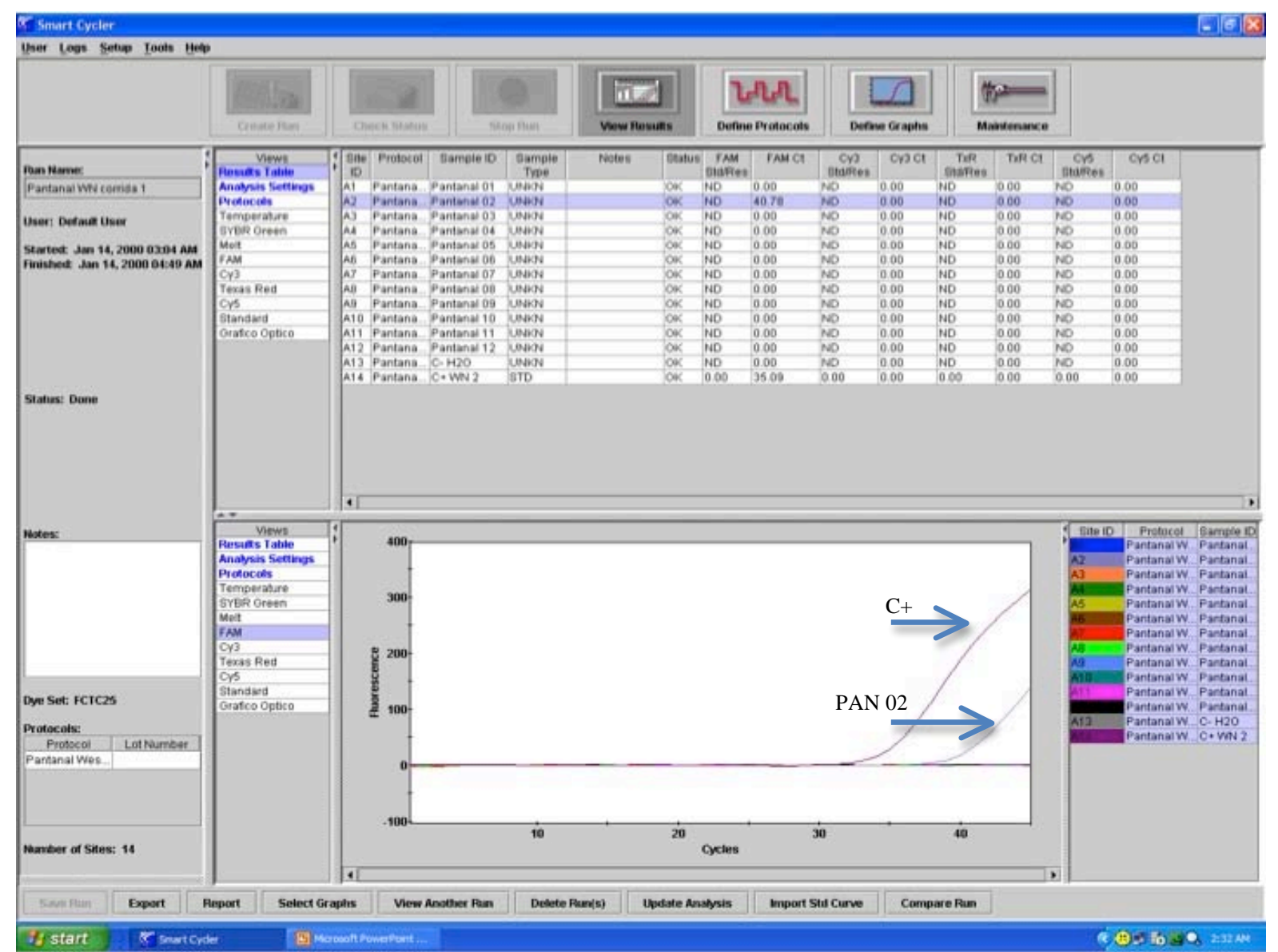

Figura 84 - Curva de amplificação de one-step real-time RT-PCR em campo da amostra suspeita.

\subsection{CULTURA CELULAR}

Com o intuito de isolar e posteriormente sequenciar a amostra PAN 02, suspeita para a presença do RNA viral, encaminhamos uma alíquota da amostra para isolamento, como descrito anteriormente. Após três passagens celulares foi possível a confirmação de efeito citopático sugestivo de presença viral nesta amostra, de acordo com as informações forncedicas pela Me. Telma, sendo que o passo seguinte para a identificação do agente foi a caracterização por sequenciamento genético. 


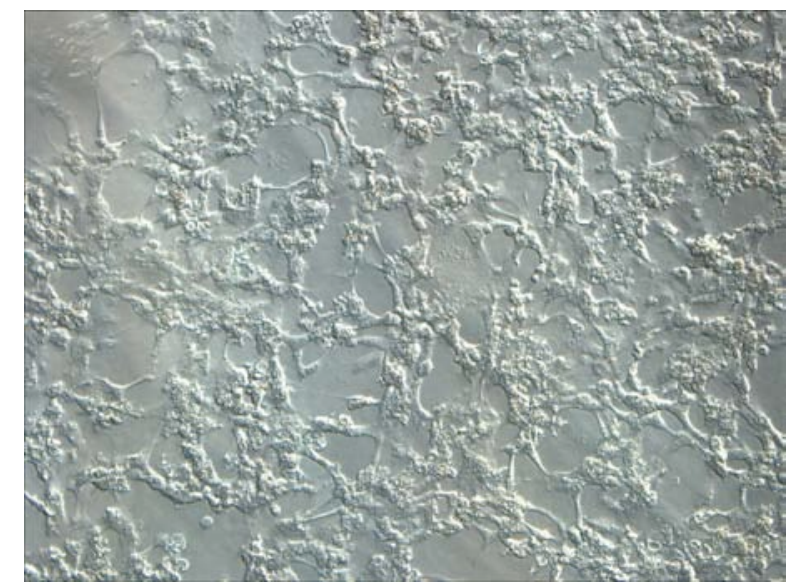

Figura 85 - Foto do efeito citopático da cultura celular da amostra PAN02. Fonte: Arquivo pessoal

\subsection{CONFIRMAÇÃO DAS AMOSTRAS POSITIVAS}

\subsubsection{PCR convencional}

Os primers genéricos utilizados na detecção dos Flavivirus (A) (FULOP et al., 1993) amplificou banda de $350 \mathrm{pb}$ aproximadamente na amostra MA242, apesar de não serem observadas bandas nos controles positivos do vírus da Dengue, da Febre Amarela e WNV.

Utilizando primers específicos (B) (MOUREAU et al., 2007) foi possível observar amplificação da amostra PAN 02, proveniente de cultura celular ( $2^{\circ}$ passagem $)$, de $270 \mathrm{pb}$ aproximadamente, juntamente com os controles positivos de Dengue e Febre Amarela. O controle positivo de WNV, não apresentou banda visível.

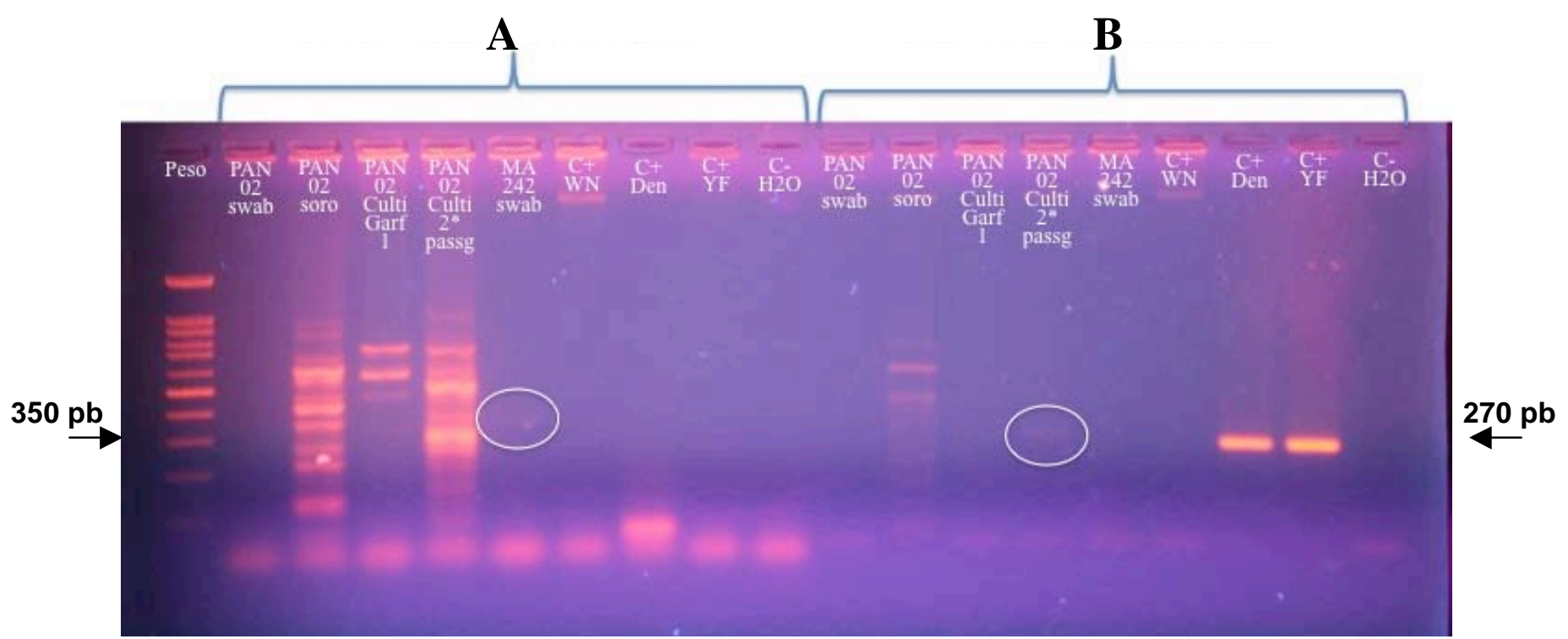

Figura 86- Análise eletroforética em gel de agarose 2,0\%, dos produtos amplificados. Aamplificação utilizando primers segundo FULOP et al., 1993. B- amplificação 
utilizando primers segundo MOUREAU et al., 2007 - modificado. Peso- $1 \mathrm{~Kb}$ DNA Ladder (Thermo Scientific - Fermentas). Os círculos indicam os fragmentos amplificados de 350 e 270 pb respectivamente. Como controle negativo, foi utilizado água (C-). Para controle positivo $(\mathrm{C}+)$ foram utilizados amostras de cultura de vírus da Dengue, Febre amarela e soro inativado do Vírus do Oeste do Nilo.

\subsubsection{Análise de sequencias}

As amostras suspeitas amplificadas não apresentaram sequências para análise, porém, as sequências obtidas dos controles positivos foram alinhadas e comparadas com outras no banco de dados gerando porcentagens de similaridade entre nucleotídeos, como demonstradas a seguir.

Tabela 14 - Análise das sequências de nucleotídeos dos controles positivos sequenciados comparada com outras sequências disponíveis no Genbank.

\begin{tabular}{|c|c|c|c|c|}
\hline $\begin{array}{l}\text { Controle } \\
\text { positivo }\end{array}$ & Nome da sequência alinhada & Identidade & Gaps & Acesso \\
\hline WNV & $\begin{array}{c}\text { West Nile virus isolate BSL24-11, } \\
\text { complete genome }\end{array}$ & $271 / 271(100 \%)$ & $0 / 271(0 \%)$ & JQ700441.1 \\
\hline $\begin{array}{l}\text { Febre } \\
\text { Amarela }\end{array}$ & $\begin{array}{c}\text { Yellow fever virus strain } \\
\text { YF/Vaccine/USA/Sanofi-Pasteur-17D- } \\
\text { 204/UF795AA/YFVax, complete genome }\end{array}$ & $269 / 269(100 \%)$ & $0 / 269(0 \%)$ & JX503529.1 \\
\hline Dengue & $\begin{array}{c}\text { Dengue virus } 3 \text { isolate } \\
\text { DENV3/BR/D3LIMHO/2006, } \\
\text { complete genome }\end{array}$ & 263/268 (98\%) & $1 / 268(0 \%)$ & JN697379.1 \\
\hline
\end{tabular}

Ao todo, neste trabalho foram analisadas 4.787 amostras. Dentre elas, utilizando métodos sorológicos, 18 apresentaram resultados positivos para a presença de anticorpos para WNV, sendo que quatro amostras de equídeos foram confirmadas por PRNT $_{90}$. Nos testes moleculares, duas amostras de aves silvestres apresentaram resultados positivos. 


\section{DISCUSSÃO}

As doenças infecciosas emergentes representam hoje uma ameaça crescente e muito significativa à saúde global, destacando-se a importância da compreensão destes fatores que envolvem o contato entre animais silvestres e seres humanos, para que possam ser desenvolvidas ações preditivas para as doenças emergentes (JONES et al., 2008), como no caso da Febre do Oeste do Nilo no Brasil. Por não se prever onde e quando o WNV aparecerá, componentes do sistema de saúde devem estar preparados para o rápido monitoramento e sistemas de detecção clínica no local (LANCIOTTI et al., 1999), fato que vem de encontro à tecnologia padronizada por nosso grupo no decorrer deste estudo.

Outro atual fator limitante para o desenho epidemiológico das doenças emergentes são as alterações climáticas, pois também é um fator de confusão que deve ser levado em conta no que diz respeito ao potencial de estabelecimento e propagação das doenças transmitidas por vetores (ARTSOB et al., 2009), bem como a migração das aves que também é impulsionada em parte por fatores climáticos sazonais, qualquer alteração nas condições climáticas podem alterar a direção e a intensidade de propagação de tais doenças (PINTO et al., 2008). O ano de 2012 teve aumento significativo dos casos de WNV nos Estados Unidos, devido provavelmente às temperaturas elevadas e à quantidade de chuva que favoreceu a multiplicação anormal de mosquitos, levando à elevação da ocorrência de casos da febre do Oeste do Nilo em humanos, mobilizando todo o sistema de saúde americano com 5.300 casos e 243 óbitos (CDC, 2013).

Aproveitando as oportunidades ambientais, o WNV tem um grande potencial para evoluir e se transformar, assim como outros vírus de RNA, e tornar-se ainda mais eficiente na disseminação para novas áreas. De fato, na última década, aumentou drasticamente sua distribuição geográfica e tem demonstrado maior patogenicidade para as aves e hospedeiros mamíferos, incluindo os seres humanos. Os fatores virais incluem a adaptação genética, tanto para o aumento de replicação em aves hospedeiras, quanto à maior variedade de mosquitos vetores competentes (MONINI et al., 2010). Desastres naturais, particularmente os eventos meteorológicos, como ciclones, furacões e inundações, geralmente afetam os locais de criação dos vetores e a transmissão vetorial da doença. O desenvolvimento do El Ninõ (corrente oceânica quente da costa sul-americana) também pode ter implicações importantes para a saúde pública global. A experiência recente com a disseminação e o estabelecimento do WNV no Hemisfério Ocidental e os vírus Chikungunya e Bluetongue na Europa, devem ser vistos como outra chamada de alerta em relação ao potencial para o surgimento de doenças 
transmitidas por artrópodes como ameaças potencialmente graves à saúde pública nas regiões de latitudes temperadas da América do Norte e Europa ocidental (ARTSOB et al., 2009).

Até o momento da escrita deste estudo, o Brasil não apresentou resultados de isolamento para o vírus, que pode manter-se silencioso devido à proteção imune das aves nativas decorrente de reação por infecções por outros Flavivirus ou à especificidade de um vetor ponte que se alimente de sangue de aves, humanos e cavalos (FIGUEIREDO, 2007). A grande variedade de possíveis hospedeiros e vetores do vírus, e a capacidade do vírus em transmissão vertical em mosquitos e horizontal em aves e mamíferos, garantem que este patógeno continuará a persistir e se proliferar nas Américas (ARTSOB et al., 2009), porém, a diversidade de espécies de aves em regiões tropicais inclui muitas que não são bons hospedeiros amplificadores do WNV. Portanto, mosquitos que se alimentam destas espécies são menos propensos a se infectar, reduzindo a probabilidade de grande amplificação viral entre os mosquitos e populações de aves, com correspondente diminuição da probabilidade de ocorrência de grande número de casos em humanos (ARTSOB et al., 2009).

Interessante e curioso, é o fato de que até agora houveram apenas raros casos documentados da doença neurológica grave e fatal associada à infecção pelo WNV em humanos e equinos na América do Sul e no Caribe, corroborando com os resultados apresentados por (GERALDI, 2012), que utilizando o teste molecular automatizado Cobas ${ }^{\circledR}$ TaqScreen WNV (Roche) analisou um total de 5.595 amostras humanas de diferentes pontos do Brasil (2.202 amostras de doadores de sangue do Amazonas, 3.144 de doadores do Mato Grosso do Sul, líquido cefalorraquidiano de 51 pacientes com suspeita de meningoencefalite viral provenientes do Hospital das Clínicas - SP e soro de 198 pacientes com síndrome febril aguda, negativos para dengue e malária provenientes da Fundação de Medicina Tropical de Manaus), sendo que não foi detectado o RNA viral do WNV em nenhuma das amostras analisadas (LEVI et al., 2011), mesmo que as prevalências sejam de 1.49 (2003) e 0.44 (2004) em 10.000 amostras de doadores de banco de sangue dos Estados Unidos, um país que o WNV já está estabelecido (STRAMER et al., 2005).

No Brasil, existe forte programa de vacinação para a Febre Amarela, além do vírus da dengue ser endêmico. Assim, o vírus da Febre Amarela e os quatro subtipos de vírus da Dengue podem conferir imunidade cruzada para outros Flavivirus, com a possível consequência de que o WNV possa vir a causar apenas infecções sub-clínicas. Estes fatos corroboram com a ausência de casos clínicos da doença no Brasil.

Pelo menos, parte desse fenômeno pode ser atribuído à vigilância limitada e à baixa capacidade de diagnóstico. Além disso, nos programas de controle de vetores, há defasagem 
de pessoal, equipamentos e ferramentas em grande parte das regiões que necessitam deste controle (ARTSOB et al., 2009). A prevenção de doenças por arbovírus depende da comunidade e esforços domésticos para reduzir a densidade do vetor (aplicação de inseticidas e redução do número de criadouros de mosquitos locais), medidas de proteção individual para diminuir a exposição aos mosquitos (uso de repelentes e camisas de mangas compridas e calças compridas) e doadores de sangue de triagem, evitando o alastramento da epidemia e controlando os fatores de risco para a disseminação viral (CDC, 2012).

Neste trabalho, a soroprevalência de WNV em equídeos em Nova Brasilândia foi de 1,8\%, que pode ser comparada com a primeira identificação de WNV em Yucatán, México $(1,2 \%)$ (LOROÑO-PINO et al., 2003). No entanto, é menor do que a soroprevalência observada em Guadeloupe após o estabelecimento do ciclo de WNV (19,3\%) (LEFRANÇOIS et al., 2005) ou no México, em áreas com histórico de encefalite clínica (22\%) (ESTRADAFRANCO et al., 2003). Isto pode ser devido a recente introdução de WNV na área em que foi detectado. A ausência de equídeos soropositivos em amostras coletadas anteriormente a 2009 não prova que o WNV não circulava neste período, pois não foram realizadas amostragens nas mesmas áreas em épocas anteriores.

Apesar de duas áreas do Estado do Mato Grosso terem sido amostradas durante o mesmo período, com uma população de amostragem semelhante (Juruena 217 indivíduos e Nova Brasilândia 218 indivíduos), a circulação do WNV só pode ser evidenciada em Nova Brasilândia. Isto pode ser relacionado a determinadas características ambientais e ecológicas, como predominância de aves migratórias nesta área, provenientes da América do Norte rumo à região do Pantanal (NUNES; TOMAS, 2008). Esta região é caracterizada por perturbação antrópica com forte expansão recente da agricultura, envolvendo atividades humanas ligadas ao desmatamento. Estes fatores podem interferir no ciclo natural do vírus, aumentando o risco de transmissão do WNV ao ser humano. Porém, a ausência de detecção de WNV em Juruena também pode estar relacionada ao baixo nível da prevalência do vírus na região.

O SLEV foi recentemente encontrado circulando no Pantanal Sul com uma soroprevalência de 43,7\% sobre equinos não-vacinados (PAUVOLID-CORRÊA et al., 2010). O nível de prevalência de SLEV em nosso estudo não pode ser avaliado, pois apenas as amostras positivas ou duvidosas para o ELISA - WNV foram testadas por PRNT. Mas, o fato de que o WNV só foi encontrado no Estado do Mato Grosso e SLEV apenas no Estado de São Paulo, pode ser devido à existência de vetores e reservatórios específicos nestas áreas.

$\mathrm{O}$ teste $\mathrm{PRNT}_{90}$ foi designado para identificar anticorpos humanos e animais que demonstrassem infecção clínica, sendo que este teste tem baixa sensibilidade em animais com 
infecções sub-clínicas. Apesar disso, o teste foi utilizado em nosso estudo apenas como método de confirmação das amostras positivas para ELISA. Sabendo que o ELISA é o único teste usado para monitoramento e detecção de anticorpos para WNV nos países da América do Norte, Central e Caribe (ADRIÁN DIAZ et al., 2008; BLITVICH et al., 2003, 2003; BOSCH et al., 2007; DE FILETTE et al., 2012; ESTRADA-FRANCO et al., 2003; LEFRANÇOIS et al., 2005; LOROÑO-PINO et al., 2003; MATTAR et al., 2005; PAUVOLID-CORREAA et al., 2011), escolhemos o PRNT ${ }_{90}$ como teste confirmatório do ELISA. Pareceu mais lógico usar um método mais específico, pois nossa intenção era evitar resultados falso-positivos e reações cruzadas no ELISA, já que o Brasil é um país livre de WNV e resultados positivos poderiam desencadear implicações políticas.

O ELISA utilizado neste estudo foi realizado com o anticorpo monoclonal, mAb 3.112G, que pode discriminar infecções de WNV e SLEV. Este ensaio de bloqueio fornece diagnóstico para vigilância de forma rápida, confiável e de baixo custo para o monitoramento da atividade do WNV em diversas espécies animais (BLITVICH et al., 2003).

Porém, uma das limitações deste trabalho foi não termos realizado o $\mathrm{PRNT}_{50}$ nas amostras de aves positivas por ELISA e negativas por PRNT $_{90}$. Por conta disso, provavelmente estamos subestimando a circulação de WNV nas aves no Brasil, dada a baixa sensibilidade para a detecção de anticorpos em animais que não apresentam sinais clínicos, mesmo que estejam infectados e com quadro sub-clínico.

Alternativamente à hipótese de disseminação direta do WNV nas Américas por aves migratórias de longos voos, esta disseminação poderia acontecer em estágios, ou seja, as aves realizam pontos de parada em sua jornada do Norte para o Sul, de tal forma que venham gradualmente propagando os vírus em etapas, ou até disseminando o WNV para aves residentes nos locais de parada, fazendo com que o vírus seja disseminado gradativamente por pequenos deslocamentos entre as aves residentes de cada país, em vez de aves clinicamente infectadas viajando a distância total de migração, justificando então a detecção do WNV em anos sucessivos no decorrer de sua disseminação em direção ao Sul das Américas.

Os resultados da sorologia em equídeos, isto é, $2 \%$ de positivos por ELISA e PRNT ${ }_{90}$, suportam estas conclusões. Em outras palavras, o vírus provavelmente está sendo disseminado de Norte a Sul e está infectando cavalos, mas estes não estão indo a óbito. O primeiro ponto importante neste contexto é que as aves parecem estar disseminando o vírus para os cavalos no Brasil e talvez algumas aves fiquem doentes e morram, ou, alternativamente, as aves podem ser carreadoras do vírus sem estar clinicamente doentes durante o vôo, mas quando chegam ao seu destino, os mosquitos se alimentam desses pássaros, que estão estressados com 
a longa viagem, e o processo de alimentação dos mosquitos ativa o vírus pela transmissão salivar ativada (SAT- salivary activated transmission), assim, os mosquitos se infectam pelo vírus, que é então carreado aos equídeos. Os cavalos não morrem, possivelmente porque eles foram expostos anualmente ao SLEV e/ou outros Flavivirus locais, e portanto, mesmo que eles não tenham níveis de anticorpos no $\mathrm{PRNT}_{90}$, eles ainda teriam anticorpos apresentados no $\mathrm{PRNT}_{50}$.

Os resultados demonstram que o $\mathrm{PRNT}_{90}$ não se mostra tão eficaz quando os soros são coletados de aves saudáveis, em áreas onde não há associação com a doença. Isto também é observado, pois alguns dos soros de aves positivas por ELISA, obtiveram títulos mais elevados em termos de porcentagem de inibição, do que os soros de cavalo, que obtiveram anticorpos detectáveis no $\mathrm{PRNT}_{90}$, indicando claramente que estas aves devam ser positivas para WNV, mas quase certamente não estavam clinicamente doentes.

Além da preocupação com a saúde pública, existe também a grande preocupação econômica com o diagnóstico precoce da doença em equídeos, justificando então o início da aplicação de vacinas para o WNV em cavalos, ainda não utilizada no Brasil por conta da ausência do agente em território Nacional. Os cavalos que foram criados no Brasil, tem sido expostos a uma variedade de Flavivirus não letais, desenvolvendo assim, memória imunológica que os protege contra a exposição ocasional com o WNV. Como não existem casos clínicos de WNV no Brasil, este vírus é considerado uma doença exótica e por este motivo o Ministério da Agricultura e as políticas públicas de saúde, não permitem a importação ou produção de vacina para este tipo de doença. Se um animal é vacinado, tornase soropositivo e não pode ser considerado um caso sentinela. Sem vacinação, os casos soropositivos são a confirmação da circulação do vírus.

O custo-benefício da vacinação deve ser considerado. Na atual situação, a vacinação humana de WNV não é aplicável, pois não houve nenhum vírus detectado no país. A vacinação de aves selvagens não se aplica, principalmente devido à impossibilidade de lidar com estas. Já a vacinação de cavalos deve ser discutida por um foco econômico, pois o custobenefício de tratar os animais pode ser maior do que a liberação e lançamento da vacina (MARTINA; KORAKA; OSTERHAUS, 2010), principalmente se considerarmos que o Brasil tem o maior rebanho de cavalos da América do Sul (MINISTÉRIO DA AGRICULTURA, 2013).

Nosso trabalho mostra a possível circulação do WNV no Brasil, assim, a liberação do uso da vacina por livre demanda seria vantajoso para os proprietários de grandes rebanhos de equídeos valiosos, que não precisariam se preocupar com os altos custos do tratamento, ou 
possivelmente o óbito do animal. Além disso, a discussão sobre o uso de vacinas para WNV deve ser também expandida em termos ecológicos e epidemiológicos.

O Brasil, em comum com os outros países da América do Sul, parece ter estabelecido uma forma de co-existência do WNV pelo qual o vírus possa circular, embora a um nível baixo em termos de patogenicidade, sem causar quaisquer problemas reais. Este comentário é baseado nos resultados apresentados, demonstrando que o WNV está claramente presente na América do Sul e as aves, que são consideradas as carreadoras deste vírus, têm se movido entre as Américas.

Vindo de encontro aos resultados sorológicos apresentados e às hipóteses discutidas, os dois resultados positivos pela detecção molecular, nos levam a solidificar o pensamento de que o vírus iniciou seu processo de estabelecimento no país. O que chama a atenção é que a amostra da espécie Dendrocygna autumnalis com detecção positiva para o WNV, coletada no Maranhão em 2010 em importante ponto de parada de aves migratórias, é da mesma espécie, data e localização que a ave que obteve resultado sorológico positivo mais significativo para a presença de anticorpos para o WNV por ELISA. Entretanto, a positividade não foi confirmada por PRNT $_{90}$, pois provavelmente a ave apresentava quadro sub-clínico, apesar da alta porcentagem de inibição detectada.

Outro fato intrigante, foi quanto à amostra positiva na detecção molecular proveniente do Pantanal - MT coletada em 2012, da espécie Certhiaxis cinnamomeus, ave residente que realiza pequenos deslocamentos na região, e que foi capturada em local de grande concentração de aves que realizam deslocamentos e são provenientes de países vizinhos ao Brasil, como a Argentina, único local da América do Sul onde já houve o isolamento do WNV (MORALES et al., 2006).

A falta de provas para a evidência do WNV em aves no Brasil permanece enigmática, pois várias espécies migratórias foram avaliadas e aves soropositivas têm sido detectadas predominantemente nos últimos cinco anos em países vizinhos ao Brasil. Infecções experimentais em várias espécies de aves indicaram que os níveis de viremia permanecem elevados apenas em curta duração (máximo de 7 dias), fazendo com que a introdução de WNV por aves migrantes de longa distância seja um evento improvável (KOOPMANS et al., 2007) e corroborando com a tese de que o vírus esteja se disseminando por aves residentes ou migratórias de curta distância, explicando assim a propagação do vírus sequencialmente ao sul das Américas e não diretamente por aves migratórias provenientes da América do Norte.

Nosso trabalho analisou um grande número de amostras de aves migratórias provenientes de diferentes áreas de parada (stop-over areas), e de acordo com os resultados, 
acreditamos que a entrada do WNV no Brasil seja provavelmente por pássaros que realizam pontos de parada em sua viagem de norte a sul, de tal forma que as aves vêm carreando o vírus gradualmente em estágios, ao invés de aves clinicamente infectadas que viajam a distância total. Essa idéia é reforçada pela presença de anticorpos de WNV em amostras coletadas de equídeos apenas de 2009, mesmo ano em que outros estudos brasileiros detectaram sorologia positiva para WNV também em equinos (MELANDRI et al., 2012; PAUVOLID-CORRÊA et al., 2011). O trabalho de Diaz (ADRIÁN DIAZ et al., 2008) mostra claramente que a introdução de WNV na Argentina ocorreu inicialmente por aves, em janeiro de 2005. Esta informação reforça a teoria dos pontos de parada das aves migrantes e do contato de aves residentes, ou que façam pequenos deslocamentos, como no caso de aves que voam entre Brasil e Argentina, sendo que o contato das mesmas é bastante intenso.

Apesar de existir sistema de vigilância para doenças emergentes animais, não há casos clínicos de WNV em equídeos no Brasil. No entanto, o vírus pode estar presente em equídeos e aves, mas com infecção sub-clínica, devido à influência de outros Flavivirus que circulam no país. É provável que a epidemia de WNV na América do Sul se comporte de modo diferente do que observa-se na América do Norte.

É possível ainda que exista imunidade cruzada e que não esteja sendo detectada pelos testes PRNT $_{90}$ / ELISA, ou que exista um nível de resistência genética na América do Sul, que não está presente na América do Norte. Uma terceira possibilidade é que, embora as aves sejam capazes de carrear o vírus na América do Norte, onde foi originalmente introduzido a partir do Oriente, a maioria das aves migratórias que fazem a longa viagem para a América do Sul não estão carreando o vírus. Nos raros casos em que essas aves, que fazem a longa jornada estejam portando o vírus, quando estas aves chegam na América do Sul elas não necessariamente encontram mosquitos vetores apropriados e reservatórios adequados para permitir que o vírus esteja disponível para transmissão para os seres humanos, equídeos e outros animais.

Estudo prévio sobre a possibilidade de entrada do WNV no Brasil foi realizado pelo Ministério da Agricultura (ARAÚJO et al., 2003) e relatou alta positividade para diferentes arbovírus em aves, muitos dos quais foram caracterizados como Flavivirus. Os resultados indicam que as aves podem ser infectadas várias vezes com diferentes arbovírus.

Em nosso estudo, foram incluídas amostras de 2002 e 2006, que eram susceptíveis a serem negativas para WNV se considerarmos a dinâmica da epidemia nos Estados Unidos, o tempo de atraso para a chegada do vírus na América do Sul (KOMAR; CLARK, 2006) e o fato de que em estudo anterior, 1.439 aves migratórias e residentes a partir de 2002, 2003 e 
2004, apresentaram resultados negativos para WNV (ARAÚJO et al, 2003; ARAÚJO et al, 2004). Além disso, há falta de informação sobre casos clínicos de WNV em humanos e equídeos no Brasil, embora exista alguma vigilância de saúde pública e animal. Estes resultados reforçam a idéia de que WNV ainda não está estabelecido no país e os focos de estabelecimento da transmissão do vírus no Brasil ainda são desconhecidos.

Considerando o ciclo migratório de algumas aves e a existência de equídeos amplamente disseminados pelo território brasileiro, bem como a presença do ser humano, o potencial para o surgimento de surtos em animais e seres humanos no Brasil é preocupante, uma vez que o WNV pode se estabelecer no país e tornar-se endêmico em alguns Estados (FIGUEIREDO, 2007).

Há indícios de que o vírus esteja presente no Brasil, porém parece ainda não ocasionar casos significativos com apresentação de sintomas clínicos, ou o diagnóstico diferencial para o WNV ainda não seja aplicado de forma adequada em território nacional.

Em resumo, o WNV ainda não é um problema no Brasil, provavelmente porque há significante proteção imunológica devido à grande variedade de Flavivirus circulantes no país. Em segundo lugar, porque as aves migratórias que são infectadas pelo WNV são incapazes de realizar longas jornadas, sugerindo que a possibilidade de introdução do vírus ocorra via aves residentes sul-americanas. É perfeitamente possível que o WNV seja disseminado cada vez mais nos países da América do Sul e talvez torne-se um grande problema de saúde pública com grande impacto econômico em pouco tempo.

Por estes motivos, tão importante quanto as pesquisas emergenciais durante os surtos das doenças, são os estudos fora do contexto epidêmico. Desta forma, podem-se definir os principais nichos ecológicos do vírus do Oeste do Nilo e elaborar medidas preventivas, evitando a disseminação viral pelo país e o consequente acometimento da fauna e população brasileira. 


\section{CONCLUSÕES}

Até o presente momento, este é o estudo de maior amplitude realizado no Brasil, no qual analisamos no total 4.787 amostras de diferentes animais, biomas e regiões brasileiras.

Durante a elaboração deste trabalho pudemos evidenciar a detecção do WNV em duas amostras de aves silvestres, provenientes da região do Pantanal- MT e Reentrâncias Maranhenses - MA, pela detecção molecular por one-step real-time RT-PCR. Entretanto, apesar de diversas metodologias aplicadas e tentativas de isolamento e caracterização viral, não foi possível concretizar e definir as estirpes circulantes detectadas.

Do mesmo modo, foi possível realizar o perfil soro-epidemiológico pelo método de ELISA para detecção de anticorpos específicos para WNV em amostras de aves e equídeos de diferentes locais em território nacional. Confirmamos pela técnica de $\mathrm{PRNT}_{90}$ a presença de anticorpos específicos em 4 equídeos, também provenientes do Estado do Mato Grosso. Estes dados indicam o possível início da circulação do WNV em nosso país, demonstrando assim sua importância, e que a vigilância do vírus do Oeste do Nilo deve ser levada em consideração, tornando-se cada vez mais necessária no Brasil. 


\section{REFERÊNCIAS}

ADRIÁN DIAZ, L. et al. West Nile virus in birds, Argentina. Emerging Infectious Diseases, v. 14, n. 4, p. 689-691, 2008.

AGÊNCIA NACIONAL DE VIGILÂNCIA SANITÁRIA (ANVISA). Medidas sanitárias para o combate a Febre do oeste do Nilo, 2000. Disponível em: <http://www.anvisa.gov.br>. Acesso em: 5 jul. 2013.

ALESSI, C. Á. C. et al. American cutaneous leishmaniasis in the Pontal of Paranapanema SP, Brazil: ecological and entomological aspects. Revista do Instituto de Medicina Tropical de São Paulo, v. 51, n. 5, p. 277-282, 2009.

ANDERSON, J. F. et al. Isolation of West Nile virus from mosquitoes, crows, and a Cooper's hawk in Connecticut. Science (New York, N.Y.), v. 286, n. 5448, p. 2331-2333, 1999.

ANDERSON, J. F. et al. Prevalence of West Nile virus in tree canopy-inhabiting Culex pipiens and associated mosquitoes. The American Journal of Tropical Medicine and Hygiene, v. 71, n. 1, p. 112-119, 2004.

ANTAS, P. T. Z. Migration of Neartic shorebirds (Charadriidae and Scolopacidae) in Brazil flyways and their different seazonal use. Wader Study Group Bulletin, v. 39, p. 52-56, 1984.

ARAUJO, J. Detecção molecular de hantavírus pela técnica de real-time PCR em amostras de roedores silvestres coletadas na região do Vale do Ribeira no Estado de São Paulo. 2010. 110 f. Tese (Doutorado em Microbiologia) - Instituto de Ciências Biomédicas, Universidade de São Paulo, São Paulo, 2011.

ARAÚJO, F. A. A. et al. Primeiro Inquérito Sorológico em Aves Migratórias e Nativas do Parque Nacional da Lagoa do Peixe/RS para Detecção do Vírus do Nilo Ocidental. Boletim Eletrônico Epidemiológico, v. 1, p. 3-12, 2003.

ARAÚJO, F. A. A. et al. Segundo inquérito sorológico em aves migratórias e residentes do Parque Nacional da Lagoa do Peixe/RS para detecção do vírus da Febre do Nilo Ocidental e outros vírus. Boletim Eletrônico Epidemiológico, v. 5, p. 1-8, 2004.

ARAUJO, J. et al. Detection of hantaviruses in Brazilian rodents by SYBR-Green-based realtime RT-PCR. Archives of Virology, v. 156, n. 7, p. 1269-1274, 2011.

ARTSOB, H. et al. West Nile Virus in the New World: trends in the spread and proliferation of West Nile Virus in the Western Hemisphere. Zoonoses and Public Health, v. 56, n. 6-7, p. 357-369, 2009.

ARTSOB, H.; LINDSAY, R.; DREBOT, M. Biodiversity- related aspects of West Nile virus and its cycle in nature. Biodiversity, v. 7, p. 18-23, 2006.

\footnotetext{
*De acordo com:

ASSOCIAÇÃO BRASILEIRA DE NORMAS TÉCNICAS. NBR 6023: informação e documentação: referências: elaboração. Rio de Janeiro, 2002.
} 
ASNIS, D. S. West Nile virus infection in the United States: A review and update. Infections in Medicine, v. 19, n. 6, p. 266-278, 2002.

AUTORINO, G. L. et al. West Nile virus epidemic in horses, Tuscany region, Italy. Emerging Infectious Diseases, v. 8, n. 12, p. 1372-1378, 2002.

AZEVEDO JÚNIOR, S. M. et al. Recapturas e recuperações de aves migratórias no litoral de. Ararajuba, v. 9, n. 1, p. 33-42, 2001.

AZEVEDO-JÚNIOR, S. M. DE; LARRAZÁBAL, M. E. DE. Coroa do Avião. In: VALENTE, R. DE M. et al. (Eds.). Conservação de aves migratórias neárticas no Brasil. 1. ed. Belém: Conservação Internacional, 2011. p. 150-154.

BAQAR, S. et al. Vertical transmission of West Nile virus by Culex and Aedes species mosquitoes. The American Journal of Tropical Medicine and Hygiene, v. 48, n. 6, p. $757-$ $762,1993$.

BEASLEY, D. W. C. et al. Genome sequence and attenuating mutations in West Nile virus isolate from Mexico. Emerging Infectious Diseases, v. 10, n. 12, p. 2221-2224, 2004.

BEISSINGER, S. R.; OSBORNE, D. R. Effects of urbanization on avian community organization. Condor, v. 84, n. 1, p. 75-83, 1982.

BLITVICH, B. J. et al. Epitope-blocking enzyme-linked immunosorbent assays for the detection of serum antibodies to west nile virus in multiple avian species. Journal of Clinical Microbiology, v. 41, n. 3, p. 1041-1047, 2003.

BLITVICH, B. J. et al. Serologic evidence of West Nile virus infection in horses, Coahuila State, Mexico. Emerging Infectious Diseases, v. 9, n. 7, p. 853-856, 2003.

BODE, A. V et al. West Nile virus disease: a descriptive study of 228 patients hospitalized in a 4-county region of Colorado in 2003. Clinical Infectious Diseases: An Official Publication of the Infectious Diseases Society of America, v. 42, n. 9, p. 1234-1240, 2006.

BOSCH, I. et al. West Nile virus, Venezuela. Emerging Infectious Diseases, v. 13, n. 4, p. 651-653, 2007.

BOWEN, R. A.; NEMETH, N. M. Experimental infections with West Nile virus. Current Opinion in Infectious Diseases, v. 20, n. 3, p. 293-297, 2007.

BRINTON, M. A. Replication of flaviviruses. In: SCHLESINGER, S.; SCHLESINGER, M. (Eds.). The Togaviridae and Flaviviridae. New York: Plenun press, 1986. p. 327-374.

BROOKS, G. F.; BUTEL, J. S.; MORSE, A. S. Doenças virais transmitidas por artrópodes \& roedores. In: JAWETZ, E.; MELNICK, J.; ADELBERG, A.E. (Ed.). Microbiologia médica. Rio de Janeiro: Guanabara Koogan, 2000. p. 375-393.

BUNNING, M. L. et al. Experimental infection of horses with West Nile virus. Emerging Infectious Diseases, v. 8, n. 4, p. 380-386, 2002. 
CENTERS FOR DISEASE CONTROL AND PREVENTION (CDC). Outbreak of West Nile-like viral encephalitis, 1999. Disponível em: 〈http://www.cdc.gov>. Acesso em: 10 fev. 2013.

CENTERS FOR DISEASE CONTROL AND PREVENTION (CDC). West Nile Virus: What You Need To Know. Disponível em: <http://www.cdc.gov/westnile >. Acesso em: 23 jul. 2013.

CENTERS FOR DISEASE CONTROL AND PREVENTION (CDC). 2012 West Nile virus update: December 11. Disponível em: <http://www.cdc.gov/westnile >. Acesso em: 25 jan. 2013.

CHARREL, R. N. et al. Evolutionary relationship between Old World West Nile virus strains. Evidence for viral gene flow between Africa, the Middle East, and Europe. Virology, v. 315, n. 2, p. 381-388, 2003.

CHEVALIER, V. et al. Epidemiological processes involved in the emergence of vector-borne diseases: West Nile fever, Rift Valley fever, Japanese encephalitis and Crimean-Congo haemorrhagic fever. Revue Scientifique et Technique (International Office of Epizootics), v. 23, n. 2, p. 535-555, 2004.

CHU, J. J. H.; NG, M. L. The mechanism of cell death during West Nile virus infection is dependent on initial infectious dose. Journal of General Virology, v. 84, n. 12, p. 33053314, 2003.

CORDELLIER, R.; DEGALLIER, N. Environment, arbovirus transmission and control of epidemics. Cadernos de Saúde Pública, v. 8, n. 3, p. 249-253, 1992.

DARWISH, M. A.; IBRAHIM, A. H. Prevalence of antibodies to arboviruses in Egypt. Results of a serologic survey among 1,113 university students. The American Journal of Tropical Medicine and Hygiene, v. 24, n. 6, p. 981-985, 1975.

DAUPHIN, G.; ZIENTARA, S. West Nile virus: recent trends in diagnosis and vaccine development. Vaccine, v. 25, n. 30, p. 5563-5576, 2007.

DE FILETTE, M. et al. Recent progress in West Nile virus diagnosis and vaccination. Veterinary Research, v. 43, n. 1, p. 16, 2012.

DELAWARE, University. College of Marine and Earth Studies, 2007. Disponível em: <http://www.ocean.udel.edu>. Acesso em: 23 jul. 2013

DESJARDINS, P.; MORAIS, R. Sequence and gene organization of the chicken mitochondrial genome. A novel gene order in higher vertebrates. Journal of Molecular Biology, v. 212, n. 4, p. 599-634,1990.

DOMINGO, C. et al. Molecular diagnosis of flaviviruses. Future Virology, v. 6, n. 9, p. 1059-1074, 2011.

DRIDI, M. et al. Experimental infection of Carrion crows (Corvus corone) with two European West Nile virus (WNV) strains. Veterinary Microbiology, v. 165, n. 1-2, p. 160-166, 2013. 
ELTON, C. S.; MILLER, R. S. The Ecological Survey of Animal Communities: With a Practical System of Classifying Habitats by Structural Characters. Journal of Ecology, v. 42, n. 2, p. 460-496, 1954.

EQUIPE DE CAMPO. Fotos retiradas nas expedições científicas pela equipe de campo do Laboratório de Virologia Clínica e Molecular do ICB II - USP. Ometto, T.; Araujo, J.; Thomazelli, L.M.; Hurtado, R.F.; Seixas, M.M.M.; Durigon, E.L., Eds. São Paulo, 2013.

ERNEK, E. et al. Arboviruses in birds captured in Slovakia. Journal of Hygiene, Epidemiology, Microbiology, and Immunology, v. 21, n. 3, p. 353-359, 1977.

ESPY, M. J. et al. Real-time PCR in clinical microbiology: applications for routine laboratory testing. Clinical Microbiology Reviews, v. 19, n. 1, p. 165-256, 2006.

ESTRADA-FRANCO, J. G. et al. West Nile virus in Mexico: evidence of widespread circulation since July 2002. Emerging Infectious Diseases, v. 9, n. 12, p. 1604-1607, 2003.

FIGUEIREDO, L. T. M. Emergent arboviruses in Brazil. Revista da Sociedade Brasileira de Medicina Tropical, v. 40, n. 2, p. 224-229, 2007.

FLORES, E. F.; WEIBLEN, R. O vírus do Nilo Ocidental. Ciência Rural, v. 39, n. 2, p. 604$612,2009$.

FORATTINI, O. P. Culicidologia médica. 2. ed. São Paulo: EDUSP, 2002. 864 p.

FULOP, L. et al. Rapid identification of flaviviruses based on conserved NS5 gene sequences. Journal of Virological Methods, v. 44, n. 2-3, p. 179-188,1993.

GAIDET, N. et al. Avian influenza viruses in water birds, Africa. Emerging Infectious Diseases, v. 13, n. 4, p. 626-629, 2007.

GERALDI, M. P. Pesquisa sentinela da introdução do vírus do Oeste do Nilo no Brasil pela análise de doadores de sangue do Amazonas e Mato Grosso do Sul. 2012. $71 \mathrm{f}$. Dissertação (Mestrado em Ciências) - Instituto de Medicina Tropical, Universidade de São Paulo, São Paulo, 2012.

GODDARD, L. B. et al. Vertical transmission of West Nile Virus by three California Culex (Diptera: Culicidae) species. Journal of Medical Entomology, v. 40, n. 6, p. 743-746, 2003.

GOLDBLUM, N. et al. The natural history of West Nile Fever. I. Clinical observations during an epidemic in Israel. American Journal of Hygiene, v. 64, n. 3, p. 259-269, 1956.

GOVERNO DO ESTADO DE PERNAMBUCO. Meio Ambiente. Disponível em: <http://www.noronha.pe.gov.br>. Acesso em: 6 ago. 2013

GOVERNO DO ESTADO DO MATO GROSSO. Geografia. Disponível em: <http://www.mt.gov.br>. Acesso em: 22 jul. 2013. 
GUBLER, D. J. et al. Climate variability and change in the United States: potential impacts on vector- and rodent-borne diseases. Environmental Health Perspectives, v. 109 Suppl , p. 223-233, 2001.

GUBLER, D. J. The continuing spread of West Nile virus in the western hemisphere. Clinical Infectious Diseases: An Official Publication of the Infectious Diseases Society of America, v. 45, n. 8, p. 1039-1046, 2007.

HAYES, E. B. et al. Epidemiology and transmission dynamics of West Nile virus disease. Emerging Infectious Diseases, v. 11, n. 8, p. 1167-1173, 2005.

HENRIQUES, D. A. Caracterização molecular de arbovírus isolados da fauna diptera nematocera do estado de Rondônia (Amazônia Ocidental Brasileira). 2008. 128 f. Tese (Doutorado em Ciências (Microbiologia) - Instituto de Ciências Biomédicas, Universidade de São Paulo, São Paulo, 2008.

HUBÁLEK, Z. An annotated checklist of pathogenic microorganisms associated with migratory birds. Journal of Wildlife Diseases, v. 40, n. 4, p. 639-659, 2004.

HUBÁLEK, Z.; HALOUZKA, J. West Nile fever--a reemerging mosquito-borne viral disease in Europe. Emerging Infectious Diseases, v. 5, n. 5, p. 643-650, 1999.

HURLBUT, H. S. et al. A study of the ecology of West Nile virus in Egypt. The American Journal of Tropical Medicine and Hygiene, v. 5, n. 4, p. 579-620, 1956.

INSTITUTO BRASILEIRO DO MEIO AMBIENTE E DOS RECURSOS NATURAIS RENOVÁVEIS - IBAMA. Centro de Triagem de Animais Silvestres. Disponível em: <http://www.ibama.gov.br/areas-tematicas-go/centro-de-triagem-de-animais-silvestres>.

Acesso em: 20 nov. 2013

INSTITUTO CHICO MENDES DE CONSERVAÇÃO DA BIODIVERSIDADE - ICMBIO. Biodiversidade - Fauna brasileirsa. Disponível em: <http://www.icmbio.gov.br/portal/biodiversidade/fauna-brasileira/lista-especies/471-rabo-depalha-de-bico-vermelho>. Acesso em: 10 nov. 2013

INNIS, B. L. et al. An enzyme-linked immunosorbent assay to characterize dengue infections where dengue and Japanese encephalitis co-circulate. The American Journal of Tropical Medicine and Hygiene, v. 40, n. 4, p. 418-427, 1989.

JIBIN, Z. et al. Production and characterization of monoclonal antibodies to nucleoprotein of Marburg virus. Hybridoma (2005), v. 27, n. 6, p. 423-429, 2008.

JOHNSON, B. W. et al. Evaluation of chimeric Japanese encephalitis and dengue viruses for use in diagnostic plaque reduction neutralization tests. Clinical and Vaccine Immunology: CVI, v. 16, n. 7, p. 1052-1059, 2009.

JOKIMAKI, J. et al. Biogeographical comparison of winter bird assemblages in urban environments in Finland. Journal of Biogeography, v. 23, n. 3, p. 379-386, 1996. 
JONES, K. E. et al. Global trends in emerging infectious diseases. Nature, v. 451, n. 7181, p. 990-993, 2008.

KARABATSOS, N. International catalogue of arboviruses, including certain other viruses of vertebrates. 3 rd ed. San Antonio, Texas: American Society of Tropical Medicine and Hygiene, 1985. $1041 \mathrm{p}$.

KEESING, F. et al. Impacts of biodiversity on the emergence and transmission of infectious diseases. Nature, v. 468, n. 7324, p. 647-652, 2010.

KLENK, K. et al. Alligators as West Nile virus amplifiers. Emerging Infectious Diseases, v. 10, n. 12, p. 2150-2155, 2004.

KOMAR, N. et al. Experimental infection of North American birds with the New York 1999 strain of West Nile virus. Emerging Infectious Diseases, v. 9, n. 3, p. 311-322, 2003.

KOMAR, N.; CLARK, G. G. West Nile virus activity in Latin America and the Caribbean. Revista Panamericana de Salud Pública = Pan American Journal of Public Health, v. 19, n. 2, p. 112-117, 2006.

KOOPMANS, M. et al. West Nile Virus in Europe: waiting for the start of the epidemic? In: TAKKEN, W.; KNOLS, B. G. J. (Ed.). Emerging pests and vector-borne diseases in Europe. Wageningen: Wageningen Academic Publishers, 2007. p. 123-151

KRAMER, L. D.; LI, J.; SHI, P.-Y. West Nile virus. Lancet Neurology, v. 6, n. 2, p. 171$181,2007$.

KUBISTA, M. et al. The real-time polymerase chain reaction. Molecular Aspects of Medicine, v. 27, n. 2-3, p. 95-125, 2006.

KUNO, G. Serodiagnosis of flaviviral infections and vaccinations in humans. Advances in Virus Research, v. 61, p. 3-65, 2003.

KUNO, G.; GUBLER, D. J.; OLIVER, A. Use of "original antigenic sin" theory to determine the serotypes of previous dengue infections. Transactions of the Royal Society of Tropical Medicine and Hygiene, v. 87, n. 1, p. 103-105, 1993.

LANCIOTTI, R. S. et al. Origin of the West Nile virus responsible for an outbreak of encephalitis in the northeastern United States. Science (New York, N.Y.), v. 286, n. 5448, p. 2333-2337, 1999.

LANCIOTTI, R. S. et al. Rapid detection of west nile virus from human clinical specimens, field-collected mosquitoes, and avian samples by a TaqMan reverse transcriptase-PCR assay. Journal of Clinical Microbiology, v. 38, n. 11, p. 4066-4071, 2000.

LANCIOTTI, R. S. et al. Complete genome sequences and phylogenetic analysis of West Nile virus strains isolated from the United States, Europe, and the Middle East. Virology, v. 298, n. 1, p. 96-105, 2002. 
LANCIOTTI, R. S. Molecular amplification assays for the detection of flaviviruses. Advances in Virus Research, v. 61, p. 67-99, 2003.

LEFRANÇOIS, T. et al. West Nile virus surveillance, Guadeloupe, 2003-2004. Emerging Infectious Diseases, v. 11, n. 7, p. 1100-1103, 2005.

LEVI, J. E. et al. Investigação molecular da presença do vírus do Oeste do Nilo em doadores de sangue e pacientes de três regiões brasileiras. Revista Brasileira de Hematologia e Hemoterapia, v. 33, n. 2, p. 399, 2011.

LINDENBACH, B. D.; RICE, C. M. Molecular biology of flaviviruses. Advances in Virus Research, v. 59, p. 23-61, 2003.

LIU, L. et al. Flavivirus RNA cap methyltransferase: structure, function, and inhibition. Frontiers in Biology, v. 5, n. 4, p. 286-303, 2010.

LOPES, R. J. Presídio Viral. Revista Super Interessante, p. 22-23, 2004.

LOROÑO-PINO, M. A. et al. Serologic evidence of West Nile virus infection in horses, Yucatan State, Mexico. Emerging Infectious Diseases, v. 9, n. 7, p. 857-859, 2003.

MAEDA, A.; MAEDA, J. Review of diagnostic plaque reduction neutralization tests for flavivirus infection. Veterinary Journal (London, England: 1997), v. 195, n. 1, p. 33-40, 2013.

MARR, J. S.; CALISHER, C. H. Alexander the Great and West Nile virus encephalitis. Emerging Infectious Diseases, v. 9, n. 12, p. 1599-1603, 2003.

MARTINA, B. E. E.; KORAKA, P.; OSTERHAUS, A. D. M. E. West Nile Virus: is a vaccine needed? Current Opinion in Investigational Drugs (London, England: 2000), v. 11, n. 2, p. 139-146, 2010.

MATTAR, S. et al. West Nile virus antibodies in Colombian horses. Emerging Infectious Diseases, v. 11, n. 9, p. 1497-1498, 2005.

MCINTOSH, B. M. et al. Epidemics of West Nile and Sindbis viruses in South Africa with Culex (Culex) univittatus Theobald as vector. South African Journal of Science, v. 72, n. 10, p. 295-300, 1976.

MCINTOSH, B. M.; DICKINSON, D. B.; MCGILLIVRAY, G. M. Ecological studies on Sindbis and West Nile viruses in South Africa. V. The response of birds to inoculation of virus. The South African Journal of Medical Sciences, v. 34, n. 3, p. 77-82, 1969.

MELANDRI, V. et al. Serological detection of West Nile virus in horses and chicken from Pantanal, Brazil. Memórias do Instituto Oswaldo Cruz, v. 107, n. 8, p. 1073-1075, 2012.

MENDONÇA, L. B.; ANJOS, L. DOS. Beija-flores (Aves, Trochilidae ) e seus recursos florais em uma área urbana do Sul do Brasil. Revista Brasileira de Zoologia, v. 22, n. 1, p. 51-59, 2005. 
MERCK. Doenças infecciosas. In: BEERS, M. H.; BERKOW, R. (Ed.). Manual Merck. 17. ed. São Paulo: Editora Roca, 2001. p. 1071-1087.

MINISTÉRIO DA AGRICULTURA. Equídeos. Disponível em: <http://www.agricultura.gov.br/animal/especies/equideos>. Acesso em: 20 maio. 2013.

MONACO, F. et al. Re-emergence of West Nile virus in Italy. Zoonoses and Public Health, v. 57, n. 7-8, p. 476-486, 2010.

MONEZI, T. A. Caracterização dos tipos genômicos de parvovírus caninos isolados em diferentes regiões do Brasil no período de 1989 a 1996. 2000. 113 f. Dissertação (Mestrado em Ciências - Microbiologia) - Intituto de Ciências Biomédicas, Universidade de São Paulo, São Paulo, 2000.

MONINI, M. et al. West nile virus: characteristics of an african virus adapting to the third millennium world. The Open Virology Journal, v. 4, p. 42-51, 2010.

MONTES, J. Fauna de Culicidae da Serra da Cantareira, São Paulo, Brasil. Revista de Saúde Pública, v. 39, n. 4, p. 578-584, 2005.

MORALES, M. A. et al. West Nile virus isolation from equines in Argentina, 2006. Emerging Infectious Diseases, v. 12, n. 10, p. 1559-1561, 2006.

MORRISON, R. I. G.; ROSS, R. K. Atlas of Nearctic shorebirds on the coast of South America. Canadian Wildlife Service Special Publication, v. 2, p. 128, 1989.

MOUREAU, G. et al. A real-time RT-PCR method for the universal detection and identification of flaviviruses. Vector Borne and Zoonotic Diseases (Larchmont, N.Y.), v. 7, n. 4, p. 467-477, 2007.

NATHANSON N. Pathogenisis. In: MONATH, T. P. (Ed.). St Louis encephalitis. Washington, Dc: Alpha, 1980. p. 201-236.

NATIONAL GEOGRAPHIC - NATGEO. National Geographic Maps the classic collection. Disponível em: <http://www.ngmapcollection.com>. Acesso em: 17 jul. 2013

NAZE, F. et al. Simultaneous detection and quantitation of Chikungunya, dengue and West Nile viruses by multiplex RT-PCR assays and dengue virus typing using high resolution melting. Journal of Virological Methods, v. 162, n. 1-2, p. 1-7, 2009.

NG, T. et al. Equine vaccine for West Nile virus. Developments in Biologicals, v. 114, p. 221-227, 2003.

NIR, Y. et al. Isolation of arboviruses from wild birds in Israel. American Journal of Epidemiology, v. 86, n. 2, p. 372-378, 1967.

NUNES, A.; TOMAS, W. Aves migratórias e nômades ocorrentes no Pantanal. Revista Brasileira de Pesquisa Agropecuária, p. 123, 2008. 
OLIVEIRA, O. A. Geografia de Rondônia - espaço e produção. Porto Velho: Dinâmica, 1980. p. 160.

OMETTO, T. et al. West Nile virus surveillance, Brazil, 2008-2010. Transactions of the Royal Society of Tropical Medicine and Hygiene, v. 107, n. 11, p. 723-730, 2013.

ORICO, L. D. Pesquisa de infecções por Flavivirus sp. em aves silvestres provenientes das áreas verdes do município de São Paulo. 2013. 104 f. Dissertação (Mestrado em Ciências) - Faculdade de Saúde Pública, Universidade de São Paulo, São Paulo, 2013.

OSTLUND, E. N. et al. Equine West Nile encephalitis, United States. Emerging Infectious Diseases, v. 7, n. 4, p. 665-669, 2001.

OSTLUND, E. N.; ANDRESEN, J. E.; ANDRESEN, M. West Nile encephalitis. The Veterinary Clinics of North America. Equine Practice, v. 16, n. 3, p. 427-441, 2000.

PAI, A. et al. Performance characteristics of the food and drug administration-licensed roche cobas taqscreen West Nile virus assay. Transfusion, v. 48, n. 10, p. 2184-2189, 2008.

PAUVOLID-CORREAA, A. et al. Serologic evidence of the recent circulation of Saint Louis encephalitis virus and high prevalence of equine encephalitis viruses in horses in the Nhecolândia sub-region in South Pantanal, Central-West Brazil. Memórias do Instituto Oswaldo Cruz, v. 105, n. 6, p. 829-833, 2010.

PAUVOLID-CORREAA, A. et al. Neutralising antibodies for West Nile virus in horses from Brazilian Pantanal. Memórias do Instituto Oswaldo Cruz, v. 106, n. 4, p. 467-474, 2011.

PEIRIS, J. S. M.; AMERASINGHE, F. P. West Nile fever. In: BERAN, G. W.; STEELE, J. H. (Ed.). Handbook of Zoonoses. 2nd ed. Boca Raton: CRC Press, 1994. p. 139-148.

PETERSEN, L. R.; HAYES, E. B. West Nile virus in the Americas. The Medical Clinics of North America, v. 92, n. 6, p. 1307-1322, 2008.

PINTO, J. et al. Climate change and animal diseases in South America. Revue Scientifique et Technique (International Office of Epizootics), v. 27, n. 2, p. 599-613, 2008.

POGODINA, V. V et al. Study on West Nile virus persistence in monkeys. Archives of Virology, v. 75, n. 1-2, p. 71-86, 1983.

REED, K. D. et al. Birds, migration and emerging zoonoses: west nile virus, lyme disease, influenza A and enteropathogens. Clinical Medicine \& Research, v. 1, n. 1, p. 5-12, 2003.

RICE, C. M. et al. Nucleotide sequence of yellow fever virus: Implications for flavivirus gene expression and evolution. Science, v. 229, p. 726-735, 1985.

RICHMOND, J.; MCKINNEY, R. Biosafety in Microbiological and Biomedical Laboratories, Fourth Edition. US Government Printing Office, 1999.

ROBINSON, W. H. Handbook of urban insects and arachnids. Cambridge: Cambridge University Press, 2005. 456 p. 
RODRIGUES, R. C. et al. Temporal variations of body mass and plumage in Arenaria interpres (Aves: Scolopacidae) along the Brazilian coast. Zoologia (Curitiba, Impresso), v. 26, n. 3, p. 386-390, 2009.

ROSA, J. F. S. T. DA et al. Arboviruses isolated in the Evandro Chagas Institute, including some described for the first time in the Brazilian Arnazon region, their known hosts, and their pathology for man. In: ROSA, A. P. A. T. DA; VASCONCELOS, P. F. C.; ROSA, J. F. S. T. DA (Ed.). An overview of arbovirology in Brazil and neighbouring countries. Belém: Instituto Evandro Chagas, 1998. p. 31.

SABATTINI, M. S.; AVILE'S, G.; MONATH, T. P. Historical, epidemiological and ecological aspects of arboviruses in Argentina: Togaviridae, Alphavirus. . In: TRAVASSOS DA ROSA, A. P. A.; VASCONCELOS, P. F. C.; TRAVASSOS DA ROSA, J. F. S. (Eds.). An Overview of Arbovirology in Brazil and Neighboring Countries. Belém: Instituto Evandro Chagas, 1998. p. 135-153.

SAMBROOK, J.; FRITSCH, E. F.; MANIATIS, T. Molecular Cloning. 2nd ed. New York: Cold Spring Harbor Press, 1989.

SANGER, F.; NICKLEN, S.; COULSON, A. R. DNA sequencing with chain-terminating inhibitors. Proceedings of the National Academy of Sciences of the United States of America, v. 74, n. 12, p. 5463-5467, 1977.

SCHMITTGEN, T. D.; LIVAK, K. J. Analyzing real-time PCR data by the comparative C(T) method. Nature Protocols, v. 3, n. 6, p. 1101-1108, 2008.

SHORTRIDGE, K. F.; BURROWS, D. Prevention of entry of avian influenza and paramyxoviruses into an ornithological collection. The Veterinary Record, v. 140, n. 14, p. 373-374, 1997.

SICK, H. Migrações de aves no Brasil. Brasil Florestal, v. 39, p. 7-10, 1979.

SICK, H. Migração de Aves na América do Sul Continental. Ministério da Agricultura, Instituto Brasileiro de Desenvolvimento Florestal. Brasília: Ministério da Agricultura, 1983.

SICK, H. Espécies visitantes, migrações. In: introdução. 3. ed. Brasília: Universidade de Brasília, 1997. p. 129-131.

SICK, H. Ornitologia brasileira. Rio de Janeiro: Editora Nova Fronteira, 2001.

SIMONETTI, J. P. Especial doenças emergentes. Disponível em: <http://portal.fiocruz.br>. Acesso em: 11 nov. 2013.

SMITHBURN, K. et al. A neurotropic virus isolated from the blood of a native of Uganda. American Journal of Tropical Medicine, v. 20, p. 471-492, 1940.

SOUTHAM, C. M.; MOORE, A. E. Induced virus infections in man by the Egypt isolates of West Nile virus. The American Journal of Tropical Medicine and Hygiene, v. 3, n. 1, p. 19-50, 1954. 
SPICER, G. S.; DUNIPACE, L. Molecular phylogeny of songbirds (Passeriformes) inferred from mitochondrial 16S ribosomal RNA gene sequences. Molecular Phylogenetics and Evolution, v. 30, n. 2, p. 325-335, 2004.

STANIER, R.; DOUDOROFF, M.; ADELBERG, E. Os vírus. In: Mundo dos micróbios. São Paulo: Edgard Blucher, 1969. p. 184.

STEELE, K. E. et al. Pathology of fatal West Nile virus infections in native and exotic birds during the 1999 outbreak in New York City, New York. Veterinary Pathology, v. 37, n. 3, p. 208-224, 2000.

STEINMAN, A. et al. West Nile virus infection in crocodiles. Emerging Infectious Diseases, v. 9, n. 7, p. 887-889, 2003.

STRAMER, S. L. et al. West Nile virus among blood donors in the United States, 2003 and 2004. The New England Journal of Medicine, v. 353, n. 5, p. 451-459, 2005.

THOMAZELLI, L. et al. Molecular surveillance of the Newcastle disease virus in domestic and wild birds on the North Eastern Coast and Amazon biome of Brazil. Revista Brasileira de Ciência Avícola, v. 14, n. 1, p. 1-7, 2012.

TRABULSI, L.; ALTERTHUM, F. Doenças virais transmitidas por artrópodes e roedores. In: Microbiologia. 4. ed. São Paulo: Atheneu, 2005. p. 671-682.

TRENT, D. W.; QURESHI, A. A. Structural and nonstructural proteins of Saint Louis encephalitis virus. Journal of Virology, v. 7, n. 3, p. 379-388, 1971.

TROCK, S. C. et al. West Nile virus outbreak among horses in New York State, 1999 and 2000. Emerging Infectious Diseases, v. 7, n. 4, p. 745-747, 2001.

UNITED STATES GEOLOGICAL SURVEY -USGS. Species Affected by West Nile Virus. 2007. Disponível em: <http://www.nwhc.usgs.gov/disease_information/west_nile_virus>. Acesso em: 12 nov. 2013.

UNITED STATES INFORMATION - USINFO. International Information Programs. U.S. Department of State, 2007. Disponível em: 〈http://www.usinfo.state.gov>. Acesso em: 21 jul. 2013

URBINATTI, P. R.; SENDACZ, S.; NATAL, D. Imaturos de mosquitos (Diptera: Culicidae) em parque de área metropolitana aberto à visitação pública. Revista de Saúde Pública, v. 35, n. 5, p. 461-466, 2001.

VACCINENEWSDAILY. West Nile virus spreading quickly in the U.S. Disponível em: <http://vaccinenewsdaily.com>. Acesso em: 27 jan. 2013

VASCONCELOS, P. F. et al. Epidemic of jungle yellow fever in Brazil, 2000: implications of climatic alterations in disease spread. Journal of Medical Virology, v. 65, n. 3, p. 598604, 2001. 
WEIDMANN, M. et al. Rapid detection of human pathogenic orthobunyaviruses. Journal of Clinical Microbiology, v. 41, n. 7, p. 3299-3305, 2003.

WHATELY, M. et al. Parques urbanos municipais de São Paulo: Subsídios para a gestão. São Paulo: Instituto Socioambiental, 2008. p. 119.

WIDMAN, D. G.; FROLOV, I.; MASON, P. W. Third-generation flavivirus vaccines based on single-cycle, encapsidation-defective viruses. Advances in Virus Research, v. 72, p. 77 $126,2008$.

WORLD ORGANIZATION FOR ANIMAL HEALTH - OIE. Manual of Diagnostic Tests and Vaccines for Terrestrial Animals. 5th edition, 2004. Disponível em: <http://www.oie.int>. Acesso em: 15 jul. 2013

ZIPPER, H. et al. Investigations on DNA intercalation and surface binding by SYBR Green I, its structure determination and methodological implications. Nucleic Acids Research, v. 32, n. 12, p. 103, 2004. 


\section{APÊNDICES}

APÊNDICE A - Tabela de amostras coletadas

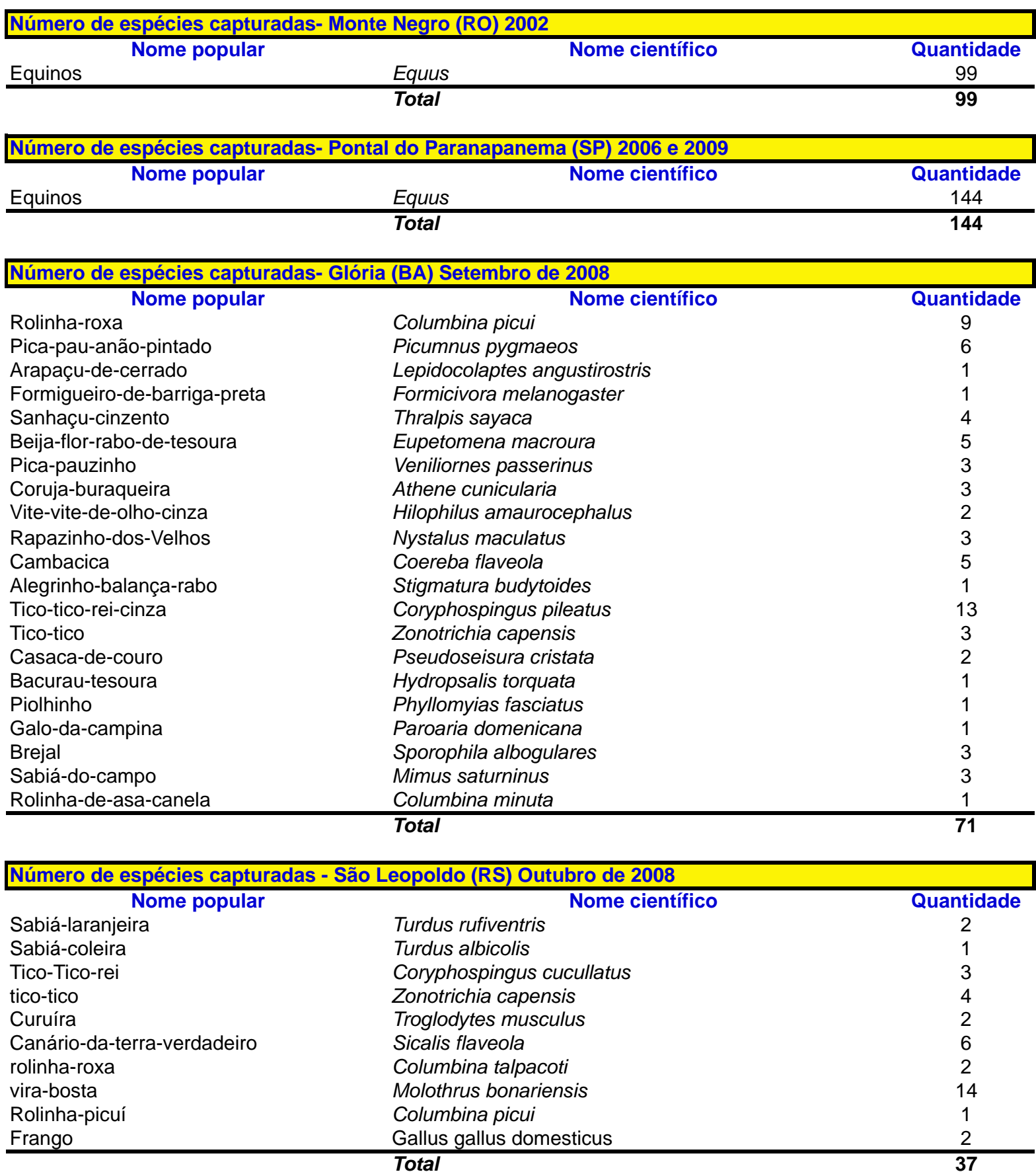




\begin{tabular}{llc}
\hline \multicolumn{2}{c}{ Número de espécies capturadas- Pinhal (RS) Outubro de 2008 } & \multicolumn{1}{c}{ Nome científico } \\
\hline \multicolumn{1}{c}{ Nome popular } & Quffinus puffinus & 23 \\
bobo-pequeno & Spheniscus magellanicus \\
pingüin-de-magalhães & Procellaria aequinoctialis & 11 \\
pardela-preta & Calidris alba & 1 \\
maçarico-branco & Thalassarche chlororhynchos & 1 \\
albatroz-de-nariz-amarelo & Tyto alba & 2 \\
coruja-da-igreja & Geotrygon montana & 1 \\
pariri & Puffinus gravis & 1 \\
bobo-grande-de-sobre-branco & Macronectes giganteus & 1 \\
petrel-gigante & Phalacrocorax brasilianus & 1 \\
Biguá & Pitangus sulphuratus & 1 \\
bem-te-vi & Total & 1 \\
\hline
\end{tabular}

Número de espécies capturadas- Coroa do Avião (PE) Outubro de 2008

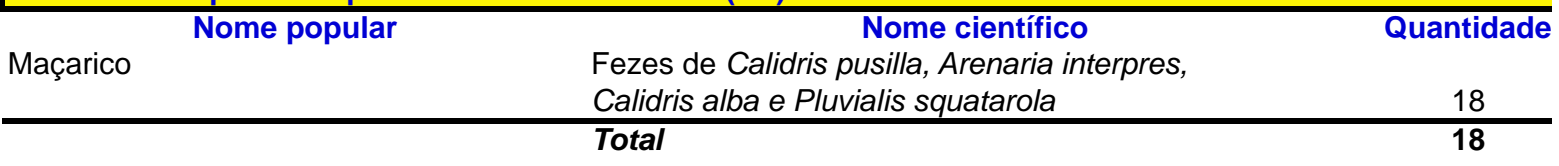

Número de espécies capturadas- Tupandi (RS) Novembro de 2008

\begin{tabular}{llc}
\hline \multicolumn{1}{c}{ Nome popular } & \multicolumn{1}{c}{ Nome científico } & Quantidade \\
Tico-Tico-rei & Coryphospingus cucullatus & 4 \\
Pardal & Passer domesticus & 6 \\
Curuíra & Troglodytes musculus & 3 \\
Tico-Tico-rei & Zonotrichia capensis & 3 \\
Canário-da-terra-verdadeiro & Sicalis flaveola & 6 \\
Sabiá-laranjeira & Turdus rufiventris & 1 \\
Sabiá-poca & Turdus amaurochalinus & 1 \\
Rolinha-roxa & Columbina talpacoti & 3 \\
\hline
\end{tabular}

Número de espécies capturadas- Ilha de Canelas (PA) Novembro de 2008

Nome popular Nome científico

Maçarico-rasteiro

Trinta-réis

Bate-bunda

Figuinha-do-mangue

Vira-pedras

Maçarico-branco

Maçarico-de-perna-amarela

Maçarico

andorinha-de-bando

Pintassilgo

Garça-morena

Batuíra-de-bando
Calidris pusilla

Sterna nilotica

Actitis macularius

Cornirostrum bicolor

Arenaria interpres

Calidris alba

| Tringa melanoleuca

Liminodromus griseus

Hirundo rustica

Fringillidae

Egretta caerula

Charadrius semipalmatus
Nome científico

Quantidade

5

1

31

9

22

2

1

9

4

1

1

$\frac{1}{87}$ 
Número de espécies capturadas- Pinhal (RS) Novembro e Dezembro de 2008

\section{Nome popular}

pingüin-de-magalhães

albatroz-de-nariz-amarelo

bobo-grande-de-sobre-branco

Maçarico-branco

bobo-pequeno

piru-piru

Pomba do Cabo

pardela-preta

Gaivotão

tico-tico

Pombo domestico

albatroz-de-sombrancelha

sem nome

bobo-grande
Nome científico

Spheniscus magellanicus

Thalassarche chlororhynchos

Puffinus gravis

Calidris alba

Puffinus puffinus

Haematopus palliatus

Daption capense

Procellaria aequinoctialis

Larus dominicanus

procellaria conspciliatta

Columba livea

Thalassarche melanophris

Puffinus sp.

Calonectris diomedea
Quantidade

16

6

4

1

7

1

4

1

1

1

1

53

Número de espécies capturadas- Feliz (RS) Dezembro de 2008

\section{Nome popular}

Sabiá-laranjeira

Sabiá-coleira

Martim-pescador-pequeno

Pula-pula

Curuíra

Tico-Tico-rei

Arapaçu-grande

Tangará

tico-tico

Vira-bosta

Tie preto

Chupa-dente

Trinca-ferro-verdadeiro

Cambacica

Choca-da-mata

Pi-puí

Pica-pau-anão-de-coleira

João-Teneném

Patinho

Pica-pau-anão-de-coleira

\section{Nome científico}

Turdus rufiventris

Turdus albicolis

Chloroceryle americana

Basileuterus culicivorus

Troglodytes musculus

Coryphospingus cucullatus

Dendrocolaptes platyrostris

Chiroxithia caudata

Zonotrichia capensis

Molothrus bonariensis

Tchythonus coronatus

Conophaga lineata

Saltator simis

Coereba flaveola

Thamnophilus caerulescens

Synallaxis cinerascens

Picumnus temminckii

Synallaxis spixi

Platyrinchus mystaceus

Picumnus temminckii

Total

Quantidade

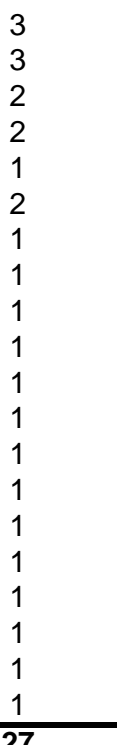

Número de espécies capturadas- Nova Brasilândia (MT) Janeiro a Outubro de 2009

\begin{tabular}{lccc}
\hline & Nome popular & Nome científico & Quantidade \\
Equídeos & Equus & & 217 \\
\hline
\end{tabular}

Número de espécies capturadas- Pinhal (RS) Janeiro de 2009

Nome popular

Piru-piru Nome popular

bobo-grande-de-sobre-branco

Haematopus palliatus

Nome científico

Quantidade

petrel-gigante

batuiruçu

Puffinus gravis

Macronectes giganteus

Pluvialis dominica

pardela-preta

Procellaria aequinoctialis

albatroz-de-nariz-amarelo

Thalasarche chlororhynchos

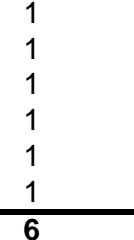




\begin{tabular}{llc|}
\hline Número de espécies capturadas- Bom Princípio (RS) Janeiro de 2009 & \multicolumn{1}{c|}{ Nome científico } \\
\hline \multirow{2}{*}{ Nome popular } & \multicolumn{1}{c}{ Qolothrus bonariensis } & 3 \\
Vira-bosta & Columbina talpacoti & 3 \\
Rolinha-roxa & Myophobus fasciatus & 1 \\
filipe & Sicalis flaveola & 33 \\
Canário-da-terra-verdadeiro & Troglodytes musculus & 1 \\
Curuíra & Coryphospingus cucullatus & 1 \\
Tico-Tico-rei & Saltator simis & 1 \\
Trinca-ferro-verdadeiro & Furnarius ruffus & 2 \\
João-de-barro & Zonotrichia capensis & 2 \\
Tico-tico & Turdus sp. & 1 \\
Sabiá & Turdus rufiventris & 1 \\
Sabiá-laranjeira & Tyrannus melancholicus & 1 \\
Suiriri & Elaenia obscura & 1 \\
Tucão & Total & $\mathbf{5 1}$
\end{tabular}

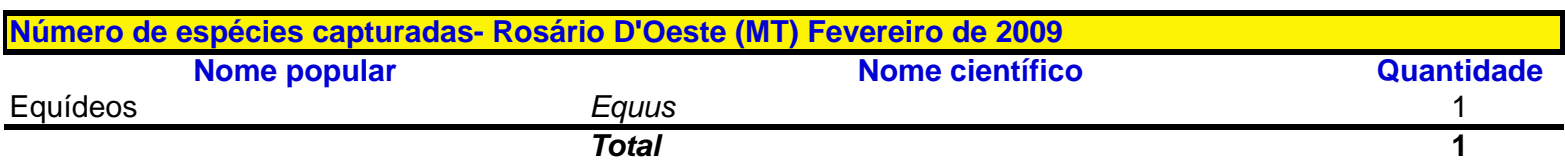

\begin{tabular}{|c|c|c|}
\hline Nome popular & Nome científico & Quantidade \\
\hline Equídeos & Equus & 1 \\
\hline
\end{tabular}

Número de espécies capturadas- Tupandi (RS) Fevereiro de 2009

\begin{tabular}{llc}
\hline \multicolumn{1}{c}{ Nome popular } & \multicolumn{1}{c}{ Nome científico } & Quantidade \\
Pardal & Passer Domesticus & 2 \\
Tico-tico-rei & Coryphospingus cucullatus & 5 \\
Coruira & Troglodytes musculus & 1 \\
Juriti-pupu & Leptotila verreauxi & 1 \\
Anu branco & Guira guira & 1 \\
Rolinha roxa & Columbina talpacoti & 1 \\
Tico-tico & Zonotrichia capensis & 1 \\
Canario da terra verdadeiro & Sicalis flaveola & 5 \\
\hline
\end{tabular}

Número de espécies capturadas- Pinhal (RS) Fevereiro e Março de 2009

trinta-reis-boreal Nome popular

bobo-peuqeno

Sterna hirundo Nome científico

Quantidade

Pardela-de-oculos

Puffinus puffinus

Albatroz de nariz amarelo

Bobo-grande-de-sobre-branco

Procellaria conspicillata

Thalassarche cholorynchos

Puffinus gravis

Rolinha roxa

Pariri

Columbina talpacoti

Geotrygon montana

Total

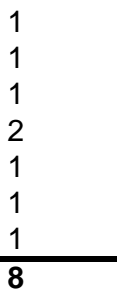

Número de espécies capturadas- Santo Antônio Leverger (MT) Fevereiro a Setembro de 2009

\begin{tabular}{llcc}
\hline & Nome popular & Nome científico & Quantidade \\
Equídeos & Equus & 40 \\
\hline & Total & 40
\end{tabular}


Número de espécies capturadas- Feliz (RS) Março de 2009

pula-pula-assobiador

Nome popular

chupa-dente

cambacica

Coruira

tié-do-mato-grosso

trinca-ferro

pula-pula

sabia-laranjeira

Tico-tico

tangará

Pica-pau-anao-de-coleira

\begin{tabular}{lc}
\multicolumn{1}{c}{ Nome científico } & Quantidade \\
Basileuterus leucoblepharus & 3 \\
Conopophaga lineata & 2 \\
Coereba flaveola & 1 \\
Troglodytes musculus & 1 \\
Habia rubica & 1 \\
Saltator similis & 1 \\
Basileuterus culicivorus & 3 \\
Turdus rufiventris & 2 \\
Zonotrichia capensis & 2 \\
Chiroxiphia caudata & 1 \\
Picunnus temminckii & 1 \\
\hline Total & $\mathbf{1 8}$
\end{tabular}

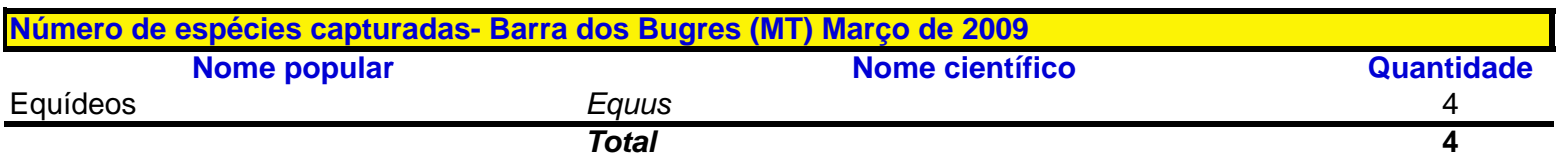

Número de espécies capturadas- Arenápolis (MT) Março de 2009

\begin{tabular}{cccc}
\hline & Nome popular & Nome científico & Quantidade \\
Equídeos & Equus & & 3 \\
\hline & Total & 3
\end{tabular}

Número de espécies capturadas- Nova Mutum (MT) Março de 2009

\begin{tabular}{llcc}
\hline & Nome popular & Nome científico & Quantidade \\
Equídeos & Equus & 39 \\
\hline & Total & 39
\end{tabular}

\begin{tabular}{|lccc|}
\hline \multicolumn{2}{|l}{ Número de espécies capturadas- Planalto da Serra (MT) } & Março a Novembro de 2009 & Quantidade \\
Equídeos & Nome popular & Nome científico & 146 \\
\hline & Equus & & 146
\end{tabular}

Número de espécies capturadas- Bom Principio (RS) Abril de 2009

\section{Nome popular}

joao-de-barro

Rolinha roxa

Tico-tico

sanhaço-cinzento

tangará

rolinha-picui

Coruira

sabia-laranjeira

bem-te-vi

\section{Nome científico}

Furnarius rufus

Columbina talpacoti

Zonotrichia capensis

Thraupis saiata

Chiroxiphia caudata

Columbina picui

Troglodytes musculus

Turdus rufiventris

Pitangus sulphuratus

Total
Quantidade

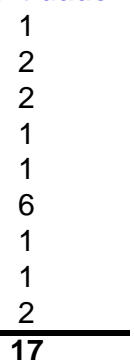

Número de espécies capturadas- Pinhal (RS) Abril de 2009

\section{Nome popular}

Bobo-grande -de-sobre-branco

pato-do-mato

gaivotão

pardela-preta

pardela
Puffinus gravis

Cairina moschata

Larus dominicanus

Procellaria aequinoctialis

Procellaria $s p$

\section{Nome científico}

Quantidade

Total

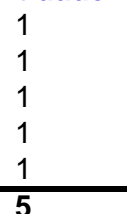




\begin{tabular}{llc}
\hline Número de espécies capturadas- Ilha de Canelas (PA) Abril de 2009 & \multicolumn{1}{c|}{ Nome científico } \\
\hline & \multicolumn{1}{c}{ Nome popular } & Quantidade \\
Marreco & Dendrocygna autumnalis & 18 \\
Marreco & Dendrocygna viduata & 3 \\
Colhereiro & Platalea ajaja & 2 \\
Trinta-réis & Thalasseus sandvicensis & 1 \\
Marreco & Amazonetta brasiliensis & 1 \\
maçarico-de-costas-brancas & Limnodromus griseus & 2 \\
Maçarico-rasteiro & Calidris pusilla & 64 \\
Batuíra-de-coleira & Charadrius collaris & 2 \\
Figuinha-do-mangue & Conirostrum bicolor & 1 \\
Bate-bunda & Actitis macularius & 24 \\
Batuíra-de-bando & Charadrius semipalmatus & 1 \\
Martin-pescador & Ceryle torquatus & 1 \\
Vira-pedras & Arenaria interpres & 9 \\
Maçarico & sp. & 7 \\
\hline
\end{tabular}

\begin{tabular}{|c|c|c|}
\hline Nome popular & Nome científico & Quantidade \\
\hline Equídeos & Equus & 64 \\
\hline
\end{tabular}

Número de espécies capturadas- Tupandi (RS) Maio de 2009

\begin{tabular}{llc}
\multicolumn{1}{c}{ Nome popular } & Nome científico & Quantidade \\
sabia-laranjeira & Turdus rufiventris & 7 \\
pula-pula & Basileuterus culicivorus & 1 \\
Tico-tico & Zonotrichia capensis & 1 \\
joao-de-barro & Furnarius rufus & 1 \\
mergulhao-grande & Podiceps major & 1 \\
\hline
\end{tabular}

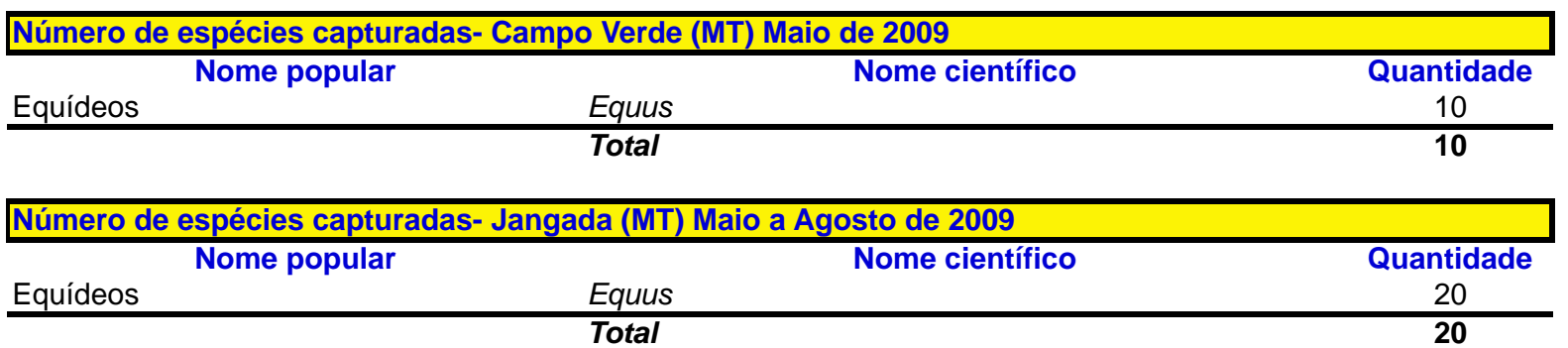

\begin{tabular}{llc|}
\hline Número de espécies capturadas- Feliz (RS) Junho de 2009 & \multicolumn{1}{c|}{ Nome científico } \\
\hline \multicolumn{1}{c}{ Nome popular } & Quantidade \\
pula-pula-assobiador & Furnarius rufus & 4 \\
joao-de-barro & Mackenziaena leachi & 1 \\
boralhara-assobiador & Conopophaga lineata & 1 \\
chupa-dente & Habia rubica & 1 \\
tié-do-mato-grosso & Poospiza lateralis & 1 \\
quete & Turdus rufiventris & 1 \\
sabia-laranjeira & Saltator similis & 3 \\
trinca-ferro & Pocilotriccus plumbeiceps & 1 \\
tororó & Total & 1 \\
\hline
\end{tabular}




\begin{tabular}{|c|c|c|}
\hline \multicolumn{3}{|c|}{ Número de espécies capturadas- Pinhal (RS) Junho de 2009} \\
\hline Nome popular & Nome científico & Quantidade \\
\hline pingüin-de-magalhães & Spheniscus magellanicus & 5 \\
\hline galinha domestica & Gallus gallus & 2 \\
\hline & Total & 7 \\
\hline
\end{tabular}

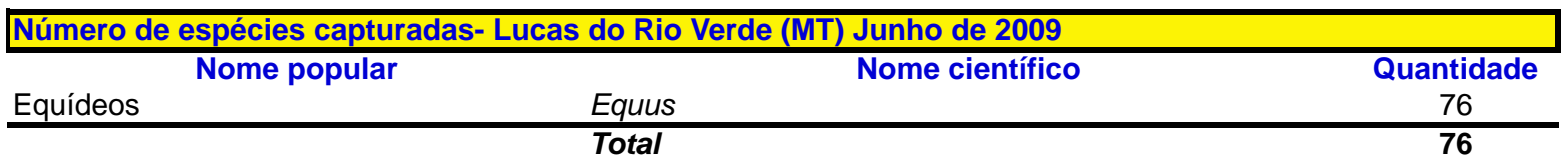

Número de espécies capturadas- Bom Principio (RS) Julho de 2009 Nome popular

canário-da-terra

joao-de-barro

bem-te-vi

Rolinha roxa

sabia-barranco

sabia-laranjeira

rolinha-picul

pula-pula

Tico-tico-rei

Coruira

Nome científico

Quantidade

Sicalis flaveola

Furnarius rufus

Pitangus sulphuratus

Columbina talpacoti

Turdus leucomelas

Turdus rufiventris

Columbina picui

Basileuterus culicivorus

Coryphospingus cucullatus

Troglodytes musculus

Total

\begin{tabular}{c}
10 \\
8 \\
1 \\
4 \\
1 \\
1 \\
1 \\
1 \\
1 \\
1 \\
\hline
\end{tabular}

Número de espécies capturadas- Diamantino (MT) Julho de 2009

\begin{tabular}{llrc}
\hline & Nome popular & Nome científico & Quantidade \\
Equídeos & Equus & 10 \\
\hline & Total & 10
\end{tabular}

\begin{tabular}{|c|c|c|}
\hline \multicolumn{3}{|c|}{ Número de espécies capturadas- Pinhal (RS)Agosto de 2009} \\
\hline Nome popular & Nome científico & Quantidade \\
\hline pingüin-de-magalhães & Spheniscus magellanicus & 86 \\
\hline pardelão-prateado & Fulmarus glacialoides & 2 \\
\hline petrel-gigante & Macronectes giganteus & 2 \\
\hline pardela-preta & Procellaria aequinoctialis & 2 \\
\hline albatroz-de-sombrancelha & Thalassarche melanophris & 2 \\
\hline
\end{tabular}

Número de espécies capturadas- Bom Principio (RS) Agosto de 2009

Rolinha roxa Nome popular

saracura-do-mato

vira-bosta

canário-da-terra

quete

coruira

pia-cobra

Tico-tico

sabia-laranjeira

tié-de-topete

Tico-tico-rei

rolinha-picui

Columbina talpacoti

Nome científico

Quantidade

sabia-poca

Aramides saracura

Molothrus bonariensis

Sicallis flaveola

Poospiza lateralis

Troglodytes musculus

Geothlypis aequinoctialis

Zonotrichia capensis

Turdus rufiventris

Trichothraupis melanops

Coryphospingus cucullatus

Columbina picui

Turdus amaurochalinus 


\begin{tabular}{llc|}
\hline \multicolumn{2}{|c|}{ Número de espécies capturadas- Pinhal (RS) Setembro de $\mathbf{2 0 0 9}$} & Nome científico \\
\hline \multicolumn{1}{c}{ Nome popular } & Quantidade \\
pingüin-de-magalhães & Puffinus puffinus & 21 \\
bobo-pequeno & Pterodroma inserta & 3 \\
Grazina-de-barriga-branca & Thalassarche melanophris & 1 \\
albatroz-de-sombrancelha & Thalassarche chlororhynchos & 2 \\
Albatroz-de-nariz-amarelo & Total & 1 \\
\hline
\end{tabular}

\begin{tabular}{llc|}
\hline \multicolumn{2}{|c|}{ Número de espécies capturadas- Presidente Lucena (RS) } & Setembro de 2009 \\
\hline \multicolumn{1}{|c|}{ Nome popular } & Nome científico & Quantidade \\
galinha-doméstica & Gallus gallus & 17 \\
Peru-doméstico & Meleagris gallopavo & 2 \\
Maritaca-verde & Pionos maximiliane & 1 \\
\hline & Total & 20
\end{tabular}

\begin{tabular}{|c|c|c|}
\hline Número de espécies captur & a Grande (MT) Setembro de 2009 & \\
\hline $\begin{array}{ll} & \text { Nome popular } \\
\text { Equídeos } & \end{array}$ & Nome científico & $\begin{array}{c}\text { Quantidade } \\
1\end{array}$ \\
\hline & Total & 1 \\
\hline
\end{tabular}

\begin{tabular}{llc|}
\hline Número de espécies capturadas- Ilha de Canelas (PA) Outubro de 2009 \\
\hline \multicolumn{1}{c}{ Nome popular } & \multicolumn{1}{c|}{ Nome científico } \\
Marreco & Dendrocygna autumnalis & 68 \\
Marreco & Dendrocygna viduata & 3 \\
Marreco & Amazonetta brasiliensis & 1 \\
Guará & Eudocimus ruber & 1 \\
Maçarico-rasteiro & Calidris pusilla & 42 \\
Bate-bunda & Actitis macularius & 18 \\
Batuíra-de-bando & Charadrius semipalmatus & 17 \\
Maçarico-branco & Calidris alba & 1 \\
Maçariquinho & Calidris minutilla & 2 \\
\hline
\end{tabular}

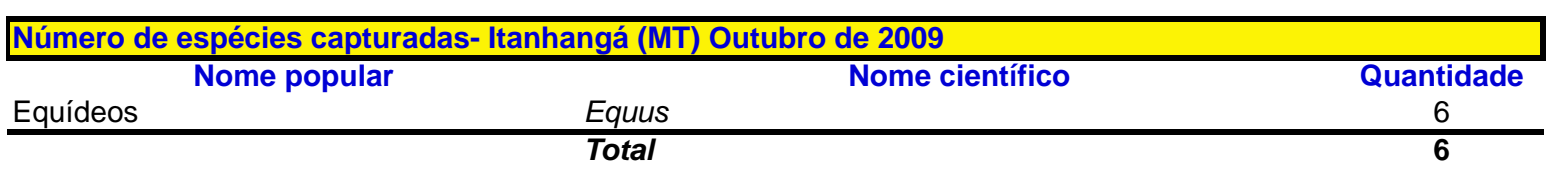

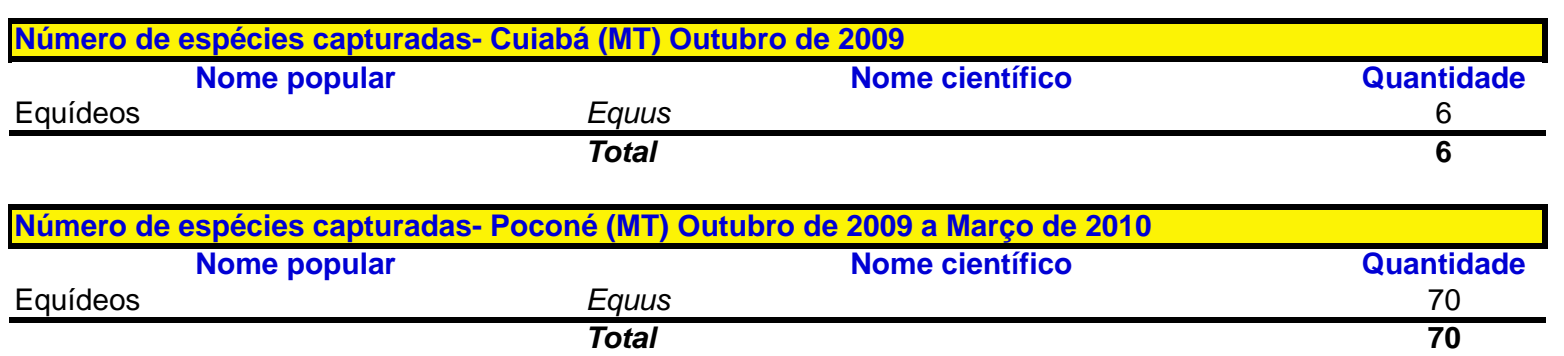




\begin{tabular}{llc|}
\hline Número de espécies capturadas- Parque Nacional da Lagoa do Peixe (RS) Novembro de 2009 \\
\hline Talha-Mar & Rome popular & Quantidade \\
Maçarico & Calidris fuscicolis & 67 \\
Piru-piru & Haematopus palliatus & 67 \\
Pernilongo & Himantopus melanurus & 6 \\
batuiruçu & Pluvialis dominica & 2 \\
vira-pedras & Arenaria interpres & 7 \\
Maçarico-do peito-vermelho & Calidris canutus & 4 \\
Maçarico de peito branco & Calidris alba & 3 \\
Maçarico-rasteiro & Calidris pusilla & 6 \\
narceja-de-bico-torto & Nycticryphes semicollaris & 1 \\
Gaivotão & Larus dominicanus & 1 \\
pingüin-de-magalhães & Spheniscus magellanicus & 2 \\
Frango d'agua & Fulica leucoptera & 10 \\
bobo-grande-de-sobre-branco & Puffinus gravis & 1 \\
bobo-pequeno & Puffinus puffinus & 1 \\
maçarico-de-perna-amarela & Tringa flavipes & 3 \\
trinta-reis-boreal & Sterna hirundo & 2 \\
Biguá & Phalacrocorax brasilianus & 15 \\
Quero-quero & Vanellus chilensis & 2 \\
Passeriforme & Elaenia mesoleuca & 1 \\
Maçarico de suvaco preto & Pluvialis squatarola & 1 \\
Canelado & Tryngites subruficollis & 1 \\
Maçarico & Calidris melanotus & 7 \\
Trinta-réis & Sterna vitatta & 1 \\
& Total & 1 \\
\hline Número de espécies capturadas- Juruena (MT) Novembro de 2009 & $\mathbf{2 1 2}$ \\
\hline \multirow{2}{*}{ Equídeos } & Equus & 218 \\
\hline
\end{tabular}

Número de espécies capturadas- Ilha de Canelas (PA) Dezembro de 2009

\begin{tabular}{llc}
\hline \multicolumn{1}{c}{ Nome popular } & Nome científico & Quantidade \\
Talha-mar & Rynchops niger & 1 \\
Martim-pescador-verde & Chloroceryle amazona & 1 \\
Maçariquinho & Calidris minutilla & 5 \\
Maçarico-branco & Calidris alba & 2 \\
Maçarico-rasteiro & Calidris pusilla & 109 \\
Bate-bunda & Actitis macularius & 81 \\
Maçarico-galego & Numenius phaeopus & 1 \\
Batuíra-de-bando & Charadrius semipalmatus & 74 \\
Vira-pedras & Arenaria interpres & 3 \\
Alma-de-mestre & Oceanites oceanicus & 1 \\
Batuíra-de-coleira & Charadrius collaris & 1 \\
Sem identificação & Sem identificação & 1 \\
\hline
\end{tabular}

Sem identificação

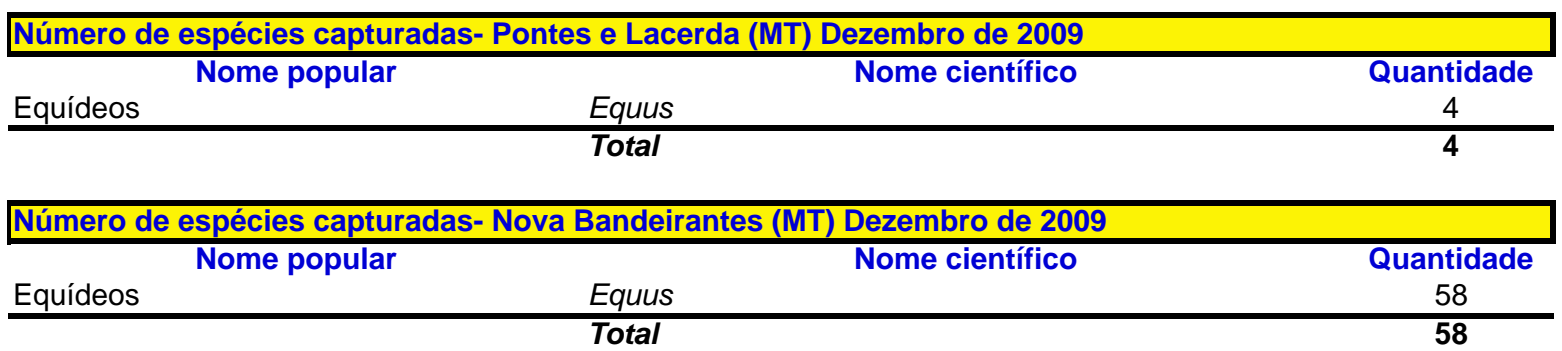


Número de espécies capturadas- Instituto Biológico de São Paulo 2010

\begin{tabular}{cccc}
\hline Cavalo & Nome popular & Nome científico & Quantidade \\
\hline & Equus & & 63 \\
\hline & Total & 63
\end{tabular}

Número de espécies capturadas- Cetas de Florianópolis (SC) Janeiro a Junho de 2010

\section{Nome popular}

grazina-de-barriga-branca

Gaivotão

pingüin-de-magalhães

fragata-comum

atobá-pardo

flautim

arapaçu-liso

arapaçu-verde

choquinha-lisa

capitão-de-saíra

Tiririzinho-do-mato

Cuspidor-de-máscara-preta

rolinha-roxa

tico-tico-rei

albatroz-de-nariz-amarelo

albatroz-de-sombrancelha

atobá-pardo petrel-gigante-do-norte

\section{Nome científico}

Macronectes halli

Pterodroma incerta

Larus dominicanus

Spheniscus magellanicus

Fregata magnificens

Sula leucogaster

Schiffornis virescens

Dendrocincla turdina

Sittasomus griseicapillus

Dysithamnus mentalis

Attila rufus

Hemitriccus orbitatus

Conopophaga melanops

Columbina talpacoti

Coryphospingus cucullatus

Thalassarche chlororhynchos

Thalassarche melanophris Sula leucogaster

Tota
Quantidade

1

2

14

1

1

1

1

1

1

1

4

43

Número de espécies capturadas- Pinhal (RS) Março a Setembro de 2010 Nome popular

pingüin-de-magalhães

maçarico-branco

Maçarico-do peito-vermelho

Gaivota

pardela-de-bico-amarelo

Pernilongo

pardela-preta

petrel-gigante

Albatroz-de-nariz-amarelo

bobo-pequeno Nome científico

Gallinula chloropus

Spheniscus magellanicus

Calidris alba

Calidris canutus

Chroicocephalus maculipennis

Calonectris borealis

Himantopus melanurus

Procellaria aequinoctialis

Macronectes giganteus

Thalassarche chlororhynchos

Puffinus puffinus $\quad 2$

Plegadis chihi

caraúna-de-cara-branca
Quantidade

1

57

1

2

6

3 
Número de espécies capturadas-Parque Nacional da Lagoa do Peixe (RS) Março de 2010

Trinta-réis

Maçarico

Maçarico-do peito-vermelho

Batuíra

Batuíra-de-bando

Gaivota

Trinta-réis

Batuíra-de-coleira

trinta-reis-boreal

Bobo grande

Pardela Preta

Maçarico-rasteiro

Pernilongo

Trinta-réis

Maçarico de suvaco preto

Maçarico-de-perna-amarela

petrel-gigante

albatroz-de-sombrancelha

vira-pedras

Quero-quero
Nome científico

Sterna trudeaui

Calidris fuscicolis

Calidris canutus

Charadrius falklands

Charadrius semipalmatus

Chroicocephalus maculipennis $\quad 2$

Sterna eurigynatha

Charadrius collaris

Sterna hirundo

Calonectris dionedea

Procelaria aecnoctialis

Calidris pusilla

Himantopus melanurus

Sterna superciliaris

Pluvialis squatarola

Tringa melanoleuca

Macronectes giganteus

Thalassarche melanophris

Arenaria interpres

Vanellus chilensis

Total
Quantidade

13

109

19

1

4

1

2

11

1

1

6

1

4

3

2

1

1

1

1

184

Número de espécies capturadas- Tavares (RS) Setembro de 2010

Nome popular

Quero-quero

maçarico-de-sobre-branco

Batuíra-de-bando

piru-piru

trinta-réis-de-bico-vermelho

Canelado

Maçarico-do peito-vermelho

trinta-reis-boreal

Nome científico

Quantidade

Vanellus chilensis

Calidris fuscicollis

Charadrius semipalmatus

Haematopus palliatus

Sterna hirundinacea

Tryngites subruficollis

Calidris canutus

Sterna hirundo

Total

2

11

1

13

4

9

1

1

42

Número de espécies capturadas- Pinhal (RS) Outubro a Dezembro de 2010

Nome popular

petrel-gigante

Nome científico

bobo-pequeno

Macronectes giganteus

Nome científico

Puffinus puffinus

Thalassarche melanophrys

pardela-preta

Biguá

Gavião

grazina-mole

bobo-grande-de-sobre-branco

Procellaria aequinoctialis

Phalacrocorax brasilianus

Buteo sp.

Pterodroma mollis

Gaivotão

piru-piru

Puffinus gravis

Larus dominicanus

pingüin-de-magalhães

bobo-grande

Grazina-de-barriga-branca

Haematopus palliatus

Spheniscus magellanicus

Calonectris diomedea

Pterodrama incerta

pardela-de-bico-amarelo

Calonectris borealis 


\begin{tabular}{llc|}
\hline Número de espécies capturadas- Tavares (RS) Março de 2011 & Quantidade \\
\hline \multicolumn{1}{c}{ Nome popular } & Rome científico & 7 \\
Talha-Mar & Charadrius semipalmatus & 14 \\
Batuíra-de-bando & Arenaria interpres & 4 \\
vira-pedras & Calidris fuscicollis & 92 \\
maçarico-de-sobre-branco & Calidris alba & 1 \\
maçarico-branco & Tringa flavipes & 3 \\
maçarico-de-perna-amarela & Thalassarche melanophrys & 2 \\
Albatroz-de-sobrancelha & Calonectris borealis & 1 \\
pardela-de-bico-amarelo & Charadrius collaris & 1 \\
Batuíra-de-coleira & Calidris pusilla & 3 \\
Maçarico-rasteiro & Chroicocephalus maculipennis & 1 \\
Gaivota & Calidris canutus & 7 \\
Maçarico-do peito-vermelho & Total & 136 \\
\hline
\end{tabular}

Número de espécies capturadas- Ilha de Canelas (PA) Abril de 2010

\begin{tabular}{llc}
\hline \multicolumn{1}{c}{ Nome popular } & Nome científico & Quantidade \\
Trinta-réis & Actitis macularius & 88 \\
Maçariquinho & Calidris minutilla & 1 \\
Maçarico-do peito-vermelho & Calidris canutus & 1 \\
Batuíra-de-bando & Charadrius semipalmatus & 12 \\
Batuíra-de-coleira & Charadrius collaris & 9 \\
Maçarico-rasteiro & Calidris pusilla & 118 \\
vira-pedras & Arenaria interpres & 2 \\
Maçarico & sem identificacao & 4 \\
\hline
\end{tabular}

Número de espécies capturadas- Bate Vento e Iguará (MA) Maio de 2010

Maçarico-rasteiro Nome popular

Batuíra-de-bando

maçarico-de-costas-brancas

Maçarico-do peito-vermelho

Vira-pedras

Bate-bunda

Pernilongo

Quero-quero

Piru-piru

Marreco-silvestre

Marreco-silvestre

Marreco-silvestre

Jaçanã

Saracura

Trinta-réis

Gaivota

Garça-azul

Garça-branca-grande

Batuíra-de-coleira

Skua

Garça-branca

\section{Nome científico}

Quantidade

Calidris pusilla

Charadrius semipalmatus

Limnodromus griseus

Calidris canutus

Arenaria interpres

Actitis macularius

mexicanus $\quad 25$

Vanellus chilensis

Haemantopus palliatus

Dendrocygna viduata

Amazonetta brasiliensis

Jacana jacana 2

Aramides saracura $\quad 2$

Geochelida nilotica 4

Larus macullipenis 1

Egretta caerulea 1

Ardea alba 2

Charadrius collaris $\quad 6$

Catharata skua 2

Egretta thula 1

Número de espécies capturadas- Arquipélago Fernando de Noronha (PE) Agosto de 2010

\begin{tabular}{llc}
\multicolumn{1}{c}{ Nome popular } & Nome científico & Quantidade \\
rabo-de-palha-de-bico-laranja & Phaeton lepturus & 35 \\
pardela-de-asa-larga & Puffinus lherminieri & 2 \\
\hline & Total & 37
\end{tabular}


Número de espécies capturadas- Ilha de Canelas (PA) Novembro de 2010

\begin{tabular}{|c|c|c|}
\hline Nome popular & Nome científico & $\begin{array}{c}\text { Quantidade } \\
90\end{array}$ \\
\hline $\begin{array}{l}\text { Trinta-réis } \\
\text { Batuíra-de-bando }\end{array}$ & Actitis macularius & $\begin{array}{l}90 \\
38\end{array}$ \\
\hline $\begin{array}{l}\text { Batuíra-de-bando } \\
\text { Macarico-rasteiro }\end{array}$ & Charadrius semipalmatus & 64 \\
\hline Vira -pedras & Arenaria interpres & 6 \\
\hline Maçariquinho & Calidris minutilla & 2 \\
\hline maçarico-de-costas-brancas & Limnodromus griseus & 1 \\
\hline & Total & 201 \\
\hline \multicolumn{3}{|c|}{ Número de espécies capturadas- Arquipélago Fernando de Noronha (PE) Agosto de 2010} \\
\hline Nome popular & Nome científico & Quantidade \\
\hline rabo-de-palha-de-bico-vermelho & Phaeton aethereus & 2 \\
\hline rabo-de-palha-de-bico-laranja & Phaeton lepturus & 22 \\
\hline pardela-de-asa-larga & Puffinus Iherminieri & 1 \\
\hline
\end{tabular}

Número de espécies capturadas- Pinhal (RS) Maio a Outubro de 2011

\begin{tabular}{llc}
\hline \multicolumn{1}{c}{ Nome popular } & \multicolumn{1}{c}{ Nome científico } & Quantidade \\
bobo-grande & Calonectris diomedea & 2 \\
gavião-caboclo & Heterospizias meridionalis & 1 \\
Faigão-de-bico-largo & Pachyptila desolata & 2 \\
Biguá & Phalacrocorax brasilianus & 1 \\
pardela-preta & Procellaria aequinoctialis & 9 \\
bobo-grande-de-sobre-branco & Puffinus gravis & 1 \\
bobo-pequeno & Puffinus puffinus & 6 \\
pingüin-de-magalhães & Spheniscus magellanicus & 72 \\
trinta-réis-de-bico-vermelho & Sterna hirundinacea & 1 \\
trinta-reis-boreal & Sterna hirundo & 1 \\
Albatroz-de-nariz-amarelo & Thalassarche chlororhynchos & 1 \\
Albatroz-de-sobrancelha & Thalassarche melanophrys & 5 \\
\hline
\end{tabular}

Número de espécies capturadas- Tavares (RS) Outubro e Novembro de 2011

Cochicho

Maçarico-do peito-vermelho

maçarico-de-sobre-branco

maçarico-pernilongo

Maçarico-rasteiro

Batuíra-de-bando

Garça-branca

piru-piru

Perna-longa

petrel-gigante

narceja-de-bico-torto

Talha-Mar

batuiruçu

trinta-reis-boreal

maçarico-de-perna-amarela

Maçarico-de-perna-amarela

Quero-quero

Canelado

\section{Nome científico}

Anumbius annumbi

Calidris canutus

Calidris fuscicollis

Calidris himantopus

Calidris pusilla

Charadrius semipalmatus

Egretta thula

Haematopus palliatus

Himantopus himantopus

Macronectes giganteus

Nycticryphes semicollaris

Rynchops niger

Pluvialis dominica

Sterna hirundo

Tringa flavipes

Tringa melanoleuca

Vanellus chilensis

Tryngites subruficollis
Quantidade

1

7

22

2

1

1

14

24

3

3 


\begin{tabular}{llc}
\hline \multicolumn{2}{|c|}{ Número de espécies capturadas-Parque Nacional da Lagoa do Peixe (RS) Novembro de 2011 } \\
\hline \multicolumn{1}{c}{ Nome popular } & Nome científico & Quantidade \\
trinta-reis-boreal & Sterna hirundo & 51 \\
Maçarico & Calidris fuscicolis & 1 \\
Pernilongo & Himantopus melanurus & 30 \\
Talha-Mar & Rynchops niger & 5 \\
\hline & Total & $\mathbf{8 7}$
\end{tabular}

Número de espécies capturadas- Pinhal (RS) Abril de 2012

\begin{tabular}{llc}
\hline \multicolumn{1}{c}{ Nome popular } & \multicolumn{1}{c}{ Nome científico } & Quantidade \\
bobo-grande & Calonectris diomedea & 5 \\
piru-piru & Haematopus palliatus & 3 \\
Alma-de-mestre & Oceanites oceanicus & 1 \\
pardela-preta & Procellaria aequinoctialis & 1 \\
grazina-de-barriga-branca & Pterodroma incerta & 1 \\
bobo-grande-de-sobre-branco & Puffinus gravis & 9 \\
bobo-pequeno & Puffinus puffinus & 5 \\
Talha-Mar & Rynchops niger & 1 \\
pingüin-de-magalhães & Spheniscus magellanicus & 2 \\
trinta-réis-de-bico-vermelho & Sterna hirundinacea & 1 \\
Albatroz-de-sobrancelha & Thalassarche melanophrys & 1 \\
\hline
\end{tabular}

Número de espécies capturadas- Tavares (RS) Abril de 2012

\begin{tabular}{llc}
\hline \multicolumn{1}{c}{ Nome popular } & Nome científico & Quantidade \\
vira-pedras & Arenaria interpres & 1 \\
maçarico-branco & Calidris alba & 17 \\
Maçarico-do peito-vermelho & Calidris canutus & 5 \\
maçarico-de-sobre-branco & Calidris fuscicollis & 68 \\
Maçarico-rasteiro & Calidris pusilla & 2 \\
batuíra-de-peito-tijolo & Charadrius modestus & 1 \\
Batuíra-de-bando & Charadrius semipalmatus & 8 \\
Garça-branca & Egretta thula & 1 \\
piru-piru & Haematopus palliatus & 2 \\
Maçarico de suvaco preto & Pluvialis squatarola & 2 \\
Talha-Mar & Rynchops niger & 16 \\
trinta-réis-de-bico-vermelho & Sterna hirundinacea & 3 \\
trinta-reis-boreal & Sterna hirundo & 1 \\
trinta-réis-anão & Sterna superciliaris & 3 \\
trinta-réis-de-bando & Thalasseus acuflavidus & 2 \\
Quero-quero & Vanellus chilensis & 1 \\
\hline
\end{tabular}

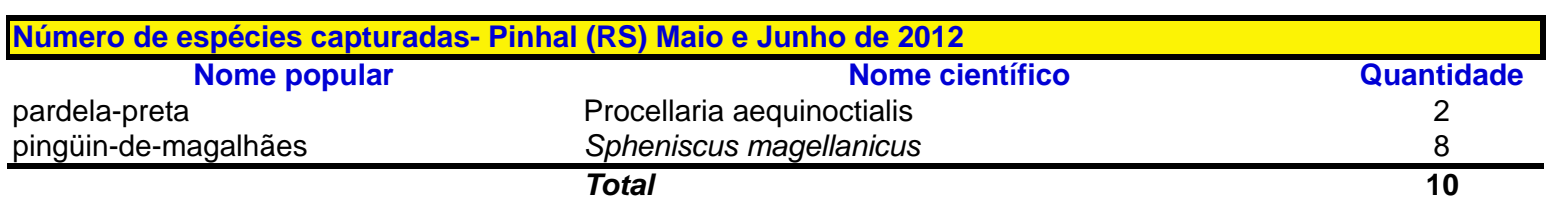

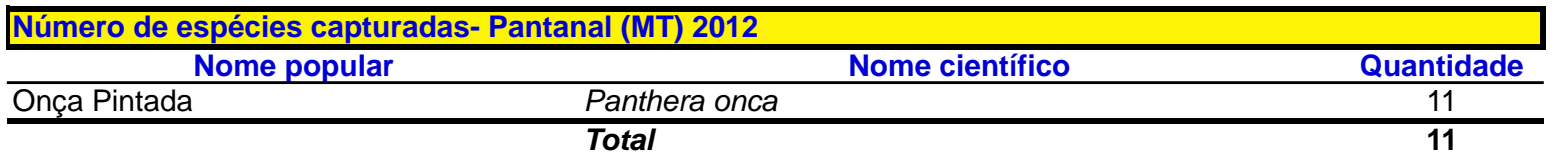


Número de espécies capturadas- Pantanal (MT) Novembro de 2012

João-de-barro Nome popular

Curutié

Sabiá-laranjeira

Pipira-vermelha

Tiziu (Esporofilo)

Olho-de-ouro

Trinca-ferro

Maria-cavaleira

Guaracava-de-crista-branca

Arapaçu

Galo-da-campina-pantaneiro

Coleirinho

Xexéu (guaxo amarelo), Japuíra

João-do-pantanal

Alegrinho-do-chaco

Guaracavuçu

Asa-de-telha

Rolinha-picui

Anhambé-de-boina

Pomba-galega

Sabiá-gongá

Irré

Morcegos

Pipira-preta

Ferreirinho-de-cara-parda

Soldadinho

Guaracava-de-crista-alaranjada

Canário-do-mato

Pica-pau-anão-escamado

Pipira-da-Touca

Papa-lagarta-de-euler

Picapauzinho-anão

Beija-flor-de-Rabo-branco-rubro)

Beija-flor-de-banda-branca

Chororó-do-pantanal

Ferreirinho-relógio

Curió

Chorozinho-de-bico-comprido

Gralha-do-Pantanal

Rolinha-roxa

Balança-rabo-de-máscara

Ariramba-de-cauda-ruiva

Fruxu-do-cerradão

Arredio-do-rio

Choca-do-planalto

Maria-cavaleira-de-rabo-enferrujado

Galinha de quintal

Equinos
Furnarius rufus

Nome científico

Certhiaxis cinnamomeus

Turdus rufiventris

Ramphocelus carbo

Volatinia jacarina

Hemitriccus margarita ceiventer

Saltator similis

Myiarchus ferox

Elaenia albiceps

Xiphorhynchus picus

Paroaria capitata

Sporophila caerulescens

Cacicus cela

Synallaxis albilora

Inezia inornata

Cnemotriccus fuscatus

Molothrus badius

Columbina picui

Tityra inquisitor

Columba cayennensis

Saltator coerulescens

Myiarchus swainsonii

Glossophaga soricina

Tachyphonus rufus

Poecilotriccus latirostris

Antilophia galeata

Myiopagis viridicata

Basileuterus flaveolus

Picumnus albosquamatus

Eucometes penicillata

Coccyzus euleri

Veniliornis passerinus

Phaethornis ruber

Amazilia versicolor

Cercomacra melanaria

Todirostrum labeatus

Sporophila angolensis

Herpsilochmus longirostris

Cyanocorax cianomelas

Columbina talpacoti

Polioptila dumicola

Galbula ruficauda

Neopelma pallescens

Cranioleuca vulpina

Thamnophilus pelzelni

Myiarchus tyrannus

Gallus gallus Equus
Quantidade

8

1

1

12

13

1

17

2

1

1

1

2

3

4

8

1

1

1

1

1

3

1

3

2

6

1

7 
APÊNDICE B - Artigo científico publicado

Trans R Soc Trop Med Hyg 2013; 107: $723-730$

\section{West Nile virus surveillance, Brazil, 2008-2010}

Tatiana Ometto ${ }^{a, *}$, Edison Luiz Durigon ${ }^{a}$, Jansen de Araujo ${ }^{a}$, Rosalie Aprelon ${ }^{b}$, Daniel Moura de Aguiarc, Guacyara Tenorio Cavalcanted, Rosane Marini Meloe, José Eduardo Levif, Severino Mendes de Azevedo Júniorg, Maria Virgínia Petryh, Isaac Simão Netoi, Patrícia Serafinii, Eliana Villalobosj, Elenice Maria Sequetin Cunhaj, Maria do

Carmo Custódio S. H. Laraj, Alessandra Ferreira Dales Navak, Marcello Schiavo Nardil, Renata Hurtadoa,m, Roberta Rodrigues ${ }^{g}$, Angelo Luís Shererh, Janete de Fátima Martins Shererh, Marcelo Plaisant Geraldif, Marina Maria Moraes de Seixas ${ }^{a}$, Cassio Peterkal, Debora de Souza Bandeiral, Jennifer Pradel ${ }^{b}$, Nathalie Vachieryb, Marcelo Bahia Labrunam $^{m}$, Luiz Marcelo Aranha de Camargo ${ }^{n}$, Robert Lanciottio and Thierry Lefrançois ${ }^{b}$

${ }^{a}$ BSL3+ Laboratório de Virologia Clínica e Molecular Instituto de Ciências Biomédicas (ICB), Universidade de São Paulo (USP), 05508-900 São Paulo, Brasil; ${ }^{b}$ CIRAD UMR CMAEE CIRAD-INRA, 97170 Petit Bourg, Guadeloupe, France; ' ${ }^{D}$ Departamento de Clínica Médica Veterinária, Universidade Federal do Mato Grosso (UFMT), 78060-900 Cuiabá, Brasil; ${ }^{d}$ Instituto de Física, Universidade de São Paulo, 05508-090 São Paulo, Brasil; ' Instituto de Defesa Agropecuária do Estado do Mato Grosso (INDEA), 78050-970 Cuiabá, Brasil; ' Laboratório de Virologia, Instituto de Medicina Tropical de São Paulo, Universidade de São Paulo, 05403-000 São Paulo, Brasil; ${ }^{9}$ Universidade Federal Rural de Pernambuco (UFRPE), 52171-900 Recife, Brasil; ' 'Universidade do Vale do Rio dos Sinos (UNISINOS), 93022-000 São Leopoldo, Brasil;

${ }^{i}$ Centro Nacional de Pesquisa e Conservação de Aves Silvestres (CEMAVE), 88053-700 Florianópolis, Brasil; ${ }^{j}$ Centro de Pesquisa e

Desenvolvimento de Sanidade Animal, Instituto Biológico, 04014-002 São Paulo, Brasil; ${ }^{k}$ EcoHealth Alliance, 05508-270 São Paulo, Brasil;

IInstituto de Pesquisas Ecológicas (IPÊ), 19280-000 Teodoro Sampaio, Brasil; 'mFaculdade de Medicina Veterinária e Zootecnia, Universidade de São Paulo, 05508-270 São Paulo, Brasil; Instituto de Ciências Biomédicas V, Universidade de São Paulo, 78965-300 Monte Negro, Brasil; ${ }^{\circ}$ Centers for Disease Control \& Prevention (CDC), 80521 Fort Collins, United States

*Corresponding author: Tel: +55 113091 7293; Fax: +55 113091 7354; E-mail: tatiometto@usp.br

Received 13 March 2013; revised 25 July 2013; accepted 31 July 2013

Background: West Nile virus (WNV) is an emergent pathogen that is widely distributed in North and Central America. The recent introduction in South America has focused attention on the spread of WNV across Southern American countries. The transmission network involves mosquitoes, birds, horses and humans.

Methods: The serological evaluation of sera from 678 equids and 478 birds was performed using a WNV-specific blocking ELISA, and only the positive results were confirmed by plaque reduction neutralisation tests (PRNTs). Molecular analysis was performed on sera from 992 healthy equids and on 63 macerates of brains from equids that died of encephalitis and had previously tested negative for other pathogens. We also tested swabs from 928 birds. The samples analysed were collected in different biomes of Brazil.

Results: We identified WNV antibodies by ELISA in thirteen equids and five birds, and PRNT 90 confirmed WNV positivity in four equid samples collected in 2009 in an area between the Amazon and the Pantanal. None of the ELISA positive bird samples were confirmed by PRNT $_{90}$, and all samples tested by RT-PCR were negative.

Conclusion: WNV circulation is confirmed by this large scale survey even in the absence of detection of clinical cases.

Keywords: West Nile virus, Serology, Molecular biology, Brazil, Equids, Migratory birds

\section{Introduction}

West Nile virus (WNV) is a mosquito-borne virus that belongs to the family Flaviviridae and the genus Flavivirus. WNV is maintained in nature by a mosquito-bird-mosquito cycle, and humans and other mammals act as dead-end hosts. ${ }^{1}$ Human and animal outbreaks of WNV with neurological disorders have provided warnings of the changing impact of WNV fever on animal and public health. ${ }^{2}$ WNV has emerged in the last three decades as a significant burden to public health and a major veterinary concern in Europe and the Americas. ${ }^{3}$ The emergence of WNV, particularly the invasion into North America in 1999 and its subsequent spread throughout the Western Hemisphere, ${ }^{3}$ corroborates the view that the virus is moving southward, placing millions of

(C) The Author 2013. Published by Oxford University Press on behalf of Royal Society of Tropical Medicine and Hygiene. All rights reserved. For permissions, please e-mail: journals.permissions@oup.com. 
T. Ometto et al.

individuals in South America and the Caribbean at risk for infection. ${ }^{1}$ WNV is now recognised as the most widespread of the flaviviruses, ${ }^{4}$ and the appearance in South American countries has stimulated intense interest. The first evidence of WNV activity in birds in South America was reported in Trinidad in $2004^{5}$ and in Argentina in 2005. ${ }^{6}$ Efforts to detect WNV-specific antibodies in resident and migrant birds in Brazil in 2002, 2003 and 2004 were unsuccessful. ${ }^{7-9}$ WNV seropositivity in horses in South America was first reported in Colombia in $2004^{10}$ and was subsequently reported in Venezuela, ${ }^{11}$ Argentina $^{6}$ and Brazil. ${ }^{2,12}$ The first report of WNV activity in South America surfaced in April 2006, when three horses died in Argentina. ${ }^{13}$ However, the established transmission foci in Argentina are unknown ${ }^{5}$ and have not yet been reported in Brazil. ${ }^{14} \mathrm{~A}$ study in Brazil published in 2011 analysed 8703 human samples from blood banks, none of which were positive for the presence of the virus. ${ }^{15}$ However, Brazil is a large tropical country with major ecological reserves that provide ideal conditions for many arboviruses, including WNV, ${ }^{16}$ and it would not be surprising for WNV to circulate in several areas and biomes. Brazil has six different biomes with some particularities. The Amazon is the largest biodiversity reserve in the world and is dominated by a hot and humid climate and forests. In the Cerrado, there is a predominance of savannah formations and a hot sub-humid tropical climate, a dry season and a rainy season. The Atlantic Forest is a complex that includes mountain ranges, valleys and plateaus, with tropical rain forest vegetation and a hot and humid climate. The Caatinga is defined by the drought, heat and light, resulting in a steppe-like, thorny and deciduous savannah vegetation. The Pampa is marked by rainy weather, with freezing temperatures in the winter and vegetation consisting of pampa grass and shrubs. The Pantana is characterised by long-term flooding; the predominant vegetation is savannah, but there are small areas of semi-deciduous and deciduous forests. Almost all of the Brazilian fauna are represented in the Brazilian Pantanal (Figure 1). ${ }^{17}$

Brazil has the largest herd of horses in Latin America and the third largest in the world. Including mules and donkeys, the total population is approximately 8 million head, equalling US\$3.2 billion including herd management costs. Export expansion reached 524\% between 1997 and 2009, from US\$702 800 to US\$4.4 million. Brazil is the eighth largest exporter of equine meat. ${ }^{18}$

Many questions regarding the potential for WNV spread in Brazi remain. The objective of this study was to address these questions by searching for evidence of WNV circulation in Brazil in resident equids and migratory and resident birds and by evaluating the importance of vaccinating horses before a possible Brazilian WNV outbreak.

\section{Materials and methods \\ Study design}

A serological survey was conducted of 678 equids, which were sampled between 2002 and 2009, and 478 birds, which were sampled between 2008 and 2010, in different Brazilian regions characterised by a variety of biomes (Figure 1 )

The molecular survey was conducted on 928 samples (oral/ cloacal swabs) from birds (2008 to 2010) and 992 serum samples from equids (2002 to 2009). We also performed molecular tests on the macerates of brains collected between 2008 and 2010 from 63 equids that died of encephalitis and had previously tested negative for other pathogens.

\section{Equid study area}

The sampled equids were privately owned and used primarily for cattle transport and handling. The equids were all asymptomatic at the time of sampling and had no history of vaccination against WNV or movement outside the area where they were sampled. For the retrospective study in 2002, we collected 99 samples, all tested by serological assay, in Monte Negro (Rondônia state) in the western Amazon. ${ }^{19}$ The State Park Morro do Diabo, which is located in southwestern São Paulo state, ${ }^{20}$ was the second retrospective study area from which 144 samples were collected in 2002 (86 equids) and 2006 (58 equids); all samples were tested by serological assay. The 2009 samples were collected in Mato Grosso state. There were a total of 570 samples of which, 217 were collected in Nova Brasilândia in the Cerrado region, and 218 collected from Juruena in northern Mato Grosso state. The remaining 135 (of the 570) samples came from 10 different cities in the same areas characterised by similar ecosystems and with increased farm activity, including Planalto da Serra, Arenápolis, Santo Antônio Leverger, Nova Bandeirantes, Jangada, Nova Mutum, Diamantino, Lucas do Rio Verde, Campo Verde and Poconé.

In addition, we performed molecular tests on the macerates of brains from 63 equids that died of encephalitis and had previously tested negative for herpes, rabies, western and eastern equine encephalitis, toxoplasma, Neospora and Sarcocystis. These samples were collected between 2008 and 2010 from the Southeast, Northeast and Central-West.

\section{Bird study area}

The sampled birds were migratory and resident, and asymptomatic or symptomatic at the time of sampling. The first sampling occurred in September 2008 in Glória city, Bahia state, in the Caatinga biome, with 71 samples collected and all tested by molecular assay. Between October 2008 and August 2009, we sampled 245 birds in the metropolitan region of Porto Alegre in the state of Rio Grande do Sul in four different city sites. All of these samples were tested by molecular assay, and 69 samples were tested by serology. In 2009, 400 bird samples were collected at Canela's Island in Pará state in the Amazon region, which is an important stopover site for migratory birds. All of these samples were tested by molecular assay, and 116 samples were tested by serology. From 2009 to 2010, we sampled 212 birds in the Lagoa do Peixe National Park in Rio Grande do Sul state. This national park is recognised as the largest migration point for birds in Brazil. ${ }^{8}$ All of these samples were tested by molecular assay, and 136 samples were tested by serology. In 2010, we collected samples from 142 birds in the Reentrâncias Maranhenses environmental protection area, Maranhão state, which has been designated by the Western Hemispheric Shorebird Reserve Network as an internationally important site that receives large populations of migratory birds. ${ }^{21}$ All of these samples were tested by serological assay. The last sampling was conducted in 19 birds in Fernando de Noronha Island, Pernambuco state, which is an oceanic island 


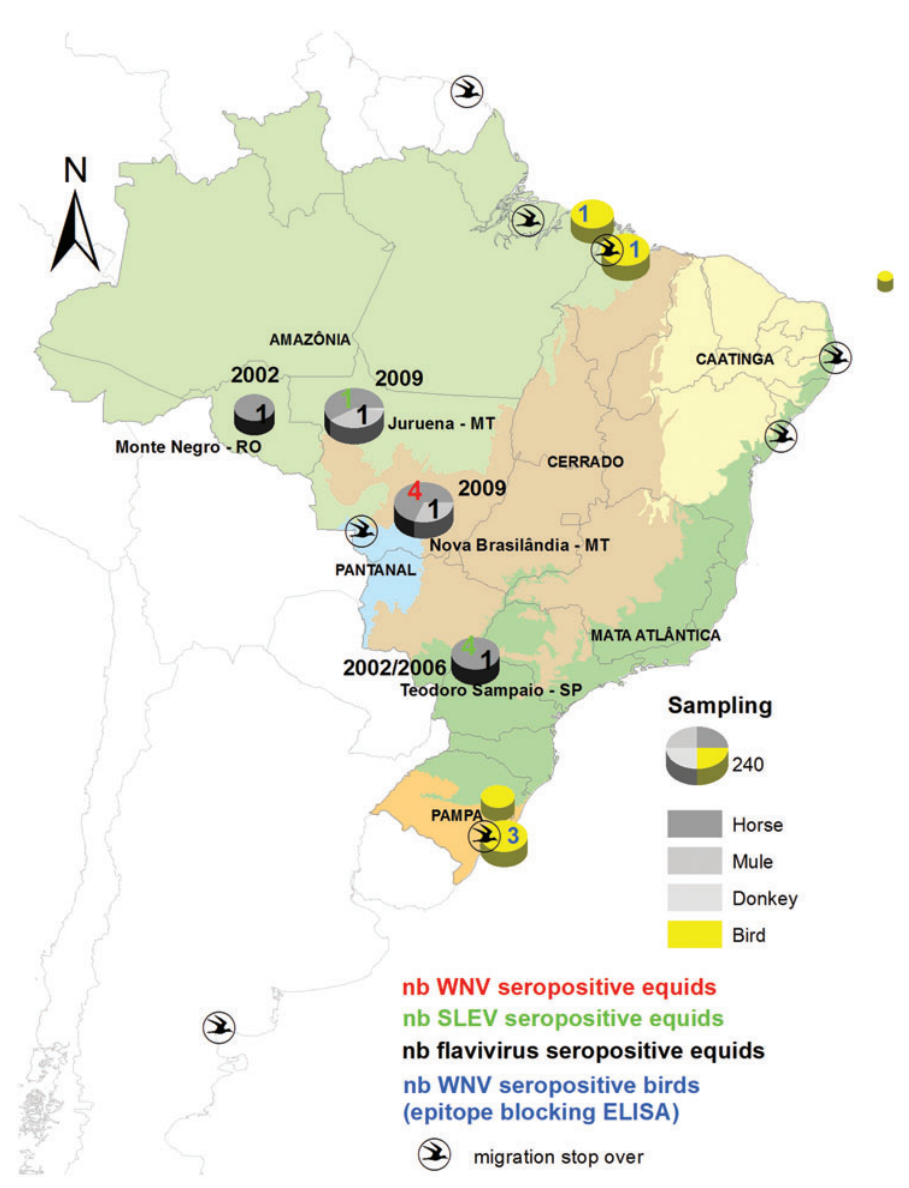

Figure 1. Site and year of sampling, major Brazilian biomes and serological results. The major biomes of Brazil are indicated by different colours as follows: Amazonia (light green), Cerrado (light brown), Pantanal (blue), Mata Atlantica (dark green), Caatinga (yellow) and Pampa (orange). The grey lines represent the borders of the Brazilian states. MT: Mato Grosso state; nb: number of; RO: Rondônia state; SLEV: St Louis encephalitis virus; SP: São Paulo state; WNV: West Nile virus.

located on the Brazilian coast. All samples were tested by molecular assay, and 15 were analysed by serological assay.

\section{Serologic tests}

Blocking ELISAs

ELISAs were performed using the WNV-specific monoclonal antibody $3.1112 \mathrm{G}$ (Chemicon, Temecula, CA, USA) as previously described. ${ }^{22,23}$ The capacity of the test sera to prevent the binding of the WNV-specific monoclonal antibodies to the WNV antigen was compared to the blocking capacity of horse serum without antibodies to WNV. The sera were considered to be positive when the inhibition value was greater than $30 \%$ and to be ambiguous when the value was between $25 \%$ and $30 \%$. This assay which has previously been used for epidemiological studies of horses and birds ${ }^{24,25}$ has high specificity and sensitivity for WNV and has the advantage of being rapid, reproducible and less expensive than other methods. ${ }^{4}$

\section{Plaque reduction neutralisation tests (PRNTS)}

Positive and ambiguous samples were further evaluated using a PRNT $_{90}$, as previously described. ${ }^{26,27}$ PRNT $_{90} S_{\text {were }}$ performed with WNV and St. Louis encephalitis virus (SLEV). A serum sample was considered to contain antibodies to WNV if it significantly inhibited the binding of monoclonal antibody $3.1112 \mathrm{G}$ by ELISA and had a $90 \%$ PRNT $_{90}$ titre to WNV that was at least 4-fold greater than the corresponding SLEV PRNT90 titre. A serum sample was considered to contain antibodies to SLEV if the PRNT $_{90}$ titre to SLEV was at least 4-fold greater than the corresponding WNV titre. A serum sample was considered to have antibodies to a flavivirus of undetermined origin if it contained 
T. Ometto et al.

ELISA-detected or neutralising antibodies but did not meet the criteria for WNV or SLEV infection.

\section{Molecular tests}

In house one-step real-time RT-PCR

One-step real-time RT-PCR was performed using specific primers and a probe designed according to the sequence of gene $E$ (viral envelope) deposited in the GenBank database (Accession number: AY660002.1 - SEQ1F 5'-GCGATCTCTCCACCAAAGCT-3'; SEQ1R 5'-TGGGTCAGCACGTTTGTCAT-3'; SEQ1M1 FAM- CCATGGG AGAAGCTCACA 5 NFQ). For RNA extraction, a 5x MagMax $^{\mathrm{TM}}$ - 96 Viral Isolation Kit and an AgPath-ID ${ }^{\mathrm{TM}}$ One-Step RT-PCR Kit were used according to the manufacturer's instructions (Ambion, Inc. Austin, TX, USA). Real-time RT-PCR was performed in an ABI 7300 PCR System (Applied Biosystems, Foster City, CA, USA). All procedures were conducted in a Biosafety Level $3^{+}$Laboratory $\left(\mathrm{BSL}^{+}\right.$) at the Biomedical Institute at the University of São Paulo. The positive controls used were inactivated human plasma samples from blood donors, which were kindly provided by Dr Susan Stramer of the American Red Cross, NY, USA.

\section{Cobas $^{\circledR}$ TaqScreen West Nile Virus Test}

An automated real-time RT-PCR method (Cobas ${ }^{\circledR}$ TaqScreen West Nile Virus Test, Roche, Pleasanton, CA, USA) that is routinely used in the United States and Canada to screen blood donors was adopted to evaluate the serum and brain macerate samples. The analytical sensitivity of this method is reported to be 40 copies/ $\mathrm{mL}$ (95\% CI: $35.1-47.8$ copies $/ \mathrm{mL}$ ) for WNV lineage 1.28

\section{Results}

Of the 478 birds analysed, 5 (1.05\%) tested positive based on the WNV-specific blocking ELISA. Of the 678 equids analysed (517 horses, 156 mules and 5 donkeys), 13 (1.9\%) tested positive based on the WNV- specific blocking ELISA (Table 1). The results of the PRNT 90 did not confirm the flavivirus seropositivity for the 5 positive bird samples. Among the equid samples, the results of the PRNT 90 confirmed the flavivirus seropositivity for all 13 of the positive samples by specific blocking ELISA (WNV in 4 samples, SLEV in 5 samples and undifferentiated Flavivirus in 4 samples). The WNV and SLEV PRNT 90 titres ranged from 40 to 2560 (Table 1). Antibodies to SLEV were identified in horses in Teodoro Sampaio in 2002 and 2006 and in Juruena in Mato Grosso in 2009 (Figure 1). Equids with antibodies only to WNV were identified in Nova Brasilândia in Mato Grosso state in 2009 (1.8\%, 3 horses and 1 mule of 217 samples). The WNV-seropositive horses were between 5 and 8 years old.

All of the bird and equid samples (928 birds and 570 equids) tested by one-step real-time RT-PCR and the equid samples (422 serum and 63 brain) tested by automated real-time RT PCR were negative for the presence of WNV viral RNA.

\section{Discussion}

This is the largest molecular and serological screening of WNV in migratory birds and equines in Brazil. The spread of WNV throughout North America and periodic outbreaks of this virus in Eastern and Western Europe have increased worldwide interest in understanding the viral, host and ecological factors that result in WNV outbreaks. ${ }^{3}$ Although WNV is considered a public health problem, there have been no reports of human cases in Brazil. A recent molecular study analysed 8703 blood bank sera samples in 2011 in Amazon, São Paulo and Mato Grosso do Sul states, ${ }^{15}$ in locations close to those where we confirmed positivity for WNV antibodies in four equids. No positive results were obtained for the presence of WNV in the sera of healthy donors, ${ }^{15}$ despite the established prevalence of 1.49 (2003) and 0.44 (2004) out of 10000 donors in blood banks of the United States, a country where WNV is established. ${ }^{29}$

Following the introduction of WNV vaccinations for horses in the United States, the incidence of neuroinvasive disease in horses decreased from more than 14000 cases in 2002 to approximately 5100 in 2003, suggesting that the WNV vaccination had a substantial impact on equine health. ${ }^{1}$

As Brazil has no confirmed clinical cases of WNV, it is considered an exotic disease, and the Ministry of Agriculture and public health policies do not permit import or vaccine production for these types of diseases. Our work indicates a low prevalence of WNV antibodies in equids in Brazil, therefore, the vaccination of horses should be discussed from an economic standpoint with a model of free demand by the owners, as the cost-benefit of the vaccination may be greater than that of treating the animals, considering that Brazil has the largest herd of horses in South America. Based on serological evidence of WNV in birds and equines in Colombia, Venezuela and Argentina, 6,10,11 similar findings were anticipated in Brazil, which shares borders with these three countries.

Brazil has abundant circulating birds and mammals and also hosts a large and diverse population of mosquitoes, including Culex sp. and Aedes sp., which carry several flaviviruses and can produce important outbreaks, as has been observed with yellow fever and dengue. A large serological survey in Brazil between 2003 and 2004 did not demonstrate the presence of WNV antibodies in wild and domestic birds, ${ }^{7-9}$ although recent studies in the Pantanal area identified antibodies to WNV in five out of 168 equids in $2009^{2}$ and in three out of 38 equids in $2010 .^{12}$ However, these recent studies included small sample numbers, lacked a wide range of collection sites and sampled fewer species of animals than the current study; these study design differences have allowed us to better visualise the circulation of WNV in the country.

In our study, WNV seropositivity was identified in 2009 in equids ranging from 5 to 8 years old, providing a broad indication of the period of circulation of WNV (2004-2009) in this area. Positive WNV serology was not detected before 2009 (samples from 2002 and 2006 were negative), which could be due to the small number of samples or a reflection of the history of the dispersion of WNV from North to South America. The WNV equine seroprevalence in Nova Brasilândia was 1.8\%, which can be compared to the first identification of WNV in Yucatán, Mexico $(1.2 \%),{ }^{24}$ and to the seroprevalence determined in Pantanal $(3 \%){ }^{2}$ However, this seroprevalence is lower than that observed in Guadeloupe after the establishment of the WNV cycle there $(19.3 \%)^{30}$ or in Mexico in areas with a history of clinical encephalitis (22\%). ${ }^{31}$

In this study, we analysed two areas of Mato Grosso that were sampled during the same period with similar population sizes (217 and 218 equids), WNV circulation was only identified in Nova Brasilândia. This finding may be related to the specific 


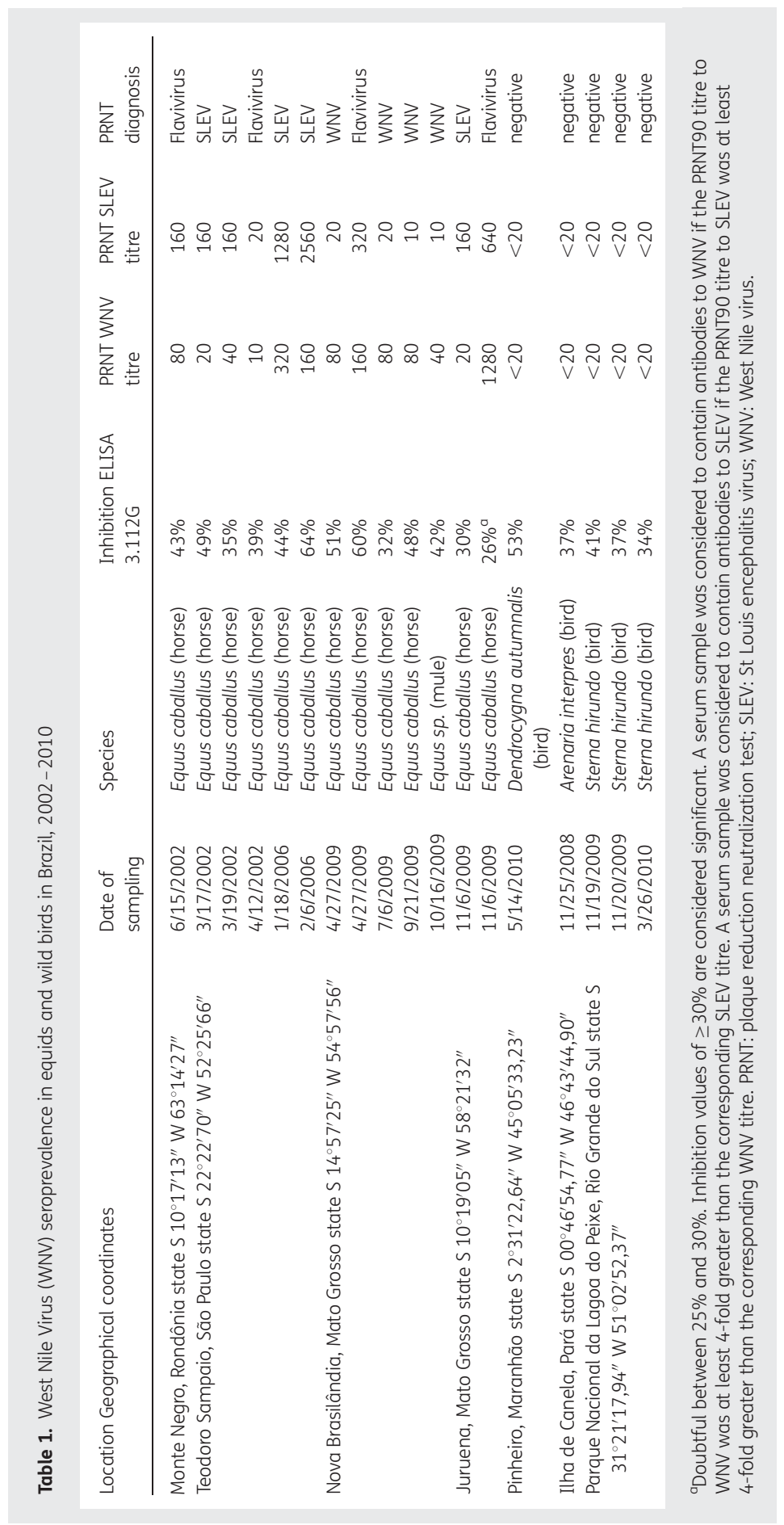


T. Ometto et al.

environmental and ecological characteristics of this area, such as the predominance of migratory birds from North America in the Pantanal region. ${ }^{32}$ This region is characterised by strong anthropogenic disturbance, including the recent expansion of farming, which involves human activities that are linked to deforestation These factors can interfere with the natural cycle of the virus and could increase the risk of WNV transmission to humans.

Although SLEV was not the focus of this study, the circulation of SLEV was detected in Teodoro Sampaio (São Paulo state) and Juruena (Mato Grosso state). The seroprevalence of SLEV was not assessed in this study because only samples that tested positive based on the results of WNV-specific blocking ELISA were further tested with the PRNT ${ }_{90}$. Some of the samples that were seropositive by the WNV-specific blocking ELISA were positive by PRNT $_{90}$ for SLEV at a higher titer than for WNV. If the PRNT results (gold standard) suggest that these samples are negative for WNV, considering the expected high specificity of the WNV-specific blocking ELISA, an alternative explanation could be that these samples were positive for both SLEV and WNV but that the PRNT test was not sensitive enough to detect WNV antibodies. The same reason could also indicate that the flavivirus positive samples could be in fact a co-infection with both WNV and another flavivirus.

The specific blocking ELISA used in our work uses MAb 3.112G, which can potentially discriminate between WNV and SLEV infections. ${ }^{23}$ Given the cross-reactivity among flaviviruses, particularly in areas such as South America, where multiple flaviviruses circulate, the specific blocking ELISA results are considered to be the more reliable ones even if PRNT 90 is still used as the reference assay for the specific diagnosis of WNV infection. Even though the diagnostic sensitivity of ELISA is 100\% compared to PRNT 90 , the specificity is only $79.5 \%{ }^{4}$ Using $\mathrm{PRNT}_{50}$ S in samples that were positive by ELISA and negative by PRNT $_{90}$ could have improved the sensitivity of the results. It is likely that we have underestimated the WNV circulation in Brazilian birds by using PRNT $_{90}$ because it has low sensitivity for the detection of antibodies in animals that have not been clinically infected, even though they may have been sub-clinically infected.

The limitations of this study include the failure to undertake the sampling of birds and equids in the same regions and at the same times, which makes it difficult to derive any solid ecological picture of what might have been occurring. Another limitation is related to the application of the PRNT 90 , which used only WNV and SLEV antigens. This methodology could lead to cross-reaction with other flaviviruses present in Brazil that are not commonly found in North America.

The direct molecular detection of WNV in equid and bird samples did not confirm the presence of WNV in the studied areas during any of the years of the study (2008, 2009 and 2010) but this is not surprising considering the short viraemia. WNV is therefore probably circulating in equids and birds, but as a sub-clinical infection due to the influence of other flaviviruses circulating in Brazil. It is likely that the WNV epidemic in Brazi behaves differently from that observed in North America: in Brazil, there is a greater diversity of flaviviruses, which increases the level of genetic resistance in South America. WNV could be circulating with the same pattern observed with other flaviviruses. ${ }^{2,12}$ These other flaviviruses infect equids and birds but do not cause clinical symptoms that are relevant to Brazilian health surveillance. Similar to other South American countries,
Brazil appears to have established a form of co-existence with WNV in which the virus can circulate, albeit at a low level in terms of pathogenicity, without causing any real problems.

The lack of evidence for WNV in birds in Brazil or the very low prevalence if the results are based on the WNV-specific blocking ELISA remains puzzling because several migratory species were evaluated, and seropositive birds have been prevalent for the last 5 years in countries neighbouring Brazil. Experimental infections in several bird species have indicated that viraemic levels remain high only for a short duration (a maximum of 7 days), making the introduction of WNV by long-distance migrators an unlikely event ${ }^{33}$ and corroborating the idea that the virus has spread through resident or short-distance migrant birds, thereby explaining the spread of the virus sequentially southward through the Americas and not directly by migrating birds from North America.

Our work used a large number of migratory bird samples from different stop-over points, and given our results, we believe that the input of WNV in Brazil is most likely due to birds resting at convenient 'staging posts' on their north-to-south journey. Those birds probably have gradually moved the virus to the south in stages, rather than clinically infected birds travelling the full distance. These data have been reinforced by the identification of WNV antibodies in equids only since 2009, along with other Brazilian studies that have also reported positive serology during the same period. $^{2,12}$ The introduction of WNV in Argentina occurred early via birds in January $2005 .{ }^{6}$ This information reinforces the idea of staging posts, as there are bird displacements between Brazil and Argentina (Figure 1), and quite intense contact occurs among these posts.

In relation to humans, there is a strong vaccination program for yellow fever in Brazil. Furthermore, the dengue virus is endemic in Brazil. Both the yellow fever virus and the four subtypes of the dengue virus can confer cross-immunity to other flaviviruses, resulting in WNV producing only sub-clinical infections. Similar correlations can be observed with equids with immunity to different flaviviruses due to constant exposure to these different viruses.

Considering the large population of reservoir birds and the abundance and diversity of mosquito species in Brazil, WNV may have become endemic in some states. The continuous evolution of WNV in North America ${ }^{34}$ and the possible consequences of WNV circulation in Brazil on public health, wild bird conservation and the economy emphasise the need to establish WNV surveillance and Brazilian WNV research programs to minimise possible damage to Brazilian society from the introduction of another lethal arbovirus in addition to those already established in the country.

Authors' contributions: TO, TL, ELD and JA conceived the study and designed the study protocol; TO, ELD, JA, DMA, GTC, RMM, SMAJ, MVP, ISN, PS, EV, EMSC, MCCSHL, AFDN, MSN, RFH, RR, AS, JS, MMMS, CP, DSB, MBL and LMAC carried out the sampling and critically revised the manuscript for intellectual content; TO, JA, JEL, RFH, MPG, MMMS, RA, JP, NV $T L$ and RL conducted the laboratory work, analysis and interpretation of the data. TO, TL, ELD, MMMS and JA drafted the manuscript; TO, TL, ELD, JA, DMA, JEL, MMMS and RL critically revised the manuscript for 
intellectual content. All authors read and approved the final manuscript. TO, ELD and TL are the guarantors of the paper.

Acknowledgments: We thank Nicolas Gaidet for mediating communication between CIRAD and the University of São Paulo.

Funding: This work was supported by the Fundação de Amparo à Pesquisa do Estado de São Paulo (FAPESP 2009/05994-9); Interreg IV Caraỉbe 'CaribVET' (Europe Project) and FEDER 2007-2013 'Risque en santé animale et végétale'.

Competing interests: None declared.

Ethical approval: This study was conducted in strict accordance with the recommendations of the Ethical Principles of Animal Experimentation adopted by the Brazilian Society of Laboratory Animal Science (SBCAL) and the animal protocol was approved by the Ethics Committee on Anima Experiments (EAEC) (Permit Number: 105, page 74, book 2). The equid sampling was approved by the Institutional Committee for Ethics in Anima Research of the Federal University of Mato Grosso No23108.017192/10-6 and the sampled birds were licensed by the Instituto Chico Mendes de Conservação da Biodiversidade (ICMBio/SISBIO).

\section{References}

1 Martina BEE, Koraka P, Osterhaus ADME. West Nile virus: is a vaccine needed? Curr Opin Investig Drugs 2010;11:139-46.

2 Pauvolid-Corrêa A, Morales MA, Levis S et al. Neutralising antibodies for West Nile virus in horses from Brazilian Pantanal. Mem Ins Oswaldo Cruz 2011:106:467-74.

3 Pesko KN, Ebel GD. West Nile virus population genetics and evolution. Infect Genet Evol 2012;12:181-90.

4 De Filette M, Ulbert S, Diamond M, Sanders NN. Recent progress in West Nile virus diagnosis and vaccination. Vet Res 2012;43:16.

5 Komar N, Clark GG. West Nile activity in Latin America and the Caribbean. Rev Panam Salud Publica 2006;19:112-7.

6 Adrián Diaz L, Komar N, Visintin A et al. West Nile virus in birds, Argentina. Emerg Infect Dis 2008;14:689-91.

7 Araujo FAA, Vianna RST, Andrade Filho GV et al. Primeiro inquérito sorológico em aves migratórias e nativas do Parque Nacional da Lagoa do Peixe/RS para detecção do vírus do Nilo Ocidental. Bo Eletron Epidemiol 2003;1:3-12.

8 Araujo FAA, Wada MY, Silva EV et al. Segundo inquérito sorológico em aves migratórias e residentes do Parque Nacional da Lagoa do Peixe/RS para detecção do vírus do Nilo Ocidental e outros vírus. Bol Eletron Epidemiol 2004;5:1-8

9 Araujo FAA, Vianna RST, Andrade Filho GV et al. Inquérito sorológico em aves migratórias e residentes de Galinhos/RN para detecção do vírus da Febre do Nilo Ocidental e outros vírus. Bol Eletron Epidemiol 2004;2:1-12.

10 Mattar S, Edwards E, Laguado J et al. West Nile virus antibodies in Colombian Horses. Emerg Infect Dis 2005;11:1497-8.

11 Bosch I, Herrera F, Navarro JC et al. West Nile virus, Venezuela. Emerg Infect Dis 2007;13:651-3.

12 Melandri V, Guimarães AÉ, Komar N et al. Serological detection of West Nile virus in horses and chicken from Pantanal, Brazil. Mem Inst Oswaldo Cruz 2012;107:1073-5.

13 Morales MA, Barrandeuguy M, Fabbri C et al. West Nile virus isolation from equines in Argentina. Emerg Infect Dis 2006;12:1559-61.
14 Domingues RB, Teixeira AL. Management of acute viral encephalitis in Brazil. Braz J Infect Dis 2009;13:433-9.

15 Levi JE, Geraldi MP, Torres KL et al. Investigação molecular da presença do virus do Oeste do Nilo em doadores de sangue e pacientes de três regiões brasileiras. Revista Brasileira de Hematologia e Hemoterapia 2011;33:399.

16 Rosa JFST, Rosa APAT, Vasconcelos PFC et al. Arboviruses isolated in the Evandro Chagas Institute, including some described for the first time in the Brazilian Amazon region, their known hosts, and their pathology for man. In: Rosa APAT, Vasconcelos PFC, Rosa JFCT (Editors). An Overview of Arbovirology in Brazil and Neighbouring Countries. Belém, Brazil: Instituto Evandra Chagas 1998: p. 19-31.

17 Ministério do Meio Ambiente. Brazilian biomes. Brasilia, Brazil. http:// www.brasil.gov.br/sobre/environment/geography [accessed 15 May 2013].

18 Ministério do Agicultura, Pecuária e Abastecimento. Equídeos. Brasília, Brazil. http://www.agricultura.gov.br/animal/especies/equideos [accessed 20 May 2013].

19 Carmargo LMA, Moura MM, Engracia $V$ et al. A rural community in Brazilian Western Amazonian region: Some demographic and epidemiological patterns. Mem Inst Oswaldo Cruz 2002;97:193-5.

20 Alessi CAC, Galati EAB, Alves JR, Corbett CEP. American cutaneous leishmaniasis in the Pontal of Paranapanema-SP, Brazil: ecological and entomological aspects. Rev Inst Med Trop 2009;51: 277-82.

21 Rodrigues RC, Azevedo-Júnior SM, Larrazábal ME, Araujo HFP. Temporal variations of body mass and plumage in Arenaria interpres (Aves: Scolopacidae) along the Brazilian coast. Zoologia 2009;26:386-90.

22 Blitvich BJ, Bowen RA, Marlenee NL et al. Epitope-blocking enzymelinked immunosorbent assays for detection of West Nile virus antibodies in domestic mammals. J Clin Microbiol 2003;41:2676-9.

23 Blitvich BJ, Marlenee NL, Hall RA et al. Epitope-blocking enzyme-linked immunosorbent assays for the detection of serum antibodies to West Nile virus in multiple avian species. J Clin Microbiol 2003;41:1041-7.

24 Loroño-Pino MA, Blitvich BJ, Farfán-Ale JA et al. Serologic evidence of West Nile virus infection in horses, Yucatan State, Mexico. Emerg Infect Dis 2003;9: 857-9.

25 Blitvich BJ, Fernadez-Salas I, Contreras-Cordero JF et al. Serologic evidence of West Nile virus infection in horses, Coahuila State, Mexico. Emerg Infect Dis 2003;9:853-6.

26 Beaty B, Calisher CH, Shope RE. Arboviruses. In: Lennette EH, Lennette DA, Lennette ET (Editors). Diagnostic Procedures for Viral, Rickettsial and Chlamydial Infections. 7th ed. Washington, DC: American Public Health Association. 1995: p. 189-212.

27 Fernández-Salas I, Contreras-Cordero JF, Blitvich BJ et al. Serologic evidence of West Nile Virus infection in birds, Tamaulipas State, México. Vector Borne Zoonotic Dis. 2003;3:209-13.

28 Pai A, Kleinman S, Malhotra K et al. Performance characteristics of the Food and Drug Administration - licensed Roche Cobas TaqScreen West Nile virus assay. Transfusion 2008;48:2184-9.

29 Stramer SL, Fang CT, Foster GA et al. West Nile virus among blood donors in the United States, 2003 and 2004. N Engl J Med 2005;353:451-9.

30 Lefrançois T, Blitvich B, Pradel J et al. West Nile virus surveillance, Guadeloupe, 2003-2004. Emerg Infect Dis 2005;11:1100-3.

31 Estrada-Franco JG, Navarro-Lopez R, Beasley DW et al. West Nile virus in Mexico: evidence of widespread circulation since July 2002. Emerg Infect Dis 2003;9:1604-7. 
T. Ometto et al.

32 Nunes AP, Tomas WM. Embrapa Pantanal. Aves migratórias e nômades ocorrentes no pantanal. http://www.cpap.embrapa.br/publicacoes/ online/Livro033.pdf [accessed 10 June 2008].

33 Koopmans M, Martina B, Reusken C, Van Maanen K. West Nile virus in Europe: waiting for the start of epidemic? In: Taakken W, Knols BG
(Editors). Emerging Pests and Vector-Borne Diseases in Europe. Volume 1. Wageningen, The Netherlands: Wageningen Academic Publishers. 2007: pp. 123-52.

34 McMullen AR, May FJ, Li L et al. Evolution of new genotype of West Nile virus in North America. Emerg Infect Dis 2011;17:785-93. 